Portland State University

PDXScholar

Spring 4-14-2013

\title{
Assessment of Solar Photovoltaic Technologies Using Multiple Perspectives and Hierarchical Decision Modeling
}

Nasir Jamil Sheikh

Portland State University

Follow this and additional works at: https://pdxscholar.library.pdx.edu/open_access_etds

Part of the Energy Systems Commons, Environmental Engineering Commons, and the Industrial Technology Commons

Let us know how access to this document benefits you.

\section{Recommended Citation}

Sheikh, Nasir Jamil, "Assessment of Solar Photovoltaic Technologies Using Multiple Perspectives and Hierarchical Decision Modeling" (2013). Dissertations and Theses. Paper 978.

https://doi.org/10.15760/etd.978

This Dissertation is brought to you for free and open access. It has been accepted for inclusion in Dissertations and Theses by an authorized administrator of PDXScholar. Please contact us if we can make this document more accessible: pdxscholar@pdx.edu. 
Assessment of Solar Photovoltaic Technologies Using Multiple Perspectives and Hierarchical Decision Modeling

by

Nasir Jamil Sheikh

A dissertation submitted in partial fulfillment of the requirements for the degree of

Doctor of Philosophy
in
Technology Management

Dissertation Committee:

Dundar F. Kocaoglu, Chair

Tugrul U. Daim

Robert D. Dryden

Loren Lutzenhiser

Portland State University 2013 


\begin{abstract}
The objective of this research is to build a decision model for a comprehensive assessment of solar photovoltaic technologies using multiple perspectives. These perspectives include: social, technological, economic, environmental, and political (STEEP) with each perspective consisting of multiple criteria. Hierarchical decision modeling and expert judgment quantification are used to provide the relative ranking of the perspectives and criteria. Such modeling is effective in addressing technology evaluations with competing and contrasting perspectives and criteria where both quantitative and qualitative measurements are represented. The model is then operationalized by constructing desirability functions for each criterion. The combined results provide an overall numerical score for each technology under consideration as well as criteria desirability gaps. This model is useful for assessing photovoltaic technologies from varying worldviews such as the electric utility worldview, the photovoltaic manufacturer's worldview, or the national policy worldview. This model can also provide guidance to decision makers and practitioners on areas of improvement for a selected technology. The research utilizes the electric utility worldview as a case study.
\end{abstract}




\section{DEDICATION}

To my beloved wife, Laila and children, Nadia, Omar, and Noor, who are my strength and inspiration.

In memory of my parents, Sadaqat and Muhammed Jamil Sheikh, who instilled in me my lifelong values and the desire for education and learning.

In memory of my father-in-law, Air Marshal Sultan Muhammed Dutta, who was highly accomplished and yet considered his family his highest achievement. 


\section{ACKNOWLEDGEMENTS}

I express my deep gratitude to the main force behind this dissertation, Dr. Dundar Kocaoglu, my mentor, my advisor, and the chairman of my dissertation committee. His wisdom and vision has helped me stay focused and on track. His constant support and guidance made this journey fulfilling and rewarding.

I am grateful to Dr. Tugrul Daim, who provided support, guidance, and encouragement during this undertaking. He was also instrumental in my initial publications in journals and books.

I am thankful to professors Dr. Dundar Kocaoglu, Dr. Tugrul Daim, Dr. Robert Dryden and Dr. Loren Lutzenhiser for their constructive criticism, advice, and counsel in their capacity as members of my PhD dissertation committee.

I want to thank the Engineering and Technology Management Department staff Shawn Wall, Ann White, and Liono Setiowijoso for their welcoming and always-ready-to-help support.

It is with great joy that I thank my daughters Nadia and Noor Sheikh for their editorial review of my dissertation drafts. 
A special thanks to Saleem Salahuddin of UC Davis who provided invaluable assistance in developing customized web-based research instruments to test their viability.

I want to acknowledge the Research Institute for Sustainable Energy (RISE), Department of Engineering and Technology Management, Portland State University, Oregon for the support of this research and in particular, Yasser Alizadeh and Ibrahim Iskin for their initial work.

I want to thank all the Engineering and Technology Management Department professors and fellow graduate students who made my Portland State University experience memorable and gratifying. 


\section{TABLE OF CONTENTS}

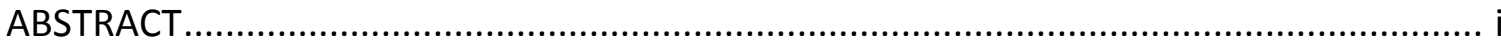

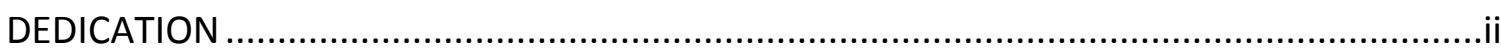

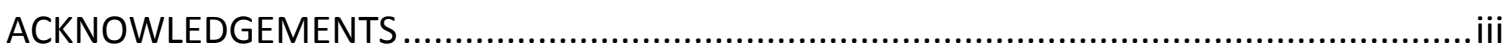

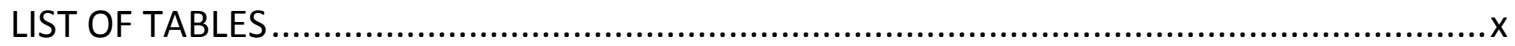

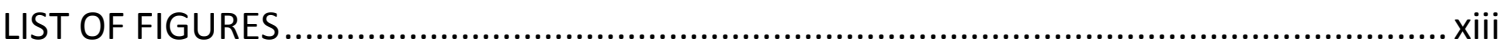

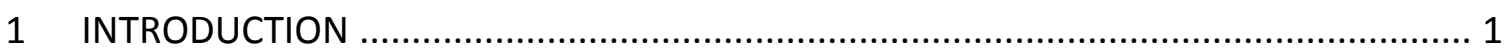

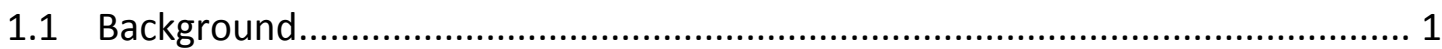

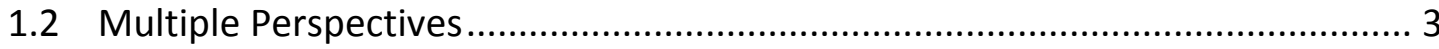

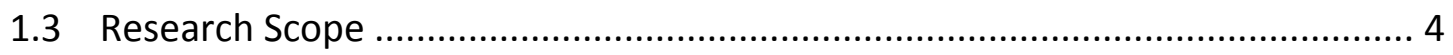

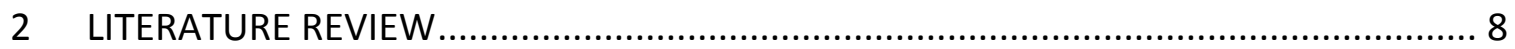

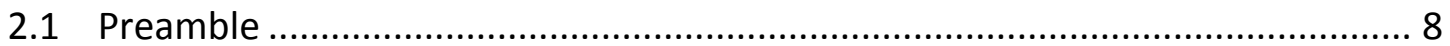

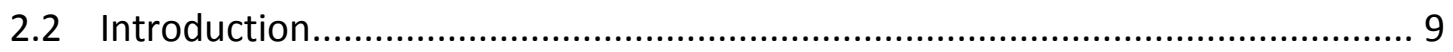

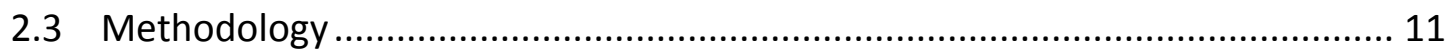

2.4 Solar Photovoltaic Renewable Energy ..................................................... 13

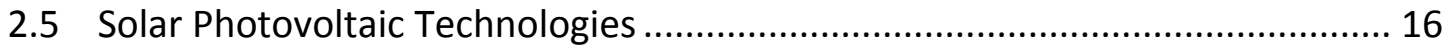

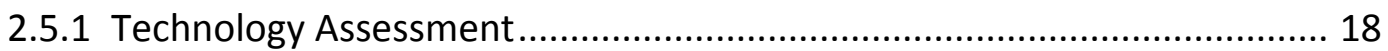

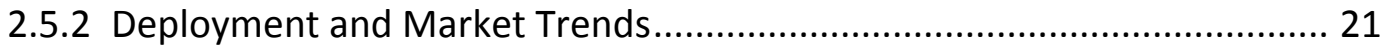

2.6 Multiple Perspectives, Decision Making, and Technology Assessment............ 23

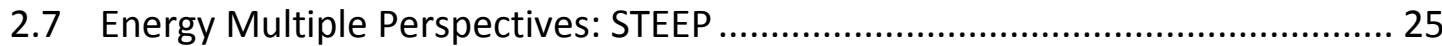

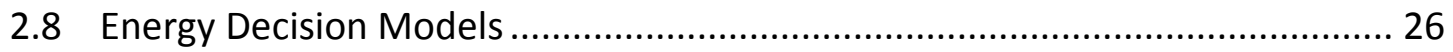




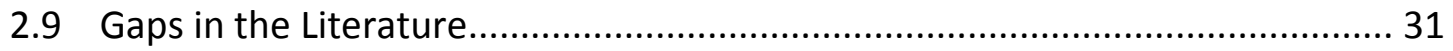

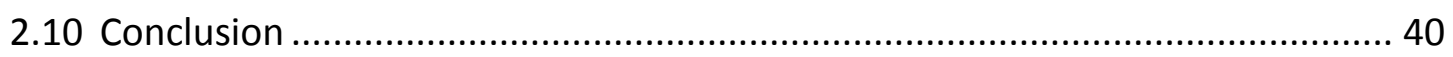

2.10.1 Literature Review: Addressing the Main Objective........................ 40

2.10.2 Building Criteria Sets By Perspective ........................................ 40

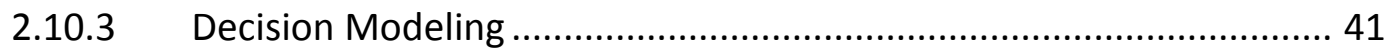

2.10.4 Research Gaps .................................................................... 41

2.10.5 Proposed Research ............................................................. 43

3 VALUE OF MULTIPLE PERSPECTIVES: ILLUSTRATIONS ...................................... 45

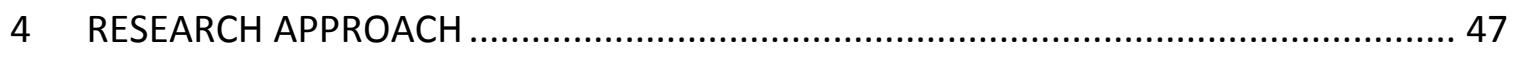

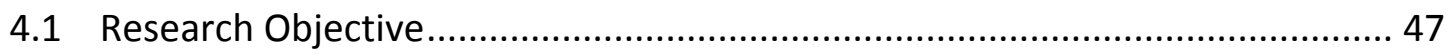

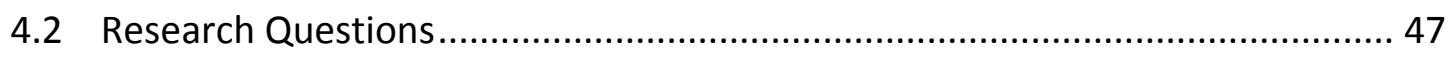

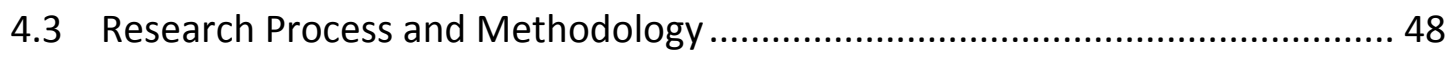

4.3.1 Stage 1: Building of the Hierarchical Decision Model.............................. 49

4.3.2 Stage 2: Expert Panel Selection ....................................................... 53

4.3.3 Stage 3: Data Acquisition and Validation............................................ 54

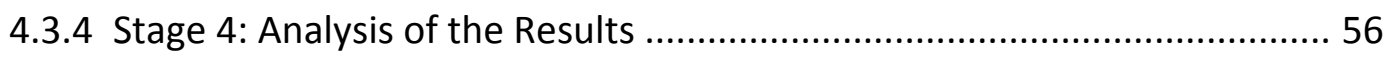

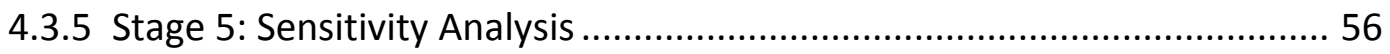

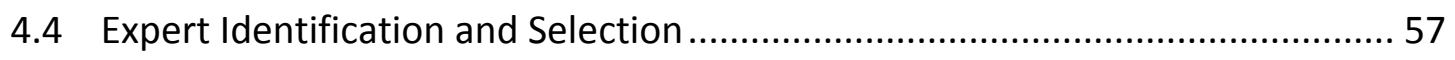

4.4.1 Eliciting Expert Judgment: Background ......................................... 57 
4.4.2 Identifying Experts for the Panel

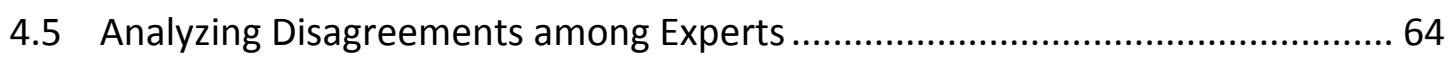

4.5.1 Disagreements among Experts: Background ..................................... 64

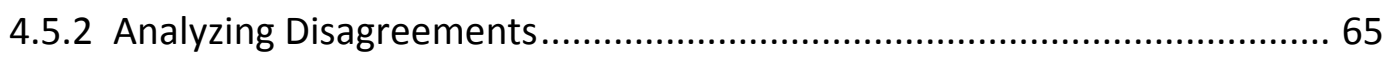

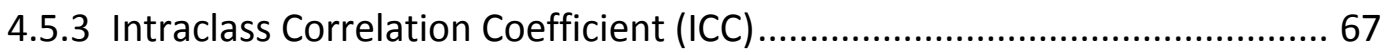

4.5.4 F-Test with Hypothesis Testing ................................................... 70

4.5.5 Identification of Experts in Disagreement ............................................ 73

4.6 Generalized Hierarchical Decision Model for Technology Values ..................... 77

4.6.1 Hierarchical Decision Modeling for Renewable Energy Technology

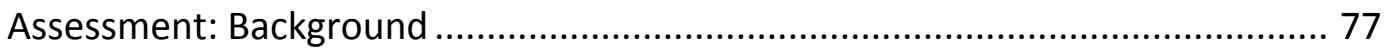

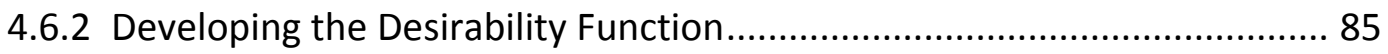

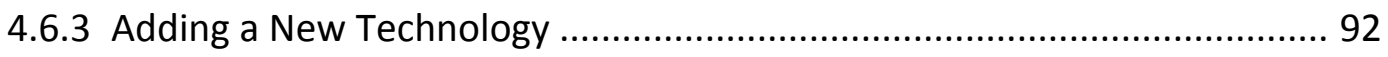

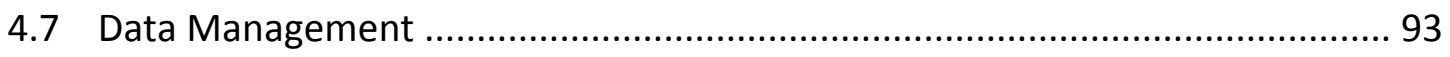

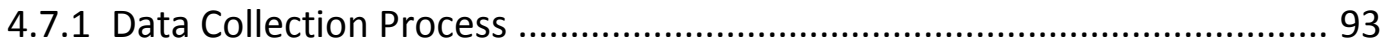

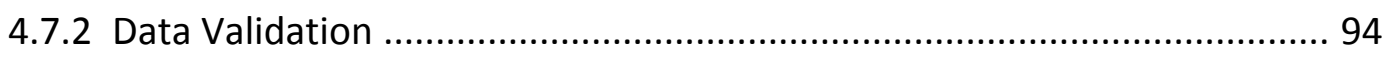

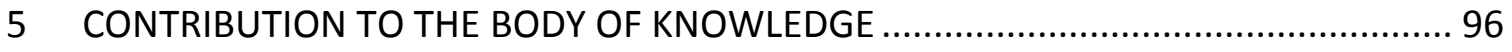

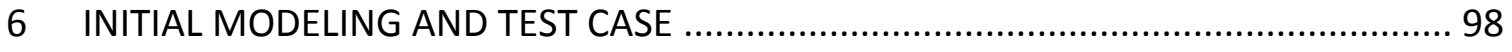

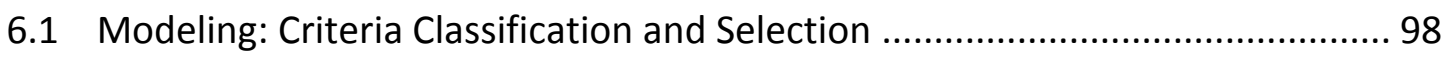

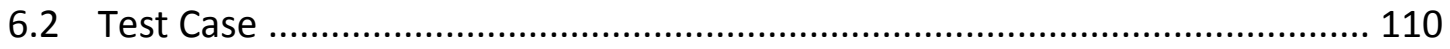


6.2.1 Judgment Quantification Instrument for Expert Panel

6.2.2 Results and Analysis

6.2.3 Initial Findings

7 RESEARCH RESULTS 119

7.1 Stage 1: Building of the Hierarchical Decision Model

7.2 Stage 2: Expert Panel Selection....... 128

7.3 Stage 3: Data Acquisition and Validation 132

7.3.1 Ranking of STEEP Perspectives: Electric Utility Worldview 132

7.3.2 Ranking of Social Perspective Criteria 133

7.3.3 Ranking of Technical Perspective Criteria. 135

7.3.4 Ranking of Economic Perspective Criteria

7.3.5 Ranking of Environmental Perspective Criteria 138

7.3.6 Ranking of Political Perspective Criteria 140

7.3.7 STEEP Desirability Functions 142

7.3.8 STEEP Desirability Values of Candidate PV Technologies 150

7.3.9 Calculated Technology Values of Candidate PV Technologies 152

7.3.10 Improvements Needed to Make OPV Top Ranked Technology........ 154

7.3.11 Result Validation and Analysis 155

7.3.12 Analysis of Results with Social Criteria and Expert Disagreements .. 159 viii 
7.3.13 Sensitivity Analysis

8 RESEARCH ASSUMPTIONS AND LIMITATIONS............................................... 165

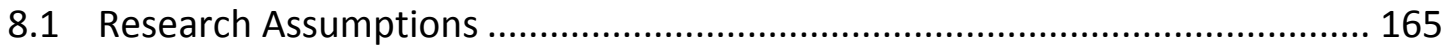

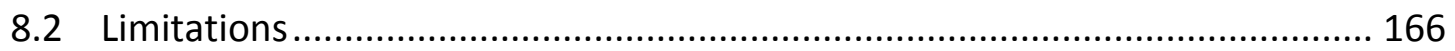

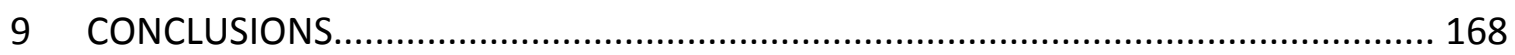

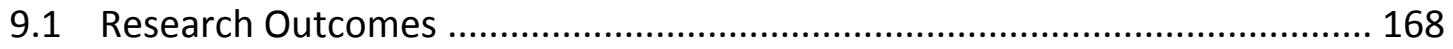

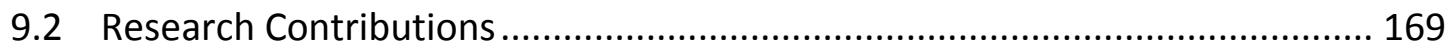

9.2.1 Contribution 1: Contribution to the Body of Knowledge ........................ 169

9.2.2 Contribution 2: Gaps in Research Identified....................................... 169

9.2.3 Contribution 3: Hierarchical Decision Model for Assessment of PV

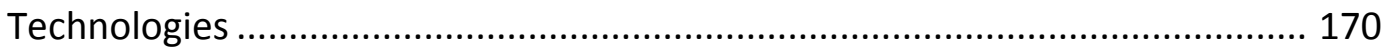

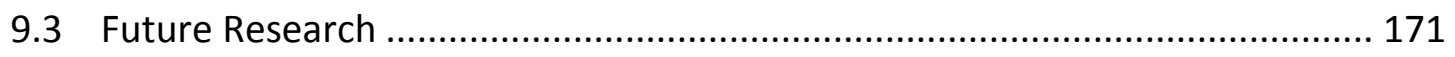

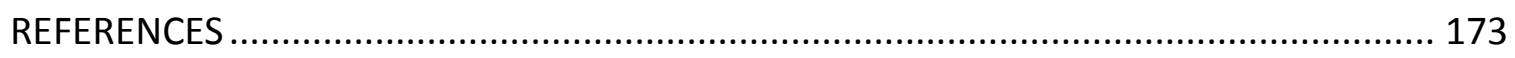

APPENDIX A: INITIAL JUDGMENT QUANTIFICATION INSTRUMENT ............................. 182

APPENDIX B: INITIAL MULTIPLE CRITERIA AND FACTORS FOR STEEP PERSPECTIVES .... 189

APPENDIX C: STEEP DECISION MODEL CRITERIA VALIDATION INSTRUMENT ................ 194

APPENDIX D: STEEP DESIRABILITY FUNCTIONS INSTRUMENT ..................................... 197 


\section{LIST OF TABLES}

Table 1: Number of Papers Reviewed by Theme........................................................ 13

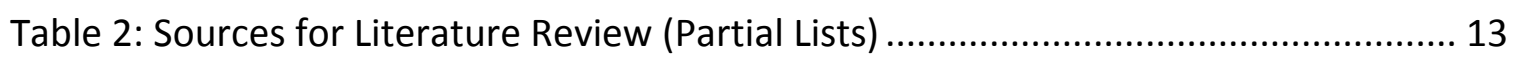

Table 3: Comparison of Critical Elements of Several Advanced MCDA Methods: MAUT,

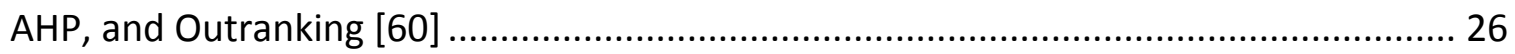

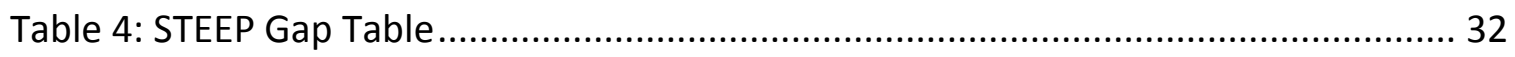

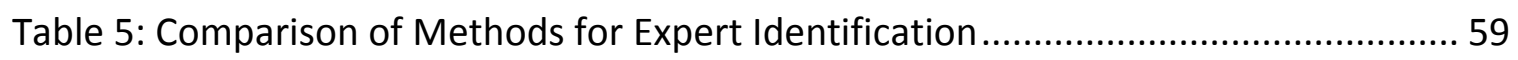

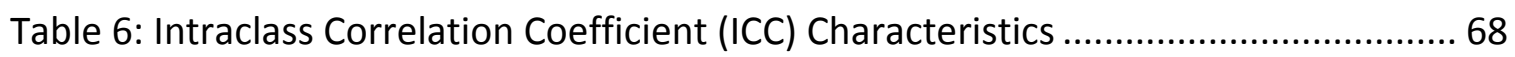

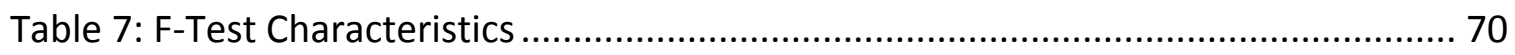

Table 8: Deriving Sums and Means for ICC Example - Intermediate Step ..................... 71

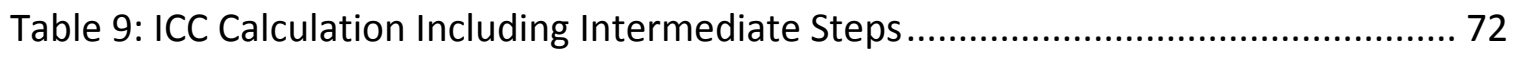

Table 10: F-Test Hypothesis Testing Calculations ......................................................... 73

Table 11: F-Test: F-Critical Calculations and Conclusion of Expert Agreement............... 73

Table 12: Determining Priorities and Contributions at each HDM Level ....................... 78

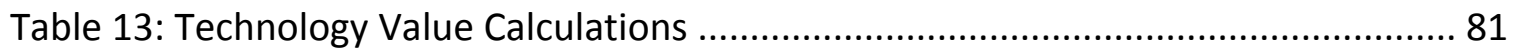

Table 14: Measurements to Determine Relative Value of Perspectives, Criteria, Factors,

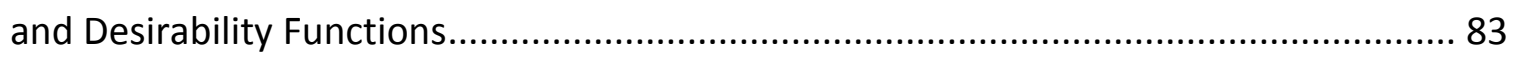

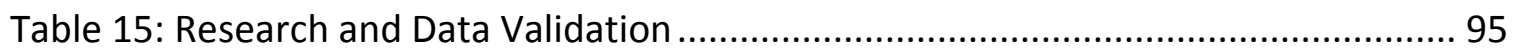

Table 16: Multiple Criteria for Each Steep Perspective (Based on [15] And Expert

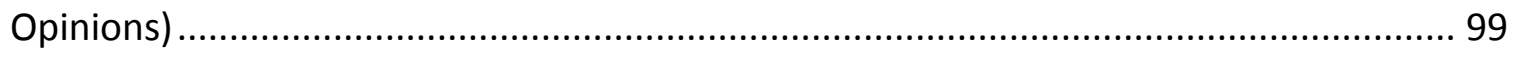

Table 17: Highest and Lowest Criteria in Relative Importance to Each Perspective...... 117 
Table 18: Public Perception Criteria and its Factors

Table 19: Final STEEP Criteria

Table 20: Qualifications and Positions of the Experts

Table 21: Number of Experts for Each Panel Type

Table 22: Number of Experts for Criteria Desirability Functions.....

Table 23: Relative Ranking of Perspectives in Fulfilling the Mission

Table 24: Relative Ranking of the Perspectives in Comparison to the Best

Table 25: Relative Ranking of Social Criteria

Table 26: Relative Ranking of Technical Criteria 136

Table 27: Relative Ranking of Economic Criteria 137

Table 28: Relative Ranking of Environmental Criteria 139

Table 29: Relative Ranking of Political Criteria 141

Table 30: Desirability Values of Candidate PV Technologies: Social Criteria 150

Table 31: Desirability Values of Candidate PV Technologies: Technical Criteria. 151

Table 32: Desirability Values of Candidate PV Technologies: Economic Criteria 151

Table 33: Desirability Values of Candidate PV Technologies: Environmental Criteria ... 152

Table 34: Desirability Values of Candidate PV Technologies: Political Criteria 152

Table 35: Technology Values for Five Candidate Technologies: c-Si, a-Si, CIGS, CdTe, and OPV 153

Table 36: Technology Value Comparison with Respect to the Best Technology 153

Table 37: Improvements Needed for OPV to be Top Ranked 154 
Table 38: Social Criteria Relative Values for Expert Groups 2 - 5

Table 39: Recalculating PV Technology Values with Expert Groups 2 - 5 for Social Criteria

Table 40: Sensitivity Analysis with a Dominant STEEP Perspective. 162 


\section{LIST OF FIGURES}

Figure 1: Three Literature Review Themes for Comprehensive PV Technology

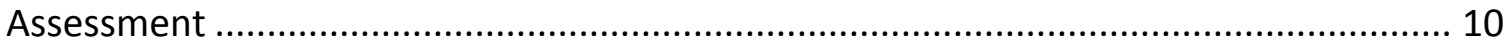

Figure 2: The Literature Review Process............................................................. 12

Figure 3: Global Solar PV Electricity Production by End-Use Sector 2010-2050 (2009) [17]

Figure 4: Worldwide Distribution of PV Electricity [18] .......................................... 15

Figure 5: NREL compilation of best research solar cell efficiencies [21] ....................... 17

Figure 6: Example - Photovoltaic Technologies Assessment Using Decision Analysis

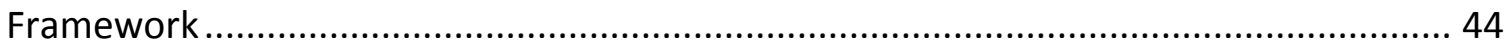

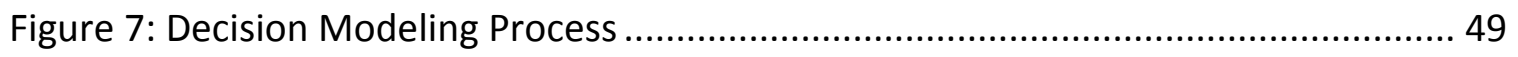

Figure 8: An Initial Hierarchical Decision Model Framework ........................................ 52

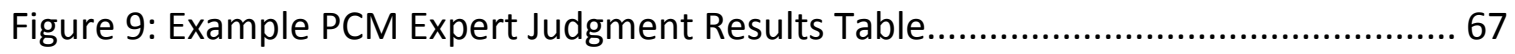

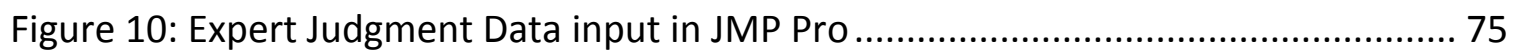

Figure 11: Hierarchical Cluster Analysis (HCA)/Dendrogram Example in JMP Pro........... 75

Figure 12: Generalized Hierarchical Decision Model for Renewable Energy Assessment of

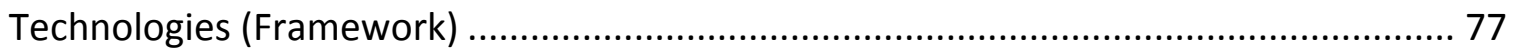

Figure 13: Hierarchical Decision Model for Assessing Technologies.............................. 80

Figure 14: Hierarchical Decision Model for Assessing Technologies with No Factors ..... 82

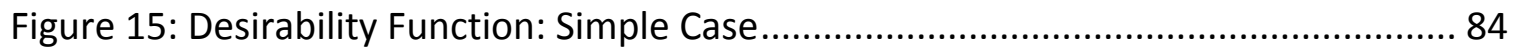


Figure 16: Desirability Function Generic Example Using Direct Plotting Method: Generic

Illustration 87

Figure 17: Desirability Function Example Using Pairwise Comparison Method: Generic Illustration 88

Figure 18: Standard Gamble Example - Reference Gamble. 90

Figure 19: Preference Function Example Using Standard Gamble Method - For a Specific

Risk Profile. 91

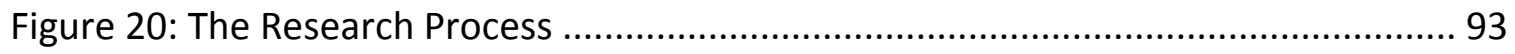

Figure 21: Sample Judgment Quantification Instrument Pages ............................... 113

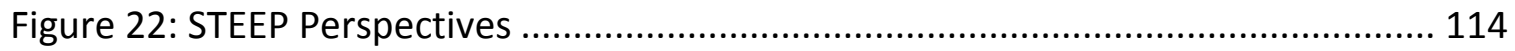

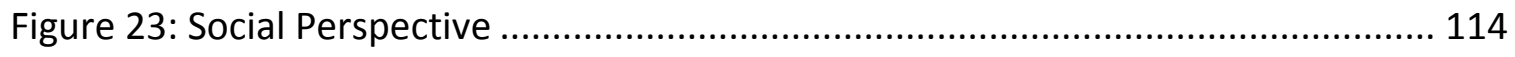

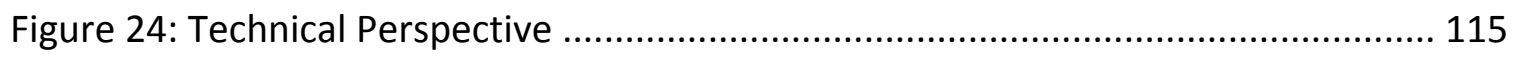

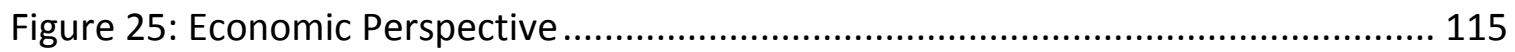

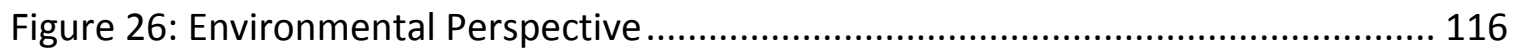

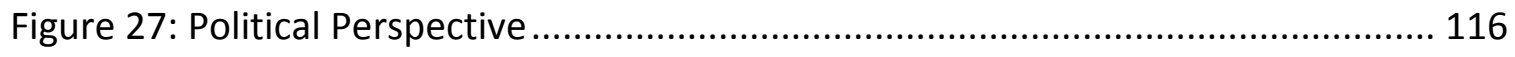

Figure 28: Intermediate Hierarchical Decision Model Reduced to 33 Criteria and No

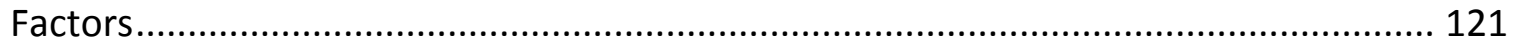

Figure 29: Final Hierarchical Decision Model with 39 Criteria and No Factors ............. 122

Figure 30: Desirability Functions for Social Criteria............................................... 143

Figure 31: Desirability Functions for Technical Criteria ............................................. 145

Figure 32: Desirability Functions for Economic Criteria ......................................... 147 
Figure 33: Desirability Functions for Environmental Criteria

Figure 34: Desirability Functions for Political Criteria ........................................... 150

Figure 35: Technology Values for Five Candidate Technologies: c-Si, a-Si, CIGS, CdTe, and

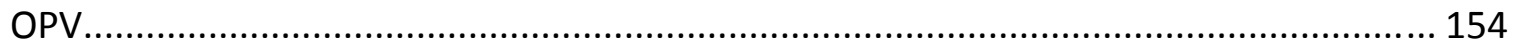

Figure 36: Cluster Analysis of Social Criteria Rankings by Experts ............................. 160 


\section{INTRODUCTION}

\subsection{Background}

Due to increasing awareness of the detrimental effects of fossil fuels and their associated costs for electricity generation, the global trend is to invest in renewable energy sources such as solar, wind, biomass, geothermal, and wave. International and national policies are being implemented to incentivize and support the growth of renewable energy for a variety of reasons including climate change mitigation, fossil fuel pricing, societal demand, and renewable energy pricing heading towards grid parity [1-4].

Energy technology and deployment planning efforts include energy sourcing and the evaluation of energy conversion devices to meet the desired energy demands in a relatively optimal fashion. In today's world an energy planning decision involves a complex process of weighing and balancing diverse socio-political, technical, economic, and environmental perspectives with spatial and temporal considerations. This balancing act is becoming increasingly important as people become more aware of their rights as responsible citizens and their responsibilities as protectors of the social and natural environments. These perspectives are usually represented as multiple criteria (and may include sub-criteria) and may represent conflicting or opposing objectives. These criteria may sometimes be difficult to define and may include quantitative and qualitative sub-criteria or factors. Decision making around 
energy planning using multiple criteria analysis has been in use for over forty years [57]. Up to the 1970s, the most popular criteria were technology and cost. However, in the 1980s environmental considerations also became important. Later on, social aspects were incorporated in the decision analysis and planning process. Political criteria also began to be explicitly recognized through public policies and regulations. Adding to the complexity, renewable energy sources brought further sets of nuances and criteria. This also broadened the scope of evaluations and decision making.

Technology options too have increased significantly due to the increase in research and development (R\&D) in renewable energy technologies [8-10]. Public and private sector decision makers now need to assess technologies with respect to a whole range of perspectives and criteria. Better and more comprehensive methods are needed for decisions on renewable energy because the effect of such technology decisions will be felt for the life of the technology, which could easily exceed fifteen to twenty years.

The traditional approach of applying technological and economics-based methods is still fundamental and needed for the assessment process; however, criteria related to environmental, social, and political perspectives are becoming more important due to public sentiment and regulations. 


\subsection{Multiple Perspectives}

Harold A. Linstone laid the foundation for decision making and evaluating technologies using multiple perspectives and has produced seminal research in this area [11-14]. The fundamental concepts can be expanded to be applicable for renewable energy technologies, systems, and processes.

Today, renewable energy generation and technologies are being considered from multiple perspectives based on priorities and the decision maker's position. Criteria such as economic feasibility, supply demand relationships, environmental impact of any energy source, government regulations, and national security with the threat of shortages are becoming increasingly important in such decisions. Energy generation needs are now being considered more comprehensively in order to capture the multiple perspectives that drive and impact decisions.

In this research the renewable energy multiple perspectives are referred to as: social, technological, economic, environmental, and political (STEEP). These perspectives are composed of multiple criteria and each criteria in-turn is composed of multiple subcriteria (and may be referred to as "factors" for easy distinction). The criteria that relate to each perspective can be stated as follows:

- Social Perspective. Criteria that impact society-positively or negatively.

- Technological Perspective. Criteria that relate to technical performance. 
- Economic Perspective. Criteria that are indicated by cost of technology diffusion, market adoption, and life-cycle costs ("push-pull-sustenance").

- Environmental Perspective. Criteria that have an impact on the environment and the earth's natural ecosystems.

- Political Perspective. Criteria that make up political motivation, policies and regulations, market special interests, compliance, and security.

Despite the growing need for multiple perspectives in energy planning, a literature review indicates that studies and findings are limited in scope, cover broad criteria (and not specifics related to renewable energy), have limited capability for operationalization, are project or policy oriented, and have almost no reference to specific renewable energy technologies (especially solar photovoltaic technologies) [15]. Considering all five perspectives for decision modeling and technology assessments in the area of renewable energy generation is a new area of research that can prove to be more effective than using their subset.

\subsection{Research Scope}

An assessment of renewable energy technologies is a complex decision problem since there are multiple perspectives (such as the five perspectives referred to earlier) to consider. This complex decision problem can be decomposed as a hierarchical decision model (HDM) where different perspectives and their associated criteria can 
be prioritized and ranked. The evaluation of various levels of criteria can then be applied to address the question, "In the judgment of the decision makers and experts which perspective or criteria are more important than others?" For the purpose of this research, the specific focus is on solar photovoltaic energy technologies.

This is part of an ongoing research at the Research Institute for Sustainable Energy (RISE), Department of Engineering and Technology Management, Portland State University, Oregon. The program was founded by Dundar Kocaoglu and Tugrul Daim of the same department and includes comprehensive assessment of energy technologies and applications considering the five perspectives stated above: social, technical, economic, environmental, and political. The program involves the use of HDM for evaluation of criteria, use of desirability functions (similar to utility function) for evaluation of factors, and then technology characterization as a composite of perspectives, criteria, and factors.

This research is built upon the interest of the author to develop a framework for a comprehensive assessment of renewable energy technologies that have broad societal implications. The approach is to evaluate the technologies from multiple perspectives including social, technical, economic, environmental, and political (STEEP) and their associated criteria. The criteria may be quantitative or qualitative. Such a framework addresses the following questions: 
- Which technology is ranked best when considered from the five STEEP perspectives?

- How can a technology be evaluated with competing and contrasting perspectives, criteria, and factors where both quantitative and qualitative measurements are represented?

- How can the decision makers with different worldviews be assisted to rank the best technology? The decision makers' worldview may be defined as the overall perspective from which the decision making body sets priorities. The worldviews may include: policy making, technology supplier, energy/electric utility, and commercialization of emerging technology.

The objective of this research is to develop a comprehensive method to evaluate solar PV technologies under the STEEP perspectives.

This research will enable decision makers to make decisions in a complex environment with many competing criteria and perspectives. The need for PV technology assessment may arise from different considerations such as national policy, deployment, development, and research.

The research questions address the three gaps found in the literature. These can be stated as: 
- How can a technology assessment model be built, including the five broad perspectives together with the robust set of criteria and factors that will enable the model to be operationalized?

- Can this model be standardized as a decision model that will enable researchers and practitioners to enable a broad variety of renewable and/or solar technologies to be evaluated?

- How can the following stakeholders be assisted to make better decisions on technology evaluation and commercialization:
a. Policy makers
b. Technology suppliers
c. Energy utilities
d. Universities, research institutes, and national laboratories 


\section{LITERATURE REVIEW}

\section{$2.1 \quad$ Preamble}

The literature review completed as an independent study revealed gaps in the comprehensive assessment of energy (and in particular solar) technology and that filling these gaps may improve the overall assessment with respect to the five STEEP perspectives. The following is the abstract of the resulting paper which was published in the PICMET'11 Conference proceedings:

"Renewable energy generation technologies are complex systems that have wideranging implications in their production and deployment. Using multiple perspectives such as social, technological, economic, environmental, and political (STEEP) and their decomposition into multiple criteria or indicators provide a broader yet explicit assessment of the technology under consideration. An effective method of determining the relative importance of a criterion with respect to others is by hierarchical decision modeling and expert judgment quantification instruments. These combined approaches can improve decision making for technology assessment and selection. This paper describes the approach and presents an example for photovoltaic solar technologies."[15] 


\subsection{Introduction}

Current global trends reflect the increasing significance of renewable energy relative to conventional energy sources such as coal, gas, oil, and nuclear. In fact renewable energy has reached a tipping point and its share of the energy supply is showing signs of significant growth albeit from a low baseline. International, national, and regional policies are being enacted to incent and support the growth for a variety of reasons including climate change mitigation, fossil fuel pricing, societal demand, and renewable energy pricing heading towards grid parity [1-3], [16].

Increased research and development (R\&D) in renewable energy technologies is leading to the proliferation of technology options [8-10]. Decision making around technology development, deployment, and promotion by governments and companies is becoming increasingly complex and confusing due increasing awareness of social, economic, environmental and political considerations. The impact of such technology decisions will be felt for the life of the technology, which could easily exceed 15 - 20 years.

Assessment methods for renewable technologies have been developed over several decades but there is an ongoing need for applying more comprehensive and effective methods. The traditional approaches of applying technical and economical methods are still fundamental to the assessment process, however criteria related to 
environmental, social, and political constraints are gaining in importance due to public sentiment and regulations.

This literature review provides an overview of assessments of renewable energy technologies with respect to five perspectives: social, technological, economical, environmental, and political (STEEP). The focus is on photovoltaic solar energy and related technologies. Keyword searches have been performed in a number of databases containing leading renewable energy-related journals to cover the following themes (also refer to Figure 1):

- Observe gaps in STEEP perspectives and derive STEEP criteria

- Review multi-criteria energy decision modeling approaches

- Review solar and photovoltaic technologies and systems

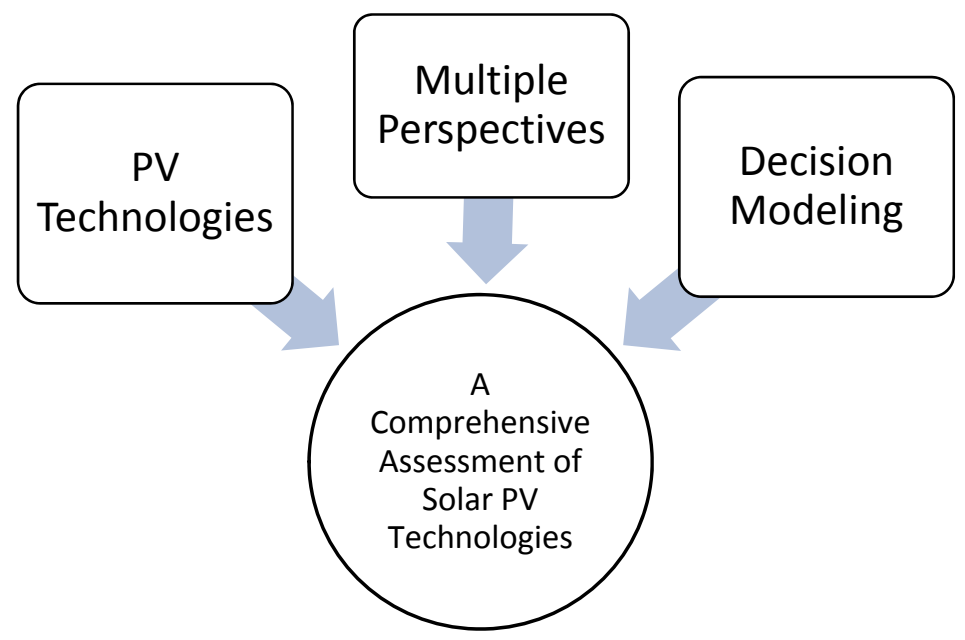

Figure 1: Three Literature Review Themes for Comprehensive PV Technology Assessment 


\subsection{Methodology}

The literature review is designed to study the related body of work to gain knowledge of the current status, trends, gaps, case studies, and approaches in the three areas listed above. It is also meant to be a foundation for future areas of research including the compilation of criteria and factors that make up the STEEP perspectives.

The target domain of this study is renewable energy with a special focus on photovoltaic solar energy. In conducting the study, the publications were organized for analysis using a software tool, Mendeley Desktop. The keywords varied across a broad spectrum but typically included: renewable energy systems, multi-criteria decision making, energy decision modeling, life cycle assessment, and electricity generation. The overall process is summarized in Figure 2 below: 


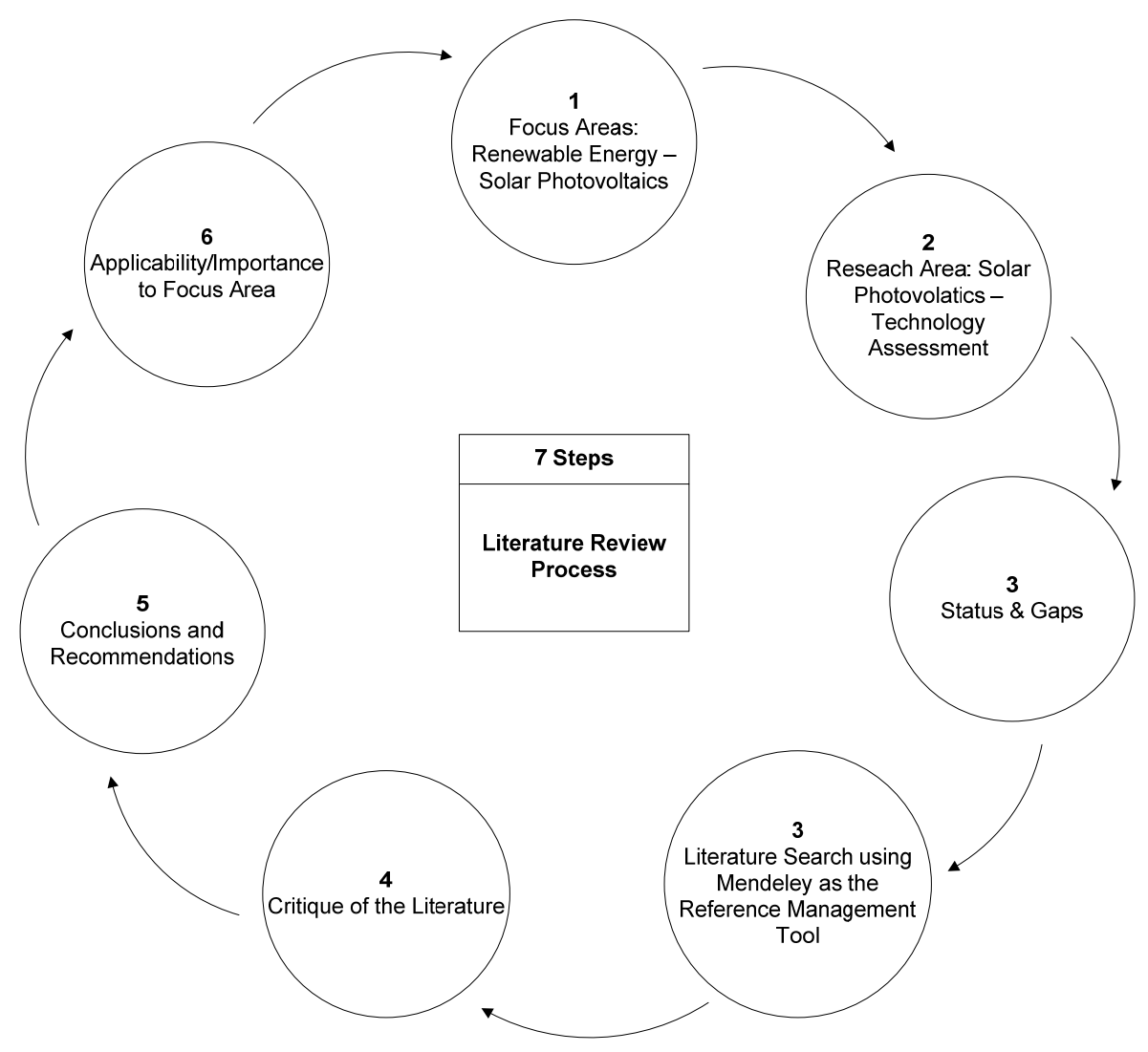

Figure 2: The Literature Review Process

Scanning of the literature resulted in one hundred and seventy-eight papers that were relevant to the research topic. The papers are thematically categorized and partial lists of databases are shown in Table 2. 
Table 1: Number of Papers Reviewed by Theme

\begin{tabular}{|l|c|}
\hline Theme & No. of Papers \\
\hline STEEP criteria & 44 \\
\hline Multi-criteria energy decision modeling & 58 \\
\hline $\begin{array}{l}\text { Photovoltaic solar technologies (including } \\
\text { complementary distribution and storage } \\
\text { systems) }\end{array}$ & 59 \\
\hline $\begin{array}{l}\text { Renewable energy trends and use of multiple } \\
\text { perspectives for technology evaluation }\end{array}$ & 18 \\
\hline \begin{tabular}{l} 
Total \\
\hline
\end{tabular} & 178 \\
\hline
\end{tabular}

Table 2: Sources for Literature Review (Partial Lists)

\section{Databases}

Academic Search Premier

Business Source Premier

Energy Citations Database (DOE Office of Scientific and Tech. Info.)

EconLit

Engineering Village (Compendex)

Information Sciences Institute (ISI)

Web of Science

ISI Current Contents Connect

National Renewable Energy Laboratory (NREL) publications database

World Wide Web (Google)

Sixty-five of these one hundred and seventy-eight papers are cited in this literature review.

\subsection{Solar Photovoltaic Renewable Energy}

Solar PV electricity is an important renewable energy since it has a wide range of enduse applications from utilities to residential rooftops (Figure 3, [17]) and is distributed 
amongst the major countries of the world (Figure 4, [18]). It is expected to provide $11 \%$ of total global electricity generated by 2050 [17].

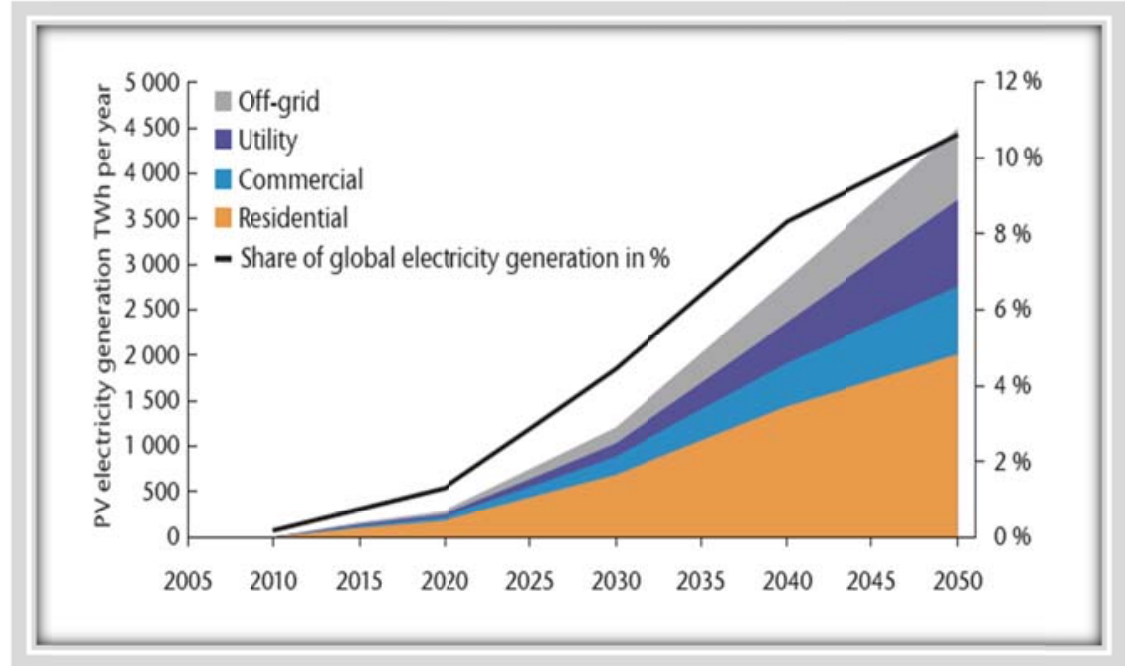

Figure 3: Global Solar PV Electricity Production by End-Use Sector 2010-2050 (2009) [17] 


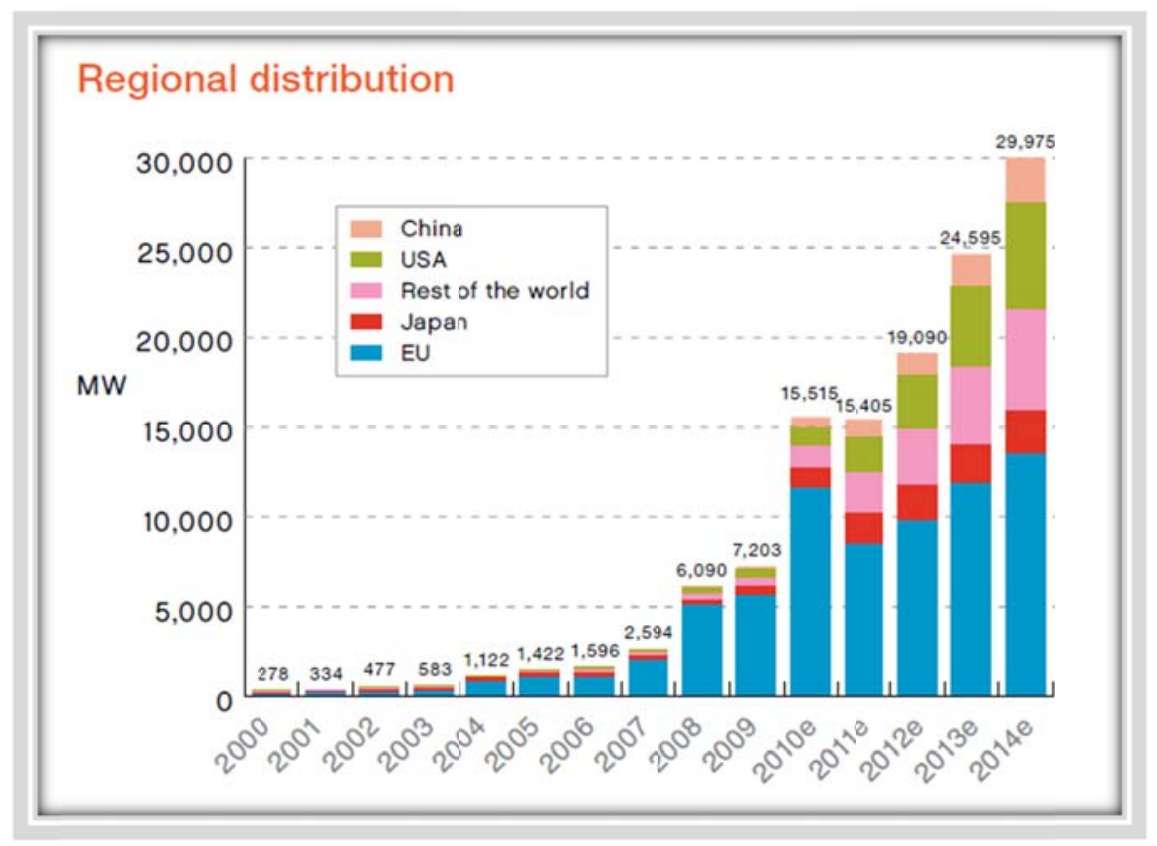

Figure 4: Worldwide Distribution of PV Electricity [18]

[The sharp increase in 2010 is due to pent up demand based on favorable government policies being met by increased capacity of silicon production fulfilling order backlog. The policies had been in place earlier but the market was constrained by shortage of PV silicon supply until 2010.]

Another report by Gigaton Throwdown Initiative indicates that solar PV along with other renewable energy sources will scale up more aggressively than current projections to alleviate CO2 emissions [19]. This report also projects that by 2020 several million new jobs will be created by solar PV alone. It should be noted that this report is an industry publication and the contents reflect the authors' research without going through the refereeing process.

A recent report by the Office of the Vice President of the United States has shown that PV grid parity (which is comparable price of PV to conventional electricity) will be achieved by 2015 - earlier than previously anticipated [20]. Grid parity is an important 
driver for PV adoption since it enables electricity produced by PV to be delivered at current utility or market rates. This is due to the commercial introduction of second generation thin-film solar PV technologies that will compete with first generation silicon-based panels. Hence, homeowners (who pay an average retail cost of about 10 cents/kWh for electricity from the grid) and utility companies (which have average wholesale power costs closer to 5 cents/kWh) will be able to use solar PV power without paying a premium over fossil-based (traditional) electricity. By 2030, the retail and wholesale cost of solar PV will be down to 6 cents/kWh and 5 cents $/ \mathrm{kWh}$ respectively.

\subsection{Solar Photovoltaic Technologies}

There is a proliferation of new PV technologies with varying degrees of performance and claims. New Energy Strategies, a market research firm, has recently published two reports detailing 250+ PV technologies (including variants), production processes, and major R\&D efforts worldwide [8], [10]. These reports cover a range of generations of PV technologies. The common mono/poly crystalline silicon (c-Si)-large glass/thicksilicon panels-deployed worldwide represent the first generation and have been commercially available since the 1960s. NREL (United States National Renewable Energy Laboratory) has maintained, validated, and updated the PV generations chart for over 30 year [21]. The NREL chart clearly shows that significant research in PV has resulted not only in multiple technologies but also in multiple generations of 
technologies (Figure 5). (The latest R\&D is at the $5^{\text {th }}$ generation level.) The trend is towards the use of low-cost and environmentally friendly materials.

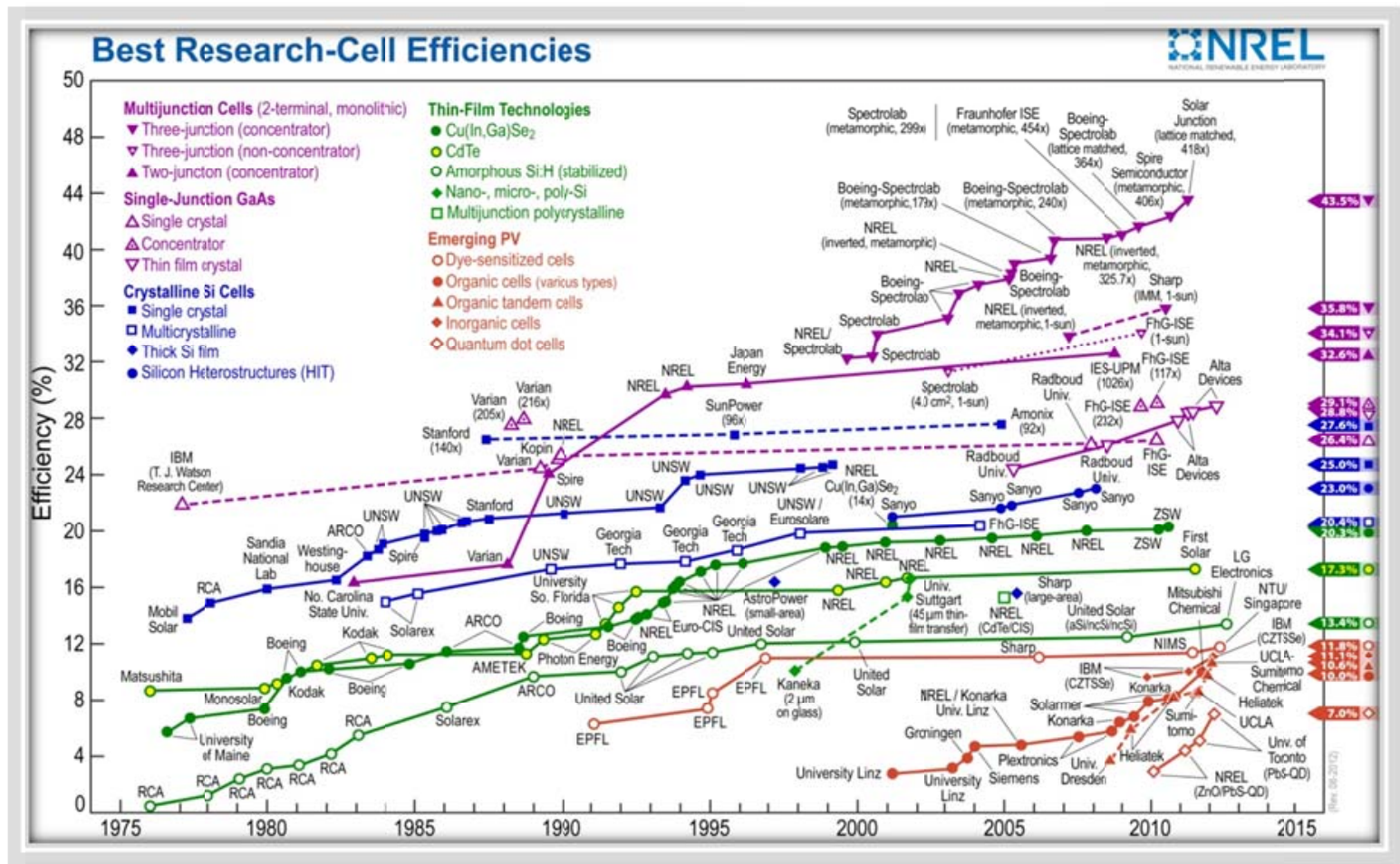

Figure 5: NREL compilation of best research solar cell efficiencies [21]

This crowded playing field with diverse PV technologies contains many that are at or near commercial stages. In order to meet the future energy challenges, it is becoming increasingly important to consider policy making, funding, incentives, and deployment on a vast variety of technology choices [22]. Also, research, development and demonstration (RD\&D) of these new technologies together with market demand at the national and international levels require governments and industry to accelerate energy technology commercialization through a number of parallel and interrelated 
pathways. These pathways include RD\&D, incentives, market mechanisms, regulatory frameworks, information campaigns, and related programs. The policies and programs must be tailored to the specifics of the technology, as well as to the national or regional conditions. The effect of the decisions governments and policy makers make today will be felt for decades.

To address such challenges the application of hierarchical decision models with multiple perspectives and multiple criteria is considered an effective approach.

The following papers represent the role of PV in renewable energy generation and a variety of criteria that are used to characterize, assess, and compare multiple aspects of PV technologies. The papers can be categorized as "technology assessment" and "deployment and market trends".

\subsubsection{Technology Assessment}

There are multiple approaches to technology assessment and multiple types of technologies. Studies cover emerging technologies and mature technologies in solar PV.

Emerging PV technologies are typically evaluated in comparison to commercially available and near-commercial technologies. Azzopardi et al reviewed a variety of 
commercially available photovoltaic (PV) systems are reviewed for life cycle analysis (LCA) and sustainability evaluation [23]. They also compared new hybrid quantum dot (QD)-based solar modules to commercial PV. In 2004, a study was commissioned to review lessons learned from two new thin film PV manufacturing efforts that were eventually abandoned [24]. The purpose was to identify decision and costs to evaluate comparable PV technologies and to gain insights for future developments. A multicriteria method was shown to be a useful tool in assessing the production processes for second generation thin film PV [25]. PV is particularly suited for renewable energy generation due to its simplicity and modularity [26]. In 2008 an expert survey was conducted on 26 commercial and emerging PV technologies [27]. The results indicated the following: average PV price is forecasted to be $\$ 1.20 / \mathrm{Wp}$ (Peak Watts) by 2030 (news from China indicates that the bid price has already dropped to $\$ 0.15 / \mathrm{Wp}$ for massive scale deployments [28]); PV price needs to be at $\$ 0.30 / \mathrm{Wp}$ for it to be considered as a candidate for bulk power; R\&D would increase energy conversion efficiency; deployment incentives will decrease price; governments should continue to invest in PV R\&D to lower cost and reduce uncertainty; governments should be cautious of large deployment subsidies. A study focused on organic photovoltaics (or plastic PV) as a key emergy (available energy to produce a product) technology because of its potential for use of low cost materials and standard production (reel-toreel) processes [29]. 
For commercial PV technologies, the power or electricity grid plays an important role. To gain an overall better understanding of grid-connected PV systems a review of the literature and an analysis was performed with recommendations for inverters and balance-of-system (BOS) [30]. Marion et al of the NREL (National Renewable Energy Laboratory) considered four performance parameters for grid-connected PV systems [31]. These defined the overall system performance with respect to the energy production, solar resource, and overall effect of system losses and included final PV system yield, reference yield, performance ratio, and PVA rating. In a recent analysis it was shown that grid parity (the cost of solar energy to be competitive with conventional electricity) for installed $\mathrm{PV}$ is $\$ 2 / \mathrm{Wp}$. However, $\mathrm{PV}$ may require more than just attaining grid parity for market adoption such as government incentives [32].

Another important aspect is the environmental impact from PV. Tsoutsos et al provide an environmental assessment for deployment of solar systems [33]. PV systems can cover large tracts of landscape and can affect land use, vegetation, microclimate, glare, natural habitat, and natural beauty. This is of concern to local and national governments. A study was performed to understand the effects of PV system installations on the environment with a special focus on the reflected glare from PV panels [34].

New methods are proposed for investing in PV and estimating its value. For example, Shimon Awerbuch argues that for investing in PV, the traditional approach of 
engineering economics does not reflect the true value of PV and better approach is to use the Capital Asset Pricing Model (CAPM) reflecting modern financial theory [35].

\subsubsection{Deployment and Market Trends}

The proliferation of PV deployments has reached epidemic proportions. Despite the decline in European government incentives by 2011 the growth is expected to continue worldwide driven by deployment strategies. One study emphasized the PV production imperative [26]. It stated that PV uses practically unlimited sunshine to produce electricity but currently its contribution is a small fraction of the total electricity supply. To make a significant contribution PV must maintain a growth rate of greater than $40 \%$ with volume productions of 4 orders of magnitude. Using Moore's Law for PV indicates that PV has the potential to achieve the required growth rates similar to those of integrated circuits (ICS) [36]. It was also recommended that standards should be adopted to follow the example of the semiconductor chip industry. Degroat et al presented a systems analysis approach for solar energy adoption. This approach appears to be useful for a variety of decision makers and the public. There are three important aspects of solar deployment acceleration: integration of solar- generated electricity with the electric grid (enabled by a "Smart Grid" infrastructure); continued reduction of manufacturing and deployment costs; and expansion of manufacturing capability [37]. A literature review was also 
performed to identify important past and current market deployment strategies for the broader dissemination of grid-connected PV systems in the built environment [38].

Considering that solar PV viability needs to be part of an effective deployment, a study summarized PV viability and indicated important trends such as significant decrease in costs due to technology improvements and economies of scale in production and increase in use of building integrated PV (BIPV) [39]. Another study analyzed PV systems production for energy requirements and $\mathrm{CO} 2$ emissions. Energy pay-back time (EPBT) was in the range of $2.5-4$ years. $\mathrm{CO} 2$ emissions were calculated to be slightly higher than wind and biomass but still significantly lower than fossil-fuel power plants [40].

Many market surveys and trend analyses have been performed on PV deployments and indicate high growth worldwide. A comprehensive survey report by The International Energy Agency (IEA) details the high growth of grid-connected and offgrid PV power of major countries [41]. In 2008 a study was conducted by Navigant Consulting Inc. $(\mathrm{NCl})$ for the United States Department of Energy (DOE) to model the market adoption of rooftop PV in the U.S from 2007 to 2015. Net metering rules, electric rate tariff levels and structures, availability of financial incentives, system pricing, and carbon legislation were taken into consideration to show the cumulative positive affect these factors on PV adoption [42]. 


\subsubsection{Complementary Technologies: Storage and Distribution}

A brief review of the literature was conducted to determine criteria for complementary storage and distribution technologies that would help to differentiate different photovoltaic solar technologies [43]. It appears that complementary technologies/systems at this point are agnostic to solar energy generation technologies.

In summary, there are many technologies, areas of research, and global market thrusts for PV technologies. However, there appear to be no coherent strategies which can connect policies to market requirements and technology capabilities.

\subsection{Multiple Perspectives, Decision Making, and Technology Assessment}

Harold A. Linstone pioneered the concept of decision making and evaluating technologies using multiple perspectives. He used technical, organizational, and personal (TOP) perspectives and has published extensively on the subject [11], [13], [14], [44]. In strategic management, PEST (Political, Economic, Socio-Cultural, and Technological) analysis is used to assess changes in the business environment [45]. The basic concepts can be expanded and applied to energy technologies, systems, and processes. 
Renewable energy technology development and deployment impact and are impacted by many areas that may complement or contradict one another. It is useful to have a framework that can manage the various aspects or perspectives of these areas to reconcile with the decision making process in the complex real world or public domain. This way it may be possible to answer such questions as: "What perspective is being considered more?", "Who or which group is biased towards that perspective?", "Can the results be explained better knowing the dominant perspective?", and "How can we address the problem if more than one perspective is important?"

Energy sources and technologies are viewed from multiple biases and perspectives depending on the decision maker or stakeholder. Economic feasibility and supply demand relationships that are important from political, social, and economical perspectives. Environmentally conscious societies need to constrain the negative impact of any energy source. Market adoption depends not only on technology excellence but also governmental regulations to accelerate demand. Governments need to consider the security aspect of energy sources if they are not produced locally (such as fossil fuels) and a threat of shortage may occur. Energy generation now needs to be considered holistically to capture the multiple perspectives driving and impacting decisions. As we move into the green or renewable energy era energy analysis or assessment from a STEEP multi-perspective becomes even more important. 
As multiple aspects of the technology are evaluated decisions must be made regarding comparison, selection, and deployment. Multiple decision models and methodologies exist, however before selecting one methodology over another it is better to evaluate these on the basis of appropriateness to renewable energy using multiple perspectives, multiple criteria, and multiple actors/players.

\subsection{Energy Multiple Perspectives: STEEP}

Most studies that engage in energy modeling and evaluation use one or two perspectives [6], [23], [46-55]. Technical perspective is the most common followed by economic. Environmental perspective is in more recent papers. Social and political perspectives are the least considered ones. (Studies which include social and political perspectives are in references [56-59].) Few papers use all the five perspectives but they generally do not go beyond the conceptual level and are not in a state that can be operationalized by practitioners.

Survey of the research on energy multiple perspectives indicates that studies and findings are limited in scope, cover broad criteria (and not specifics related to renewable energy), have limited capability for operationalization, are project or policy oriented, and have almost no reference to specific renewable energy technologies (especially solar PV). 


\subsection{Energy Decision Models}

Energy planning problems are complex with multiple decision makers weighing in with different priorities and objectives which have a basis in multiple criteria ranging from highly quantitative to highly qualitative such as value judgments. Typically, decision makers react subjectively when they receive information about stakeholder preferences-even if the information is structures-thus impacting the reliability, transparency, and defensibility of the decisions. To address these decision making challenges decision making bodies (especially at the policy level) have migrated to a more integrated and comprehensive decision analysis approach such as MCDA [60]. Table 3 summarizes three popular MCDA methods or frameworks.

Table 3: Comparison of Critical Elements of Several Advanced MCDA Methods: MAUT, AHP, and Outranking [60]

\begin{tabular}{|c|c|}
\hline Method & Critical Elements \\
\hline $\begin{array}{l}\text { Analytic Hierarchy Process } \\
\text { (AHP) / Hierarchical } \\
\text { Decision Model (HDM) }\end{array}$ & $\begin{array}{l}\text { - Criteria weights and scores are based on pairwise comparisons of } \\
\text { criteria and alternatives, respectively }\end{array}$ \\
\hline $\begin{array}{l}\text { Multi-Attribute Utility } \\
\text { Theory (MAUT) }\end{array}$ & $\begin{array}{l}\text { - Expression of overall performance of an alternative in a single } \\
\text { nonmonetary number representing the utility of that alternative } \\
\text { - Criteria weights are often obtained by directly surveying } \\
\text { stakeholders }\end{array}$ \\
\hline Outranking & $\begin{array}{l}\text { - One option outranks another if: } \\
\text { 1."it outperforms the other on enough criteria of sufficient } \\
\text { importance (as reflected by the sum of criteria weights)" } \\
\text { and } \\
\text { 2. it "is not outperformed by the other in the sense of recording a } \\
\text { significantly inferior performance on any criterion" } \\
\text { - Allows options to be classified as "incomparable" }\end{array}$ \\
\hline
\end{tabular}


All these methods used a multi-criteria approach for decision analysis to assess and select the most suitable alternative(s). The Analytic Hierarchy Process (AHP) [or Hierarchical Decision Model (HDM)] and Multi-attribute Utility Theory (MAUT) are more complex methods than the third one. The outranking method uses a dominance approach. HDM and MAUT involve scoring the performance of alternatives with respect to criteria and then aggregating onto an overall score. The objective of MAUT is to transform diverse criteria into a common utility or value scale. In MAUT poor scores on criteria can be compensated for by high scores on other criteria and hence MAUT is also referred to a "compensatory" method. Similar to MAUT, HDM aggregates criteria into a single optimized objective function. The goal of HDM is to asses-andselect the alternative that results in the maximum objective function. HDM is also compensatory. HDM uses pairwise comparisons of decision criteria to obtain decision makers' or stakeholders' value judgments. For example, HDM requires the decision maker to answer questions like the following: "To determine the relative importance of the five perspectives with respect to the mission, how would you compare the elements (perspectives: social, technical, economic, environmental, and political) in pairwise comparisons? (Allocate a total of 100 points to reflect how many times a perspective is important in comparison to the other.)" The decision maker uses a numerical scale of 100 to compare the five perspectives, two at a time for a total of 10 times. HDM assumes that we (humans) are more capable of making comparative judgments versus absolute ones. Outranking is quite different than MAUT and HDM. Outranking is based on the principle that one alternative may be more dominant than 
other. However, a single best alternative may not be possible. Outranking compares the performance of two or more alternatives (at a time) with respect to the underlying criterion to determine the preference level of an alternative. Outranking then aggregates this preference information over all relevant criteria and establishes evidence to select a particular alternative.

Several literature reviews on sustainable energy planning conclude that research and publications in the area of energy decision making and planning are gaining in significance with the most popular MCDA method being the hierarchical decision model (HDM) followed by outranking methods PROMETHEE and ELECTRE. The reviews also list related criteria for multiple perspectives [15], [51], [53-55]. (It should be noted that AHP is also the most popular multi-criteria decision making model in management science research and applications [61].)

Literature reviews of energy decision modeling indicate that although the most popular model used is a hierarchical decision model, the use of all STEEP perspectives is not common. The criteria tend to be broad and difficult to operationalize for practitioners, and that there is no published research on criteria specific to solar PV. The HDM lends itself easily to a layered approach of ranking and prioritizing perspectives and their associated criteria and factors. An HDM developed by Dundar Kocaoglu (also referred to as the "MOGSA"-Mission, Objectives, Goals, Strategies, Actions-model) is utilized by the author for this research [62]. 
Selected journal papers representing a variety of decision making aids and methods used in the energy sector for planning, project selection, environmental, and social impact are highlighted below.

About half of the papers are literature reviews of multi-criteria decision analysis which include reference to energy and sustainability. One review covered an established multi-criteria decision analysis (MCDA) approach, the PROMETHEE (Preference Ranking Organization Method for Enrichment Evaluations) family of outranking methods, which has been used for decision making in multiple applications since 1982 [50]. A key application is "energy management" which includes energy planning, renewable energy scenarios, new energy system development, etc. This is a comprehensive review of methodologies and applications including multiple perspectives for energy but there is no reference to a solar or PV case study. Another review is on MCDA and energy-oriented decision making for energy and electricity planners to typically address emerging problems such as the conflict between economic and environmental objectives [51]. This review includes comparative evaluation of power technologies but indicates that it is difficult to operationalize the findings, stating, "The aim is to prioritize the available technological options, while the-often not explicitly stated-intention is to establish development plans and accordingly direct policy instruments. However, it is hardly visible how the obtained rankings will be translated into operational action plans or policy priorities." Energy 
planning decisions require addressing complex problems that are based on multiple criteria-many time conflicting criteria and objectives-and involve many decision makers and stakeholders. Two reviews performed a comprehensive analysis of the literature for multiple criteria decision analysis with respect to energy (including renewable) planning to conclude that most of the decision analyses are comparable and no one model stands out [52], [63]. A good alternative might be combining two or more methods to leverage the strengths of each method.

Some papers have developed novel methods such as a multi-criteria decision making approach using linguistic variables in fuzzy logic to assist policy makers in defining sustainable technological energy priorities [64], scenario analysis with participatory decision analysis with a focus on the challenges in the methodology [65], and applying game theory to energy policy [66]. The hierarchical decision model AHP has been extended to ANP (Analytic Network Process-a variant of AHP which allows for relationships between criteria) and FAHP (fuzzy analytic hierarchy process). ANP is used to model economical, social, and political perspectives on energy [67] and to select R\&D projects [68]. FAHP is applied to renewable energy research and policy making [69] .

Another set of papers develop the framework for decision analysis which can be applied to renewable energy planning [53], [70], [71]. 


\subsection{Gaps in the Literature}

The gaps in STEEP assessment for each of the literature review papers are summarized in Table 4. As a consequence of this literature review it was possible to compile a large number of criteria and factors for each perspective which together with value/desirability functions may enable decision makers to select best suited technologies for prescribed objectives. 
Table 4: STEEP Gap Table

\begin{tabular}{|c|c|c|c|c|}
\hline Title & Highlight & Authors & Year & Gap/Limitation \\
\hline \multicolumn{5}{|c|}{ Energy Multiple Perspectives (STEEP): Review and Criteria } \\
\hline $\begin{array}{l}\text { Learning from the social construction of } \\
\text { environmental indicators : From the } \\
\text { retrospective to the pro-active use of } \\
\text { SCOT in technology development }\end{array}$ & $\begin{array}{l}\text { Developing of a set of environmental indicators } \\
\text { for buildings (EIFOBs) that could facilitate the } \\
\text { consideration of environmental aspects in various } \\
\text { decision-making situations and across various } \\
\text { groups of actors. Four perspectives (Frames) are } \\
\text { considered: Public- Relations, Scientific, } \\
\text { Aesthetic-Holistic, Lay-person Sensualistic. }\end{array}$ & Elle et al & 2009 & $\begin{array}{l}\text { Social, Technical, } \\
\text { Economic, } \\
\text { Environmental, and } \\
\text { Political (STEEP) } \\
\text { perspectives covered at } \\
\text { conceptual or framework } \\
\text { level }\end{array}$ \\
\hline $\begin{array}{l}\text { Decomposition Analysis and Design of } \\
\text { Sustainable Renewable Energy Systems: } \\
\text { A New Approach }\end{array}$ & $\begin{array}{l}\text { Framework for sustainable renewable energy } \\
\text { systems presented including sustainable } \\
\text { renewable energy technologies (RETs) and socio- } \\
\text { economic perspective based decision making. }\end{array}$ & Polatidis et al & 2007 & $\downarrow$ \\
\hline A review of energy models & $\begin{array}{l}\text { Review of renewable energy planning/forecasting } \\
\text { models including: energy supply-demand models, } \\
\text { forecasting models, renewable energy models, } \\
\text { emission reduction models, and optimization } \\
\text { models }\end{array}$ & Jebaraj et al & 2004 & \\
\hline $\begin{array}{l}\text { Multi-criteria decision analysis as an aid } \\
\text { to the strategic planning of energy } R \& D\end{array}$ & $\begin{array}{l}\text { Multiperspective decision analysis to assist } \\
\text { government advisory councils (for Netherlands) }\end{array}$ & Lootsma et al & 1986 & \\
\hline $\begin{array}{l}\text { Distributed Generation: Toward a New } \\
\text { Energy Paradigm }\end{array}$ & $\begin{array}{l}\text { Review of requirements and R\&D direction } \\
\text { needed for distributed power generation } \\
\text { including transmission and control of power } \\
\text { electronics. }\end{array}$ & Guerrero et al & 2010 & $\begin{array}{l}\text { Partial STEEP } \\
\text { perspectives covered. }\end{array}$ \\
\hline $\begin{array}{l}\text { Renewable Energy - How Much of an } \\
\text { Option Is It? }\end{array}$ & $\begin{array}{l}\text { Reviews renewable energy sources (for US) and } \\
\text { their shortcomings. Proposes benefits of nuclear. }\end{array}$ & Jakuba, S. & 2009 & 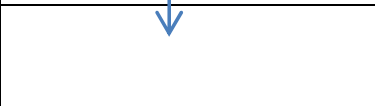 \\
\hline
\end{tabular}




\begin{tabular}{|l|l|l|l|l|}
\hline $\begin{array}{l}\text { Valuation for renewable energy: A } \\
\text { comparative review }\end{array}$ & $\begin{array}{l}\text { Literature review of environmental cost-benefit } \\
\text { analysis applied to evaluation of renewable } \\
\text { energy projects. [Methods are: stated preference } \\
\text { techniques, revealed preference techniques, } \\
\text { portfolio analysis, emergy analysis, and various } \\
\text { other economic but not welfare-based oriented } \\
\text { methods.] }\end{array}$ & Menegaki, A. & 2008 & \\
\hline $\begin{array}{l}\text { Renewable energy systems: A societal } \\
\text { and technological platform }\end{array}$ & $\begin{array}{l}\text { Planning platform developed to include socio- } \\
\text { economic aspects of renewable energy and to } \\
\text { provide operational analytical decomposition. } \\
\text { Wind Energy case study reviewed. }\end{array}$ & Polatidis et al & 2007 & \\
\hline $\begin{array}{l}\text { Nontechnical Barriers to Solar Energy } \\
\text { Use: Review of Recent Literature }\end{array}$ & $\begin{array}{l}\text { Literature review of barriers to PV (and } \\
\text { renewable energy) diffusion. }\end{array}$ & Margolis et al & 2006 & \\
\hline $\begin{array}{l}\text { Solar energy's economic and social } \\
\text { benefits }\end{array}$ & $\begin{array}{l}\text { Comparison of social costs and benefits and } \\
\text { elements of cost in energy chain for solar energy }\end{array}$ & Scheer, H. & 1995 & \\
\hline $\begin{array}{l}\text { Soft-systems model of energy } \\
\text { management and checklists for energy } \\
\text { managers }\end{array}$ & $\begin{array}{l}\text { Power plant energy management process } \\
\text { described using "soft-systems" approach for 4 } \\
\text { levels: good housekeeping, retro-fit, new } \\
\text { equipment purchase, and new process } \\
\text { development. Also includes a checklist for new } \\
\text { systems. }\end{array}$ & Fawkes, S. & 1987 & \\
\hline
\end{tabular}




\begin{tabular}{|c|c|c|c|c|}
\hline Title & Highlight & Authors & Year & Gap/Limitation \\
\hline \multicolumn{5}{|l|}{ Energy Decision Models } \\
\hline $\begin{array}{l}\text { PROMETHEE: A comprehensive literature } \\
\text { review on methodologies and } \\
\text { applications }\end{array}$ & $\begin{array}{l}\text { Literature review of PROMETHEE for MCDA } \\
\text { (multi-criteria decision aid) cases. Includes } \\
\text { sections on Energy and Environment } \\
\text { Management and comparison with AHP. }\end{array}$ & Behzadian et al & 2010 & $\begin{array}{l}\text { Literature reviews of } \\
\text { energy decision model } \\
\text { studies with partial or } \\
\text { conceptual-level STEEP } \\
\text { perspectives covered, very } \\
\text { few PV studies }\end{array}$ \\
\hline $\begin{array}{l}\text { Multi-criteria decision-making selection } \\
\text { model with application to chemical } \\
\text { engineering management decisions }\end{array}$ & $\begin{array}{l}\text { Literature review of multicriteria decision making } \\
\text { (MCDM) approaches for } R \& D \text { projects. }\end{array}$ & Pirdashti et al & 2009 & \multirow[t]{2}{*}{$\downarrow$} \\
\hline $\begin{array}{l}\text { Review on multi-criteria decision analysis } \\
\text { aid in sustainable energy decision- } \\
\text { making }\end{array}$ & $\begin{array}{l}\text { Literature review of multi-criteria decision- } \\
\text { making for sustainable energy including criteria } \\
\text { selection, criteria weighting, evaluation, and final } \\
\text { aggregation. }\end{array}$ & Wang et al & 2009 & \\
\hline $\begin{array}{l}\text { Use of multicriteria decision analysis } \\
\text { methods for energy planning problems }\end{array}$ & $\begin{array}{l}\text { Literature review of MCDA for energy planning } \\
\text { including multiple providers. }\end{array}$ & Loken, E & 2007 & \\
\hline $\begin{array}{l}\text { Decision analysis in energy and } \\
\text { environmental modeling: An update }\end{array}$ & $\begin{array}{l}\text { Literature review of multi-criteria decision models } \\
\text { for energy. }\end{array}$ & Zhou et al & 2006 & \\
\hline MCDA and Energy Planning & $\begin{array}{l}\text { Literature review of multi-criteria decision- } \\
\text { making for energy planning. }\end{array}$ & Diakoulaki et al & 2005 & \\
\hline $\begin{array}{l}\text { Application of multi-criteria decision } \\
\text { making to sustainable energy planning-A } \\
\text { review }\end{array}$ & $\begin{array}{l}\text { Literature review and usage of decision models } \\
\text { for renewables }\end{array}$ & Pohekar et al & 2004 & \\
\hline
\end{tabular}




\begin{tabular}{|c|c|c|c|c|}
\hline $\begin{array}{l}\text { An assessment of exploiting renewable } \\
\text { energy sources with concerns of policy } \\
\text { and technology }\end{array}$ & $\begin{array}{l}\text { Fuzzy analytic hierarchy process (FAHP) is used to } \\
\text { resolve multi-goal problem for achieving } \\
\text { renewable energy research and policy making. }\end{array}$ & Shen et al & 2010 & $\begin{array}{l}\text { Energy decision model } \\
\text { studies with partial STEEP } \\
\text { perspectives covered with } \\
\text { selection among } \\
\text { renewable energy types } \\
\text { (not specific to PV } \\
\text { technology selection) }\end{array}$ \\
\hline $\begin{array}{l}\text { A comparative analysis for multiattribute } \\
\text { selection among renewable energy } \\
\text { alternatives using fuzzy axiomatic design } \\
\text { and fuzzy analytic hierarchy process }\end{array}$ & $\begin{array}{l}\text { Fuzzy analytic hierarchy process (FAHP) and fuzzy } \\
\text { axiomatic design (FAD) are used to determine the } \\
\text { best renewable energy alternative. }\end{array}$ & Kahraman et al & 2009 & \multirow[t]{2}{*}{$\downarrow$} \\
\hline $\begin{array}{l}\text { Sustainable energy future: } \\
\text { Methodological challenges in combining } \\
\text { scenarios and participatory multi-criteria } \\
\text { analysis }\end{array}$ & $\begin{array}{l}\text { Use of scenario analysis and PMCA for renewable } \\
\text { energy decision modeling }\end{array}$ & Kowalski et al & 2009 & \\
\hline $\begin{array}{l}\text { An Analytic Network Process approach to } \\
\text { the planning and managing of the energy } \\
\text { politics }\end{array}$ & $\begin{array}{l}\text { AHP modeling for } 3 \text { scenarios: minimum } \\
\text { environmental effect, high economic and social } \\
\text { benefit, save energy and increase global energy } \\
\text { system efficiency }\end{array}$ & Gurbuz et al & 2009 & \\
\hline $\begin{array}{l}\text { Multi-criteria decision aid for the } \\
\text { formulation of sustainable technological } \\
\text { energy priorities using linguistic variables }\end{array}$ & $\begin{array}{l}\text { Selection of renewable energy for policy decisions } \\
\text { (in Greece); } 10 \text { candidates evaluated. }\end{array}$ & Doukas et al & 2007 & \\
\hline $\begin{array}{l}\text { Selecting an Appropriate Multi-Criteria } \\
\text { Decision Analysis Technique for } \\
\text { Renewable Energy Planning }\end{array}$ & $\begin{array}{l}\text { Methodological framework provides multi-criteria } \\
\text { decision making techniques for renewable energy } \\
\text { planning. }\end{array}$ & Polatidis et al & 2006 & \\
\hline $\begin{array}{l}\text { R\&D project selection using the analytic } \\
\text { network process }\end{array}$ & $\begin{array}{l}\text { Multiperspective decision making process for } \\
\text { project selection }\end{array}$ & Meade et al & 2002 & \\
\hline
\end{tabular}




\begin{tabular}{|c|c|c|c|}
\hline $\begin{array}{l}\text { Sustainable decision making: the role of } \\
\text { decision support systems }\end{array}$ & $\begin{array}{l}\text { Highlights differences in decision modeling for } \\
\text { sustainability }\end{array}$ & Hersh, M. & 1997 \\
\hline $\begin{array}{l}\text { A Quantitative Model for the Evaluation } \\
\text { of Technological Alternatives }\end{array}$ & $\begin{array}{l}\text { Quantitative model for choosing the appropriate } \\
\text { technology among available alternatives. A case } \\
\text { study on transportation systems is presented. }\end{array}$ & Sharif et al & 1983 \\
\hline $\begin{array}{l}\text { Operational gaming for energy policy } \\
\text { analysis }\end{array}$ & $\begin{array}{l}\text { Applying game theory to energy policy and } \\
\text { multiple decision makers (interaction) }\end{array}$ & Saaty et al & 1977 \\
\hline
\end{tabular}




\begin{tabular}{|c|c|c|c|c|}
\hline Title & Highlight & Authors & Year & Gap/Limitation \\
\hline \multicolumn{5}{|l|}{ Solar/PV Technologies and Systems } \\
\hline The viability of solar photovoltaics & $\begin{array}{l}\text { Summarizes special issue of Energy Policy (2000) } \\
\text { and potential of PV via BIPV driven by policy. }\end{array}$ & Jackson et al & 2000 & $\begin{array}{l}\text { Social, Technical, } \\
\text { Economic, Environmental, } \\
\text { and Political (STEEP) } \\
\text { perspectives covered at } \\
\text { conceptual-level }\end{array}$ \\
\hline Moore's Law of Photovoltaics & $\begin{array}{l}\text { Roadmap of PV technologies and power } \\
\text { production to 2030. Also shows power densities } \\
\text { for energies. }\end{array}$ & Bowden et al & 2010 & $\begin{array}{l}\text { Technical and Economic } \\
\text { perspectives covered. }\end{array}$ \\
\hline $\begin{array}{l}\text { A comparative assessment of thin-film } \\
\text { photovoltaic production processes using } \\
\text { the ELECTRE III method }\end{array}$ & $\begin{array}{l}\text { Multicriteria decision analysis for selection of } \\
\text { thin-film PV production. }\end{array}$ & Cavallaro, $\mathrm{F}$. & 2010 & $\downarrow$ \\
\hline $\begin{array}{l}\text { Systems Analysis and Recommendations } \\
\text { for R\&D and Accelerated Deployment of } \\
\text { Solar Energy }\end{array}$ & $\begin{array}{l}\text { Key solar adoption accelerators indentified for } \\
\text { solar value creation. }\end{array}$ & Degroat et al & 2009 & \\
\hline $\begin{array}{l}\text { Solar Cells And Modules - Global Market } \\
\text { Trends }\end{array}$ & Market research report (outline) & BizAcumen, Inc & 2009 & \\
\hline $\begin{array}{l}\text { Expert Assessments of Future } \\
\text { Photovoltaic Technologies }\end{array}$ & $\begin{array}{l}\text { Economic and technical evaluation of } 26 \text { solar } \\
\text { technologies }\end{array}$ & Curtright et al & 2008 & \\
\hline $\begin{array}{l}\text { Trends in Photovoltaic Applications- } \\
\text { Survey report of selected IEA countries } \\
\text { between } 1992 \text { and } 2007\end{array}$ & Review of global production of PV solar energy & $\begin{array}{l}\text { International } \\
\text { Energy Agency }\end{array}$ & 2008 & \\
\hline $\begin{array}{l}\text { Rooftop Photovoltaics Market } \\
\text { Penetration Scenarios Rooftop } \\
\text { Photovoltaics Market Penetration } \\
\text { Scenarios }\end{array}$ & $\begin{array}{l}\text { Modeling of market penetration of rooftop } \\
\text { photovoltaics in US under a variety of scenarios, } \\
\text { on a state-by-state basis, from } 2007 \text { to } 2015\end{array}$ & Paidipati et al & 2008 & \\
\hline
\end{tabular}




\begin{tabular}{|c|c|c|c|c|}
\hline $\begin{array}{l}\text { Experience Scaling-Up Manufacturing of } \\
\text { Emerging Photovoltaic Technologies }\end{array}$ & $\begin{array}{l}\text { Case study of BP solar and its abandonment of } 2 \\
\text { thin-film PV commercialization efforts. }\end{array}$ & Braun et al & 2007 & \\
\hline $\begin{array}{l}\text { Organic photovoltaics: technology and } \\
\text { market }\end{array}$ & $\begin{array}{l}\text { Organic photovoltaics are attractive because of } \\
\text { potential of reel to reel processing on low cost } \\
\text { substrates with standard coating and printing } \\
\text { processes. }\end{array}$ & Brabec, C. & 2004 & \\
\hline $\begin{array}{l}\text { Standards Can Take PV to Its Gold Medal } \\
\text { Game }\end{array}$ & $\begin{array}{l}\text { How standards can improve the penetration of } \\
\text { PV. Analogy with semiconductor industry is given. }\end{array}$ & Nelson, B. & 2010 & $\begin{array}{l}\text { Economic and } \\
\text { Environmental } \\
\text { perspectives covered. }\end{array}$ \\
\hline $\begin{array}{l}\text { Grid-connected photovoltaic power } \\
\text { systems: Technical and potential } \\
\text { problems-A review }\end{array}$ & Focus on grid-connected PV. & Eltawil et al & 2009 & $\downarrow$ \\
\hline $\begin{array}{l}\text { Performance parameters for grid- } \\
\text { connected PV systems }\end{array}$ & $\begin{array}{l}\text { Four performance parameters are considered. } \\
\text { These define the overall system performance } \\
\text { with respect to the energy production, solar } \\
\text { resource, and overall effect of system losses. } \\
\text { They are: final PV system yield, reference yield, } \\
\text { performance ratio, and PVUSA rating. }\end{array}$ & Marion et al & 2005 & \\
\hline Energy viability of photovoltaic systems & $\begin{array}{l}\text { Energy requirements and } \mathrm{CO} 2 \text { emissions for PV } \\
\text { cell production presented with respect to fossil- } \\
\text { fuel power plants and other forms of renewable } \\
\text { energy. }\end{array}$ & Alsema et al & 2000 & \\
\hline Annual Energy Review: 2008 (US) & $\begin{array}{l}\text { Included are statistics on total energy production, } \\
\text { consumption, trade, and energy prices; overviews } \\
\text { of petroleum, natural gas, coal, electricity, } \\
\text { nuclear energy, renewable energy, and } \\
\text { international petroleum; carbon dioxide } \\
\text { emissions; and data unit conversions. }\end{array}$ & US EIA & 2009 & $\begin{array}{l}\text { Economic perspective } \\
\text { covered. }\end{array}$ \\
\hline
\end{tabular}




\begin{tabular}{|l|l|l|l|l|}
\hline $\begin{array}{l}\text { Investing in photovoltaics: risk, } \\
\text { accounting and the value of new } \\
\text { technology }\end{array}$ & $\begin{array}{l}\text { Financial analysis of PV should be based on } \\
\text { Capital Asset Pricing Model (CAPM) and not on } \\
\text { outmoded engineering economics to reflect the } \\
\text { true value of PV. }\end{array}$ & Awerbuch, S. & 2000 & \\
\hline Reconsidering Grid Parity & $\begin{array}{l}\text { Grid Parity for installed PV is calculated (and is } \\
\text { different than the PV cell-based). Also other } \\
\text { drivers such as government incentives are } \\
\text { important for market adoption. }\end{array}$ & Yang, C. & 2010 & \\
\hline $\begin{array}{l}\text { Life cycle analysis for future photovoltaic } \\
\text { systems using hybrid solar cells }\end{array}$ & $\begin{array}{l}\text { Focus on environmental aspect of future PV } \\
\text { systems life cycle analysis (LCA). }\end{array}$ & Azzopardi et al & 2010 & $\begin{array}{l}\text { Environmental perspective } \\
\text { covered. }\end{array}$ \\
\hline $\begin{array}{l}\text { The territorial and landscape impacts of } \\
\text { photovoltaic systems: Definition of } \\
\text { impacts and assessment of the glare risk }\end{array}$ & $\begin{array}{l}\text { Defines land impact types due to PV and provides } \\
\text { case study of one type (Glare in Italy) }\end{array}$ & $\begin{array}{l}\text { Chiabrando et } \\
\text { al }\end{array}$ & 2009 & Tsoutsos et al \\
\hline $\begin{array}{l}\text { Environmental impacts from the solar } \\
\text { energy technologies }\end{array}$ & $\begin{array}{l}\text { Paper presents an Environmental Impact } \\
\text { Assessment for solar technologies }\end{array}$ & 2005 & 2003 \\
\hline $\begin{array}{l}\text { Market deployment strategies for } \\
\text { photovoltaics: an international review }\end{array}$ & Global overview of PV deployments and policies & Haas, R. & $\begin{array}{l}\text { Political perspective } \\
\text { covered. }\end{array}$ \\
\hline
\end{tabular}




\subsection{Conclusion}

\subsubsection{Literature Review: Addressing the Main Objective}

The main objective of the literature review was to understand the state-of-the art and to identify gaps that would, if resolved, make a material contribution to research in the comprehensive assessment of solar photovoltaic technologies.

A multi-faceted literature review was performed in order to analyze and summarize the body of scholarly work in the area of renewable technologies assessments with respect to the five social, technological, economical, environmental, and political perspectives and multi-criteria decision modeling and methodologies.

\subsubsection{Building Criteria Sets By Perspective}

A secondary objective of this literature review was to first build sets of criteria for each perspective based on the existing body of knowledge and then add to these sets through newly identified criteria based on developing experiential knowledge and expert surveys. This, in fact, is an ongoing process due to the changing landscape of renewable energy. Policy makers - at international, national, regional, and local levels, utilities, and manufacturers will constantly need to assess and compare technology and energy options. Hence, there is value in building and updating extensive sets of criteria to be considered for technology assessments. This is especially true for social, environmental, and political perspectives. As a consequence of this literature review it 
was possible to compile a large number of criteria and factors for each perspective which together with desirability/value functions may enable decision makers to select best suited technologies for prescribed objectives.

\subsubsection{Decision Modeling}

It is important to survey the decision models that have been used in energy planning and assessment to gain insights into approaches and gaps in the literature and previous research. Any candidate model should have the capability to be flexible and scalable with respect to multiple perspectives, multiple actors (decision makers, stakeholders, practitioners, end users, etc.), multiple criteria, and ability to provide guidance to practitioners and operational management. Thus such models can provide both assessment and direction. For example, criteria desirability (or utility) functions can provide guidance to R\&D (or policy makers) to focus on a criterion which has a high gap with respect to optimal desirability even though the overall ranking for the technology with respect to the five STEEP perspectives was measured as high.

\subsubsection{Research Gaps}

The literature review revealed the following gaps in technology assessment:

The narrative on STEEP perspectives assessment is generally at a conceptual level without specific details of criteria or metrics to enable research, development engineering, operations, and production to make the findings actionable. When 
specific criteria are detailed then it is around energy planning and not technology assessment.

Typically all five STEEP perspectives are not considered in one evaluation. Journal papers tend to be focused around 3 clusters of perspectives: (1) Technical and Economical (TE), (2) Social and Political (SP), and (3) Social, Environmental, and Political (SEP)

A wide variety of multi-criteria decision making methods are used in energy planning and renewable energy comparisons. There is no one method which is the best, however hierarchical decision making (such as AHP) appears to be popular. The decision making tends to be a ranking or comparative assessment of different types of renewable energy sources (wind, PV, biomass, nuclear, wave, etc.) and not a comparison of technology/system options within the same renewable energy area. For example, comparison of competing PV technologies such as: c-Si (mono/poly crystalline silicon), a-Si (amorphous silicon), CdTe (cadmium telluride thin film), CIGS (copper indium gallium (di)selenide), OPV (organic/plastic PV), and QD (quantum dot) has not been attempted. 


\subsubsection{Proposed Research}

A potential methodology to alleviate the gaps in existing technology assessments for renewable energy (and specifically photovoltaics) is to develop a hierarchical decision model (HDM) with the five STEEP perspectives forming the top level of the hierarchy.

Such a framework for PV technology assessment is sketched in Figure 6 where the alternatives to be assessed may include competing PV technologies such as: c-Si, a-Si, CdTe, CIGS, OPV, and QD.

Hence a comprehensive PV technology assessment methodology consists of the following steps:

1. Build and validate Hierarchical Decision Model (HDM) for STEEP perspectives, criteria, and factors.

2. Obtain relative importance of each perspective, criterion, and sub-criterion (factor) by quantifying expert judgments.

3. Develop desirability functions for various levels of performance metrics corresponding to each sub-criterion (factor).

4. Select PV technologies for assessment.

5. Obtain the performance metrics of the selected PV technologies for subcriterion (factor).

6. Map the performance metrics to the desirability functions. 
7. Make recommendations to decision makers based on the contribution of the relative values of the factors and criteria and desirability values of the performance metrics.

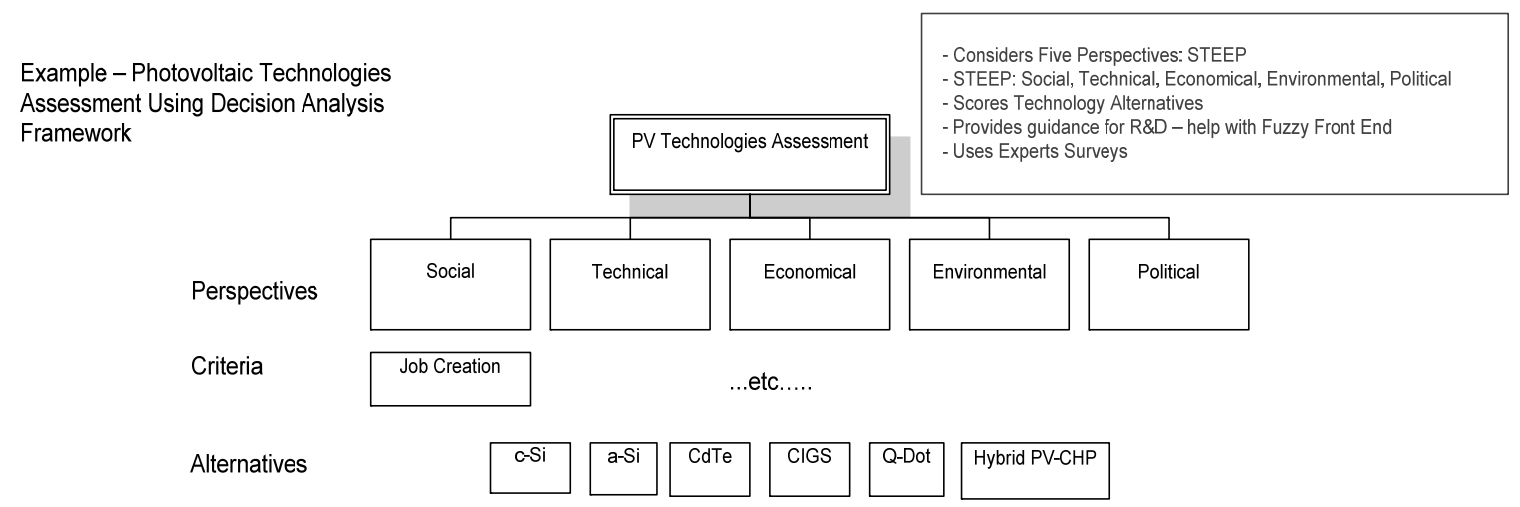

Figure 6: Example - Photovoltaic Technologies Assessment Using Decision Analysis Framework 


\section{VALUE OF MULTIPLE PERSPECTIVES: ILLUSTRATIONS}

The following observations illustrate the value of hierarchical decision modeling:

- Five thick and thin-film PV technologies will be assessed with the STEEP perspectives. One technology will score the highest. This "winning technology" may still have "low value or high gap" in certain important criteria related to environmental and political perspectives. Recommendations are then made on ways and means to improve those criteria. At the same time "high value or low gap" criteria will be systematically identified for promotional or roadmap functions. For example, the winning PV technology could be copper indium gallium (di)selenide) (“CIGS") but big criteria gaps for improvement could be "production" and "decommissioning and indium disposal".

- Gaps and areas of improvement will also be identified for the "non-winning PV technologies". This information would be useful for the manufacturers so they can direct their research and development funding appropriately.

- A case study also illustrates the potential value of HDM for planning. Solyndra was a California-based manufacturer that produced cylindrical CIGS thin-film solar cells-a highly publicized new technology. The company claimed that their configurations produced more electricity per rooftop than a conventional solar panel installation. However, the company could not compete against the traditional silicon solar cells due to plummeting prices and was forced into bankruptcy. The Solyndra debacle became a major embarrassment to the 
Obama administration [72]. Solyndra's novel technology was only a differentiation when materials costs were high. However, these costs plummeted when the Chinese banks issued multibillion dollar loans to national solar companies such as Suntech and Trina Solar [73] . A broader upfront evaluation of the Solyndra technology in comparison with the dominant crystalline Silicon (c-Si) or thick-film PV technology and considering multiple perspectives and criteria could have averted the funding of a company that would not be able to maintain its price advantage. For example, forward pricing trends as part of the financial analysis (to mention one criterion) had not been considered in the assessment of the Solyndra technology. By using HDM and developing "what-if" scenarios through sensitivity analysis would enable decision makers to observe the effect of changing the relative values of perspectives or key criteria on the ranking of their technology versus c-Si, a-Si, or CdTe. This would provide better decision making insight than considering a static commercial environment and a focus on only the technical and economic perspectives.

Such analysis is also important for policy makers that need to understand the overall STEEP impact on the evaluated PV technologies. 


\section{RESEARCH APPROACH}

\subsection{Research Objective}

The objective of this research is to develop a comprehensive method to evaluate solar PV technologies under the STEEP perspectives.

This research will enable decision makers to make decisions in a complex environment with many competing criteria and perspectives. The need for PV technology assessment may arise from different considerations such as national policy, deployment, development, and research.

\subsection{Research Questions}

The research questions address the three gaps (found in the literature) stated above. These can be stated as:

- How can a technology assessment model be built, including the five perspectives together with the robust set of criteria and factors that will enable the model to be operationalized?

- Can this model be standardized as a decision model that will enable researchers and practitioners to enable a broad variety of renewable and/or solar technologies to be evaluated?

- How can the following stakeholders be assisted to make better decisions on technology evaluation and commercialization: 

a. Policy makers
b. Technology suppliers
c. Energy utilities
d. Universities, research institutes, and national laboratories

\subsection{Research Process and Methodology}

The objective of this research is to develop a systematic decision making model for the comprehensive evaluation of solar PV technologies. The model will enable decision makers in government, research, and industry to make better decisions by considering a holistic approach of the five STEEP perspectives.

The research process consists of five major stages:

- Stage 1: Building of the Hierarchical Decision Model

- Stage 2: Expert Panel Selection

- Stage 3: Data Acquisition and Validation

- Stage 4: Analysis of the Results

- Stage 5: Sensitivity Analysis

These stages are summarized in the following sections. 


\subsubsection{Stage 1: Building of the Hierarchical Decision Model}

The decision model is developed by first setting the mission and perspectives for the model and the criteria that would be used to select the most desired target market.

This is depicted in Figure 7.
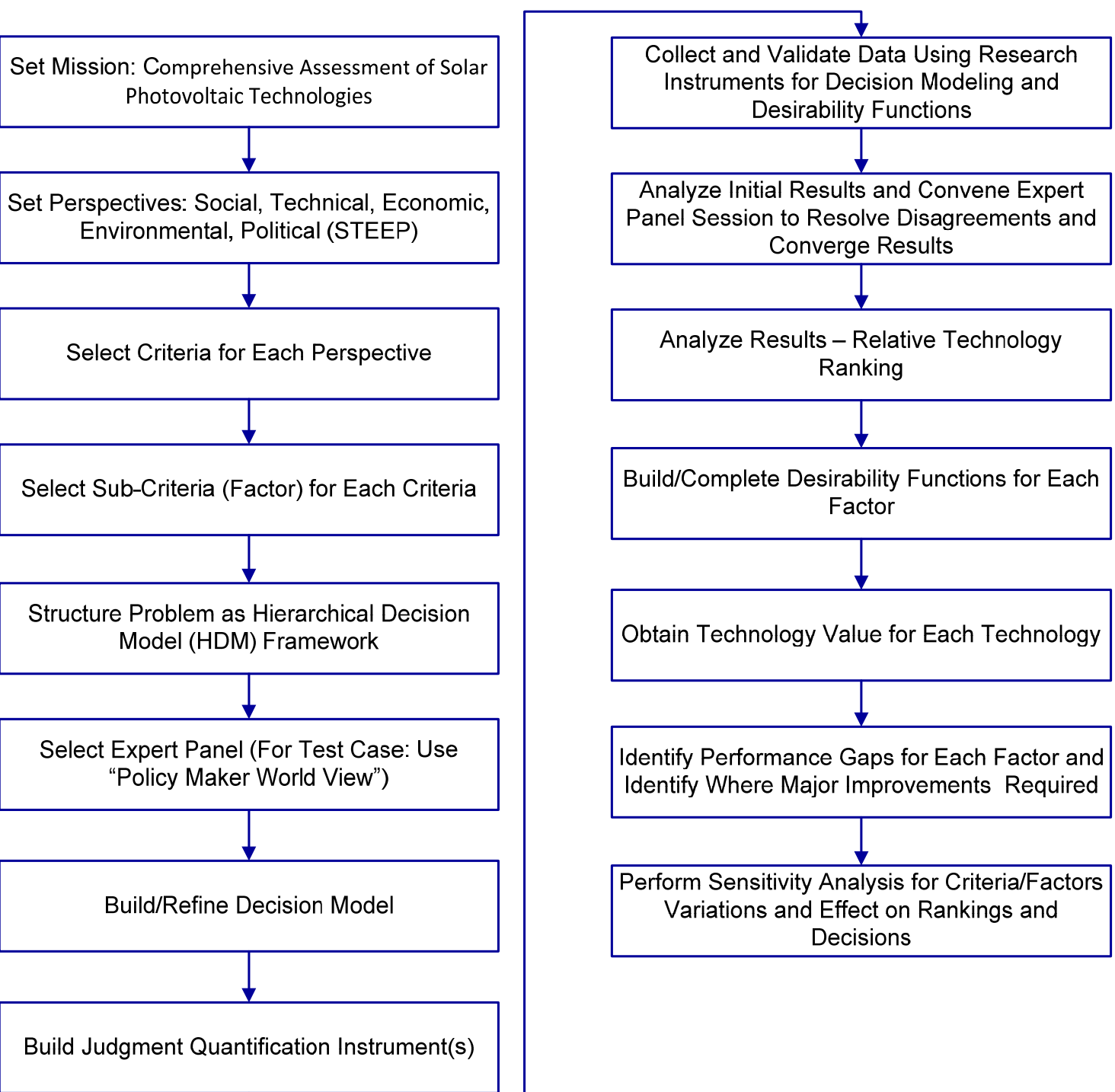

Figure 7: Decision Modeling Process 


\subsubsection{Defining the Hierarchical Decision Model}

The objectives, perspectives, criteria, and HDM modeling consist of the following:

- Mission. The ultimate goal of the decision model is to help with a comprehensive assessment of photovoltaic technologies.

- STEEP Perspectives. To fulfill the mission, the five perspectives (social, technical, economic, environmental, and political) are considered important. These are also the important considerations for worldviews of a technology supplier/developer, power utility or service provider, or government policy maker.

- Criteria and Factors for Each STEEP Perspective. For this modeling "criteria" are considered to be high-level criteria that encompass factors. For example, the criterion "health \& safety" refers to a mix of factors such as: public safety; work safety; hazardous health effects (accidental, long-term); and investment in health of society (indirect). The criteria and factors for each perspective are considered in the pairwise comparison for expert judgment quantification. Experts address their area of expertise with respect to a specific perspective. For example, social scientists compare and evaluate the social perspective and renewable energy technologists only focus on the technical perspective.

- HDM Model. An initial HDM model framework is shown in Figure 8 and includes the relations among mission, perspectives, and criteria. 
For example, a set of five candidate PV technologies were compared and ranked in this research. A judgment quantification instrument using pairwise comparisons was developed for data gathering from experts.

A more detailed, generalized model which includes the desirability function and resulting technology values is defined in Section 4.6. 


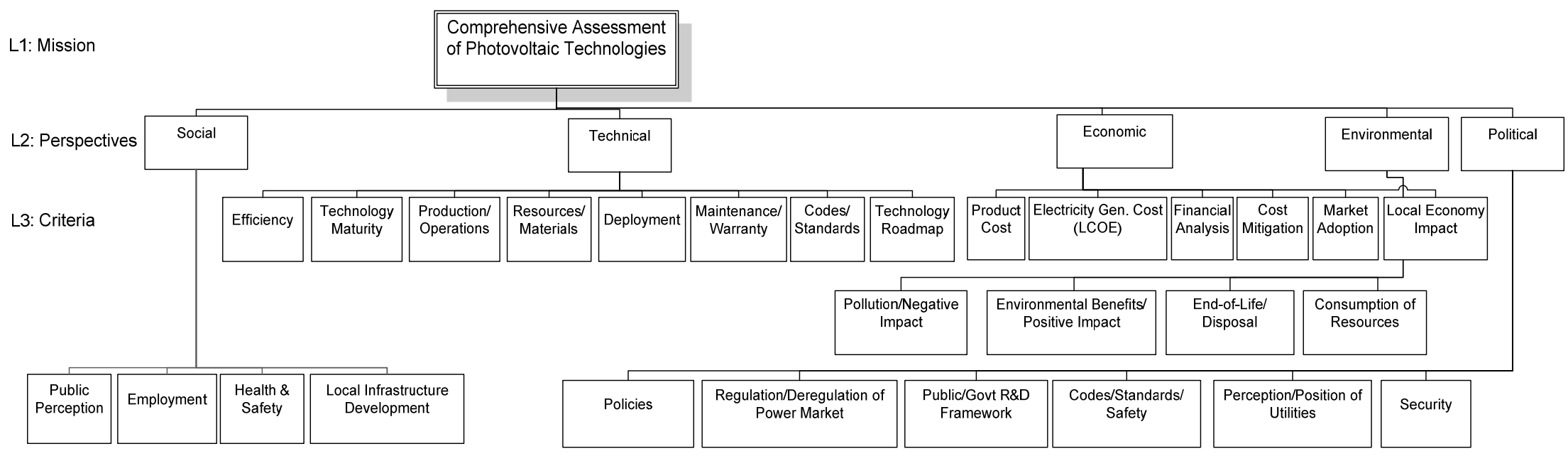

L4: Factors (Not Described)

L5: Alternatives - Sample Target PV Technologies C-Si (SJ) C-Si (MJ)
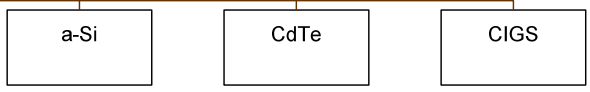

Figure 8: An Initial Hierarchical Decision Model Framework 


\subsubsection{Stage 2: Expert Panel Selection}

This research study requires the identification, selection, and formation of six expert panels for judgment solicitation to represent the five STEEP perspectives and the toplevel decision makers. The expert panels review, finalize and validate the HDM and the associated perspectives, criteria, and factors. The expert panels also help build the desirability functions and provide desirability values for the candidate PV technologies.

The six expert panels include:

1) Decision makers (or their representatives) to rank the perspectives for a particular worldview.

2) Social scientists to rank the contribution of each criterion and sub-criterion (called "factors") to the social perspective.

3) Technologists and engineers to rank the contribution of each criterion and factor to the technical perspective.

4) Economists to rank the contribution of each criterion and factor to the economic perspective.

5) Environmental scientists to rank the contribution of each criterion and factor to the environmental perspective.

6) Political scientists to rank the contribution of each criterion and factor to the political perspective. 
The general criteria for expert panel selection include:

1) Expertise in the topic

2) Balanced biases

3) A particular perspective - such as academic, user, and technology developer

4) Avoidance of dominance by "loudness" - because the study was conducted via emails and web quantification instruments and not face-to-face or group settings, this may be naturally the case.

5) Avoidance of silent bystanders - because the study will be conducted via emails and web quantification instruments and not face-to-face or group settings, this may be naturally the case.

The process and options of identifying experts for the panel are detailed in Section 4.4.

\subsubsection{Stage 3: Data Acquisition and Validation}

This stage involves the gathering of quantified judgments from the experts and analysis of the contributions of criteria and factors for ranking of each technology with respect to each perspective. Different worldviews such as technology supplier view and energy utility view can be considered in the model of this research but the focus is on the electric utility worldview for the prioritization of the perspectives.

The expert panels assisted in building the factor desirability functions for each element. The desirability functions defined the relationships between the level of 
performance of a technology and the relative value of that level to the user of the technology. It maps the performance metrics to a desirability scale in the 0 to 100 range, with 0 representing an unacceptable value and 100 representing the ideal desired value.

Three types of data were obtained from the experts:

1) Finalization of the HDM framework/structure which initially has 28 criteria and over 170 factors. The experts helped to reduce the number of factors and criteria to a more manageable size as well as validated them.

2) Judgment quantification from experts were obtained by pairwise comparisons to explain the relative importance of elements at a particular level using the sum method as illustrated in the initial model and test case.

3) Desirability functions were derived for each factor by determining the relationship of the performance level to its desirability. Experts were asked to develop the relation which may be linear or non-linear. This was performed through another judgment quantification instrument. When the HDM does not have any factors for a criterion, then the desirability functions were for that criterion itself. The experts were then requested to assist in providing the expected performance metrics for each candidate technology. 


\subsubsection{Stage 4: Analysis of the Results}

The judgment quantification resulting from the expert panels provided the ranking and relative rank values of the perspectives, criteria, and factors. These combined with the desirability function values for the metrics associated with the factors for each technology alternative resulted in a "technology value" for the PV technologies under consideration. Again, in the reduced case where there were no factors under a criterion, the desirability value was associated with that criterion.

At intermediate levels, the "technology values" identified "gap-from-the-best-level" and where effort is required for major improvements.

Since experts expressed judgments, inconsistencies and disagreements outside of the acceptable range did occur on a few instances. In such cases the experts were contacted to review their judgments and the judgment quantification instrument was re-applied. The analysis and management of disagreements amongst experts is detailed in Section 4.5.

\subsubsection{Stage 5: Sensitivity Analysis}

In this final stage the effect of the variation in perspectives, criteria, and factors were analyzed to determine the effect on the ranking and decision of the PV technology alternative being considered. 
This part of the research was based on the HDM sensitivity analysis (HDM-SA) research by Hongyi Chen and Dundar Kocaoglu [74]. The impact of any variation in the value of an element or any combination of elements in the decision hierarchy on the final decision was calculated. The tolerance limits in which the decision will remain the same were determined by this analysis.

\subsection{Expert Identification and Selection}

\subsubsection{Eliciting Expert Judgment: Background}

An expert is a specially trained individual who has background and experience in specific subject matter. He or she is recognized as one who is qualified to answer questions or address problems. Expert judgment may be expressed in the following statement:

"Expert judgment is data given by an expert in response to a technical problem."[75]

Expert judgment has also been stated as an expression of opinion based on the knowledge and experience experts make in responding to problems [76].

Expert judgment can be used in multiple ways such as [75]:

- Providing insights into new or complex phenomena

- Forecasting of future events or developments 
- Analyzing or interpreting qualitative or quantitative data

- Meta-cognition or understanding how experts solve problems or a group decision making process

- Exchanging knowledge and determining what is important

The typical expert judgment elicitation process is as follows (based on [75]):

1) Selection, structuring, and refinement of questions - categories and specific questions

2) Selection and motivation of experts

3) Selection and design of building blocks of elicitation to fit a target application. The building blocks are:

a. Elicitation method - e.g. verbal report, judgment quantification instrument

b. Communication mode - e.g. face-to-face, email, telephone, web-based survey

c. Elicitation situation - e.g. individual, interactive group, Delphi

d. Response mode - e.g. pair wise comparisons, ranks or ratings

e. Aggregation scheme (combining answers of multiple experts) - e.g. behavioral, mathematical

4) Elicitation practice (in-house or with pseudo-experts)

5) Elicitation and documentation of expert judgments - answers and related information. To answer, the expert will step through four cognitive tasks: 

a. Listen to or read and understand the question
b. Remember the relevant information
c. Make judgments
d. Formulate and articulate an answer

Typically, six to twelve experts are needed per study [77]. Beyond twelve experts the benefits of additional experts do not have a significant increase. In this proposal elicitation is via judgment quantification instruments using pairwise comparison of perspectives, criteria, and factors. The general communication mode is via email or a web-based application. New software developed by the ETM department will be used for judgment quantification.

\subsubsection{Identifying Experts for the Panel}

The author identified nine methods for expert identification and these are described in Table 5 below.

Table 5: Comparison of Methods for Expert Identification

\begin{tabular}{|c|c|c|c|}
\hline $\begin{array}{l}\text { Identification } \\
\text { Method }\end{array}$ & Description & Advantages & Disadvantages \\
\hline $\begin{array}{l}\text { Snowball } \\
\text { Sampling }\end{array}$ & $\begin{array}{l}\text { A common expert identification } \\
\text { involves experts naming other } \\
\text { experts. In specialized fields such as } \\
\text { solar photovoltaics, renewable } \\
\text { energy, social impact assessment } \\
\text { the experts are typically acquainted } \\
\text { with other experts in the same } \\
\text { field. A researcher begins with a }\end{array}$ & $\begin{array}{l}\text { Enables researcher } \\
\text { to reach an expert } \\
\text { population easily } \\
\text { This method is } \\
\text { simples and cost } \\
\text { efficient } \\
\text { This method } \\
\text { requires minimal }\end{array}$ & $\begin{array}{l}\text { Researchers have } \\
\text { little control over } \\
\text { the identification } \\
\text { process and rely on } \\
\text { the previous } \\
\text { subject matter } \\
\text { experts } \\
\text { Strong sampling }\end{array}$ \\
\hline
\end{tabular}




\begin{tabular}{|c|c|c|c|}
\hline & $\begin{array}{l}\text { few known experts, asks for more } \\
\text { names from them, and repeats until } \\
\text { he or she has more names than are } \\
\text { actually needed. This approach is } \\
\text { known as snowball sampling or } \\
\text { chain referral sampling [78-80]. } \\
\text { Researchers use this method to } \\
\text { obtain knowledge or data from } \\
\text { extended associations that have } \\
\text { been developed over time and } \\
\text { where there is no easy direct } \\
\text { access. } \\
\text { One common criticism is that the } \\
\text { results may be skewed if experts } \\
\text { are mainly selected from the same } \\
\text { organization or class of } \\
\text { organizations such as academia, } \\
\text { industry, government, or regional } \\
\text { affiliations [75]. To overcome this } \\
\text { disadvantage a balanced group of } \\
\text { experts across multiple classes of } \\
\text { organization is recommended. }\end{array}$ & $\begin{array}{l}\text { planning and people } \\
\text { [81] }\end{array}$ & $\begin{array}{l}\text { bias may creep in } \\
\text { since initial experts } \\
\text { will tend to } \\
\text { nominate other } \\
\text { exerts with whom } \\
\text { they have close } \\
\text { associations may } \\
\text { tend to share } \\
\text { similar traits and } \\
\text { characteristics [81] }\end{array}$ \\
\hline $\begin{array}{l}\text { Citation } \\
\text { Analysis }\end{array}$ & $\begin{array}{l}\text { Using Citation Databases-Science } \\
\text { Citation Index Expanded (SCl- } \\
\text { EXPANDED), Social Sciences } \\
\text { Citation Index (SSCI), and Arts \& } \\
\text { Humanities Citation Index } \\
\text { (A\&HCI) - to determine expertise } \\
\text { based on papers published and } \\
\text { referenced is good method to } \\
\text { identify experts. Associated } \\
\text { reporting and analysis also enables } \\
\text { grouping the authors into specialty } \\
\text { areas [82] }\end{array}$ & $\begin{array}{l}\text { Structured evidence } \\
\text { based method to } \\
\text { identify experts who } \\
\text { have produced } \\
\text { scholarly works }\end{array}$ & $\begin{array}{l}\text { Limited to formal } \\
\text { (scientific) } \\
\text { literature and } \\
\text { bibliometrics } \\
\text { Does not cover } \\
\text { experiential } \\
\text { knowledge/experti } \\
\text { se well. For } \\
\text { industry experts } \\
\text { one may need to } \\
\text { target trade } \\
\text { associations, } \\
\text { conferences, and } \\
\text { journals. }\end{array}$ \\
\hline $\begin{array}{l}\text { Social } \\
\text { Network } \\
\text { Analysis }\end{array}$ & $\begin{array}{l}\text { Social network analysis (SNA) refers } \\
\text { to methods of analyzing social } \\
\text { networks or structures. The } \\
\text { networks consist of nodes (e.g. } \\
\text { experts) which connect via } \\
\text { interdependencies (e.g. common } \\
\text { expert knowledge). } \\
\text { There are two common } \\
\text { approaches: personal profiling and } \\
\text { document profiling. In personal } \\
\text { profiling the search keywords } \\
\text { describe the person. This is the } \\
\text { most common approach. In }\end{array}$ & $\begin{array}{l}\text { Structured method } \\
\text { to describe } \\
\text { knowledge flows } \\
\text { and interactions to } \\
\text { find experts }\end{array}$ & $\begin{array}{l}\text { Requires learning } \\
\text { SNA tools, defining } \\
\text { and collecting } \\
\text { input data, and } \\
\text { may require } \\
\text { surveys }\end{array}$ \\
\hline
\end{tabular}




\begin{tabular}{|c|c|c|c|}
\hline & $\begin{array}{l}\text { document profiling, keywords are } \\
\text { used for document searches. The } \\
\text { experts are then derived from the } \\
\text { frequency of occurrence in the } \\
\text { documents. This takes longer to } \\
\text { find the expert but is more accurate } \\
\text { [83]. } \\
\text { There are multiple software tools } \\
\text { for SNA such as UCINET and } \\
\text { MultiNet. }\end{array}$ & & \\
\hline Wikipedia & $\begin{array}{l}\text { A well established knowledge } \\
\text { repository is Wikipedia. Authors of } \\
\text { Wikipedia pages and the experts } \\
\text { referred by them may all be } \\
\text { considered. Gianluca Demartini } \\
\text { describes how his research can be } \\
\text { effective in finding experts using } \\
\text { Wikipedia [84]. }\end{array}$ & $\begin{array}{l}\text { This is free and easy } \\
\text { to access }\end{array}$ & $\begin{array}{l}\text { The work of finding } \\
\text { "true" experts is } \\
\text { still in research } \\
\text { phase }\end{array}$ \\
\hline $\begin{array}{l}\text { Academic } \\
\text { Sources }\end{array}$ & $\begin{array}{l}\text { Certain academic websites have a } \\
\text { searchable database of professors } \\
\text { claiming expertise such as } \\
\text { http://news.uns.purdue.edu/news } \\
\text { web.experts.html [85]. A } \\
\text { background of a professor can be } \\
\text { verified at the academic } \\
\text { institution's website. Professors } \\
\text { typically include their resume, } \\
\text { papers published and courses } \\
\text { offered. }\end{array}$ & $\begin{array}{l}\text { This is an easy } \\
\text { method to identify } \\
\text { experts }\end{array}$ & $\begin{array}{l}\text { The experts are } \\
\text { limited to } \\
\text { professors and the } \\
\text { U.S. } \\
\text { Only those experts } \\
\text { that registered } \\
\text { with the database } \\
\text { will be considered }\end{array}$ \\
\hline $\begin{array}{l}\text { Google } \\
\text { Groups } \\
\text { (or other web } \\
\text { site } \\
\text { discussion } \\
\text { groups such } \\
\text { as Linkedln } \\
\text { groups) }\end{array}$ & $\begin{array}{l}\text { Discussion group messages include } \\
\text { blogs or discussions by experts or } \\
\text { referring to them. Google Groups- } \\
\text { http://groups.google.com/, } \\
\text { formerly Usenet- has about } 10 \\
\text { trillion posts per day (source: } \\
\text { altopia.com) [85]. }\end{array}$ & $\begin{array}{l}\text { This is free and easy } \\
\text { to access }\end{array}$ & $\begin{array}{l}\text { Identifying } \\
\text { scholarly or well- } \\
\text { recognized experts } \\
\text { may require } \\
\text { further verification }\end{array}$ \\
\hline $\begin{array}{l}\text { Google } \\
\text { Advanced } \\
\text { Searches }\end{array}$ & $\begin{array}{l}\text { Typing in an expert's name may } \\
\text { result in related conferences or } \\
\text { discussion groups which may lead } \\
\text { to finding other experts. Google (or } \\
\text { its scholarly search variant-Google } \\
\text { Scholar) is recognized as the best } \\
\text { search engine to use for this } \\
\text { purpose. }\end{array}$ & $\begin{array}{l}\text { This is free and easy } \\
\text { to access }\end{array}$ & $\begin{array}{l}\text { Requires a lot of } \\
\text { "manual } \\
\text { searching" }\end{array}$ \\
\hline $\begin{array}{l}\text { Expert } \\
\text { Witness } \\
\text { National }\end{array}$ & $\begin{array}{l}\text { Law.com has an expert database } \\
\text { http://experts.law.com/ which is } \\
\text { free to users. However experts }\end{array}$ & $\begin{array}{l}\text { Experts are ready to } \\
\text { consult }\end{array}$ & $\begin{array}{l}\text { Expert witnesses } \\
\text { charge high fees }\end{array}$ \\
\hline
\end{tabular}




\begin{tabular}{|llll|}
\hline Database & $\begin{array}{l}\text { have to pay an annual fee that } \\
\text { varies depending on the type of } \\
\text { listing-national or by state. }\end{array}$ & \\
\hline Trade & $\begin{array}{l}\text { Industry experts tend to be } \\
\text { members of trade association, } \\
\text { publish articles in trade journals, } \\
\text { and attend trade-specific } \\
\text { conferences. }\end{array}$ & $\begin{array}{l}\text { Industry or trade } \\
\text { specific experts can } \\
\text { be identified }\end{array}$ & $\begin{array}{l}\text { Typically, limited to } \\
\text { the industry and } \\
\text { government }\end{array}$ \\
\end{tabular}

Comparing the methods indicated that was best to use the snowball sampling method together with citation analysis to provide a broad panel of experts-from academia, industry, and government for the Solar PV STEEP decision modeling. Snowball sampling provides easy access to expert populations and is easy to apply. Having experts from different class of organizations such as academia, industry, government, or regional overcomes the disadvantage of having a built-in bias of a particular class of organization. This can be supplemented with the citation analysis approach to validate the experts (or at least the first seed experts) or find experts that were missing from the snowball approach. (The last line of defense was to tap into trade associations if experts were still missing from the previous two methods.) The objective was to start with Portland State University professors who have deep connections with industry and government. The professors represented the following departments and STEEP perspectives:

- Urban Studies and Planning (Social)

- Engineering (Technical)

- Economics (Economic)

- Environmental Science (Environmental) 
- Political Science (Political) 


\subsection{Analyzing Disagreements among Experts}

\subsubsection{Disagreements among Experts: Background}

This research used multiple panels of experts for judgment elicitation. The experts responded to a judgment quantification instrument and the panel's judgment was aggregated. This aspect of the research is fundamental for the decision making model [75]. The experts have to generally agree on the outcome since this is a consensus decision making process. However, there can be disagreements of opinions and judgments between the experts. The disagreements may be due to multiple reasons including [75]:

- Experts do not retain the same knowledge. The expert's body of knowledge has been created over a period of time through his or her professional experiences such as education, training, research, and experiential exposures. Also, the way experts process information (for example, apply problem solving) may be different. Since we are dealing with human beings there may be societal and cultural differences. Hence, different backgrounds can result in disagreements.

- Expert judgment is sought in exploratory areas where there are no clear theories or practices. The judgments may be predictive.

- Experts are provided insufficient information or guidelines so they make inherent (or implicit) judgments about the missing data or gaps in information. Hence, it is important that the expert panels are provided good a priori 
briefings and explanations so the experts have good sound information before they answer the judgment quantification instrument. They should be encouraged to ask questions and resolve doubts and concerns early.

\subsubsection{Analyzing Disagreements}

One frequently used method to obtain expert judgment from a group consensus is the Delphi Method. This involves the experts reaching a consensus iteratively. The experts provide their judgment and the panel results are sent to the panel as a summary. Then another round of judgment elicitation is performed which includes the revised judgment of the experts based on the previous summary. The revisions (if needed) may be due to clarifications or better understanding of the questions. This process is repeated until a pre-determined consensus level is reached through a reduction in disagreements.

In the HDM analysis there are two measures for validating the results: inconsistency and disagreement. Inconsistency is related to an individual expert's response to the judgment quantification instrument and it is generally accepted that the Inconsistency Index should be less than 0.10 for valid results. Inconsistency will not be discussed in this section since the focus is on analyzing the disagreement between the experts. [It should be noted that inconsistency and disagreement are independent of each other. 
An expert may be consistent and yet in disagreement with other experts or group of experts.]

Analyzing and resolving disagreements among the experts is an important aspect of the research. This requires the identification of the expert(s) who is (are) not in agreement with the group and having informational sessions to understand the differences. Furthermore, a rigorous approach is required to arrive at an acceptable level of disagreement. In this section, two statistical methods to measure disagreement (or agreement) level between experts will be discussed: (1) Intraclass Correlation Coefficient (ICC or $r_{\text {ic }}$ ) and (2) F-test with Hypotheses Testing. The Intraclass correlation coefficient (ICC) is detailed in the next section. ICC provides a guideline to interpret the degree to which all judges agree in the range of zero to one (with zero (0) implying absolute disagreement and a one (1) indicating maximum agreement). Shrout and Fleiss enhanced ICC evaluation by using an F-test to determine whether or not there is absolute disagreement among the judges (i.e. ICC is calculated to be zero) [86]. To perform the F-test, the null hypothesis represents no correlation among the experts.

To illustrate the disagreement analysis, data from judgment quantification instrument obtained in one of the author's independent studies is used. (The author was unable to find data reflecting strong disagreements amongst the experts from the independent studies, however, the approach and analysis applies for agreements and 
disagreements to ensure that the results of the expert panel's judgments are valid.)

The example HDM model and the PCM table for the objectives (level- 2 criteria) that contribute to the level-1 mission are shown in and Figure 9. PCM is a software tool to measure and analyze judgment quantification and was developed by the ETM department. The PCM table in Figure 9 shows the relative ranking of four criteria as judged by six experts. (It also shows level of inconsistency for each expert.)

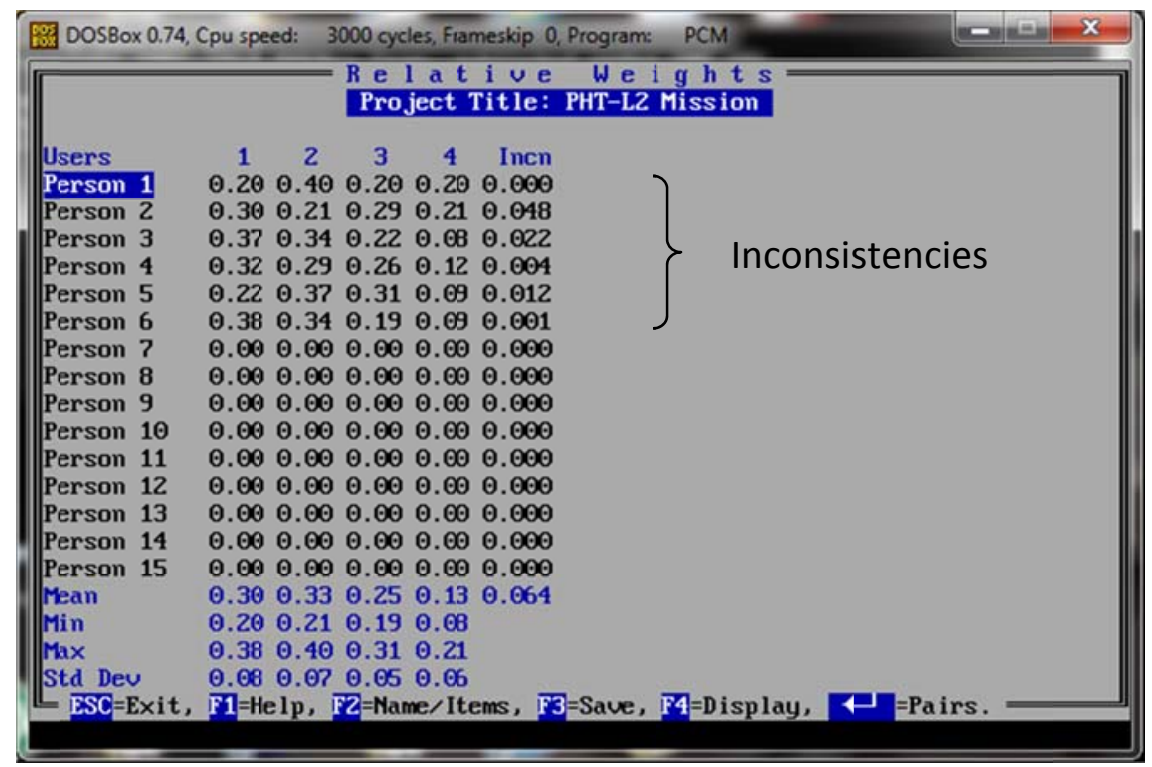

Figure 9: Example PCM Expert Judgment Results Table

\subsubsection{Intraclass Correlation Coefficient (ICC)}

In statistics the intraclass correlation coefficient (ICC) is a descriptive measure used when quantitative measurements are made on units that are organized into groups (for example, a panel of experts). It describes how strongly units in the same group resemble each other. ICC or $r_{\text {ic }}$ represents the degree to which $\mathrm{k}$ judges (or experts) are in agreement with one another on the scores (or relative importance in value) of $n$ 
subjects (or criteria/factors in this case). The following Table 6 characterizes ICC or $r_{\text {ic }}$ [87].

Table 6: Intraclass Correlation Coefficient (ICC) Characteristics

\begin{tabular}{|c|c|c|}
\hline $\begin{array}{l}\text { ICC } \\
\text { Char- } \\
\text { acteristic }\end{array}$ & Description & Comments / Formulas \\
\hline Range & $-\frac{1}{(k-1)}<r_{i c}<+1$ & $\begin{array}{l}r_{i c}=I C C \\
k=\text { number of judges (experts) } \\
n=\text { number of subjects (criteria) }\end{array}$ \\
\hline Values & $\begin{array}{l}r_{i c}=1 \quad-\text { When all judges in agreement } \\
r_{i c}=0 \quad-\text { When judges are in maximum } \\
\text { disagreement } \\
r_{i c}>=0-\text { Higher } r_{i c} \text { values indicate higher } \\
\text { agreement level }\left[r_{i c}>0.7 \text { is considered strong }\right. \\
\text { agreement }]\end{array}$ & If $r_{i c}<0$ then it is considered as 0 \\
\hline
\end{tabular}




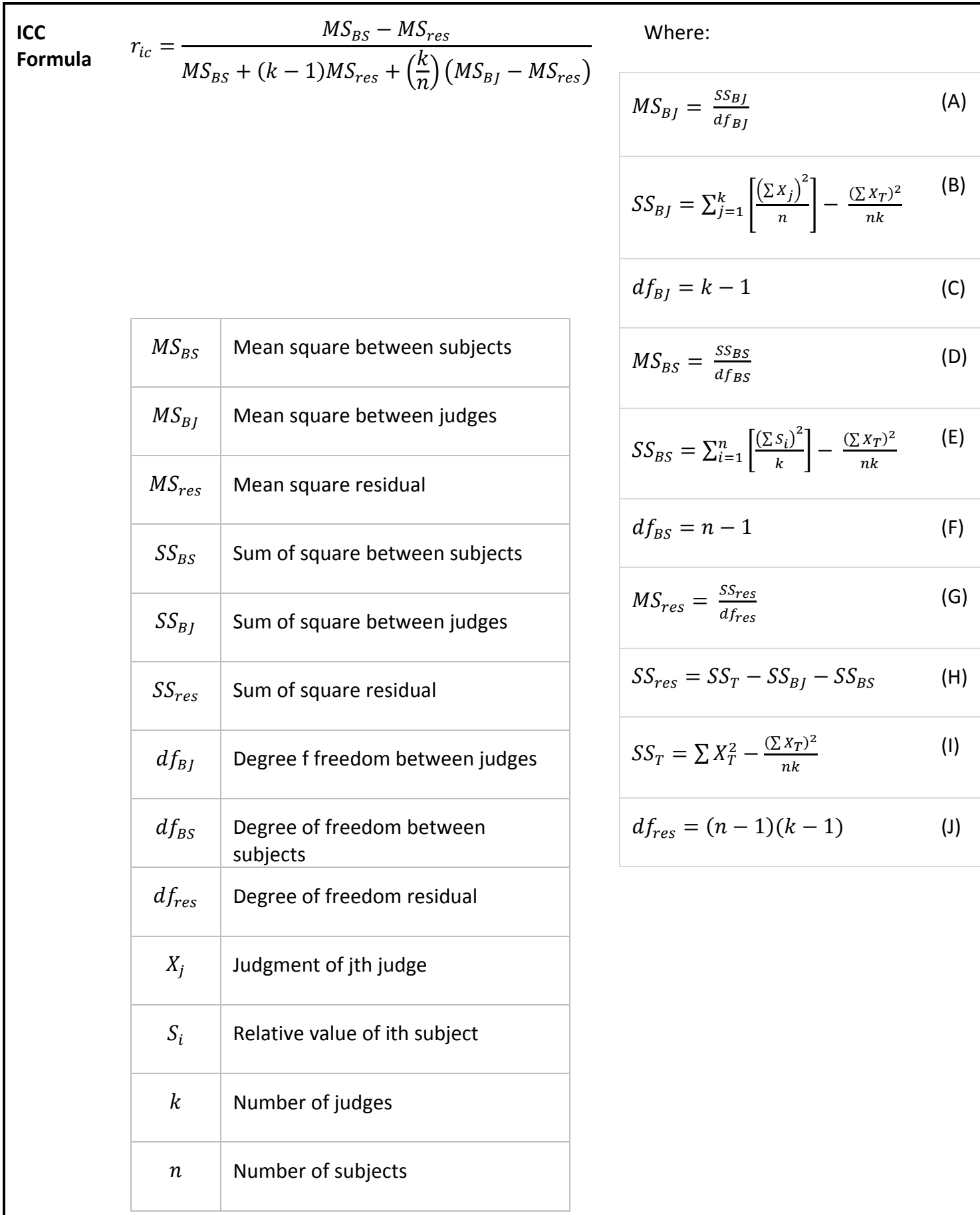




\subsubsection{F-Test with Hypothesis Testing}

The hypothesis tests for disagreement among judges (or experts) are described in

Table 7 below.

Table 7: F-Test Characteristics

\begin{tabular}{|c|c|c|c|}
\hline F-Test Characteristics & \multicolumn{3}{|l|}{ Description } \\
\hline Null Hypothesis & $\mathrm{H}_{0}: \mathrm{r}_{\mathrm{ic}}=0$ & \multicolumn{2}{|c|}{$\begin{array}{l}\text { There is disagreement (i.e. there is no correlation } \\
\text { of the judgments by judges on the subjects) }\end{array}$} \\
\hline Alternative Hypothesis & $\mathrm{H}_{\mathrm{a}}: \mathrm{r}_{\mathrm{ic}}>0$ & \multicolumn{2}{|c|}{$\begin{array}{l}\text { There is statistically significant evidence that there } \\
\text { is some level of agreement [Alternative } \\
\text { Hypothesis] }\end{array}$} \\
\hline \multirow[t]{3}{*}{ F-Value } & \multirow{3}{*}{$F_{B S}=\frac{M S_{B S}}{M S_{\text {res }}}$} & & \\
\hline & & $M S_{B S}$ & Mean square between subjects \\
\hline & & $M S_{\text {res }}$ & Mean square residual \\
\hline \multirow[t]{2}{*}{ F-Critical } & \multicolumn{3}{|c|}{$\begin{array}{l}\text { The critical F-value the statistic must exceed to reject the test. In this } \\
\text { case a significance level of } 5 \%(\alpha=0.05) \text { is considered. }\end{array}$} \\
\hline & \multicolumn{3}{|c|}{$\begin{array}{l}\text { [An } \alpha \text { of } 0.05 \text { indicates that there is only one chance in twenty that } \\
\text { this event happened by coincidence and a } 0.05 \text { level of statistical } \\
\text { significance is being implied. The lower the significance level, the } \\
\text { stronger the evidence required. It is conventional to use a } 5 \% \text { level of } \\
\text { significance for many applications.] }\end{array}$} \\
\hline Hypothesis Test & \multicolumn{3}{|c|}{ If $F_{B S}>F_{\text {critical }}$ at $\alpha=0.05 t$ en $H_{0}$ is rejected } \\
\hline
\end{tabular}

\subsubsection{Example with ICC and F-Test Calculations}

The section steps through the calculations for calculating $r_{i c}$ for the example shown above using the PCM calculation tool with six judges (or experts; $\mathrm{j}_{\mathrm{j}}, \mathrm{j}=1-6, \mathrm{k}=6$ ) and 4 subjects (or criteria; $\mathrm{S}_{\mathrm{i}}, \mathrm{i}=1-4, \mathrm{n}=4$ ). This is depicted in and Table 9.

The F-test calculations are shown in Table 10 and 
Table 11 and the results indicate that the null hypothesis cannot be rejected and hence the results are acceptable at a statistical significance level of 0.05 (or a confidence level of $95 \%)$.

Table 8: Deriving Sums and Means for ICC Example - Intermediate Step

\begin{tabular}{|c|c|c|c|c|c|c|c|c|c|c|c|c|c|c|c|}
\hline $\mathrm{S}_{\mathrm{i}} / \mathrm{J}_{\mathrm{j}}$ & \multicolumn{2}{|c|}{ J1 } & \multicolumn{2}{|c|}{ J2 } & \multicolumn{2}{|c|}{ J3 } & \multicolumn{2}{c|}{ J4 } & \multicolumn{2}{|c|}{ J5 } & \multicolumn{2}{|c|}{ J6 } & \multicolumn{3}{|c|}{ Sums } \\
\hline & $\mathrm{X}_{1}$ & $\mathrm{X}_{1}^{2}$ & $\mathrm{X}_{2}$ & $\mathrm{X}_{2}^{2}$ & $\mathrm{X}_{3}$ & $\mathrm{X}_{3}^{2}$ & $\mathrm{X}_{4}$ & $\mathrm{X}_{4}^{2}$ & $\mathrm{X}_{5}$ & $\mathrm{X}_{5}^{2}$ & $\mathrm{X}_{6}$ & $\mathrm{X}_{6}^{2}$ & $\Sigma \mathrm{S}_{\mathrm{i}}$ & $\Sigma \mathrm{X}_{\mathrm{T}}$ & $\Sigma \mathrm{X}_{\mathrm{T}}^{2}$ \\
\hline $\mathrm{S} 1$ & 0.20 & 0.04 & 0.30 & 0.09 & 0.37 & 0.14 & 0.32 & 0.10 & 0.22 & 0.05 & 0.38 & 0.14 & 1.79 & \\
$\mathrm{~S} 2$ & 0.40 & 0.16 & 0.21 & 0.04 & 0.34 & 0.12 & 0.29 & 0.08 & 0.37 & 0.14 & 0.34 & 0.12 & 1.95 & \\
\hline $\mathrm{S} 3$ & 0.20 & 0.04 & 0.29 & 0.08 & 0.22 & 0.05 & 0.26 & 0.07 & 0.31 & 0.10 & 0.19 & 0.04 & 1.47 & \\
\hline $\mathrm{S} 4$ & 0.20 & 0.04 & 0.21 & 0.04 & 0.08 & 0.01 & 0.12 & 0.01 & 0.09 & 0.01 & 0.09 & 0.01 & 0.79 & \\
\hline Mean & 0.25 & & 0.25 & & 0.25 & & 0.25 & & 0.25 & & 0.25 & & & & \\
\hline$\Sigma \mathrm{X}_{\mathrm{j}}$ & 1.00 & & 1.01 & & 1.01 & & 0.99 & & 0.99 & & 1.00 & & & 6.00 \\
\hline$\Sigma \mathrm{X}_{\mathrm{j}}^{2}$ & & 0.28 & & 0.26 & & 0.31 & & 0.27 & & 0.29 & & 0.30 & & & 1.71 \\
\hline
\end{tabular}




$$
\begin{aligned}
& \mathrm{n}=4, \mathrm{k}=6 \\
& S S_{B J}=\sum_{j=1}^{k}\left[\frac{\left(\sum X_{j}\right)^{2}}{n}\right]-\frac{\left(\sum X_{T}\right)^{2}}{n k}=\left(6 \times \frac{1^{2}}{4}\right)-\frac{6^{2}}{4 \times 6}=0 \\
& d f_{B J}=k-1=6-1=5 \\
& M S_{B J}=\frac{S S_{B J}}{d f_{B J}}=\frac{0}{5}=0 \\
& S S_{B S}=\sum_{i=1}^{n}\left[\frac{\left(\sum S_{i}\right)^{2}}{k}\right]-\frac{\left(\sum X_{T}\right)^{2}}{n k}=\left(\frac{1.79^{2}}{6}+\frac{1.95^{2}}{6}+\frac{1.47^{2}}{6}+\frac{0.79^{2}}{6}\right)-\frac{6^{2}}{(4 \times 6)}=0.13 \\
& d f_{B S}=n-1=4-1=3 \\
& M S_{B S}=\frac{S S_{B S}}{d f_{B S}}=\frac{0.13}{3}=0.04 \\
& S S_{T}=\sum X_{T}^{2}-\frac{\left(\sum X_{T}\right)^{2}}{n k}=1.71-\frac{6^{2}}{4 \times 6}=0.21 \\
& S S_{\text {res }}=S S_{T}-S S_{B J}-S S_{B S}=0.21-0-0.13=0.08 \\
& d f_{\text {res }}=(n-1)(k-1)=(4-1)(6-1)=15 \\
& M S_{\text {res }}=\frac{S S_{\text {res }}}{d f_{\text {res }}}=\frac{0.08}{15}=0.005 \\
& r_{i c}=\frac{M S_{B S}-M S_{r e s}}{M S_{B S}+(k-1) M S_{r e s}+\left(\frac{k}{n}\right)\left(M S_{B J}-M S_{r e s}\right)} \\
& =\frac{0.04-0.005}{0.04+(6-1) \times 0.005+\left(\frac{6}{4}\right) \times(0-0.005)}=0.61
\end{aligned}
$$


Table 10: F-Test Hypothesis Testing Calculations

[Also refer to Table 6, Table 7, Table 8, and Table 9.]

\begin{tabular}{|l|c|c|c|c|}
\hline Variation & $\begin{array}{l}\text { Sum of } \\
\text { Squares }\end{array}$ & $\begin{array}{c}\text { Degree of } \\
\text { Freedom }\end{array}$ & \multicolumn{2}{c|}{$\begin{array}{c}\text { Mean } \\
\text { Square }\end{array}$} \\
\hline $\begin{array}{l}\text { Between } \\
\text { Subjects/Criteria (BS) }\end{array}$ & 0.13 & 3 & 0.04 & $F_{B S}=\frac{M S_{B S}}{M S_{\text {res }}}=\frac{0.04}{0.005}=8$ \\
\hline $\begin{array}{l}\text { Between } \\
\text { Judges/Experts (BJ) }\end{array}$ & 0 & 5 & 0 & \\
\hline Residual (res) & 0.08 & 15 & 0.005 & \\
\hline
\end{tabular}

Table 11: F-Test: F-Critical Calculations and Conclusion of Expert Agreement

\begin{tabular}{|c|c|c|}
\hline \multicolumn{2}{|c|}{ Input Parameters } & F-Critical \\
\hline \multicolumn{2}{|c|}{$\begin{array}{l}d f_{\text {numerator }}=d f_{B S}=3 \\
d f_{\text {denominator }}=d f_{\text {res }}=1\end{array}$} & $\begin{array}{l}3.29 \\
\text { (Based on F-Distribution Function and Input } \\
\text { Parameters) }\end{array}$ \\
\hline \multicolumn{2}{|l|}{$p$-level $=\alpha=0.05$} & $F_{R C}=8>F_{\text {critical }}=3.29$ at $\alpha=0.05$ \\
\hline$d f_{\text {numerator }}$ & $\begin{array}{l}\text { Degree of freedom } \\
\text { (numerator) }\end{array}$ & $\begin{array}{l}\text { and } H_{0} \text { is rejected } \\
\text { Hence, group judgment quantification is }\end{array}$ \\
\hline$d f_{\text {denominator }}$ & $\begin{array}{l}\text { Degree of freedom } \\
\text { (denominator) }\end{array}$ & $\begin{array}{l}\text { accepted at } 0.05 \text { level due to expert } \\
\text { agreement. }\end{array}$ \\
\hline$p-$ level & Probability Level & \\
\hline
\end{tabular}

\subsubsection{Identification of Experts in Disagreement}

The statistical analysis using ICC and F-tests can reveal if there is statistically significant disagreement between the experts in the group. If a disagreement is found, another important aspect is to identify the experts who are in disagreement or agreement. For 
this a method such as the statistical process of Hierarchical Cluster Analysis (HCA) can be used. In HCA, a hierarchy or tree-like structure is constructed to observe the relationship among entities (for example, experts). This structure is called a dendrogram. HCA groups experts in clusters according to their similarity in judgment. Experts in different clusters are significantly different in their judgments. The largest cluster can be assigned as the base clusters and should contain the maximum number of experts. The smaller clusters will represent experts in disagreement with the base cluster. HCA calculates clusters of experts (called "cases") using the arithmetic distance between cases with the small distances representing clusters. Clusters are considered "far" from other clusters. Continuing with the earlier example for ICC and F-Test and with the use of statistical analysis software JMP Pro, the following Figure 10 and Figure 11 depict the expert judgment values and the resulting dendrogram.

In Figure 11 the dendrogram depicts the six experts on the vertical axis and the horizontal axis indicates the shows the distance between clusters when they are joined. Horizontal joining lines represent the distances among the clusters. In this example the dendrogram shows clusters close together (with maximum distance between clusters as 2.63) indicating no strong disagreements. At this level of granularity there are five clusters. For example Experts 3 and 6 are close together in their opinion and form one cluster (Cluster 5). In this example there is no large base cluster. In the case of strong disagreements the distance between the disagreeing expert and the base cluster(s) would be high, for example greater than 6.0. 


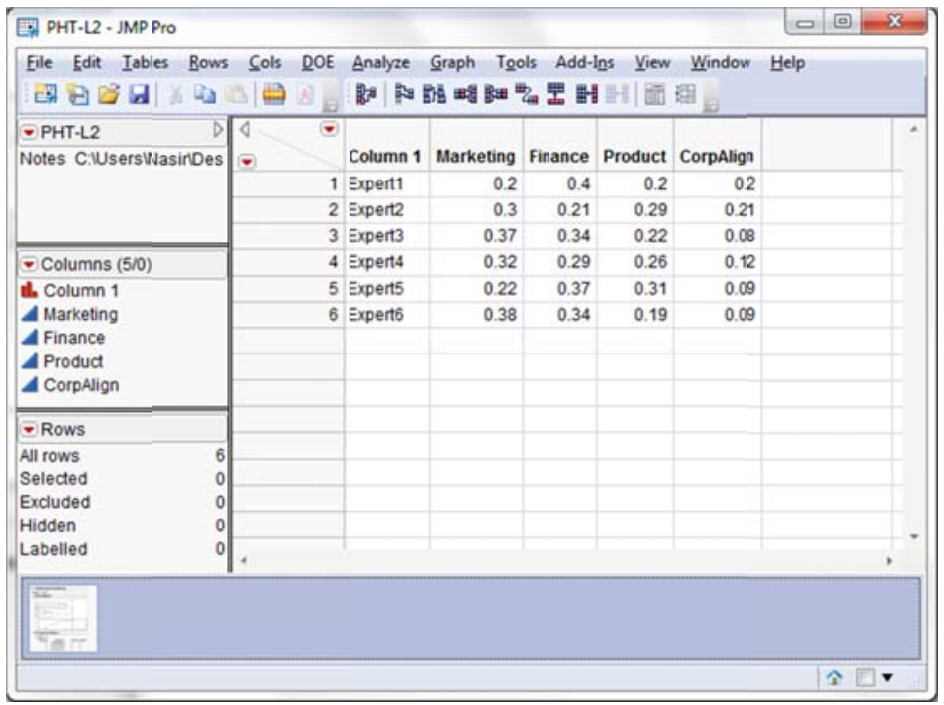

Figure 10: Expert Judgment Data input in JMP Pro

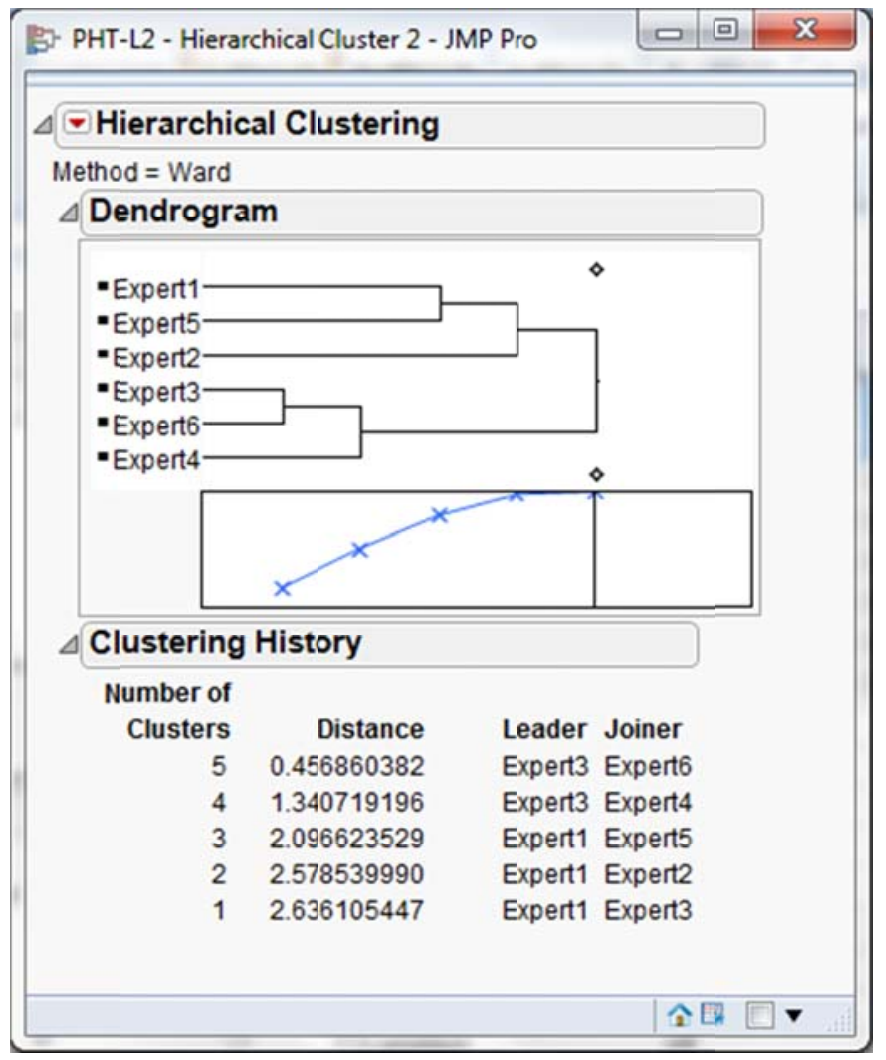

Figure 11: Hierarchical Cluster Analysis (HCA)/Dendrogram Example in JMP Pro 
Once the experts in disagreement have been identified the researcher needs to contact them to better understand the cause of disagreement. This can result in the retaking of the judgment quantification instrument or confirming the original judgment. In the latter case, if the disagreement is statistically significant more iteration steps may be necessary in the Delphi process to reach a consensus. 


\subsection{Generalized Hierarchical Decision Model for Technology Values}

\subsubsection{Hierarchical Decision Modeling for Renewable Energy Technology}

\section{Assessment: Background}

The Hierarchical Decision Model (HDM) in this proposal consists of five levels of hierarchy: mission, five perspectives, criteria, and factors as depicted in Figure 12.

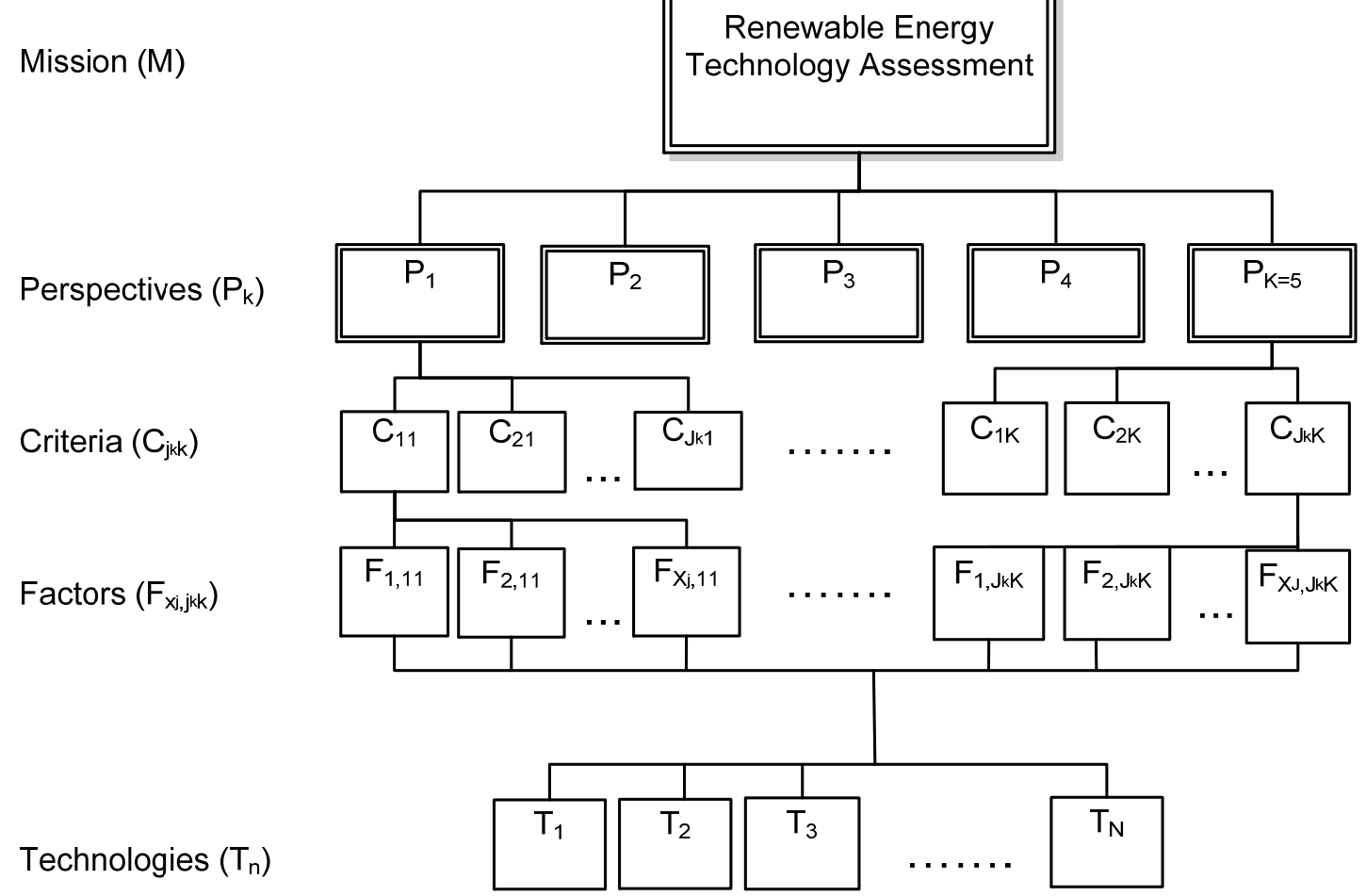

Figure 12: Generalized Hierarchical Decision Model for Renewable Energy Assessment of Technologies (Framework)

This model represents a hierarchical structure where the relative contribution of the technologies to the mission of assessing the best technology is calculated and 
analyzed. This is done by determining the following priorities and contributions and shown in Table 12 [88], [89]:

Table 12: Determining Priorities and Contributions at each HDM Level

\begin{tabular}{|c|c|c|c|}
\hline $\begin{array}{l}\text { HDM } \\
\text { Level }\end{array}$ & $\begin{array}{l}\text { Relative Priority / Contribution for } \\
\text { HDM }\end{array}$ & Measurement & Method \\
\hline Level-1 & $\begin{array}{l}\text { Mission for decision making on } \\
\text { renewable energy technology } \\
\text { assessment }\end{array}$ & & \\
\hline Level-2 & $\begin{array}{l}\text { Calculation of relative priorities of } \\
\text { the (five) perspectives to the } \\
\text { mission }\end{array}$ & $\begin{array}{l}\text { Expert judgment quantification } \\
\text { instrument using pairwise } \\
\text { comparison and allocation of } 100 \\
\text { points between two perspectives }\end{array}$ & Constant-sum \\
\hline Level-3 & $\begin{array}{l}\text { Calculation of relative importance } \\
\text { of the criteria to the perspectives }\end{array}$ & $\begin{array}{l}\text { Expert judgment quantification } \\
\text { instrument using pairwise } \\
\text { comparison and allocation of } 100 \\
\text { points between two criteria }\end{array}$ & Constant-sum \\
\hline Level-4 & $\begin{array}{l}\text { Calculation of relative importance } \\
\text { of the factors to the criteria }\end{array}$ & $\begin{array}{l}\text { Expert judgment quantification } \\
\text { instrument using pairwise } \\
\text { comparison and allocation of } 100 \\
\text { points between two factors }\end{array}$ & Constant-sum \\
\hline Level-5 & $\begin{array}{l}\text { Determination of the desirability } \\
\text { value for the associated technology } \\
\text { characteristic }\end{array}$ & Using desirability functions & \\
\hline
\end{tabular}

At a given level the relative component-perspectives, criteria, factors, or technologies-values are determined through pairwise comparisons using judgment quantification instruments and panels of experts. The results represent the value of the components with respect to the next higher level.

The last level uses an approach that has proven to be more suitable and is based on semi-absolute values instead of relative values. This involves the use of a composite 
index called "technology value" and desirability functions that represent each factor [88], [90]. With this method the generalized HDM model is also an operational model by replacing the technologies with a set of their physical or performance characteristics. These characteristics are then transformed into their desirability values. These are semi-absolute values. There are several methods to transform the characteristics to desirability values and will be discussed in the next section. The relative technology values are replaced by the desirability values and then used together with the relative ranking of the factors, criteria, and perspectives. The model is shown in Figure 13.

Mission (M)

Perspectives $\left(P_{k}\right)$

Criteria $\left(\mathrm{C}_{\mathrm{j} k \mathrm{k}}\right)$

Factors $\left(\mathrm{F}_{\mathrm{x}, \mathrm{jkk}}\right)$

Desirability Functions $\left(\mathrm{DF}_{\mathrm{x}, \mathrm{j}, \mathrm{kk}}\right)$

Technology Characteristics $\left(\mathrm{t}_{\mathrm{n}, \mathrm{x}, \mathrm{j} \text { kk }}\right)$

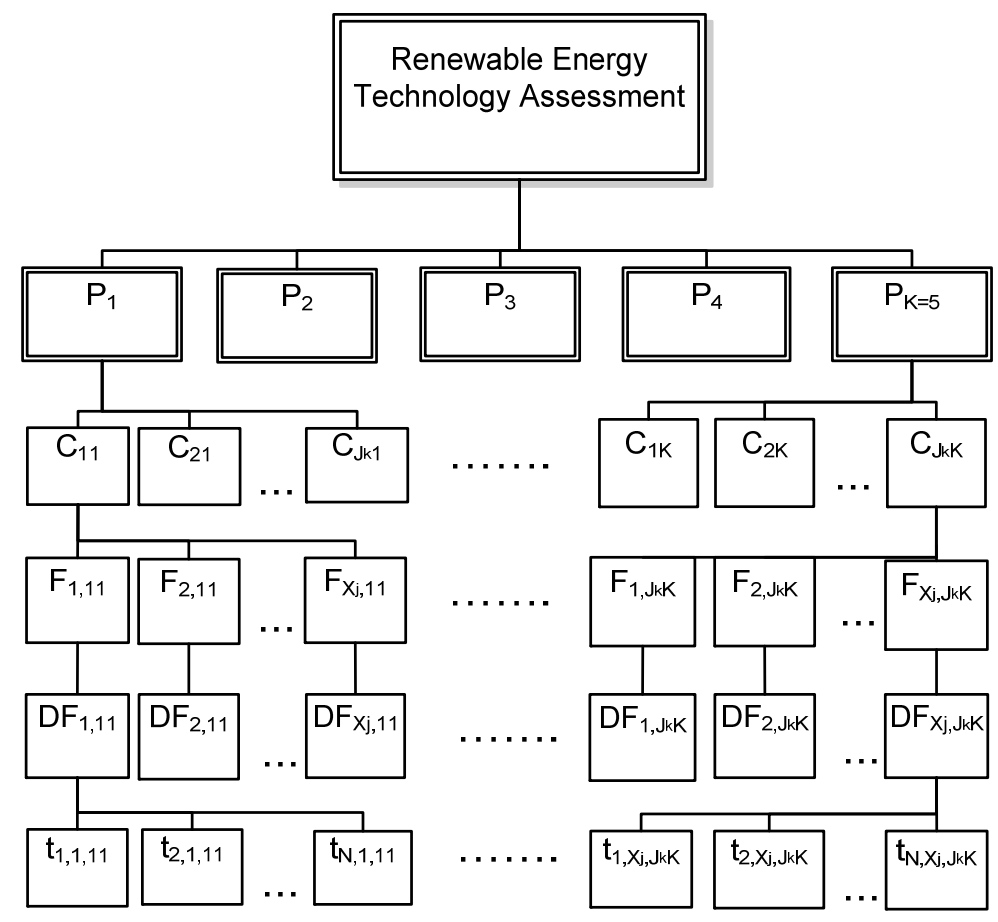

Candidate Technologies $\left(T_{n}\right)$

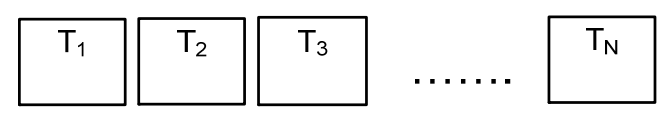


With reference to Figure 13 , the technology value of a technology can be calculated as described in Table 13 below. [It should be noted that the notations for subscripts are modified in the figure due to limitation in Microsoft Visio. Visio cannot display sub-subsubscripts-three levels of subscripts-needed for factor representation.] The calculations are based on earlier work by Nathasit Gerdsri and Dundar Kocaoglu [88]. 
Table 13: Technology Value Calculations

\section{Technology Value Formula}

Descriptions of Variables

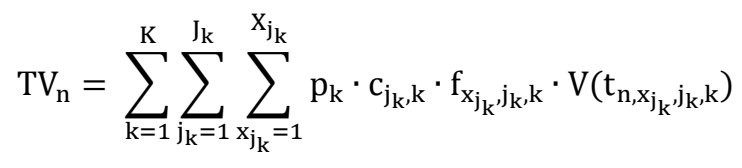

Where

$T V_{n}:$

Technology value of technology $(n)$ as a candidate for fulfilling the mission of determining the best technology. Values range from 0 to 100.

\begin{tabular}{|c|c|}
\hline$p_{k}:$ & $\begin{array}{l}\text { Relative priority of perspective } \\
(k) \text { with respect to the missior }\end{array}$ \\
\hline$c_{j_{k}, k}:$ & $\begin{array}{l}\text { Relative importance of } \\
\text { criterion }\left(j_{k}\right) \text { with respect to } \\
\text { perspective }(k)\end{array}$ \\
\hline$f_{x_{j_{k}, j_{k}, k}}:$ & $\begin{array}{l}\text { Relative importance of factor } \\
\left(x_{j_{k}}\right) \text { with respect to criterion } \\
\left(j_{k}\right)\end{array}$ \\
\hline$V\left(t_{n, x_{j_{k}}, j_{k}, k}\right):$ & $\begin{array}{l}\text { Desirability value of the } \\
\text { performance and physical } \\
\text { characteristics of technology } \\
(n) \text { for factor }\left(x_{j_{k}}\right) \text {, criterion } \\
\left(j_{k}\right) \text {, and perspective }(k) \text {. The } \\
\text { desirability values are along } \\
\text { the desirability function for } \\
\text { that specific technology } \\
\text { characteristic and values rang } \\
\text { from } 0 \text { to } 100 \text {. }\end{array}$ \\
\hline$t_{n, x_{j_{k}}, j_{k}, k}:$ & $\begin{array}{l}\text { Performance and physical } \\
\text { characteristics (metrics) of } \\
\text { technology }(n)\end{array}$ \\
\hline
\end{tabular}
technology $(n)$

For the case where there are no factors for each criterion, the general form of HDM is reduced as shown in Figure 14. 
Mission (M)

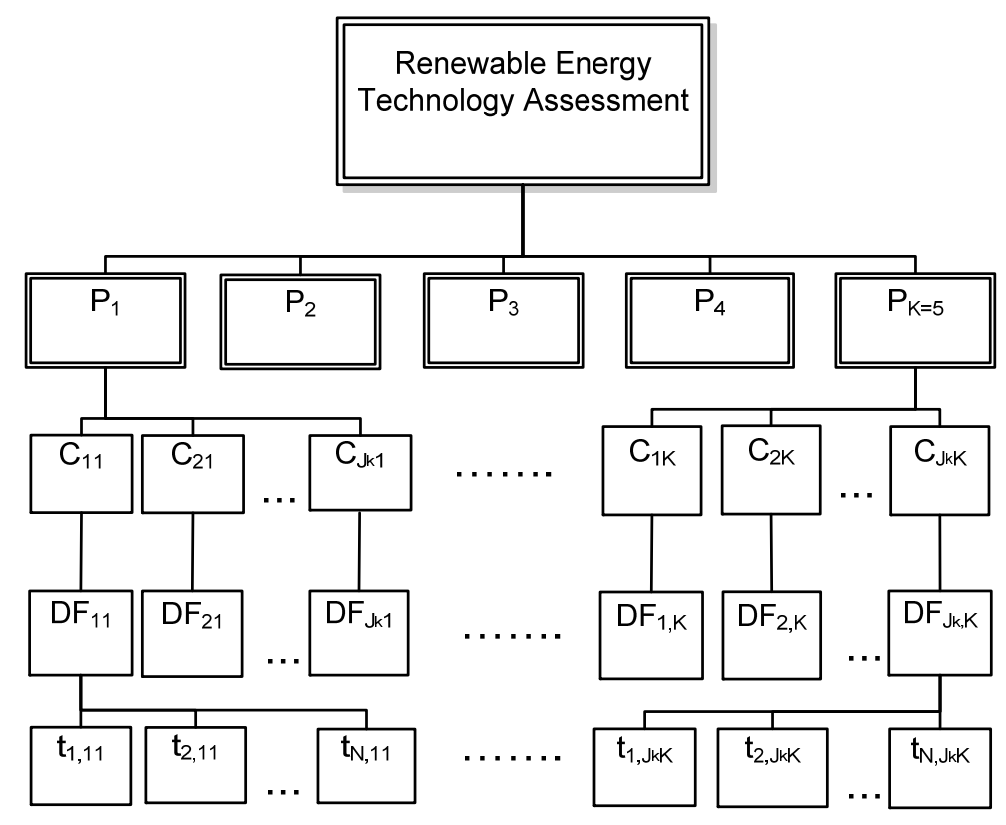

Candidate Technologies $\left(T_{n}\right)$

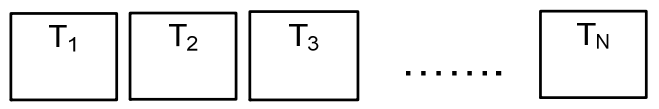

Figure 14: Hierarchical Decision Model for Assessing Technologies with No Factors

The HDM process for assessment of technologies is described in Table 14 below as six measurement or process steps. (Also refer to Figure 13, Figure 14, and Table 13.) 
Table 14: Measurements to Determine Relative Value of Perspectives, Criteria, Factors, and Desirability Functions

\begin{tabular}{|c|c|c|}
\hline Measurements & Description & Constant Sum \\
\hline $\begin{array}{l}\text { Measurement } 1 \text { - } \\
\text { Perspectives }\end{array}$ & $\begin{array}{l}\text { Calculation of } p_{k} \\
\text { Expert comparative judgments are obtained } \\
\text { via a judgment quantification instrument } \\
\text { with a total of } 100 \text { points being allocated for } \\
\text { pairwise comparison. For example, } \\
\text { comparing two perspectives } p_{1} \text { and } p_{2} \text { or } \\
\left(p_{1}: p_{2}\right) \text {, the points allocation may be } 25: 75 \\
\text { (or a ratio scale of } 1: 3) \text {. [The constant sum- } \\
\text { method is applied.] } \\
\text { The group (aggregate) values for the relative } \\
\text { priorities of the perspectives are then } \\
\text { calculated as the mean of the individual } \\
\text { expert values }\end{array}$ & $\sum_{k=1}^{K} p_{k}=1 \quad\left[\right.$ Where $\left.p_{k}>0\right]$ \\
\hline $\begin{array}{l}\text { Measurement } 2 \text { - } \\
\text { Criteria }\end{array}$ & $\begin{array}{l}\text { Calculation of } c_{j_{k}, k} \\
\text { The same approach as Measurement } 1 \text { is } \\
\text { applied for obtaining relative values of } \\
\text { criteria. }\end{array}$ & $\sum_{j_{k}=1}^{J_{k}} c_{j_{k}, k}=1 \quad\left[\right.$ Where $\left.c_{j_{k}, k}>0\right]$ \\
\hline $\begin{array}{l}\text { Measurement } 3 \text { - } \\
\text { Factors }\end{array}$ & $\begin{array}{l}\text { Calculation of } f_{x_{j_{k}}, j_{k}, k} \\
\text { The same approach as Measurement } 1 \text { is } \\
\text { applied for obtaining relative values of } \\
\text { factors. }\end{array}$ & $\begin{array}{l}\sum_{x_{j_{k}}=1}^{x_{j_{k}}} f_{x_{j_{k}, j_{k}, k}}=1 \\
\text { [Where } f_{x_{j_{k}, j_{k}, k}}>0 \text { ] }\end{array}$ \\
\hline $\begin{array}{l}\text { Measurement } 4 \text { - } \\
\text { Desirability } \\
\text { Function }\end{array}$ & $\begin{array}{l}\text { Construction of } D F_{x_{j_{k}}, j_{k}, k} \\
\text { The relative desirability values for each } \\
\text { factor metric can be represented as a } \\
\text { desirability function (or curve) with metric } \\
\text { values on the horizontal axis and the } \\
\text { corresponding desirability value on the } \\
\text { vertical axis. } \\
\text { The desirability functions can be developed } \\
\text { in the following way: } \\
\text { Identifying the limits on the horizontal axis } \\
\text { by determining the best and worst limiting } \\
\text { factor metrics. This provides the range of } \\
\text { values for the metrics. For example, the } \\
\text { factor "PV cell efficiency" will range from } 0 \% \\
\text { to } 100 \% \text {. } \\
\text { For the simple case of where the desirability } \\
\text { values are known to be linearly proportional } \\
\text { to the metrics, two metric values and two }\end{array}$ & \\
\hline
\end{tabular}




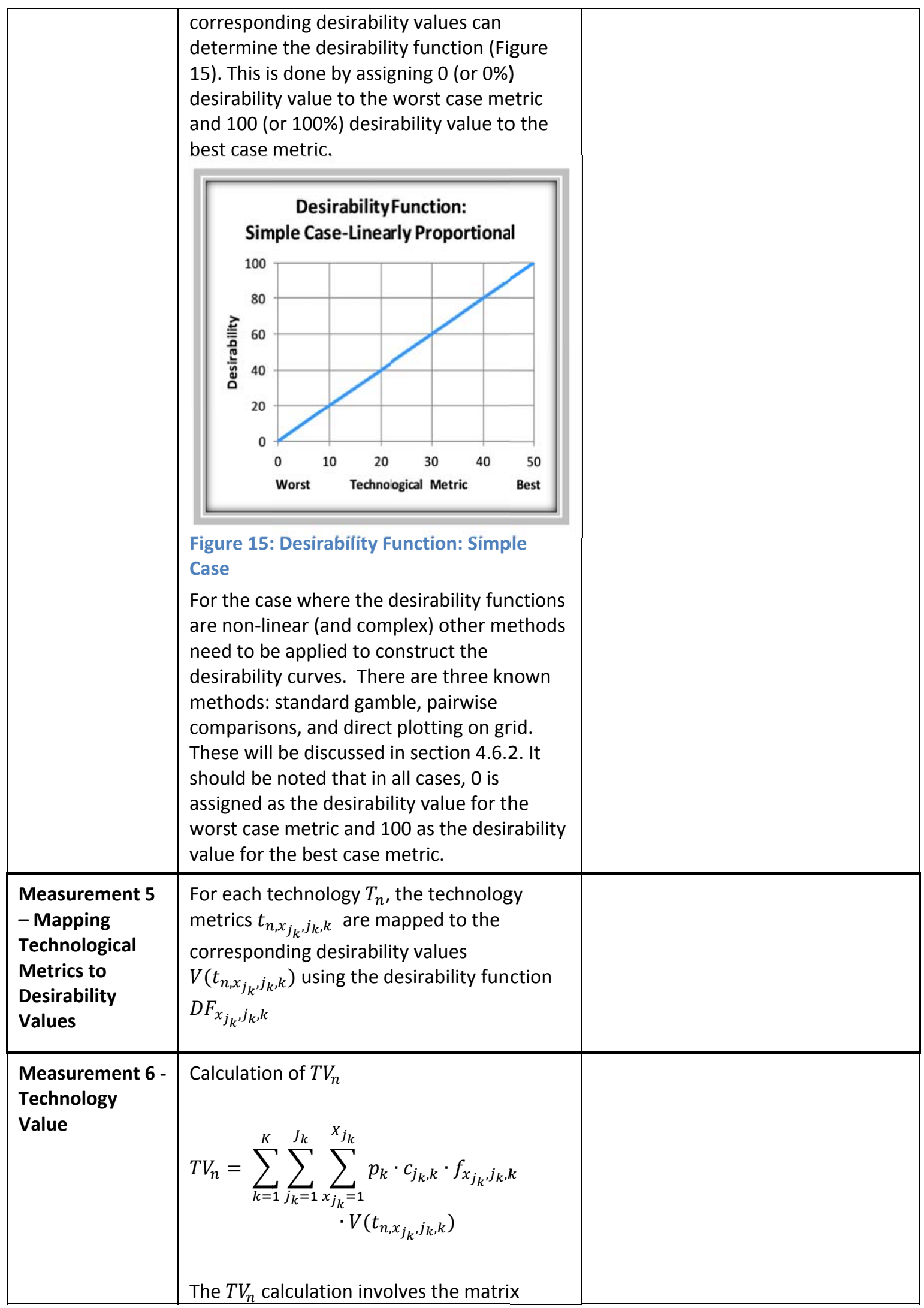




\begin{tabular}{|l|l|l|}
\hline & $\begin{array}{l}\text { computations for relative priorities or } \\
\text { importance of perspectives, criteria, factors, } \\
\text { and desirability values. } \\
\text { The result is the technology value according } \\
\text { to the mission (level one). Considering the } \\
\text { mission, the best or ideal technology would } \\
\text { have a } T V_{n} \text { value of } 100 .\end{array}$ & \\
\hline $\begin{array}{l}\text { Measurement 6 - } \\
\text { Technology } \\
\text { Value - Special } \\
\text { Case With No } \\
\text { Factors }\end{array}$ & $\begin{array}{l}\text { If there are only four levels in HDM in the } \\
\text { case when the criteria have no factors (or } \\
\text { sub-criteria) then } T V_{n} \text { is reduced to: }\end{array}$ & \\
$\qquad V_{n}=\sum_{k=1}^{K} \sum_{j_{k}=1}^{J_{k}} p_{k} \cdot c_{j_{k}, k} \cdot V\left(t_{n, j_{k}, k}\right)$ & \\
& $\begin{array}{l}\text { With the desirability functions defined for } \\
\text { each criterion as: }\end{array}$ & \\
\hline
\end{tabular}

\subsubsection{Developing the Desirability Function}

The desirability function is based on the idea that the quality of a product or process consists of multiple performance measures or quality characteristics and these characteristics need to be within "desired limits" to be acceptable. Furthermore, this approach also identifies the characteristic value(s) that provides the highest desirability - for example, a desirability value of 100 in a range of 0 to 100 [91].

In this research the desirability functions are used to represent the mapping of technological characteristics or performance measures (referred to as "metrics") to a desirability value in the range of 0 to $100-$ with 100 being most desirable and 0 being unacceptable. The desirability function is plotted as a curve for a range of performance metrics. The curve may be linear, non-linear, and even multimodal. In the case of a 
multimodal curve with multiple peaks, more than one metric value may map onto a desirability value of 100 (i.e. highest desirability). The reader is also referred to Table 14, Measurements 4 and 5 for more discussion on developing the desirability function.

For developing a general desirability function one of the following methods can be used:

- Direct plotting on grid

- Pairwise comparisons

- Standard gamble

The simplest method is direct plotting. Pairwise comparisons can be used as an alternate method. The standard gamble method involves probabilities of outcomes and the expert's (or decision makers) risk propensity or profile. The standard gamble method was not considered for this research. All three methods are described in the following sections.

\subsubsection{Direct Plotting on Grid}

This simple method also involves the use of an expert panel [88]. Each expert compares the relative desirability of a technological metric against a hypothetical best value by assigning a value in the range 0 to 100 . This represents their judgment on the relative desirability. The results of expert panel are then considered and the mean values calculated to represent the panel decision. A generic example is shown below 
with the worst to best metric value range of 0 to 100 . This implies that the worst metric value limit is 0 and the best metric value limit is 100 . Only the expert panel's mean values are shown for clarity. This example could be representative of solar PV cell efficiency factor where $0 \%$ efficiency is the worst value of this metric but efficiency above $70 \%$ adds no value to desirability.

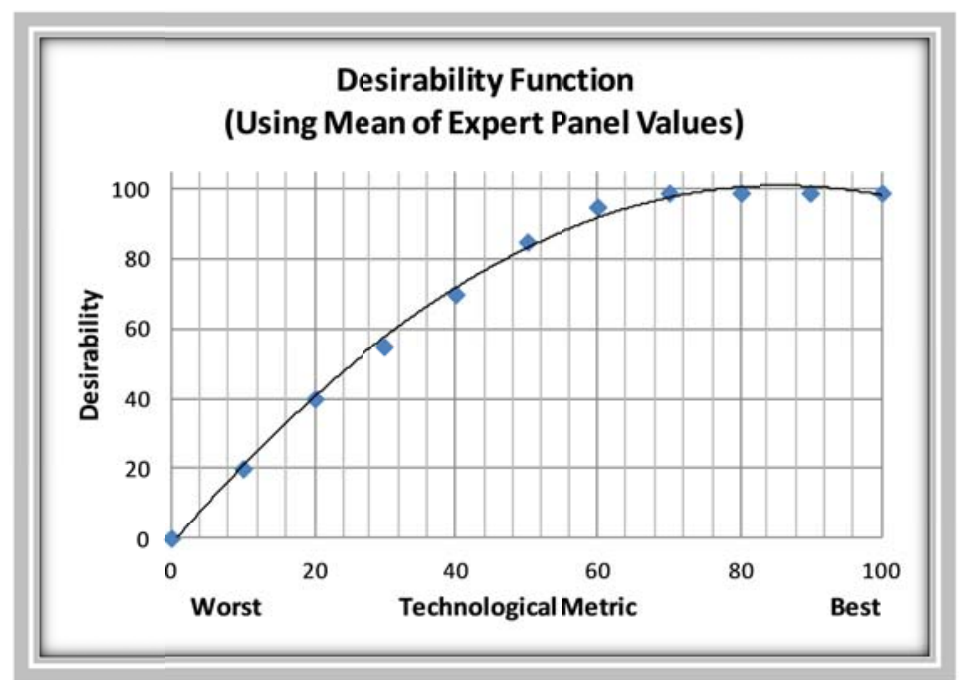

Figure 16: Desirability Function Generic Example Using Direct Plotting Method: Generic Illustration (Showing only the mean values calculated from the judgments of the expert panel)

\subsubsection{Pairwise Comparisons}

Pairwise comparisons method may also be used for developing a desirability function. The pairwise comparison procedure-together with an example-is described below:

- The horizontal axis represents the technological characteristic (metric). Upper and lower limits of acceptable metric values representing the worst and the best should be defined-for example, 20 to 100 . 
- The range of metric values is divided into equal intervals-for example, 20, 40, $60,80,100$.

- Expert judgment is applied comparing two metric values at a time using pairwise comparison-for example, 20:40, 20:60, 20:80, and 20:100). Using constant sum method the results would translate to relative ranking of the metric values -for example, using "metric value (relative ranking)" notation: 20 (0.13), 40(0.16), 60(0.18), 80(0.26), 80(0.26).

- Then ratio scale (with $\times 100$ factor for a desirability function range of 0 to 100 ) is applied in comparison to the highest relative rank value-for example, using 0.26 as the highest value: $20(50), 40(60), 60(70), 80(100), 80(100)$. This example has two "best" metric values, 80 and 100.

The results of the example are shown in Figure 17.

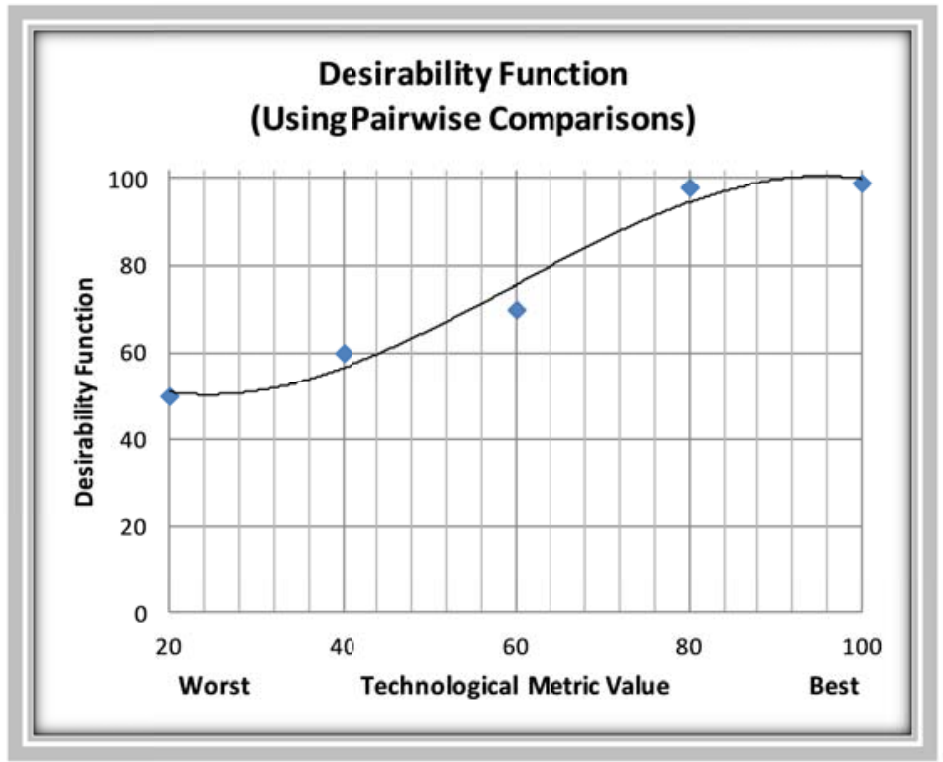

Figure 17: Desirability Function Example Using Pairwise Comparison Method: Generic Illustration 


\subsubsection{Standard Gamble}

A method that is used to develop utility functions is the standard gamble which essentially reflects preferences based on risk propensity. Utility in this case may be defined as, "a measurement of relative liking or preferences on the part of a decision maker [or expert] for particular outcomes" [92]. Utility functions for money are referred to as preference functions. The standard gamble is typically used in financial applications where a decision maker is not indifferent to the amount of money he or she is prepared to win or lose (i.e. gamble). It is also used in risk attitudes in medical or healthcare applications, for example where the patient is prepared to gamble with death for an improved health outcome [93]. In medical usage the standard gamble (also known as the standard reference gamble) is defined as: "a method of diagnostic testing in which a decision maker is faced with a choice between a certain outcome or intermediate value and a gamble involving a better or worse outcome. The outcomes are assigned arbitrary numeric values of 100 [best] and 0 [worst], respectively. All other outcomes can be assigned values relative to the best and worst outcomes". [94]

The following monetary example illustrates the standard gamble and a preference function [92]. (A preference function is similar to a desirability function. The difference is that probabilities and expected values are used to construct the preference function and the concepts of certainty equivalents, standard gamble, and expected preference (or utility) - rather than expected monetary value-are used.) 
A decision maker is faced with two possible choices-Act A and Act B (Refer to the decision tree in Figure 18). If Act $A$ is selected the payoff $V_{0}$ is certain (i.e. probability is 1) and there is no gamble. If Act $B$ is selected, payoff is $V_{1}$ with probability $p$ (probability of higher payoff) or payoff is $V_{2}$ with probability (1-p) [Assume $V_{1}>V_{2}$.] The certain payoff $V_{0}$ is assumed to be in between $V_{1}$ and $V_{2}$ or $V_{1}>V_{0}>V_{2}$. This concept is referred to as the standard gamble.

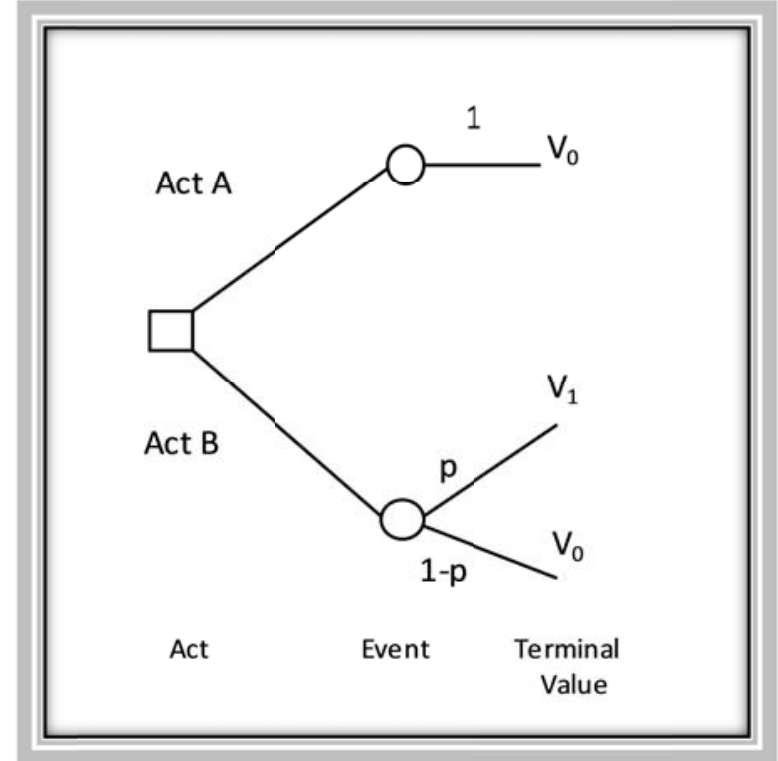

Figure 18: Standard Gamble Example - Reference Gamble

The question is which Act should the decision maker select? Assume $V_{0}=\$ 500, V_{1}=$ $\$ 1000$, and $V_{2}=\$ 0$. The expected value of Act $B\left(E V_{B}\right)$ can be calculated as $(\$ 1000)(p)+(\$ 0)(1-p)$ or $\$ 1000 p$. The result of $A c t A$ is a certain $\$ 500\left(E V_{A}\right)$. At what probability $\mathrm{p}$ would the decision maker be indifferent to Act A or Act B? Equating the 
two Acts results in $p=0.5$. Hence, the certain payoff of Act $A\left(V_{0}\right)$ is equivalent to the gamble of Act $B\left(V_{1}\right)$ if $p=0.5$ and this is called certainty equivalent.

Now, if $p$ is allowed to vary and the decision maker is asked to determine $V_{0}$ at the point of indifference $\left(V_{0 \text {-CertEquiv }}\right)$ between Act $A$ and $A c t B$, two end points are clear. At $\mathrm{p}=1, \mathrm{~V}_{0 \text {-CertEquiv } \mid \mathrm{p}=1}=\$ 1000$, and $\mathrm{p}=0, \mathrm{~V}_{0 \text {-CertEquiv } \mid \mathrm{p}=0}=\$ 0$. Considering other points, for

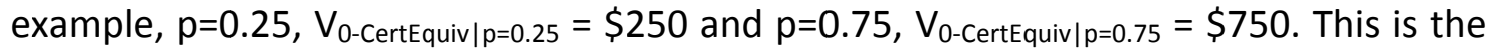
case of a risk neutral individual. Hence a preference function chart indicating the relative preference for money can be developed for individuals with varying risk profiles (risk seekers, risk neutral, or risk avoiders) as shown in Figure 19.

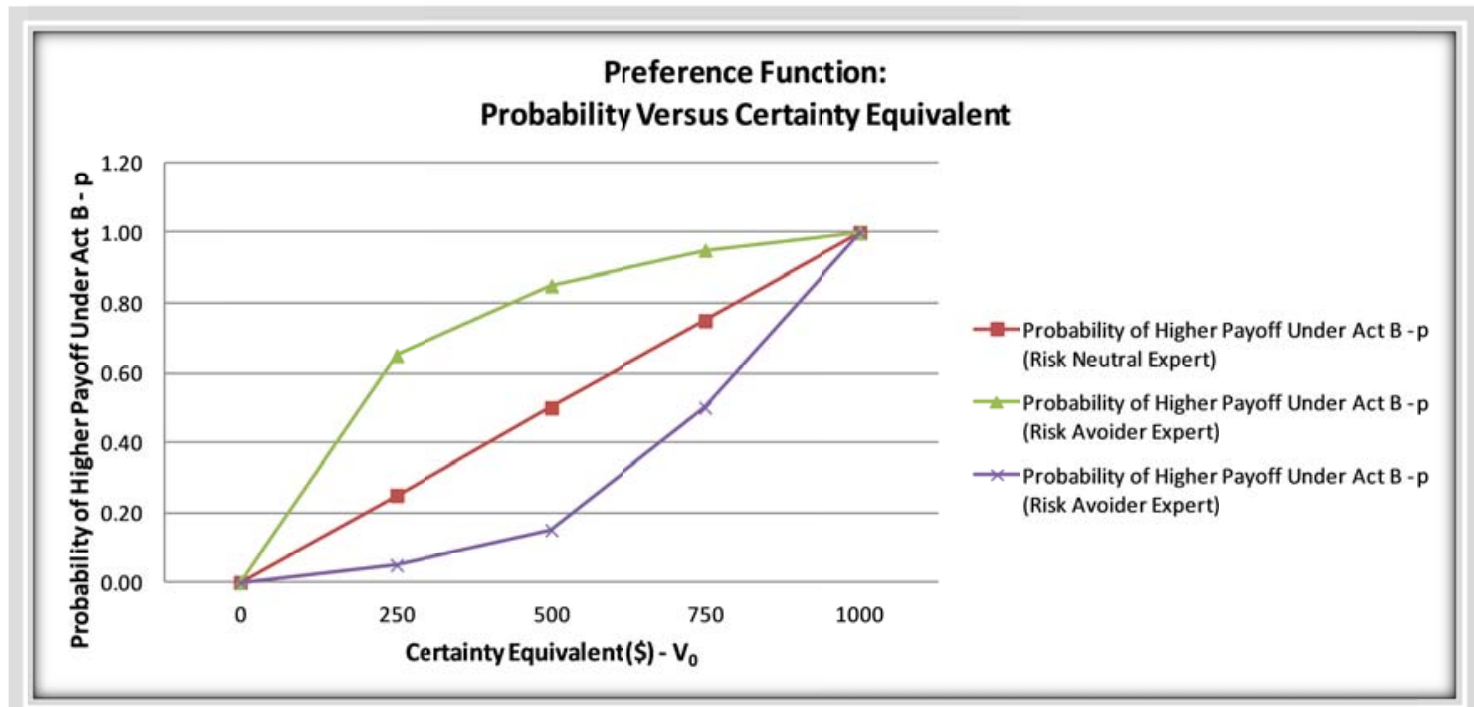

Figure 19: Preference Function Example Using Standard Gamble Method - For a Specific Risk Profile

The steps to develop a preference function are as follows:

- A reference gamble is defined as in Figure 18. 
- The preference function covers the entire range of monetary values with $V_{0}$ (certainty equivalent) varying between $V_{1}$ and $V_{2}$

- Preference is defined in terms of $p$ (probability of $V_{1}$, the higher payoff). Holding everything else constant $V_{0}$ is allowed to vary with $p$. Then matched pairs of $V_{0}$ and $p\left(V_{0}, p\right)$ are determined at point of indifference (the two acts are equally attractive).

- The result is a preference function showing relationship between $V_{0}$ and $p$

\subsubsection{Adding a New Technology}

Using the above approach, a new technology can be added if its technological metrics $\left(t_{n, x_{j_{k}}, j_{k}, k}\right) \quad$ [for $x_{j_{k}}=1$ to $X_{j_{k}}, j_{k}=1$ to $J_{k}, k=1$ to $K$ ] are known (or can be calculated). These metrics are mapped onto the desirability function to produce the desirability values. Then $T V_{n}$ can be calculated according to the equation:

$$
\mathrm{TV}_{\mathrm{n}}=\sum_{\mathrm{k}=1}^{\mathrm{K}} \sum_{\mathrm{j}_{\mathrm{k}}=1}^{\mathrm{J}_{\mathrm{k}}} \sum_{\mathrm{x}_{\mathrm{j}_{\mathrm{k}}}=1}^{\mathrm{x}_{\mathrm{j}_{\mathrm{k}}}} \mathrm{p}_{\mathrm{k}} \cdot \mathrm{c}_{\mathrm{j}_{\mathrm{k}}, \mathrm{k}} \cdot \mathrm{f}_{\mathrm{x}_{\mathrm{j}_{\mathrm{k}}}, \mathrm{j}_{\mathrm{k}}, \mathrm{k}} \cdot \mathrm{V}\left(\mathrm{t}_{\mathrm{n}, \mathrm{x}_{\mathrm{k}}, \mathrm{j}_{\mathrm{k}}, \mathrm{k}}\right)
$$

The "technology value" of 100 is the ideal technology value with respect to the toplevel mission. Hence, the "technology value" score is also representative of the degree that the technology matches the mission (or overall objective). 


\subsection{Data Management}

\subsubsection{Data Collection Process}

The general research process for this type of research includes multiple steps from determining the research problem and stating the research questions to answering the research questions through data collection and validation as shown in Figure 20.

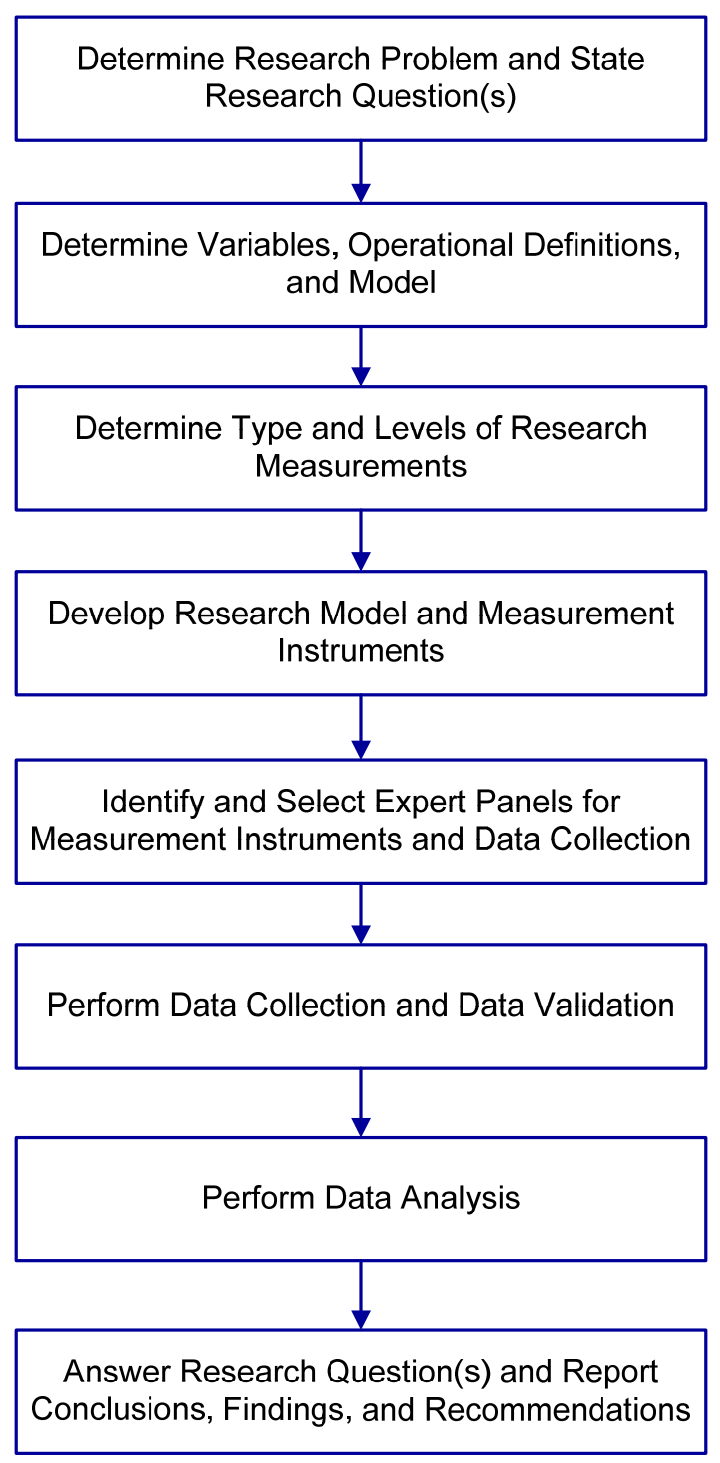

Figure 20: The Research Process 
The data collection process requires subjects (in this case, panels of experts) to provide information and uses instruments to collect data on different variables from these experts. The measurement process provides a value (numeric or category) to variables and systematically measures variables using specific steps.

\subsubsection{Data Validation}

An instrument is a tool used to measure expert judgment. The instruments should be valid, reliable, and practical. Validity of instruments refers to the extent the instrument measures what it is intended to precisely measure [95]. A test with high validity has results closely linked to the intended focus of the test. A test with low or poor validity does not measure the content and criteria that it was designed for. Reliability refers to the extent to which the measurement results are repeatable. Practicability is the ease with which it is easy to construct, administer, use, score, interpret, and modify the instrument. An acceptable research design aims to optimize research validity in three types of validity: content validity, construct validity, and criterion-related validity [96]. 
Table 15: Research and Data Validation

\begin{tabular}{|c|c|c|c|}
\hline $\begin{array}{l}\text { Research } \\
\text { Validation }\end{array}$ & Test Description [96] & Test Methods & When Applied \\
\hline Content Validity & $\begin{array}{l}\text { This is the degree to which a } \\
\text { measure covers the range of } \\
\text { meanings within the concept. }\end{array}$ & $\begin{array}{l}\text { Pilot testing, evaluation } \\
\text { by experts, and literature } \\
\text { review }\end{array}$ & $\begin{array}{l}\text { During research } \\
\text { instrument and } \\
\text { model preparation }\end{array}$ \\
\hline $\begin{array}{l}\text { Construct } \\
\text { Validity }\end{array}$ & $\begin{array}{l}\text { This refers to the way a } \\
\text { measure relates to other } \\
\text { variables within a system of } \\
\text { theoretical relationships. It } \\
\text { implies that the constructs- } \\
\text { such as concepts, ideas, and } \\
\text { notions-are in accordance to } \\
\text { the state-of-the-art in the } \\
\text { field. Furthermore, it implies } \\
\text { that the operationalized } \\
\text { attributes are mutually } \\
\text { exclusive and exhaustive. }\end{array}$ & $\begin{array}{l}\text { Pilot testing, evaluation } \\
\text { by experts, and literature } \\
\text { review }\end{array}$ & $\begin{array}{l}\text { After the } \\
\text { development of the } \\
\text { model }\end{array}$ \\
\hline $\begin{array}{l}\text { Criterion-Related } \\
\text { Validity }\end{array}$ & $\begin{array}{l}\text { This is also known as } \\
\text { predictive validity or } \\
\text { instrumental validity. It } \\
\text { measures the degree to } \\
\text { which the predictor is } \\
\text { adequate in capturing the } \\
\text { relevant aspects of the } \\
\text { criterion. }\end{array}$ & $\begin{array}{l}\text { Pilot testing, use of expert } \\
\text { judgment, and literature } \\
\text { review }\end{array}$ & $\begin{array}{l}\text { After the results are } \\
\text { compiled }\end{array}$ \\
\hline Reliability & $\begin{array}{l}\text { This is the degree to which } \\
\text { the measure is consistent and } \\
\text { repeatable. }\end{array}$ & $\begin{array}{l}\text { Statistical and built-in } \\
\text { consistency analysis }\end{array}$ & $\begin{array}{l}\text { After the results are } \\
\text { compiled }\end{array}$ \\
\hline Practicability & $\begin{array}{l}\text { This is the ease with which } \\
\text { models and measurement } \\
\text { instruments can be } \\
\text { implemented. }\end{array}$ & $\begin{array}{l}\text { Pilot testing and checking } \\
\text { for inherent practicability }\end{array}$ & During pilot testing \\
\hline
\end{tabular}




\section{CONTRIBUTION TO THE BODY OF KNOWLEDGE}

The intellectual merit of this research is the development of a decision making model that will enable a comprehensive assessment of photovoltaic technologies to assist policy makers, technology suppliers, energy utilities, universities/research institutes/national labs to make better decisions on technology evaluation and commercialization. The model will provide knowledge for decision makers with respect to five perspectives: social, technical, economic, environmental, and political (STEEP).

For each type of decision making body the model will provide a different type of value. This is illustrated below with respect to the following worldviews:

- Policy makers - identify relative importance of national priorities with respect to the technologies

- Technology suppliers - provide a basis for identifying weaknesses in the technology and where development efforts will be effective

- Energy utilities - identify which technologies are best suited for large scale system deployments suitable for utilities

- Universities, research institutes, and national laboratories - identify areas of research focus

The research is built on the foundation laid by Harold A. Linstone on decision making and evaluating technologies using multiple perspectives (TOP - technology, 
organizational, and personal perspectives) [11]. The fundamental concepts can be expanded to be applicable for renewable energy technologies, systems, and processes using STEEP. Applying STEEP perspectives is part of ongoing research at the Research Institute for Sustainable Energy (RISE), Department of Engineering and Technology Management (ETM), Portland State University, Oregon. The model for decision making is based on HDM (also known as "MOGSA" - mission, objectives, goals, strategies, and actions). The measurement of judgment quantification process in HDM was developed by Dundar Kocaoglu [62]. The combination of the HDM element ranking and the desirability function value will provide an overall "technology value". This technology value is based on the research by Nathasit Gerdsri and Dundar Kocaoglu [88].

This research does not develop new theory but it is an application of HDM with STEEP perspectives related to solar photovoltaics. 


\section{INITIAL MODELING AND TEST CASE}

The literature review revealed gaps in the comprehensive assessment of energy (and in particular solar) technologies and that filling these gaps may improve the overall assessment with respect to the five STEEP perspectives.

By way of a literature review [15], experiential knowledge, and discussion with energy experts the author was able to group the factors into categories or criteria and hence build sets of criteria for each perspective. (This may be considered as a "bottom-up" approach.) This identification of factors and development of criteria from factors is, in fact, an ongoing process due to the changing landscape of renewable energy. Policy makers-at international, national, regional, and local levels, utilities, and manufacturers will likely need to assess and compare technology and energy options on an ongoing basis. Hence, the author believes that there is value in building and updating extensive sets of criteria to be considered for technology assessments. This is especially true for social, environmental, and political perspectives. As a consequence of this literature review it was possible to compile a large number of criteria and factors for each perspective.

\subsection{Modeling: Criteria Classification and Selection}

Based on information found in the literature or expert interviews on multi-criteria decision analysis MCDA-based applications that related to energy planning, issues, 
policies, systems, and resources, the high level criteria were assigned, defined, or developed to represent or be descriptive of a group of factors. The major criteria or constraints for each perspective are listed in Table 16 and defined later in this section. Each criterion is composed of multiple sub-criteria or factors. The criteria and related factors are explained in this section. These are also listed in Appendix B and are developed mainly from a literature review [15]. The social and political perspectives together with their criteria and factors are described in more detail in a working paper [97]. These criteria and factors form an initial baseline in the formulation of the final HDM.

Table 16: Multiple Criteria for Each Steep Perspective (Based on [15] And Expert Opinions)

\begin{tabular}{|c|c|c|c|c|}
\hline Social & Technical & Economic & Environmental & Political \\
\hline $\begin{array}{l}\text { S1: Public } \\
\text { Perception }\end{array}$ & T1: Efficiency & E1: Product Costs & $\begin{array}{l}\text { N1: Pollution/ } \\
\text { Negative Impact }\end{array}$ & P1: Policies \\
\hline S2: Employment & $\begin{array}{l}\text { T2: Technology } \\
\text { Maturity }\end{array}$ & $\begin{array}{l}\text { E2: LCOE } \\
\text { (Electricity } \\
\text { Generation Costs) }\end{array}$ & $\begin{array}{l}\text { N2: } \\
\text { Environmental } \\
\text { Benefits/ Positive } \\
\text { Impact }\end{array}$ & $\begin{array}{l}\text { P2: Regulation/ } \\
\text { Deregulation of } \\
\text { Power Markets }\end{array}$ \\
\hline $\begin{array}{l}\text { S3: Health \& } \\
\text { Safety }\end{array}$ & $\begin{array}{l}\text { T3: Production / } \\
\text { Operations }\end{array}$ & $\begin{array}{l}\text { E3: Financial } \\
\text { Analysis }\end{array}$ & $\begin{array}{l}\text { N3: End-of-Life / } \\
\text { Disposal }\end{array}$ & $\begin{array}{l}\text { P3: Public / } \\
\text { Government R\&D } \\
\text { Framework }\end{array}$ \\
\hline \multirow[t]{5}{*}{$\begin{array}{l}\text { S4: Local } \\
\text { Infrastructure } \\
\text { Development }\end{array}$} & $\begin{array}{l}\text { T4: } \\
\text { Resources/Materi } \\
\text { als Required }\end{array}$ & $\begin{array}{l}\text { E4: Cost } \\
\text { Mitigation }\end{array}$ & $\begin{array}{l}\text { N4: Consumption } \\
\text { of Resources }\end{array}$ & $\begin{array}{l}\text { P4: Codes / } \\
\text { Standards - } \\
\text { Compliance }\end{array}$ \\
\hline & T5: Deployment & $\begin{array}{l}\text { E5: Market } \\
\text { Adoption }\end{array}$ & & $\begin{array}{l}\text { P5: Perception / } \\
\text { Position of } \\
\text { Utilities }\end{array}$ \\
\hline & $\begin{array}{l}\text { T6: Maintenance } \\
\text { /Warranty }\end{array}$ & $\begin{array}{l}\text { E6: Positive } \\
\text { Impact on Local } \\
\text { Economy }\end{array}$ & & P6: Security \\
\hline & $\begin{array}{l}\text { T7: Codes / } \\
\text { Standards - } \\
\text { Development }\end{array}$ & & & \\
\hline & $\begin{array}{l}\text { T8: Technology } \\
\text { Roadmap }\end{array}$ & & & \\
\hline
\end{tabular}




\section{Social Perspective}

\section{S1: Public Perception}

The social phenomenon known as public perception may be viewed as a virtual truth or aspect of the truth that is shaped by popular opinion, media coverage, impact on social norms or livelihood, or reputation. It may consist of such factors as aesthetics, impact on lifestyle, social benefits, and social acceptance.

\section{S2: Employment}

Essentially, employment is a discussion about jobs. It is related to such factors as job creation, availability of workforce, and poverty alleviation.

\section{S3: Health and Safety}

Health and Safety is the protection of safety, health, and welfare of the individuals, society, and the workplace by governments and society. It includes public safety, work safety, prevention of long-term hazardous health effects, and is an investment in the long-term health of society. 


\section{S4: Local Infrastructure Development}

Infrastructure development is a typically a long-term benefit to the locality and region. It consists of infrastructure improvements, promotion of related industry, and empowers the region to improve productivity and quality of life.

\section{Technical Perspective}

\section{T1: Efficiency}

In this context efficiency is an indicator of the amount of useful energy from a renewable energy source or the output productivity in the production of the source. It has multiple definitions and considerations depending on the context. It can include PV module energy efficiency, PV cell energy efficiency, exergy efficiency, inherent system efficiency, thermal efficiency, PV system yield, performance ratio, and energy density.

\section{T2: Technology Maturity}

A technology is considered mature if it has been in use for a long time and many of the associated problems and defects have been corrected. Technology maturity refers to the stage of the technology and is associated with trends and its persistence ability. It includes factors such as: density and maturity of patents, flexibility, scalability, modularity, and obsolescence resistance. 


\section{T3: Production/Operations}

In this context "production" refers to manufacturing of renewable energy sources and "operations" refers to manufacturing operations. This can include: production capacity, production process complexity, ability to leverage well-known processes, production waste management, line breakage, and production maturity.

\section{T4: Resources/Materials Required}

Availability and management of raw materials in the manufacturing process are important for the evaluation of renewable energy sources. Factors key for this criterion include availability of resources, access to resources, avoiding the use of rare metals, avoiding hazardous materials, and chemicals and gases used.

\section{T5: Deployment}

Deployment of the renewable energy source has many forms, considerations, and components. These factors may include: large-scale installations, field performance, service availability, effect of power purchase agreements (PPAs), impact on meeting important national and international energy targets, suitability for installations in buildings, auxiliary storage, transmission, and distribution.

\section{T6: Maintenance/Warranty}

Maintenance and warranty periods are closely aligned with installation and deployment. Important factors in this criterion are low maintenance, long lifetime, 
annual power production degradation warranty, and built-in management of environmental elements such as dust, erosion, and debris.

\section{T7: Codes/Standards - Development}

It is an accepted fact that most renewable energy deployments must be compliant with local, regional, national and/or international standards to some extent. For the United States such standards include the United States Code, building safety standards, and environmental safety standards

\section{T8: Technology Roadmap (2010-2030)}

Besides the current state of the renewable energy technology, its trajectory or roadmap must also be assessed to gain a fuller understanding of the technology direction for the next few decades. This criterion should at least contain the following factors: PV cell and module roadmap, PV technology patents and publication trends, inverter and balance-of-system trends.

\section{Economic Perspective}

\section{E1: Product Costs}

Clearly the product cost is important for the sale of renewable energy technologies since it directly translates to product pricing. Product cost can be broken down into factors such as the amortized capital costs, amortized startup costs, cost of raw 
materials, direct production costs, sales and marketing costs, R\&D and engineering costs, general and administrative costs, facilities and rent costs, warranty and maintenance costs, installation costs, and auxiliary installation equipment (called "balance-of-system") costs. In today's environment disposal, recycling, and end-of-life disposal costs are also becoming more important factors.

\section{E2: Electricity Generation Costs - LCOE (Levelized Cost of Energy)}

The total cost of electricity generation over the life of the renewable energy source assists in deciding the equivalent operating cost per kWhr. It has traditionally been calculated as standardized or levelized cost of energy over the lifecycle of the product or energy source. But this formula did not typically include the end-of-life disposal costs. For a comprehensive assessment of technology another calculation should be made and included as a factor to reflect the true cost.

\section{E3: Financial Analysis}

In this context financial analysis has been defined as the analysis related to the viability of energy investments and benefits derived and include factors such as cost/benefit analysis for public projects, return on investment (ROI), projected savings to power utilities, energy portfolio costs to utilities (to supply power vis-à-vis renewable energy sources), and a roadmap of costs over the next two decade. This criterion provides a long-term landscape for investment purposes and enables experts or decision makers to compare to other important economic criteria. 


\section{E4: Cost Mitigation}

One aspect or criterion of the economic perspective is cost mitigation or how a renewable energy technology or source can help to alleviate overall costs. This criterion is not commonly considered since the general perception is that renewable energy is provided at a higher economic cost. However, there are multiple factors that positively affect cost mitigation and include: independence from economies of scale (implying that building a higher capacity power plant from a renewable energy source will increase exponentially with size due to complexity of larger systems), energy supply chain advantage (since fossil fuels require costly distribution and the supply chain is extensive), reduction in government administrative costs (involving imported fuels), reduction in military logistics costs (involving energy costs and fuel transportation costs), and better use of hard currency (for developing countries that need to use hard currencies for fuel imports).

\section{E5: Market Adoption}

The criterion of market adoption plays a role in technology diffusion and maturity and indicates economic acceptance. For market adoption to occur and grow certain factors play a role such as existing market maturity (and acceptance), product or technology maturity, supply chain or distribution maturity, compliance with the national codes (for example, the United States Code), customer willingness to pay (the higher cost of electricity), and economic multiplier effect (through renewable energy infrastructure). 
The multiplier-effect theory was first introduced by economist John Maynard Keynes in 1936. He explained that governments can stimulate economic growth in the private sector through interest rates, taxation and public works. Public works typically involve infrastructure investments that initiate a cascade of events that result in increased economic activity. This cascading effect is indirect and sometimes difficult to calculate upfront, however, the long-term gains become obvious after the fact.

\section{E6: Positive Impact on Local Economy}

Local economies can be impacted through the deployment of renewable energy technologies. Besides the social quality-of-life gains the economic gain may include a mix of factors related to higher wage jobs, new job creation, creating an insourcing trend (and direct opposition to outsourcing), and creation or expansion of economic clusters. Michael E. Porter defined economic clusters as a local concentration of specialized companies and institutions that increase productivity. Cluster development initiatives are an important agenda for many governments as they are seen to improve economic activity. For example, the installation of a local PV manufacturing or system integration plant can be at the heart of a cluster of other related companies and activities that feed-off of the PV product sales and installations. In addition, local universities may increase R\&D activity to support the PV plant. 


\section{Environmental Perspective}

\section{N1: Pollution or Negative Impact}

From an environmental perspective pollution is an important criteria to use for the assessment of an energy technology. The factors that make up this criterion and implying different types of pollution-during the production or deployment phase of the technology-may include: greenhouse gases (GHG), smoke or dust particles, vapor, glare (visual pollution), water, soil, noise, solid waste, water resources (used in production), stratospheric ozone, natural habitat, water temperature change, wind pattern change, forest and ecosystem, ecological footprints (e.g. crops, woods, and marshes), and accidental release of chemicals.

\section{N2: Environmental Benefits or Positive Impact}

There can be a positive impact on the environment due to renewable energy. The factor that make up this positive may include: better land utilization, climate change mitigation, environmental sustainability, low land (real estate) requirements, energy conservation improvement, better consumption of natural resources, reduced fossil fuel imports (or dependence), and better use of rooftops (for PV and wind energy).

\section{N3: Disposal and End-of-Life}

An environmental criterion that is gaining importance is the advanced planning for waste and end-of-life disposal (or dismantling) of renewable energy sources. Factors 
to be considered for this are related to biodegradability, ease in recycling, proper disposal of chemicals and gases used in production or deployment. Another factor may also include leveraging waste disposal management knowhow from existing mature production processes (such as from semiconductor manufacturing).

\section{N4: Consumption of Resources}

Considering that most natural resources are finite, their use especially during manufacturing needs to be part of the technology assessment process. There are three main factors: land, water, and raw materials.

\section{Political Perspective}

\section{P1: Policies}

Renewable energy policies are typically at national or local levels and can mark the success or failure of a renewable energy source. Policy factors include: security, support for renewable energy and/or energy efficiency (such as Feed-in Tariffs (FITs) and Renewable Portfolio Standards (RPSs), national energy independence (from fossil fuels), financing option with government backing, local sourcing, stipulated five-year or ten-year plans for renewable energy or energy efficiency, workforce training on new energy sources, and integration-with/or replacement-of existing power plants. 


\section{P2: Regulation/Deregulation of Power Markets}

The power markets can be managed in many different ways through the political process. Regulation can include factors such as RPS, FIT, net-metering (with the meter reading energy received and supplied from the consumer), incentives, energy price controls through rate structures (and this is a generalized form of FIT), subsidies (such as tax credits, tax exemptions, etc.), carbon tax, cap and trade, and promotion of centralized or decentralized power.

\section{P4: Public/Government R\&D Framework}

Government-funded research can provide a positive impetus to technology development and deployment. This criterion consists of mainly three aspects or factors: support by government national laboratories, increased technology transfer activity to the private sector, and the execution of a strategic technology plan or roadmap.

\section{P5: Codes/Standards - Compliance}

This criterion has the same compliance factors as detailed under the technical perspective and includes: the United States Code (for the United States), national and international standards, and building and environmental safety standards. However, under the political perspective these factors imply that the policies enact the standards and enforce them. 


\section{P6: Perception/Position of Utilities}

The utilities are both commercial and political entities since they are regulated and also have political lobbying clout. In fact the fossil fuel lobbies (also known by some as the "dirty fuel lobbies") are some of the most powerful lobbies in the United States. Their willingness to engage in the deployment of a particular renewable technology is an aspect that should not be ignored. Utilities will not be willing to adopt an energy source that is not aligned with their existing political and management structures. Hence factors for this criterion are: conformance to existing political, legal, and management structures and the position of their political lobbies.

\section{P7: Security}

Security is the responsibility of the government and is public policy issue. Security consists of both energy supply stability and energy price stability. (These are the two factors that comprise the security criterion.) Even if governments cannot control the supply (especially in the case of fossil fuels) they may need to control the price through subsidies because history has proven that energy price escalation can lead to civil unrest.

\subsection{Test Case}

An initial test case was carried out to test the model (framework), judgment quantification instrument (or survey), and the level of validation of the results. 
An initial panel consisting of five experts and four pseudo-experts with a technology supplier were selected and had the following background and experience:

1) Expert 1: 20+ years of experience in global business development, production, planning, and marketing of solar PV related products

2) Expert 2: 20+ years of experience in production and general management of PV and flat panel displays (both technologies use similar manufacturing facilities and methods)

3) Expert 3: 40+ years of experience in executive management and R\&D in solar $\mathrm{PV}$, consumer electronics, and emerging technologies

4) Expert 4: 25+ years of experience in global business development and strategic planning with 5 years in PV strategic planning

5) Expert 5: 10+ years of experience in electronics industry and several years of experience in energy industry with a focus on energy technology planning

6) Four graduate students in Engineering and Technology Management department at Portland State University, Oregon who had gained experience in renewable energy technologies via internships, courses, and research

After the panel selection, the judgment quantification instrument was crafted, reviewed by the expert panel, and revised based on feedback. The survey was then conducted and the initial results were analyzed. (The survey was conducted only once 
since the results were within acceptable "consistency" ranges. For the purposes of the test case a rule of thumb of an inconsistency less than 0.1 was considered acceptable.

\subsubsection{Judgment Quantification Instrument for Expert Panel}

The questionnaire with pairwise comparisons was developed for the judgment quantification instrument and was based on the initial decision model. Sample pages from the questionnaire are displayed in Figure 21 . The complete instrument is in Appendix A.

The judgment quantification instrument contains 80 pairwise comparisons for the 5 survey questions. It took 15 to 30 minutes for each respondent to complete the survey. Even though the expert panel members did not have expertise in all the survey areas each one was requested to complete the entire survey. Hence the level of confidence in completing the survey was mixed, ranging from Very Confident to Unconfident. However, the results were useable because the inconsistency measure was less than or close to 0.1 . 


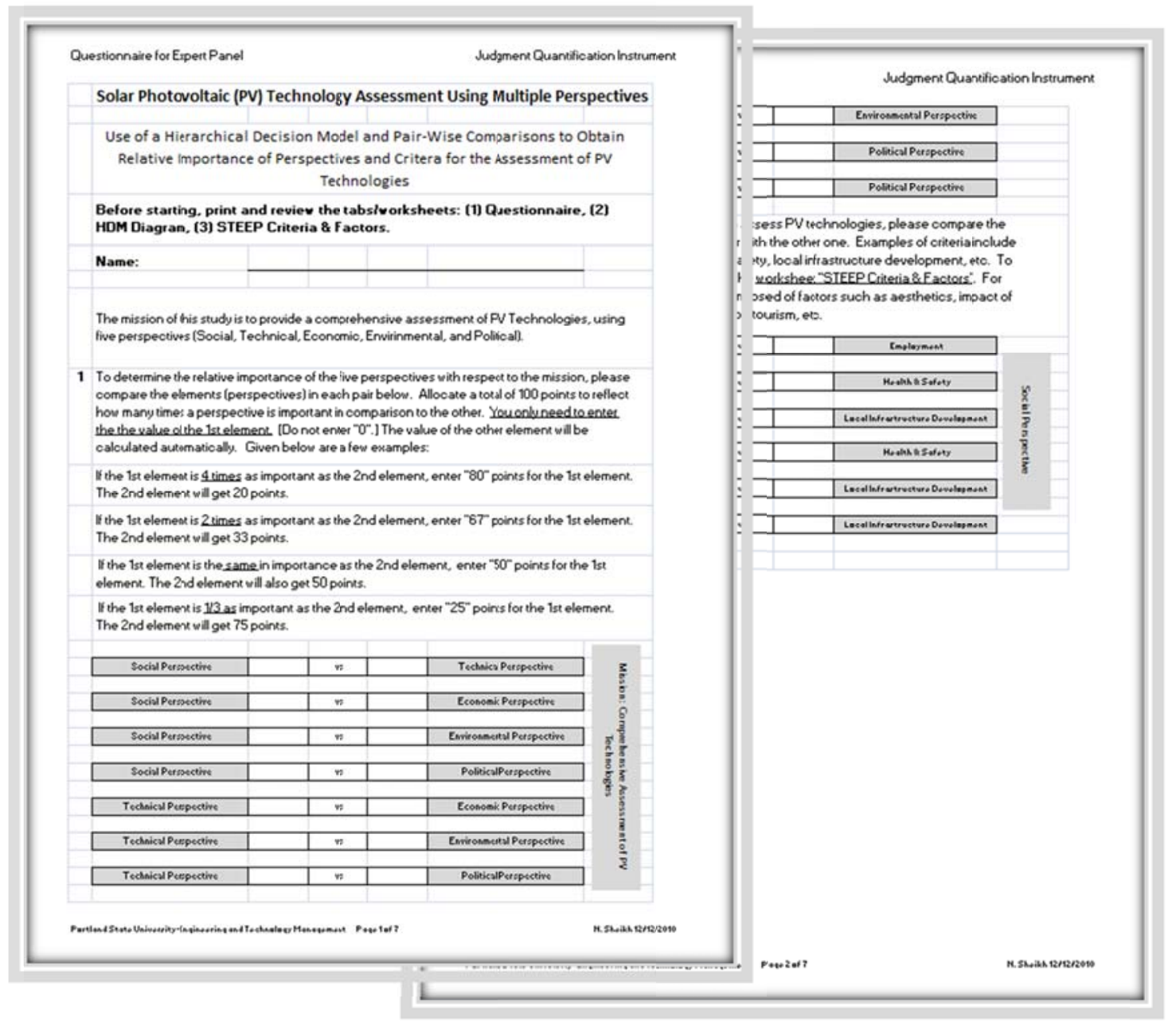

Figure 21: Sample Judgment Quantification Instrument Pages

\subsubsection{Results and Analysis}

The initial composite results for eight "technology supplier/developer worldview experts" are shown in Figure 22, Figure 23, Figure 24, Figure 25, Figure 26, and Figure 27. The initial results for this group indicated that all the multiple perspectives were important from an overall assessment point of view. The importance of the perspectives to the mission is relatively balanced ranging from relative values of 0.19 to 0.22 . [The total is 1.00 for all five perspectives.] Evaluating and ranking the criteria 
for each perspective showed a certain level of variation, however, again, no one or group of criteria was dominant or stood out. Table 17 lists the highest and lowest criterion/criteria for each perspective.

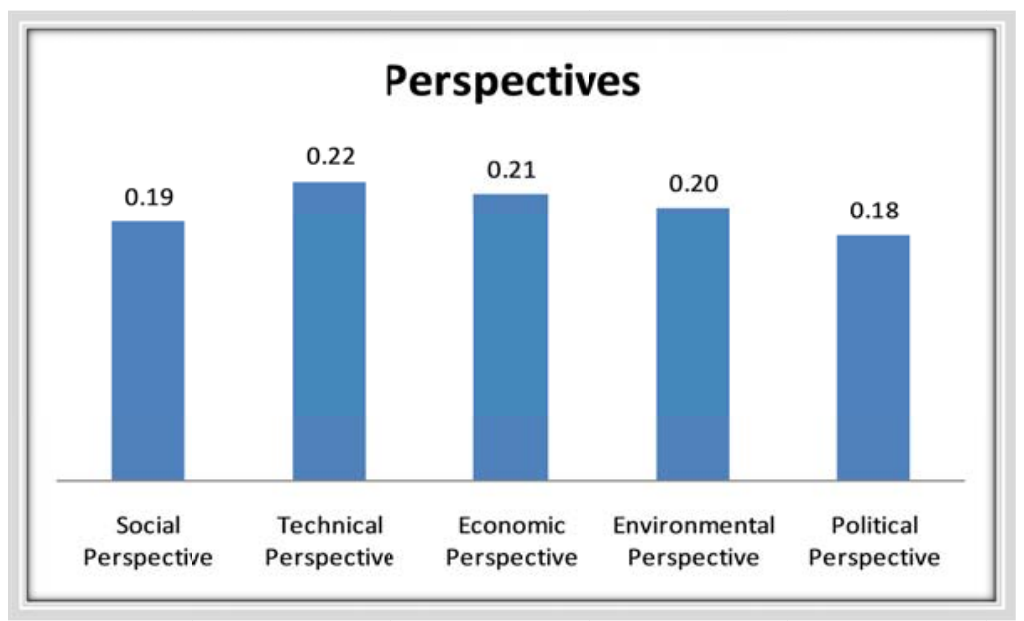

Figure 22: STEEP Perspectives

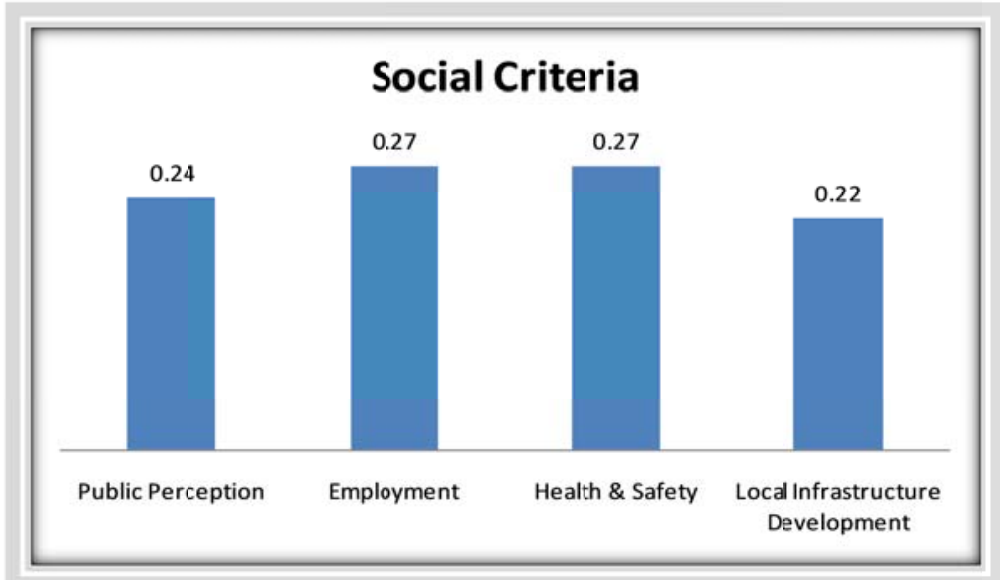

Figure 23: Social Perspective 


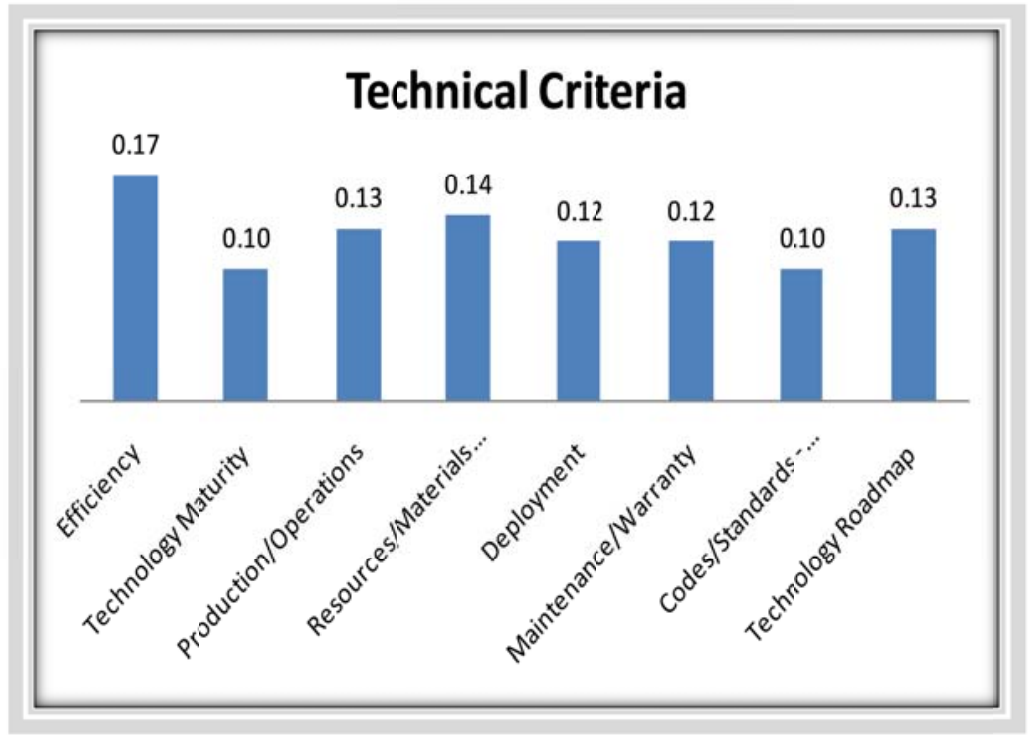

Figure 24: Technical Perspective

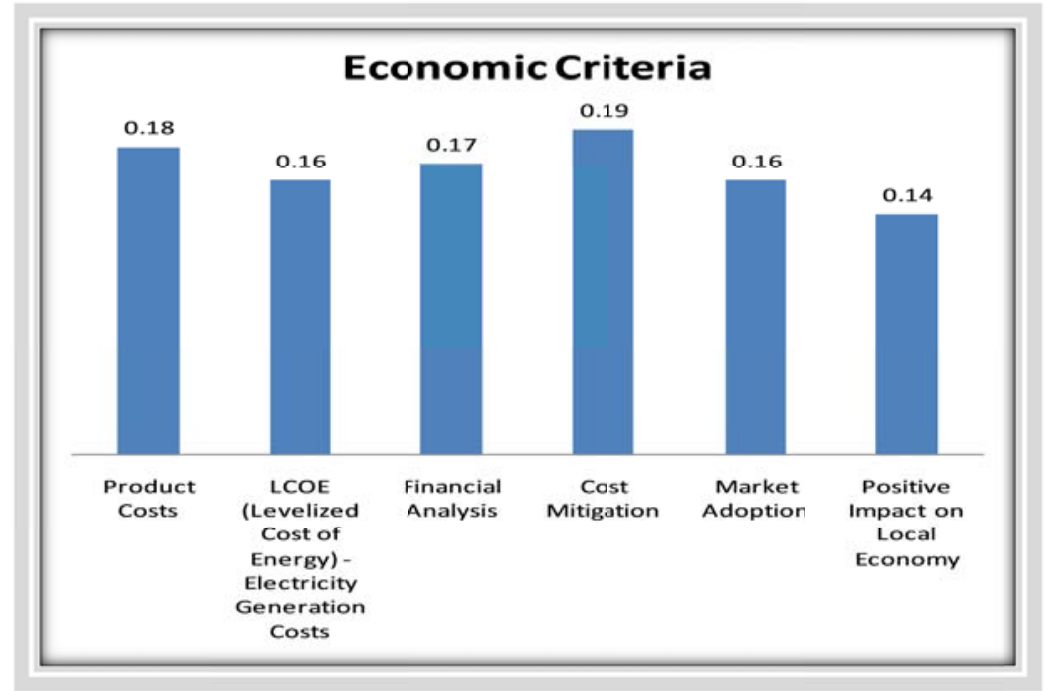

Figure 25: Economic Perspective 


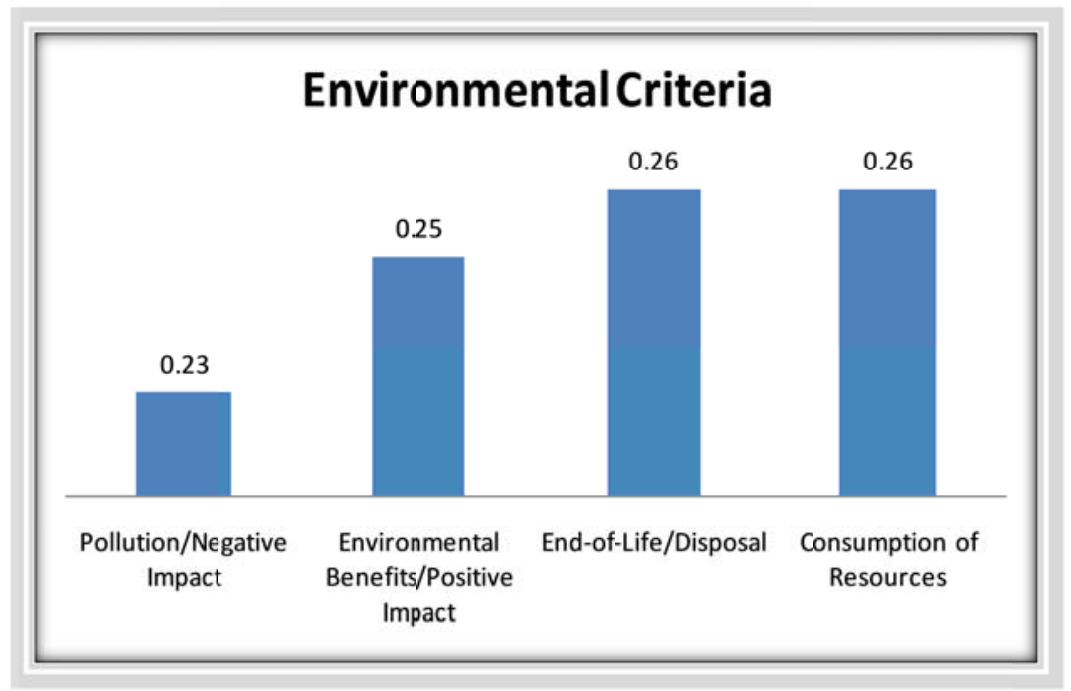

Figure 26: Environmental Perspective

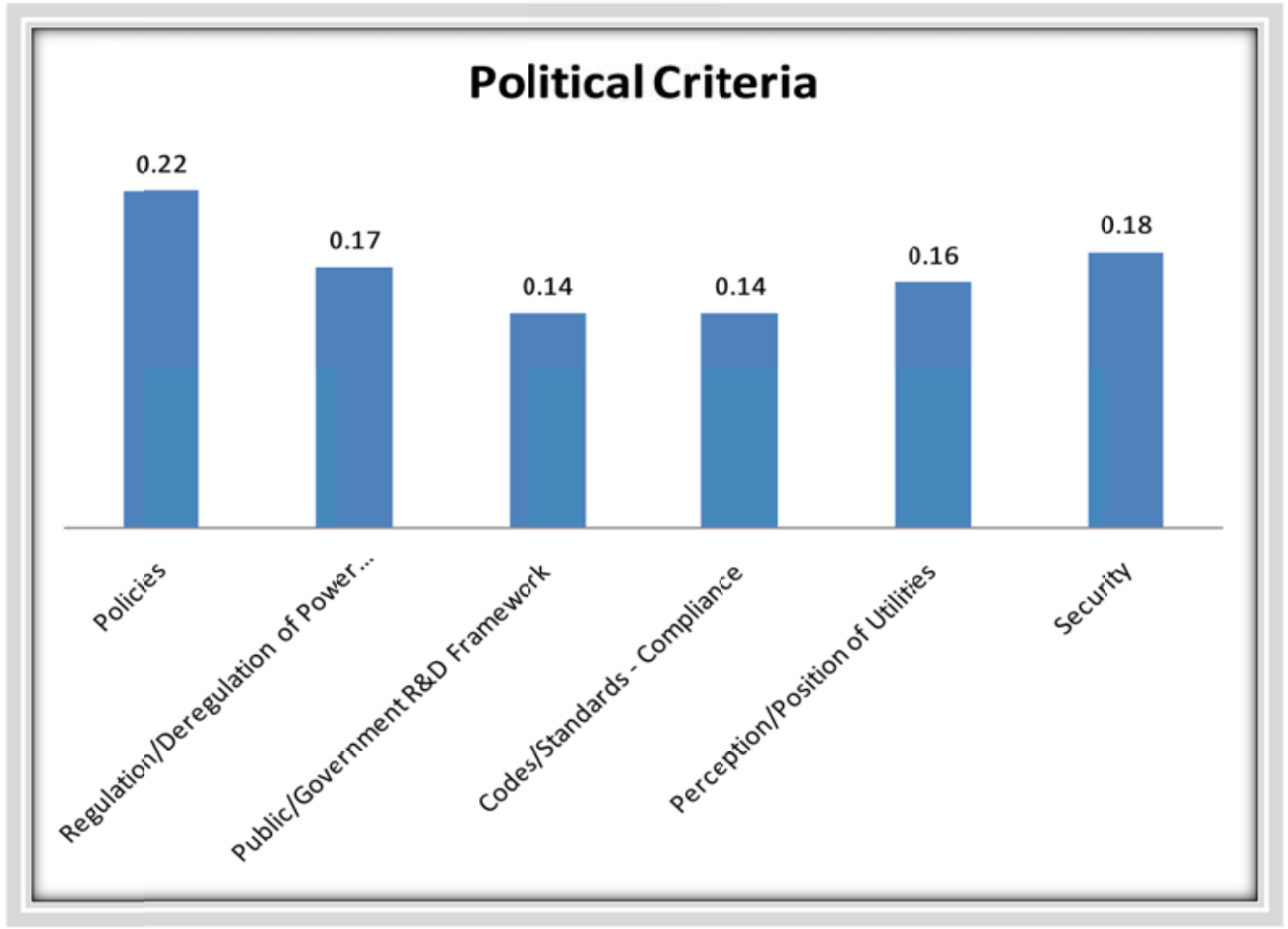

Figure 27: Political Perspective 
Table 17: Highest and Lowest Criteria in Relative Importance to Each Perspective

\begin{tabular}{|l|l|l|}
\hline Serspective & Highest Criteria & Lowest Criteria \\
\cline { 1 - 2 } & $\begin{array}{l}\text { Employment, } \\
\text { Health \& Safety }\end{array}$ & Local Infrastructure Development \\
\hline Technical & Efficiency & $\begin{array}{l}\text { Technology Maturity, } \\
\text { Codes/Standards Development }\end{array}$ \\
\hline Economic & Cost Mitigation & Positive Impact on Local Economy \\
\hline Political & $\begin{array}{l}\text { End-of-Life/Disposal, } \\
\text { Consumption of Resources }\end{array}$ & Pollution/Negative Impact \\
\hline
\end{tabular}

This HDM proved to be useful for subjective ranking of the perspectives and criteria for PV technology assessment.

\subsubsection{Initial Findings}

Initial results indicate interesting outcomes and provide insights into the actual explicit judgments of experts. (Refer to the section above). The initial results also helped in the clarification (or correction) of assumptions such as the Technical Perspective should be most important for those with a technology supplier or developer worldview. The initial results indicated that this may not be case (and in fact indicated that all five perspectives are relatively important) although more research is needed to validate or modify the findings.

The HDM model is a good method to obtain explicit judgments to better understand what is truly important for decision makers and experts. This model has the capability 
to be flexible and scalable with respect to multiple perspectives, multiple actors (decision makers, stakeholders, practitioners, end users, etc.), multiple criteria, and ability to provide guidance to practitioners and operational management. Hence it can provide assessment and direction. The HDM model helped in assessing individual and group rankings of the perspectives and criteria for better analysis. Experience in building, distributing, and obtaining feedback for the judgment quantification instrument was also gained through the test case.

Although initial results indicated that all five STEEP perspectives were important more research is needed to test out the some of the scenarios and cases mentioned in the Initial Results and Analysis section above. Gaining insight into what is required for next steps would be more difficult without the use of HDM. Through further surveys and analyses we will be able to arrive at a robust evaluation of the criteria and perspectives. Another step would be to determine desirability functions for each subcriterion or factor. The PV technology value (or score) can then be characterized by the composite of perspective, criteria, and factor values. This PV technology value could then be compared to the ideal value and also to its peer technologies. The author takes into account the initial findings from this study to develop the model, analyses, and results. 


\section{RESEARCH RESULTS}

This research process consisted of the following five major stages as explained in Section 4.3:

- Stage 1: Building of the Hierarchical Decision Model

- Stage 2: Expert Panel Selection

- Stage 3: Data Acquisition and Validation

- Stage 4: Analysis of the Results

- Stage 5: Sensitivity Analysis

\subsection{Stage 1: Building of the Hierarchical Decision Model}

The initial HDM defined in Chapter 6 was critically examined by the author to select only the criteria and factors that fit the following considerations:

- Only those criteria and factors were selected that could be used for the comparison of PV technologies and not disparate renewable energy source types such as solar PV, solar concentrators, wind, hydroelectric, biomass, and wave. Many of the HDM elements of the initial model did not provide meaningful differentiation when considering only PV technologies. For example, the public perception criterion under the social perspective and its related 13 factors provided were all the same for any type of PV technology and hence were not included in the model at this stage (Table 18). 
Table 18: Public Perception Criteria and its Factors

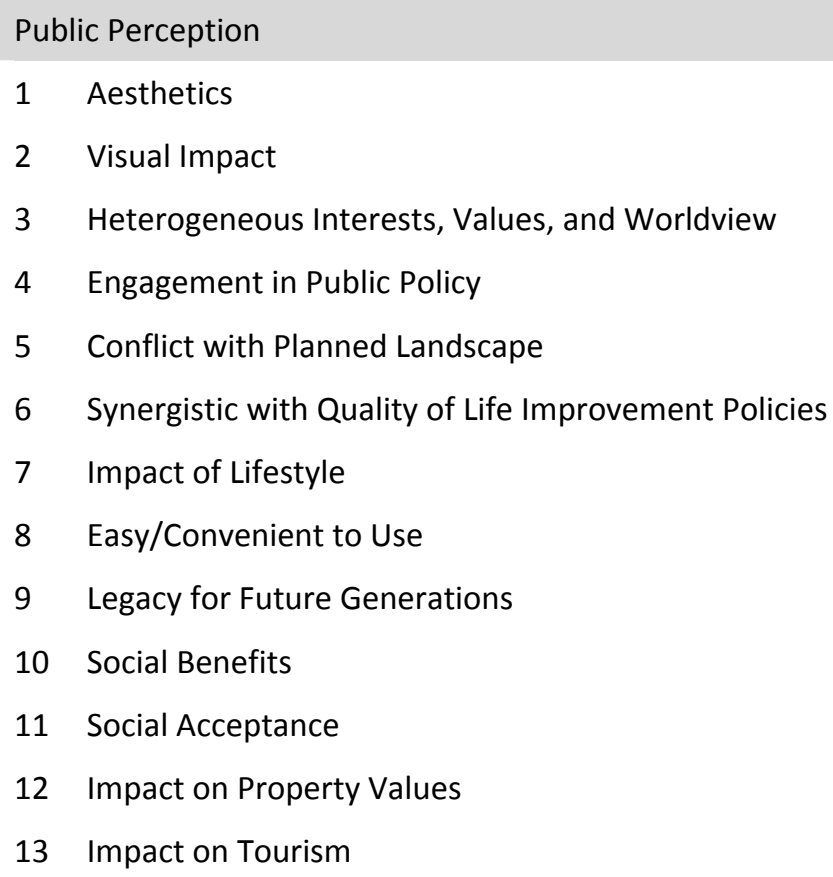

- The factors could be easily measured and tested by creating a measurement scale. This scale is required for the construction of the desirability functions. Furthermore, the expert panels would need to be familiar with the measures in order to apply their judgments. Considering the above example of the public perception factors, it would have been very difficult to provide measurement scales. How can we measure "social acceptance" for different PV technologies?

This exercise resulted in thirty-three criteria with the composition shown in Figure 28 below. 


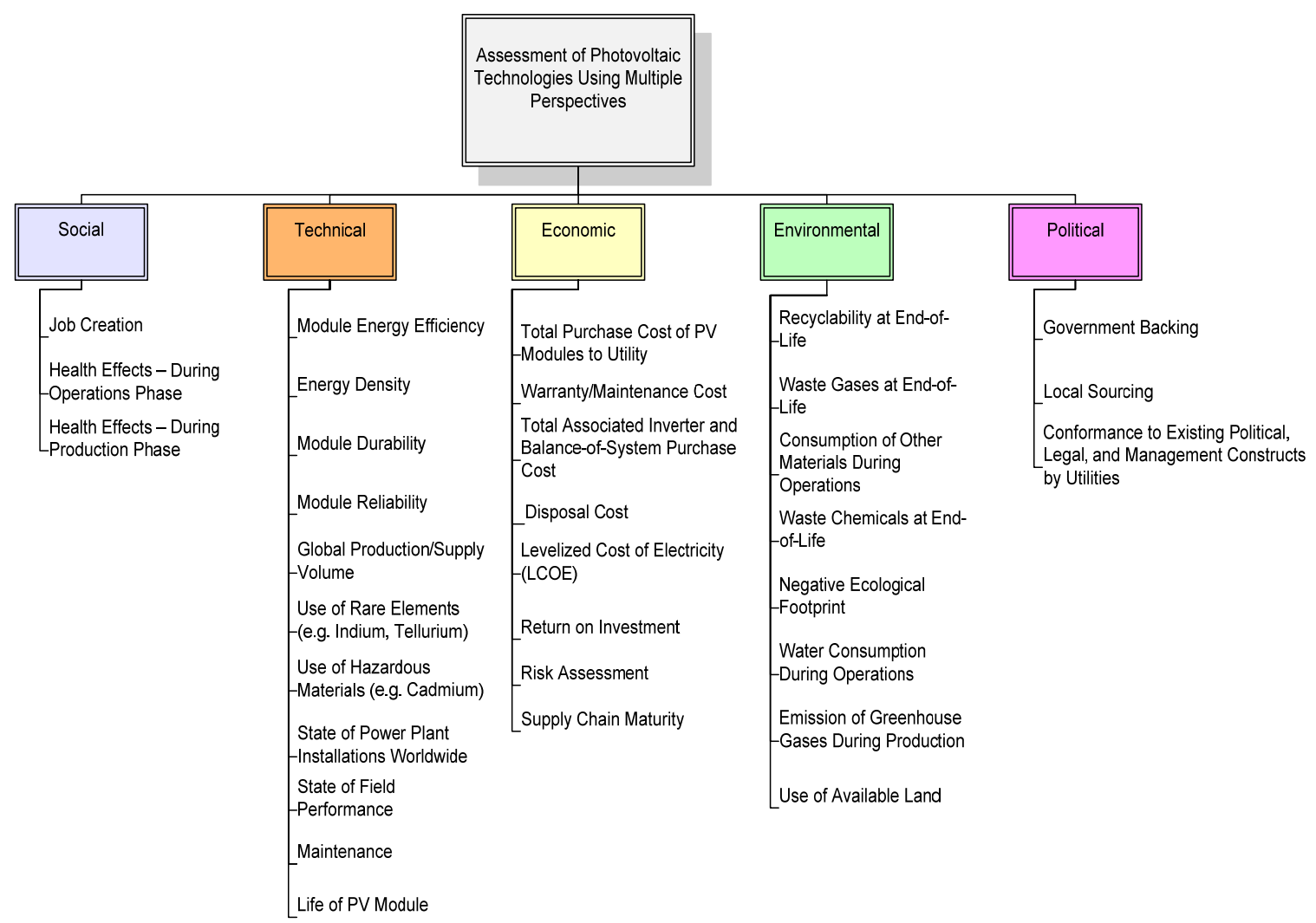

Figure 28: Intermediate Hierarchical Decision Model Reduced to 33 Criteria and No Factors

This was an intermediate stage since this model had to be verified by the experts. An instrument entitled, "Criteria Validation Research Instrument" was used via the webbased judgment elicitation software to gain feedback from the experts. A two-thirds (67\%) consensus process was used to include the criterion in the model. A form of the instrument template is provided in Appendix C. The criteria validation research Instrument was then augmented by another instrument to obtain feedback on additional criteria suggested by experts. Again, if two-thirds (67\%) of experts agreed to the new criterion it was included in the model. The experts also suggested correcting the placement of some of the criteria. For example, the criterion "use of rare 
elements" was moved from the technical to the economic perspective. The final HDM

consisted of thirty-nine criteria. This is shown in Figure 29 and described in Table 19.

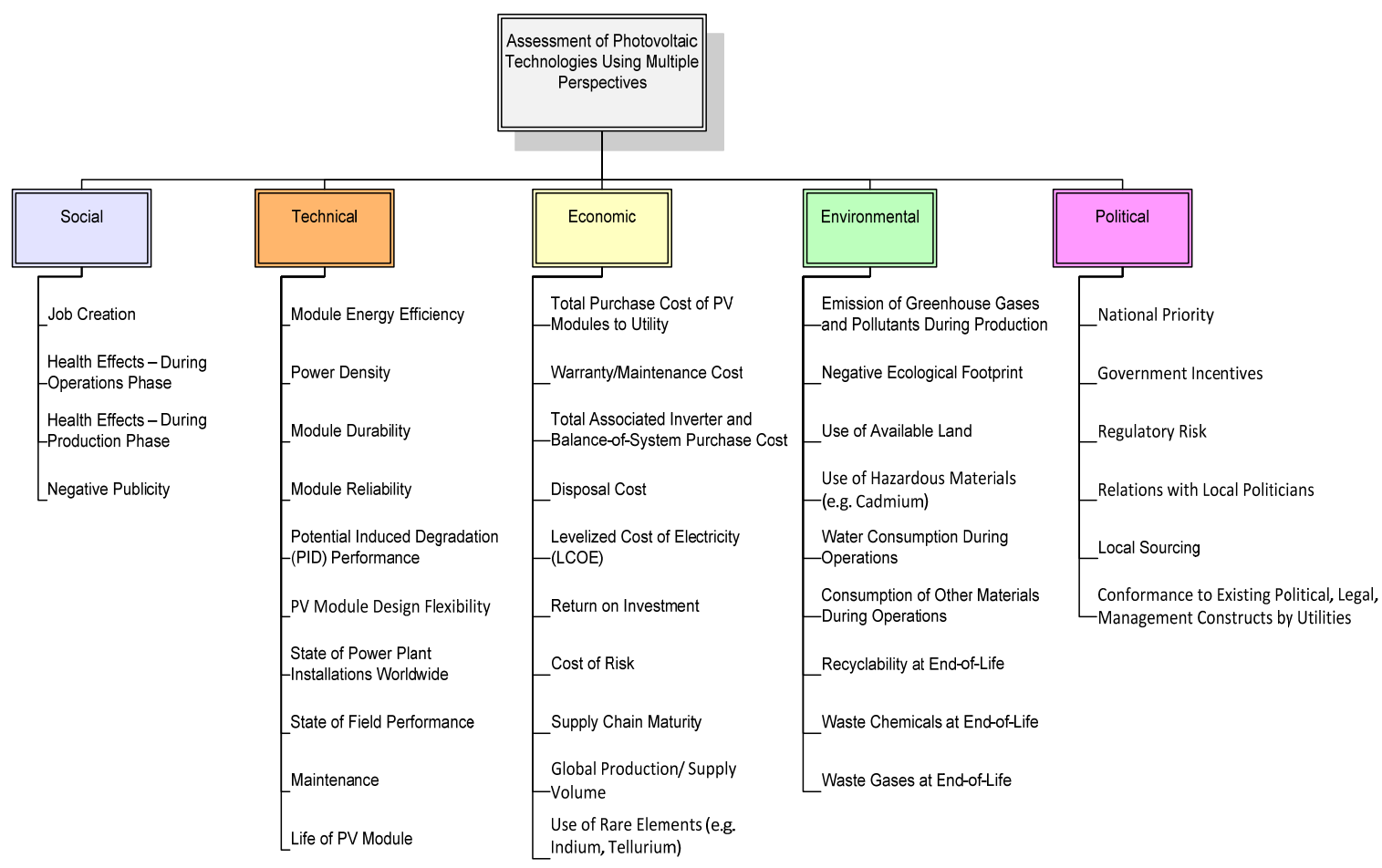

Figure 29: Final Hierarchical Decision Model with 39 Criteria and No Factors

Table 19: Final STEEP Criteria

\begin{tabular}{|l|l|l|l|}
\hline & Perspective & Criteria & Description \\
\hline 1. & Social (4) & S1: Job Creation & $\begin{array}{l}\text { Job creation is a top priority for many communities. } \\
\text { Certain PV technologies may be produced locally within } \\
\text { the utility's service area. Jobs are created for } \\
\text { production, installation, and operations. }\end{array}$ \\
\hline 2. & & $\begin{array}{l}\text { S2: Health Effects - } \\
\text { During Production } \\
\text { Phase }\end{array}$ & Negative health effects. \\
\hline
\end{tabular}




\begin{tabular}{|c|c|c|c|}
\hline 3. & & $\begin{array}{l}\text { S3: Health Effects - } \\
\text { During Operations } \\
\text { Phase }\end{array}$ & Negative health effects. \\
\hline \multirow[t]{2}{*}{4.} & & $\begin{array}{l}\text { S4: Negative } \\
\text { Publicity }\end{array}$ & $\begin{array}{l}\text { Bad publicity associated with the specific PV } \\
\text { technology. }\end{array}$ \\
\hline & Technical (10) & & \\
\hline 5. & & $\begin{array}{l}\text { T1: Module Energy } \\
\text { Efficiency }\end{array}$ & $\begin{array}{l}\text { PV Module or Panel Efficiency (\%) - percentage of light } \\
\text { energy that hits the module and gets converted into } \\
\text { electricity. A } 1 \mathrm{~m} \times 1.5 \mathrm{~m} \text { module or panel made of } 20 \% \\
\text { efficient cells would receive } 1.5 \mathrm{~kW} \text { of energy from the } \\
\text { sun and convert it to a } 300 \text { watt output. } \\
\text { [Note: Standardized measurement conditions specify a } \\
\text { temperature of } 25^{\circ} \mathrm{C} \text { and an irradiance of } 1000 \mathrm{~W} / \mathrm{m}^{2} \\
\text { with an air mass } 1.5 \text {. These correspond to the } \\
\text { irradiance and spectrum of sunlight incident on a clear } \\
\text { day upon a sun-facing } 37^{\circ} \text {-tilted surface with the sun at } \\
\text { an angle of } 41.81^{\circ} \text { above the horizon. This represents } \\
\text { solar noon near the spring and autumn equinoxes in } \\
\text { the continental United States with the cell aimed } \\
\text { directly at the sun.] }\end{array}$ \\
\hline 6. & & T2: Power Density & $\begin{array}{l}\text { The power density of a PV module or panel is the } \\
\text { efficiency described in terms of peak power output per } \\
\text { unit of surface area in } \mathrm{W} / \mathrm{ft}^{2} \text { or } \mathrm{W} / \mathrm{m}^{2} \text {. High-efficiency } \\
\mathrm{PV} \text { panels have energy densities greater than } 13 \mathrm{~W} / \mathrm{ft}^{2} \\
\text { or } 140 \mathrm{~W} / \mathrm{m}^{2} \text {. }\end{array}$ \\
\hline 7. & & $\begin{array}{l}\text { T3: Module } \\
\text { Durability }\end{array}$ & $\begin{array}{l}\text { Durability can be defined as avoidance of loss of } \\
\text { desirable properties resulting in declining performance } \\
\text { and shortened service lifetime. PV durability is } \\
\text { environmental durability and is a measure of the } \\
\text { retention of original condition and function of a } \\
\text { material after exposure to weather conditions. A PV } \\
\text { module is considered to be durable if it maintains at } \\
\text { least } 80 \% \text { of its original performance after } 25 \text { years. }\end{array}$ \\
\hline 8. & & $\begin{array}{l}\text { T4: Module } \\
\text { Reliability }\end{array}$ & $\begin{array}{l}\text { Module reliability is the module's performance of its } \\
\text { intended function during its lifetime. Reliability } \\
\text { measure relates to absolute failures. }\end{array}$ \\
\hline
\end{tabular}




\begin{tabular}{|c|c|c|c|}
\hline 9. & & $\begin{array}{l}\text { T5: Potential } \\
\text { Induced } \\
\text { Degradation (PID) } \\
\text { Performance }\end{array}$ & $\begin{array}{l}\text { PID has become a major concern in the solar industry as } \\
\text { it can significantly reduce the power output of a PV } \\
\text { system. Inherent differences in voltage between the } \\
\text { module framework and solar cells as well as } \\
\text { environmental conditions such as increased humidity } \\
\text { and higher temperatures can lead to degradation over } \\
\text { the life cycle of the module. This reduces the yield of a } \\
\text { PV system. } \\
\text { [During the tests performed by TUV Rheinland and PV } \\
\text { Lab, a negative voltage of } 1,000 \text { Volts is applied to the } \\
\text { modules at an ambient room temperature ( } 25 \text { degrees } \\
\text { Celsius) and humidity over a period of } 7 \text { days (168 } \\
\text { hours). The module front is covered with aluminum foil } \\
\text { or a constant water film to minimize the resistivity with } \\
\text { the grounded frame. According to both laboratories, if } \\
\text { a module's performance declines by less than five } \\
\text { percent under test conditions it is deemed to have } \\
\text { passed the test.] }\end{array}$ \\
\hline 10. & & $\begin{array}{l}\text { T6: PV Module } \\
\text { Design Flexibility }\end{array}$ & $\begin{array}{l}\text { PV module or panel geometries and other design } \\
\text { considerations may be important for location-based } \\
\text { deployments. }\end{array}$ \\
\hline 11. & & $\begin{array}{l}\text { T7: State of Power } \\
\text { Plant Installation } \\
\text { Worldwide }\end{array}$ & $\begin{array}{l}\text { Is this PV technology deployed by electric utilities } \\
\text { anywhere in the world? Electric utilities prefer to use } \\
\text { technologies that have been proven in similar } \\
\text { applications. }\end{array}$ \\
\hline 12. & & $\begin{array}{l}\text { T8: State of Field } \\
\text { Performance }\end{array}$ & How long has this PV technology been field tested? \\
\hline 13. & & $\begin{array}{l}\text { T9: Maintenance } \\
\text { Required }\end{array}$ & $\begin{array}{l}\text { The level of maintenance required to ensure that PV } \\
\text { module is in proper working condition. }\end{array}$ \\
\hline 14. & & T10: Life of PV Panel & $\begin{array}{l}\text { This represents the duration of useful life of the PV } \\
\text { module. }\end{array}$ \\
\hline & Economic (10) & & \\
\hline 15. & & $\begin{array}{l}\text { E1: Total Purchase } \\
\text { Cost of PV Panels to } \\
\text { Utility }\end{array}$ & $\begin{array}{l}\text { In volume purchase the current price of crystalline } \\
\text { silicon-based PV panels is about } \$ 1-2 / W(2012) \text {. }\end{array}$ \\
\hline
\end{tabular}




\begin{tabular}{|c|c|c|}
\hline 16. & $\begin{array}{l}\text { E2: Warranty/ } \\
\text { Maintenance Cost }\end{array}$ & $\begin{array}{l}\text { Warranty may vary from } 10 \text { to } 25 \text { years with varying } \\
\text { performance levels. To maintain the systems at peak } \\
\text { performance level the utility needs in-house or } \\
\text { contracted maintenance. }\end{array}$ \\
\hline 17. & $\begin{array}{l}\text { E3: Total Associated } \\
\text { Inverter and } \\
\text { Balance-of-System } \\
\text { Purchase Cost }\end{array}$ & $\begin{array}{l}\text { The Balance-of-System (BOS) includes everything } \\
\text { beyond the PV module for a solar system such as the } \\
\text { inverter(s) (or micro-inverters), the electrical system, } \\
\text { and the structural system for mounting. In volume } \\
\text { purchase the current price of crystalline silicon-based } \\
\text { PV BOS is about } \$ 1.5 \text { - 3/W (2012). }\end{array}$ \\
\hline 18. & E4: Disposal Cost & $\begin{array}{l}\text { This is the disposal cost at end of life of a PV panel. A } \\
\text { typical silicon-based PV panel cost of disposal is } \\
\text { estimated to be about } \$ 0.60 \text { for a } 200 \mathrm{~W} \text { panel. }\end{array}$ \\
\hline 19. & $\begin{array}{l}\text { E5: Levelized Cost of } \\
\text { Electricity (LCOE) }\end{array}$ & $\begin{array}{l}\text { The levelized cost of electricity (LCOE) is considered the } \\
\text { most important metric for renewable energy utility } \\
\text { systems. It is also referred to as "levelized cost of } \\
\text { energy." LCOE is the price at which electricity must be } \\
\text { generated from an energy source to break even over } \\
\text { the utility system lifetime. It typically includes all the } \\
\text { lifetime investment costs, capitals costs, operations } \\
\text { costs, and disposal costs. A scalable PV design capable } \\
\text { of achieving LCOE under } \$ 0.10 / \text { kWh unsubsidized } \\
\text { becomes cheaper than retail electricity in many U.S. } \\
\text { markets. Currently LCOE varies greatly and may range } \\
\text { from } \$ 0.15 / \mathrm{kWh} \text { to higher values. }\end{array}$ \\
\hline 20. & $\begin{array}{l}\text { E6: Return on } \\
\text { Investment }\end{array}$ & $\begin{array}{l}\text { Lifetime return on investment based on internal rate of } \\
\text { return (IRR). }\end{array}$ \\
\hline 21. & E7: Cost of Risk & $\begin{array}{l}\text { The cost of risk in using PV system as electric utility. } \\
\text { Risk may include cost of downtime/maintenance and } \\
\text { the cleanup of negative environmental impact during } \\
\text { operations such as leakage of hazardous materials. }\end{array}$ \\
\hline 22. & $\begin{array}{l}\text { E8: Supply Chain } \\
\text { Maturity }\end{array}$ & $\begin{array}{l}\text { Distribution and Supply Chain is important for the } \\
\text { buyer of PV panels and associated balance of systems. } \\
\text { The maturity levels of the supply chain may vary from } \\
\text { "ad hoc" where practices are unstructured to } \\
\text { "extended" where multiple firms compete for business. } \\
\text { The following defines the supply chain levels: } \\
\text { - Extended - Firms at the extended level have } \\
\text { multiple supply chains competing for the business }\end{array}$ \\
\hline
\end{tabular}




\begin{tabular}{|c|c|c|c|}
\hline & & & $\begin{array}{l}\text { and working together with a customer focus. This is } \\
\text { the highest level of supply chain maturity. } \\
\text { - Integrated - At this level supply chain management } \\
\text { systems are integrated and well defined. Production } \\
\text { planning and forecasting are established. } \\
\text { Established firms are typically at this level. } \\
\text { - } \text { Linked - The linked level sets the supply chain on a } \\
\text { strategic path by enabling stronger relationships } \\
\text { between partners and defined structures and roles. } \\
\text { Defined - At this level firms are developing supply } \\
\text { chain supply chain relationships and have } \\
\text { management processes. Supply chain performance, } \\
\text { management costs, and customer satisfaction is } \\
\text { improving. However, lack of integration makes } \\
\text { cooperation between supply chain members } \\
\text { difficult. } \\
\text { Ad Hoc - The ad hoc level or stage is usually } \\
\text { associated with start-ups with unstructured } \\
\text { management practices and no measurement } \\
\text { processes established. This typically results in } \\
\text { unpredictable supply chain performance, higher } \\
\text { management costs, and low customer satisfaction. } \\
\text { This is the lowest level of supply chain maturity. }\end{array}$ \\
\hline 23. & & $\begin{array}{l}\text { E9: Global } \\
\text { Production/Supply } \\
\text { Volume }\end{array}$ & $\begin{array}{l}\text { Global production volume can affect price, supply, and } \\
\text { timely replacement of PV panels and systems. }\end{array}$ \\
\hline \multirow[t]{2}{*}{24.} & & $\begin{array}{l}\text { E10: Use of Rare } \\
\text { Elements (e.g. } \\
\text { Indium, Tellurium) }\end{array}$ & $\begin{array}{l}\text { Using rare element materials may be an issue due to } \\
\text { their scarcity and restrictive access. }\end{array}$ \\
\hline & $\begin{array}{l}\text { Environmental } \\
\text { (9) }\end{array}$ & & \\
\hline 25. & & $\begin{array}{l}\text { N1: Emission of } \\
\text { Greenhouse Gases } \\
\text { and Pollutants } \\
\text { During Production }\end{array}$ & $\begin{array}{l}\text { Governments are encouraging sustainability and are } \\
\text { restricting greenhouse gas (GHG) emissions and } \\
\text { pollutants such as } \mathrm{CO}_{2}, \mathrm{NO}_{x} \text {, and } \mathrm{SO}_{x} \text {. In the future } \\
\text { utilities may consider this as a factor for evaluation of } \\
\text { PV technologies. }\end{array}$ \\
\hline 26. & & $\begin{array}{l}\text { N2: Negative } \\
\text { Ecological Footprint }\end{array}$ & $\begin{array}{l}\text { How much of a negative impact does the deployment } \\
\text { of a PV technology have on the underlying and } \\
\text { surrounding crops, woods, etc.? }\end{array}$ \\
\hline 27. & & $\begin{array}{l}\text { N3: Use of Available } \\
\text { Land }\end{array}$ & $\begin{array}{l}\text { In many parts of the world land is a scarce resource and } \\
\text { better utilization by a PV technology is a consideration. } \\
\text { A combination of PV module power density and }\end{array}$ \\
\hline
\end{tabular}




\begin{tabular}{|c|c|c|c|}
\hline & & & $\begin{array}{l}\text { adherence to buildings or landscape geometries need } \\
\text { to be considered for efficient use of available terrain. } \\
\text { For example a thin-film PV technology with power } \\
\text { density of } 100 \mathrm{~W} / \mathrm{m}^{2} \text { is only half as efficient in land use } \\
\text { as a crystalline silicone (c-Si) PV technology with } 200 \\
\mathrm{~W} / \mathrm{m}^{2} \text {. This is because twice the area is needed for the } \\
\text { thin-film PV. }\end{array}$ \\
\hline 28. & & $\begin{array}{l}\text { N4: Use of } \\
\text { Hazardous Materials } \\
\text { (e.g. Cadmium) }\end{array}$ & $\begin{array}{l}\text { Using hazardous materials may be an issue if there is } \\
\text { accidental leakage or contact with humans or animals. }\end{array}$ \\
\hline 29. & & $\begin{array}{l}\text { N5: Water } \\
\text { Consumption } \\
\text { During Operations }\end{array}$ & $\begin{array}{l}\text { Water consumption may be required for cooling or } \\
\text { cleaning of PV technologies during operations. }\end{array}$ \\
\hline 30. & & $\begin{array}{l}\text { N6: Consumption of } \\
\text { Other Materials } \\
\text { During Operations }\end{array}$ & $\begin{array}{l}\text { Materials in addition to water such as panel cleaning } \\
\text { solvents, protective panel coatings, and herbicides may } \\
\text { be consumed during operations. }\end{array}$ \\
\hline 31. & & $\begin{array}{l}\text { N7: Recyclability at } \\
\text { End-of-Life }\end{array}$ & $\begin{array}{l}\text { Disposal of PV systems at the end-of-life are more } \\
\text { attractive if the component materials can be easily } \\
\text { recycled. }\end{array}$ \\
\hline 32. & & $\begin{array}{l}\text { N8: Waste } \\
\text { Chemicals at End-of- } \\
\text { Life }\end{array}$ & $\begin{array}{l}\text { Waste chemicals may be released by the disposal of PV } \\
\text { systems. }\end{array}$ \\
\hline \multirow[t]{2}{*}{33.} & & $\begin{array}{l}\text { N9: Waste Gases at } \\
\text { End-of-Life }\end{array}$ & $\begin{array}{l}\text { Waste gases may be released by the disposal of PV } \\
\text { systems. }\end{array}$ \\
\hline & Political (6) & & \\
\hline 34. & & P1: National Priority & $\begin{array}{l}\text { National importance of the PV technology under } \\
\text { consideration. }\end{array}$ \\
\hline 35. & & $\begin{array}{l}\text { P2: Government } \\
\text { Incentives }\end{array}$ & $\begin{array}{l}\text { Government support through financing, tariffs, and } \\
\text { other incentives and preferences can affect the } \\
\text { selection of a PV technology. }\end{array}$ \\
\hline 36. & & P3: Regulatory Risk & $\begin{array}{l}\text { Regulatory hurdles or risks associated with permitting } \\
\text { requirements. }\end{array}$ \\
\hline 37. & & $\begin{array}{l}\text { P4: Relations with } \\
\text { Local Politicians }\end{array}$ & Support or opposition by local politicians. \\
\hline
\end{tabular}




\begin{tabular}{|l|l|l|l|}
\hline 38. & P5: Local Sourcing & $\begin{array}{l}\text { If the PV technology uses local sourcing it could } \\
\text { increase the local or regional support. For example, } \\
\text { Canada requires partial local sourcing of renewable } \\
\text { energy equipment for feed-in tariffs to be applicable. }\end{array}$ \\
\hline 39. & $\begin{array}{l}\text { P6: Conformance to } \\
\text { Existing Political, } \\
\text { Legal, Management } \\
\text { Constructs by } \\
\text { Utilities }\end{array}$ & $\begin{array}{l}\text { Utilities are accustomed to established business or } \\
\text { regulatory practices and change is difficult. }\end{array}$ \\
\hline
\end{tabular}

\subsection{Stage 2: Expert Panel Selection}

In practice this stage was in parallel to Stage 1 to ensure that the HDM model and criteria were formed with input from the experts. The expert panel selection process is described in Chapter 4.

A total of thirty-three experts were engaged and they participated in various aspects of this research. For example, one expert helped to validate the model and criteria for the social and political perspectives. He or she also provided his or her judgment to rank the criteria as well as assist in building the desirability functions for the same perspectives. Another expert only focused on the technical perspective. The qualifications and positions of the experts are listed in Table 20. The average experience level of the experts was over twenty years. 
Table 20: Qualifications and Positions of the Experts

\begin{tabular}{|c|c|c|}
\hline & Position/Title/Role of Expert & Organization \\
\hline 1. & $\begin{array}{l}\text { Department General Manager, Environmental } \\
\text { Technology Development Center, Solar System } \\
\text { Group }\end{array}$ & $\begin{array}{l}\text { Multinational solar PV and electronics } \\
\text { manufacturer, Japan }\end{array}$ \\
\hline 2. & Director & Solar Institute, United States \\
\hline 3. & $\begin{array}{l}\text { Former Manager, Cloud Computing Technology } \\
\text { Development Center, Corporate R\&D Group }\end{array}$ & $\begin{array}{l}\text { Multinational solar PV and electronics } \\
\text { manufacturer, Japan }\end{array}$ \\
\hline 4. & $\begin{array}{l}\text { Professor with research in solar and renewable } \\
\text { energy }\end{array}$ & Polytechnic institute, Italy \\
\hline 5. & Project Manager & $\begin{array}{l}\text { Northwest electric utility, United } \\
\text { States }\end{array}$ \\
\hline 6. & Chief Technical Specialist & $\begin{array}{l}\text { Research laboratory of a multinational } \\
\text { solar PV and electronics manufacturer, } \\
\text { United States }\end{array}$ \\
\hline 7. & $\begin{array}{l}\text { Operations Research Director with research in solar } \\
\text { PV }\end{array}$ & Department of Defense, United States \\
\hline 8. & $\begin{array}{l}\text { Solar PV Systems Consultant for technical and } \\
\text { economic feasibility }\end{array}$ & Independent consultant, United States \\
\hline 9. & $\begin{array}{l}\text { Professor with research in solar and renewable } \\
\text { energy }\end{array}$ & Technical university, Greece \\
\hline 10. & $\begin{array}{l}\text { Professor with research in solar and renewable } \\
\text { energy }\end{array}$ & Polytechnic institute, Italy \\
\hline 11. & Associate Manager, Energy Policy & $\begin{array}{l}\text { United States Chamber of Commerce, } \\
\text { United States }\end{array}$ \\
\hline 12. & $\begin{array}{l}\text { Professor with research in solar and renewable } \\
\text { energy }\end{array}$ & University, Sweden \\
\hline 13. & $\begin{array}{l}\text { Professor with research in solar and renewable } \\
\text { energy }\end{array}$ & University, Netherlands \\
\hline 14. & Engineering Manager and PV thin film materials & Solar PV firm, United States \\
\hline 15. & Founder and CEO & $\begin{array}{l}\text { Energy management startup } \\
\text { monitoring solar and renewable } \\
\text { energy installations, United States }\end{array}$ \\
\hline 16. & Director, Strategic Energy Analysis & $\begin{array}{l}\text { National Renewable Energy } \\
\text { Laboratory, United States }\end{array}$ \\
\hline 17. & Solar PV Systems Consultant & Independent consultant, United States \\
\hline 18. & $\begin{array}{l}\text { Professor and Director Photovoltaics Centre of } \\
\text { Excellence }\end{array}$ & University, Australia \\
\hline 19. & $\begin{array}{l}\text { Adjunct Associate Professor with research in } \\
\text { renewable energy and energy management }\end{array}$ & University, United States \\
\hline
\end{tabular}




\begin{tabular}{|r|l|l|}
\hline 20. & $\begin{array}{l}\text { Professor with research in solar and renewable } \\
\text { energy planning }\end{array}$ & University, Denmark \\
\hline 21. & Professor and Director of Solar Energy Center & University, United States \\
\hline 22. & Head of Crystal Growing and Wafer Department & $\begin{array}{l}\text { Multinational solar PV manufacturer, } \\
\text { United States }\end{array}$ \\
\hline 23. & $\begin{array}{l}\text { Professor and Project Director with interdisciplinary } \\
\text { research in buildings, energy, and environment }\end{array}$ & University, United States \\
\hline 24. & $\begin{array}{l}\text { Director of Business Model and Program } \\
\text { Development }\end{array}$ & $\begin{array}{l}\text { Northwest electric utility, United } \\
\text { States }\end{array}$ \\
\hline 25. & $\begin{array}{l}\text { Professor with interdisciplinary research on risk } \\
\text { governance and sustainable technology development }\end{array}$ & University, Germany \\
\hline 26. & $\begin{array}{l}\text { Renewable Energy and Low Carbon Investment } \\
\text { Consultant }\end{array}$ & Independent consultant, United States \\
\hline 27. & $\begin{array}{l}\text { Associate Professor with research in solar technology } \\
\text { and society, }\end{array}$ & University, Austria \\
\hline 28. & $\begin{array}{l}\text { Associate Professor with research in solar and } \\
\text { renewable energy }\end{array}$ & University, Italy \\
\hline 29. & $\begin{array}{l}\text { Research scientist with research in solar and } \\
\text { renewable energy }\end{array}$ & University, Italy \\
\hline 30. & Researcher & $\begin{array}{l}\text { Multinational solar PV inverter } \\
\text { manufacturer }\end{array}$ \\
\hline 31. & Former CEO and Founder & $\begin{array}{l}\text { Research laboratory of a multinational } \\
\text { solar PV and electronics manufacturer, } \\
\text { United States }\end{array}$ \\
\hline Senior Scientist, Renewable Energy & Senior Vice President & $\begin{array}{l}\text { Institute of Energy, European } \\
\text { Commission, Italy }\end{array}$ \\
\hline
\end{tabular}

The experts formed six panels and completed a web-based research instrument for pairwise comparisons of the criteria. The number of experts for each perspective varied and is indicated in Table 21. 
Table 21: Number of Experts for Each Panel Type

\begin{tabular}{|c|l|c|}
\hline Expert Panel Type & $\begin{array}{l}\text { Number of Experts/ } \\
\text { Decision Makers }\end{array}$ \\
\hline 1. & $\begin{array}{l}\text { Decision makers to rank the perspectives for the northwest United } \\
\text { States electric utility worldview }\end{array}$ & 3 \\
\hline 2. & $\begin{array}{l}\text { Social scientists to rank the contribution of each criterion to the } \\
\text { social perspective }\end{array}$ & 10 \\
\hline 3. & $\begin{array}{l}\text { Technologists and engineers to rank the contribution of each } \\
\text { criterion to the technical perspective }\end{array}$ & 11 \\
\hline 4. & $\begin{array}{l}\text { Economists to rank the contribution of each criterion to the } \\
\text { economic perspective }\end{array}$ & 12 \\
\hline 5. & $\begin{array}{l}\text { Environmental scientists to rank the contribution of each criterion } \\
\text { to the environmental perspective }\end{array}$ & 9 \\
\hline 6. & $\begin{array}{l}\text { Political scientists to rank the contribution of each criterion to the } \\
\text { political perspective }\end{array}$
\end{tabular}

The experts were also requested to provide their judgments for building the desirability functions for each criterion. In this case the number of experts is listed in

Table 22.

Table 22: Number of Experts for Criteria Desirability Functions

\begin{tabular}{|c|l|c|}
\hline & $\begin{array}{l}\text { Expert Panel for Criteria Desirability } \\
\text { Functions }\end{array}$ & Number of Experts \\
\hline 1. & Social perspective & 11 \\
\hline 2. & Technical perspective & 13 \\
\hline 3. & Economic perspective & 8 \\
\hline 4. & Environmental perspective & 8 \\
\hline 5. & Political perspective & 8 \\
\hline
\end{tabular}

Lastly, three experts, through unanimous consensus, provided the desirability values for the five candidate PV technologies under consideration for the case study. These PV technologies included: c-Si, a-Si, CIGS, CdTe, and OPV. These technologies were 
selected because the first four represent the most commonly deployed technologies and OPV represents an emerging desired technology. Hence, all five can be compared and contrasted across the STEEP perspectives.

\subsection{Stage 3: Data Acquisition and Validation}

\subsubsection{Ranking of STEEP Perspectives: Electric Utility Worldview}

The case of a Northwest United States electric utility worldview was considered for the relative ranking of the perspectives. The decision makers' panel was composed of three experts and they were requested to evaluate the relative priorities of the five perspectives in fulfilling the mission of PV technology assessment. Based on all three experts, the arithmetic mean of the relative priority of the perspectives to the mission and the levels of inconsistency and disagreement for the experts were obtained. The arithmetic mean of the panel's evaluation is used to represent the relative ranking of the perspectives. The results are shown in Table 23.

Table 23: Relative Ranking of Perspectives in Fulfilling the Mission

\begin{tabular}{|c|c|c|c|c|c|c|}
\hline $\begin{array}{c}\text { Assessment of PV } \\
\text { Technologies from NW } \\
\text { Electric Utility } \\
\text { Worldview (EUVW) }\end{array}$ & 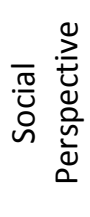 & 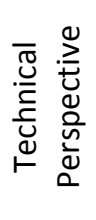 & 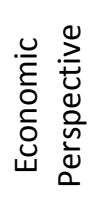 & 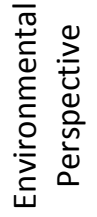 & 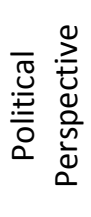 & 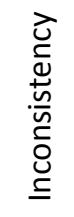 \\
\hline Ex1-EUWV & 0.09 & 0.32 & 0.32 & 0.17 & 0.09 & 0.01 \\
\hline Ex2-EUWV & 0.12 & 0.11 & 0.41 & 0.21 & 0.14 & 0.01 \\
\hline Ex3-EUWV & 0.20 & 0.25 & 0.29 & 0.19 & 0.07 & 0.07 \\
\hline Mean & 0.14 & 0.23 & 0.34 & 0.19 & 0.10 & \\
\hline Minimum & 0.09 & 0.11 & 0.29 & 0.17 & 0.07 & \\
\hline Maximum & 0.2 & 0.32 & 0.41 & 0.21 & 0.14 & \\
\hline Standard Deviation & 0.05 & 0.09 & 0.05 & 0.02 & 0.03 & \\
\hline
\end{tabular}




\begin{tabular}{|c|l|l|l|l|l|l|}
\hline Disagreement & & & & & & 0.05 \\
\hline
\end{tabular}

\begin{tabular}{|l|c|c|c|c|}
\hline \multicolumn{5}{|c|}{ Assessment of PV Technologies from NW Electric Utility Worldview } \\
(EUVW)
\end{tabular}

The decision makers considered the economic perspective as the most important followed by the technical perspective. The political perspective was considered the least important with respect to the comparison of PV technologies. However, all five perspectives made at least $10 \%(0.1)$ contribution to the mission, implying that they were all significant. The relative ranking of the perspectives is shown in Table 24.

Table 24: Relative Ranking of the Perspectives in Comparison to the Best

\begin{tabular}{|l|c|c|c|c|c|}
\hline Perspective & Social & Technical & Economic & Environmental & Political \\
\hline Mean Relative Value & 0.14 & 0.23 & 0.34 & 0.19 & 0.10 \\
\hline Ratio With Respect to Best & 0.40 & 0.70 & 1.00 & 0.60 & 0.50 \\
\hline
\end{tabular}

\subsubsection{Ranking of Social Perspective Criteria}

The social perspective expert panel consisted of ten experts. The experts evaluated the relative contribution of each criterion to the social perspective using pairwise comparison constant-sum method as defined earlier. The arithmetic mean of the panel's evaluation is used to represent the relative ranking of the criteria. The resulting 
arithmetic mean of their evaluations and the levels of inconsistency and disagreement are shown in Table 25. The Job Creation criterion was ranked the highest in terms of relative contribution to the social perspective.

Table 25: Relative Ranking of Social Criteria

\begin{tabular}{|c|c|c|c|c|c|}
\hline $\begin{array}{l}\text { Social Perspective } \\
\text { (S) }\end{array}$ & $\begin{array}{l}\text { ㄷ } \\
\stackrel{0}{+} \\
\frac{\pi}{0} \\
\stackrel{1}{U} \\
\text { 응 }\end{array}$ & 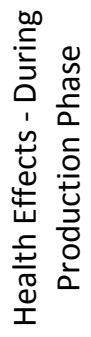 & 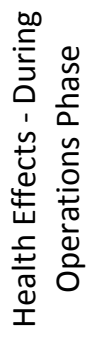 & 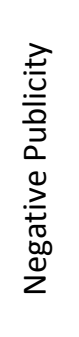 & 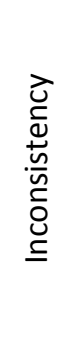 \\
\hline Ex1-S & 0.5 & 0.18 & 0.18 & 0.14 & 0 \\
\hline Ex2-S & 0.2 & 0.32 & 0.38 & 0.1 & 0.02 \\
\hline Ex3-S & 0.3 & 0.1 & 0.3 & 0.3 & 0 \\
\hline Ex4-S & 0.37 & 0.4 & 0.15 & 0.08 & 0.11 \\
\hline Ex5-S & 0.62 & 0.02 & 0.02 & 0.34 & 0.15 \\
\hline Ex6-S & 0.18 & 0.28 & 0.27 & 0.27 & 0 \\
\hline Ex7-S & 0.47 & 0.17 & 0.17 & 0.19 & 0 \\
\hline Ex8-S & 0.33 & 0.18 & 0.24 & 0.24 & 0.01 \\
\hline Ex9-S & 0.16 & 0.63 & 0.18 & 0.03 & 0.15 \\
\hline Ex10-S & 0.18 & 0.33 & 0.33 & 0.15 & 0 \\
\hline Mean & 0.33 & 0.26 & 0.22 & 0.18 & \\
\hline Minimum & 0.16 & 0.02 & 0.02 & 0.03 & \\
\hline Maximum & 0.62 & 0.63 & 0.38 & 0.34 & \\
\hline Standard Deviation & 0.15 & 0.16 & 0.1 & 0.1 & \\
\hline Disagreement & & & & & 0.13 \\
\hline
\end{tabular}




\begin{tabular}{|l|c|c|c|c|}
\hline \multicolumn{5}{|c|}{ Social Perspective } \\
\hline Source of Variation & $\begin{array}{c}\text { Sum of } \\
\text { Squares }\end{array}$ & $\begin{array}{c}\text { Degrees of } \\
\text { Freedom }\end{array}$ & Mean Square & $\begin{array}{c}\text { F-test } \\
\text { Value }\end{array}$ \\
\hline Between Criteria & 0.12 & 3 & .039 & 1.55 \\
\hline Between Experts & 0.00 & 9 & 0.000 & \\
\hline Residual & 0.69 & 27 & 0.025 & \\
\hline Total & 0.80 & 39 & & \\
\hline Critical F-value with degrees of freedom 3 \& 27 at 0.01 level: & 4.60 \\
\hline Critical F-value with degrees of freedom 3 \& 27 at 0.025 level: & 3.65 \\
\hline Critical F-value with degrees of freedom 3 \& 27 at 0.05 level: & 2.96 \\
\hline Critical F-value with degrees of freedom 3 \& 27 at 0.1 level: & 2.3 \\
\hline
\end{tabular}

\subsubsection{Ranking of Technical Perspective Criteria}

The technical perspective expert panel consisted of twelve experts. The experts evaluated the relative contribution of each criterion to the technical perspective using pairwise comparison constant-sum method as defined earlier. The arithmetic mean of the panel's evaluation is used to represent the relative ranking of the criteria. The resulting arithmetic mean of their evaluations and the levels of inconsistency and disagreement are shown in Table 26. The Potential Induced Degradation (PID) Performance criterion was ranked the highest in terms of relative contribution to the technical perspective. It should be noted that this particular criterion was suggested by the experts and had not been part of the initial criteria set. 
Table 26: Relative Ranking of Technical Criteria

\begin{tabular}{|c|c|c|c|c|c|c|c|c|c|c|c|}
\hline $\begin{array}{c}\text { Technical } \\
\text { Perspective (T) }\end{array}$ & 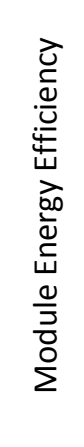 & 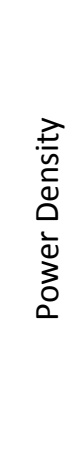 & 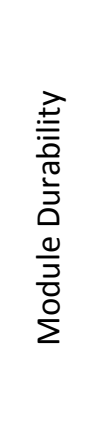 & 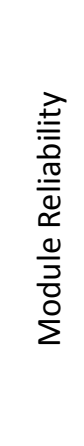 & 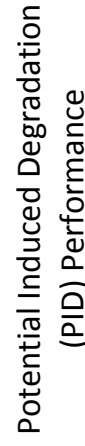 & 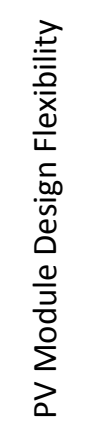 & 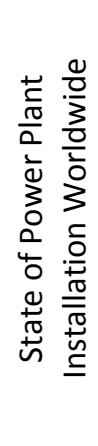 & 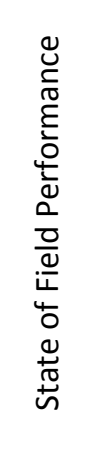 & 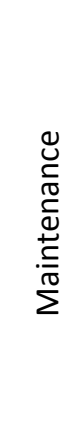 & 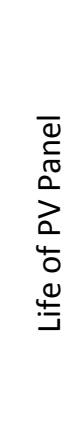 & 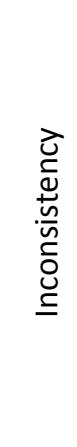 \\
\hline Ex1-T & 0.07 & 0.06 & 0.14 & 0.12 & 0.15 & 0.13 & 0.08 & 0.1 & 0.08 & 0.09 & 0.02 \\
\hline Ex2-T & 0.12 & 0.1 & 0.1 & 0.11 & 0.1 & 0.1 & 0.09 & 0.1 & 0.09 & 0.1 & 0 \\
\hline Ex3-T & 0.04 & 0.05 & 0.13 & 0.17 & 0.18 & 0.1 & 0.06 & 0.1 & 0.06 & 0.11 & 0.03 \\
\hline Ex4-T & 0.17 & 0.06 & 0.11 & 0.14 & 0.37 & 0.02 & 0.06 & 0.05 & 0.01 & 0 & 0.13 \\
\hline Ex5-T & 0.23 & 0.04 & 0.11 & 0.13 & 0.21 & 0.07 & 0.06 & 0.06 & 0.04 & 0.05 & 0.05 \\
\hline Ex6-T & 0.1 & 0.14 & 0.12 & 0.12 & 0.12 & 0.09 & 0.07 & 0.08 & 0.08 & 0.1 & 0.02 \\
\hline Ex7-T & 0.15 & 0.1 & 0.1 & 0.1 & 0.14 & 0.13 & 0.12 & 0.06 & 0.06 & 0.05 & 0.03 \\
\hline Ex8-T & 0.07 & 0.03 & 0.11 & 0.26 & 0.28 & 0.06 & 0.07 & 0.07 & 0.03 & 0.01 & 0.11 \\
\hline Ex9-T & 0.2 & 0.06 & 0.2 & 0.19 & 0.25 & 0.03 & 0.03 & 0.02 & 0.01 & 0.01 & 0.13 \\
\hline Ex10-T & 0.1 & 0.1 & 0.1 & 0.1 & 0.1 & 0.1 & 0.1 & 0.1 & 0.1 & 0.1 & 0 \\
\hline Ex11-T & 0.25 & 0.02 & 0.07 & 0.16 & 0.32 & 0.07 & 0.03 & 0.05 & 0.01 & 0.02 & 0.1 \\
\hline Ex12-T & 0.16 & 0.1 & 0.11 & 0.15 & 0.13 & 0.08 & 0.04 & 0.05 & 0.05 & 0.12 & 0.02 \\
\hline Mean & 0.13 & 0.07 & 0.11 & 0.13 & 0.18 & 0.08 & 0.06 & 0.06 & 0.05 & 0.06 & \\
\hline Minimum & 0.07 & 0.02 & 0.07 & 0.1 & 0.1 & 0.03 & 0.03 & 0.02 & 0.01 & 0.01 & \\
\hline Maximum & 0.25 & 0.14 & 0.2 & 0.26 & 0.37 & 0.13 & 0.12 & 0.1 & 0.1 & 0.12 & \\
\hline $\begin{array}{l}\text { Standard } \\
\text { Deviation }\end{array}$ & 0.07 & 0.04 & 0.04 & 0.06 & 0.1 & 0.04 & 0.03 & 0.03 & 0.03 & 0.04 & \\
\hline Disagreement & & & & & & & & & & & 0.05 \\
\hline
\end{tabular}

\begin{tabular}{|l|c|c|c|c|}
\hline \multicolumn{5}{|c|}{ Technical Perspective } \\
\hline Source of Variation & $\begin{array}{c}\text { Sum of } \\
\text { Squares }\end{array}$ & $\begin{array}{c}\text { Degrees of } \\
\text { Freedom }\end{array}$ & Mean Square & $\begin{array}{c}\text { F-test } \\
\text { Value }\end{array}$ \\
\hline Between Criteria & 0.34 & 9 & .038 & 27.96 \\
\hline Between Experts & 0.09 & 12 & 0.008 & \\
\hline
\end{tabular}




\begin{tabular}{|l|c|c|c|c|}
\hline Residual & 0.15 & 108 & 0.001 & \\
\hline Total & 0.58 & 129 & & \\
\hline \multicolumn{2}{|l|}{ Critical F-value with degrees of freedom 9 \& 108 at 0.01 level: } & 2.58 \\
\hline Critical F-value with degrees of freedom 9 \& 108 at 0.025 level: & 2.23 \\
\hline Critical F-value with degrees of freedom 9 \& 108 at 0.05 level: & 1.97 \\
\hline \multicolumn{2}{|l|}{ Critical F-value with degrees of freedom 9 \& 108 at 0.1 level: } & 1.69 \\
\hline
\end{tabular}

\subsubsection{Ranking of Economic Perspective Criteria}

The economic perspective expert panel consisted of eleven experts. The experts evaluated the relative contribution of each criterion to the economic perspective using pairwise comparison constant-sum method as defined earlier. The arithmetic mean of the panel's evaluation is used to represent the relative ranking of the criteria. The resulting arithmetic mean of their evaluations and the levels of inconsistency and disagreement are shown in Table 27. The Return on Investment criterion was ranked the highest in terms of relative contribution to the economic perspective.

Table 27: Relative Ranking of Economic Criteria

\begin{tabular}{|c|c|c|c|c|c|c|c|c|c|c|c|}
\hline $\begin{array}{l}\text { Economic } \\
\text { Perspective } \\
\text { (E) }\end{array}$ & 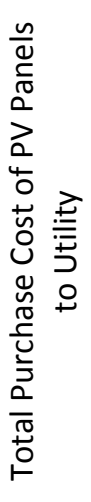 & 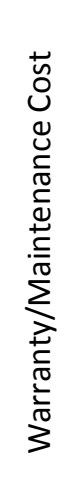 & 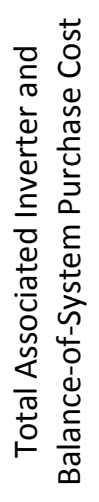 & 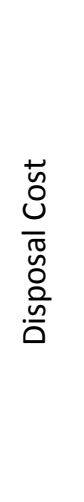 & 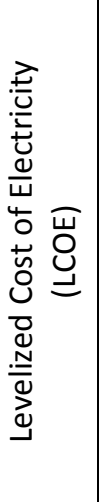 & 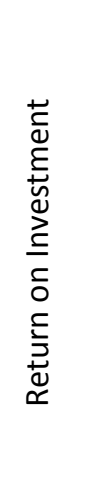 & 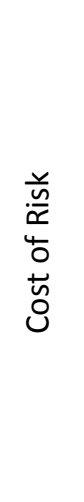 & 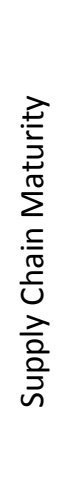 & 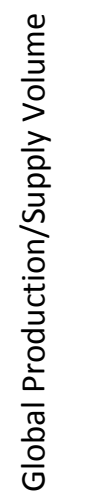 & 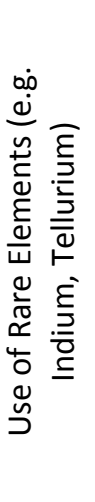 & 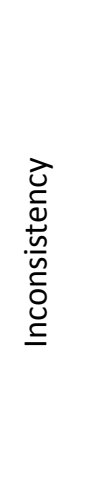 \\
\hline Ex1-E & 0.03 & 0.19 & 0.19 & 0.08 & 0.25 & 0.14 & 0.07 & 0.04 & 0.02 & 0.01 & 0.14 \\
\hline$E \times 2-E$ & 0.07 & 0.06 & 0.06 & 0.06 & 0.27 & 0.21 & 0.13 & 0.05 & 0.05 & 0.04 & 0.01 \\
\hline Ex3-E & 0.12 & 0.06 & 0.2 & 0.01 & 0.32 & 0.18 & 0.06 & 0.03 & 0.02 & 0.01 & 0.07 \\
\hline Ex4-E & 0.11 & 0.08 & 0.09 & 0.07 & 0.21 & 0.16 & 0.11 & 0.07 & 0.06 & 0.04 & 0.01 \\
\hline
\end{tabular}




\begin{tabular}{|c|c|c|c|c|c|c|c|c|c|c|c|}
\hline Ex5-E & 0.21 & 0.09 & 0.15 & 0.03 & 0.19 & 0.21 & 0.05 & 0.03 & 0.02 & 0.02 & 0.05 \\
\hline Ex6-E & 0.12 & 0.11 & 0.06 & 0.03 & 0.47 & 0.21 & 0.01 & 0 & 0 & 0 & 0.16 \\
\hline Ex7-E & 0.12 & 0.07 & 0.14 & 0.05 & 0.2 & 0.19 & 0.06 & 0.07 & 0.06 & 0.05 & 0 \\
\hline Ex8-E & 0.11 & 0.07 & 0.09 & 0.06 & 0.38 & 0.12 & 0.06 & 0.05 & 0.04 & 0.02 & 0.04 \\
\hline Ex9-E & 0.04 & 0.05 & 0.05 & 0.04 & 0.57 & 0.16 & 0.09 & 0 & 0 & 0 & 0.07 \\
\hline Ex10-E & 0.24 & 0.06 & 0.09 & 0.06 & 0.24 & 0.11 & 0.08 & 0.05 & 0.04 & 0.02 & 0.06 \\
\hline Ex11-E & 0.09 & 0.06 & 0.07 & 0.04 & 0.18 & 0.26 & 0.2 & 0.03 & 0.05 & 0.01 & 0.03 \\
\hline Mean & 0.11 & 0.08 & 0.11 & 0.05 & 0.3 & 0.18 & 0.08 & 0.04 & 0.03 & 0.02 & \\
\hline Minimum & 0.03 & 0.05 & 0.05 & 0.01 & 0.18 & 0.11 & 0.01 & 0.03 & 0.04 & 0.01 & \\
\hline Maximum & 0.24 & 0.19 & 0.2 & 0.08 & 0.57 & 0.26 & 0.2 & 0.07 & 0.06 & 0.05 & \\
\hline $\begin{array}{c}\text { Standard } \\
\text { Deviation }\end{array}$ & 0.06 & 0.04 & 0.05 & 0.02 & 0.12 & 0.04 & 0.05 & 0.02 & 0.02 & 0.02 & \\
\hline Disagreement & & & & & & & & & & & 0.04 \\
\hline
\end{tabular}

\begin{tabular}{|l|c|c|c|c|}
\hline \multicolumn{5}{|c|}{ Economic Perspective } \\
\hline Source of Variation & $\begin{array}{c}\text { Sum of } \\
\text { Squares }\end{array}$ & $\begin{array}{c}\text { Degrees of } \\
\text { Freedom }\end{array}$ & Mean Square & $\begin{array}{c}\text { F-test } \\
\text { Value }\end{array}$ \\
\hline Between Criteria & 0.70 & 9 & .078 & 22.8 \\
\hline Between Experts & 0.00 & 10 & 0.000 & \\
\hline Residual & 0.31 & 90 & 0.003 & \\
\hline Total & 1.01 & 109 & & 2.61 \\
\hline Critical F-value with degrees of freedom 9 \& 90 at 0.01 level: & 2.26 \\
\hline Critical F-value with degrees of freedom 9 \& 90 at 0.025 level: & 1.99 \\
\hline Critical F-value with degrees of freedom 9 \& 90 at 0.05 level: & 1.7 \\
\hline \multicolumn{7}{|l}{ Critical F-value with degrees of freedom 9 \& 90 at 0.1 level: } \\
\hline
\end{tabular}

\subsubsection{Ranking of Environmental Perspective Criteria}

The environmental perspective expert panel consisted of eleven experts. The experts evaluated the relative contribution of each criterion to the environmental perspective using pairwise comparison constant-sum method as defined earlier. The arithmetic 
mean of the panel's evaluation is used to represent the relative ranking of the criteria.

The resulting arithmetic mean of their evaluations and the levels of inconsistency and disagreement are shown Table 28. The Use of Hazardous Materials criterion was ranked the highest in terms of relative contribution to the environmental perspective.

\begin{tabular}{|c|c|c|c|c|c|c|c|c|c|c|}
\hline $\begin{array}{l}\text { Environmental } \\
\text { Perspective } \\
\text { (En) }\end{array}$ & 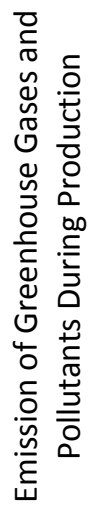 & 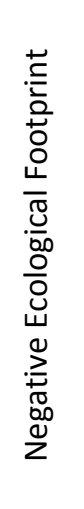 & 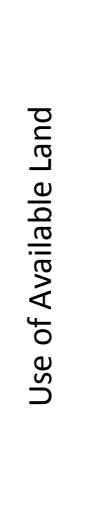 & 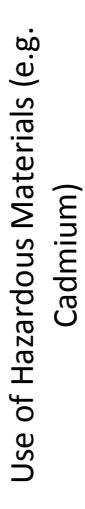 & 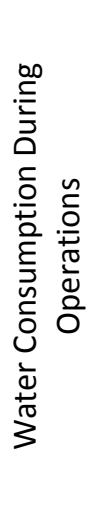 & 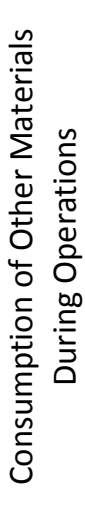 & 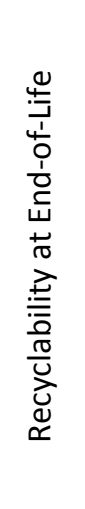 & 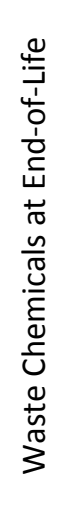 & 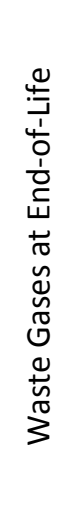 & 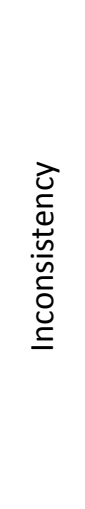 \\
\hline Ex1-N & 0.07 & 0.07 & 0.15 & 0.13 & 0.13 & 0.13 & 0.11 & 0.12 & 0.1 & 0.01 \\
\hline Ex2-N & 0.14 & 0.14 & 0.13 & 0.1 & 0.09 & 0.1 & 0.14 & 0.09 & 0.08 & 0.02 \\
\hline Ex3-N & 0.1 & 0.14 & 0.24 & 0.21 & 0.06 & 0.05 & 0.07 & 0.08 & 0.05 & 0.04 \\
\hline Ex4-N & 0.11 & 0.13 & 0.07 & 0.19 & 0.08 & 0.07 & 0.13 & 0.1 & 0.12 & 0.01 \\
\hline Ex5-N & 0.09 & 0.11 & 0.04 & 0.22 & 0.32 & 0.09 & 0.04 & 0.04 & 0.04 & 0.03 \\
\hline Ex6-N & 0.21 & 0.12 & 0.14 & 0.25 & 0.21 & 0.05 & 0.01 & 0 & 0 & 0.13 \\
\hline Ex7-N & 0.16 & 0.17 & 0.16 & 0.1 & 0.07 & 0.08 & 0.09 & 0.09 & 0.08 & 0.01 \\
\hline Ex8-N & 0.19 & 0.16 & 0.07 & 0.14 & 0.08 & 0.08 & 0.13 & 0.09 & 0.06 & 0.02 \\
\hline Ex9-N & 0.18 & 0.08 & 0.01 & 0.67 & 0.01 & 0.01 & 0.02 & 0.02 & 0 & 0.12 \\
\hline Ex10-N & 0.14 & 0.22 & 0.15 & 0.18 & 0.12 & 0.1 & 0.04 & 0.03 & 0.02 & 0.1 \\
\hline Mean & 0.14 & 0.13 & 0.12 & 0.22 & 0.12 & 0.08 & 0.08 & 0.07 & 0.06 & \\
\hline Minimum & 0.07 & 0.07 & 0.01 & 0.1 & 0.01 & 0.01 & 0.01 & 0.02 & 0.02 & \\
\hline Maximum & 0.21 & 0.22 & 0.24 & 0.67 & 0.32 & 0.13 & 0.14 & 0.12 & 0.12 & \\
\hline $\begin{array}{l}\text { Standard } \\
\text { Deviation }\end{array}$ & 0.04 & 0.04 & 0.06 & 0.16 & 0.08 & 0.03 & 0.05 & 0.04 & 0.04 & \\
\hline Disagreement & & & & & & & & & & 0.06 \\
\hline
\end{tabular}




\begin{tabular}{|l|c|c|c|c|}
\hline \multicolumn{5}{|c|}{ Environmental Perspective } \\
\hline Source of Variation & $\begin{array}{c}\text { Sum of } \\
\text { Squares }\end{array}$ & $\begin{array}{c}\text { Degrees of } \\
\text { Freedom }\end{array}$ & Mean Square & $\begin{array}{c}\text { F-test } \\
\text { Value }\end{array}$ \\
\hline Between Criteria & 0.21 & 8 & .026 & 4.03 \\
\hline Between Experts & 0.00 & 9 & 0.000 & \\
\hline Residual & 0.46 & 72 & 0.003 & \\
\hline Total & 0.66 & 89 & & 2.77 \\
\hline Critical F-value with degrees of freedom 8 \& 72 at 0.01 level: & 2.37 \\
\hline Critical F-value with degrees of freedom 8 \& 72 at 0.025 level: & 2.07 \\
\hline Critical F-value with degrees of freedom 8 \& 72 at 0.05 level: & 2.07 \\
\hline Critical F-value with degrees of freedom 8 \& 72 at 0.1 level: & 1.76 \\
\hline
\end{tabular}

\subsubsection{Ranking of Political Perspective Criteria}

The political perspective expert panel consisted of nine experts. The experts evaluated the relative contribution of each criterion to the political perspective using pairwise comparison constant-sum method as defined earlier. The arithmetic mean of the panel's evaluation is used to represent the relative ranking of the criteria. The resulting arithmetic mean of their evaluations and the levels of inconsistency and disagreement are shown in Table 29. The Government Incentives criterion was ranked the highest in terms of relative contribution to the political perspective. 
Table 29: Relative Ranking of Political Criteria

\begin{tabular}{|c|c|c|c|c|c|c|c|}
\hline $\begin{array}{c}\text { Political } \\
\text { Perspective } \\
\text { (P) }\end{array}$ & 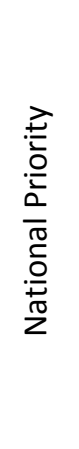 & 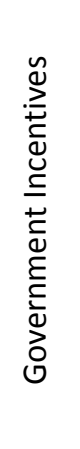 & 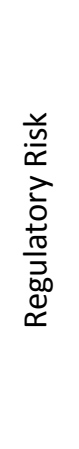 & 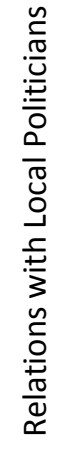 & 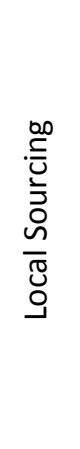 & 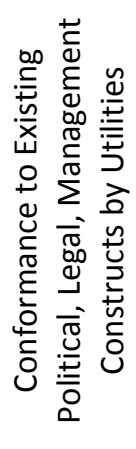 & 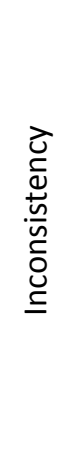 \\
\hline Ex1-P & 0.11 & 0.2 & 0.28 & 0.1 & 0.15 & 0.16 & 0.04 \\
\hline Ex2-P & 0.09 & 0.11 & 0.41 & 0.15 & 0.11 & 0.13 & 0.01 \\
\hline Ex3-P & 0.04 & 0.55 & 0.05 & 0.1 & 0.17 & 0.09 & 0.03 \\
\hline Ex4-P & 0.16 & 0.33 & 0.09 & 0.09 & 0.06 & 0.26 & 0.08 \\
\hline Ex5-P & 0.04 & 0.26 & 0.33 & 0.24 & 0.03 & 0.09 & 0.12 \\
\hline Ex6-P & 0.07 & 0.21 & 0.33 & 0.08 & 0.13 & 0.19 & 0.01 \\
\hline Ex7-P & 0.11 & 0.17 & 0.34 & 0.13 & 0.15 & 0.1 & 0.06 \\
\hline Ex8-P & 0.08 & 0.36 & 0.17 & 0.06 & 0.23 & 0.09 & 0.13 \\
\hline Ex9-P & 0.08 & 0.31 & 0.09 & 0.17 & 0.13 & 0.22 & 0.03 \\
\hline Mean & 0.09 & 0.28 & 0.23 & 0.12 & 0.13 & 0.15 & \\
\hline Minimum & 0.04 & 0.11 & 0.05 & 0.06 & 0.03 & 0.09 & \\
\hline Maximum & 0.16 & 0.55 & 0.41 & 0.24 & 0.23 & 0.26 & \\
\hline $\begin{array}{l}\text { Standard } \\
\text { Deviation }\end{array}$ & 0.04 & 0.12 & 0.13 & 0.05 & 0.06 & 0.06 & \\
\hline Disagreement & & & & & & & 0.08 \\
\hline
\end{tabular}

\begin{tabular}{|l|c|c|c|c|}
\hline \multicolumn{5}{|c|}{ Political Perspective } \\
\hline Source of Variation & $\begin{array}{c}\text { Sum of } \\
\text { Squares }\end{array}$ & $\begin{array}{c}\text { Degrees of } \\
\text { Freedom }\end{array}$ & Mean Square & $\begin{array}{c}\text { F-test } \\
\text { Value }\end{array}$ \\
\hline Between Criteria & 0.24 & 5 & .048 & 5.14 \\
\hline Between Experts & 0.00 & 8 & 0.000 & \\
\hline Residual & 0.37 & 40 & 0.009 & \\
\hline Total & 0.61 & 53 & & 3.51 \\
\hline Critical F-value with degrees of freedom 5 \& 40 at 0.01 level: & \\
\hline
\end{tabular}




\begin{tabular}{|l|c|}
\hline Critical F-value with degrees of freedom $5 \& 40$ at 0.025 level: & 2.9 \\
\hline Critical F-value with degrees of freedom $5 \& 40$ at 0.05 level: & 2.45 \\
\hline Critical F-value with degrees of freedom $5 \& 40$ at 0.1 level: & 2.0 \\
\hline
\end{tabular}

\subsubsection{STEEP Desirability Functions}

The desirability functions are used to represent the mapping of technological characteristics or metrics to a desirability value in the range of 0 to $100-$ with 100 being most desirable and 0 being unacceptable. The desirability functions are discussed in Chapter 4. The desirability values of metrics for the criteria can be graphically shown as desirability curves. The metrics are arranged on the horizontal axis and the corresponding desirability values on the vertical axis. The direct plotting on grid method was used to construct the desirability functions and the research instrument is provided in Appendix D. The experts provided their judgment for the desirability values corresponding to a criterion measure. The arithmetic mean of each desirability value was taken to represent the corresponding criterion measure. The desirability functions for all STEEP perspective criteria are shown as charts in Figure 30, Figure 31, Figure 32, Figure 33, and Figure 34. 
SOCIAL
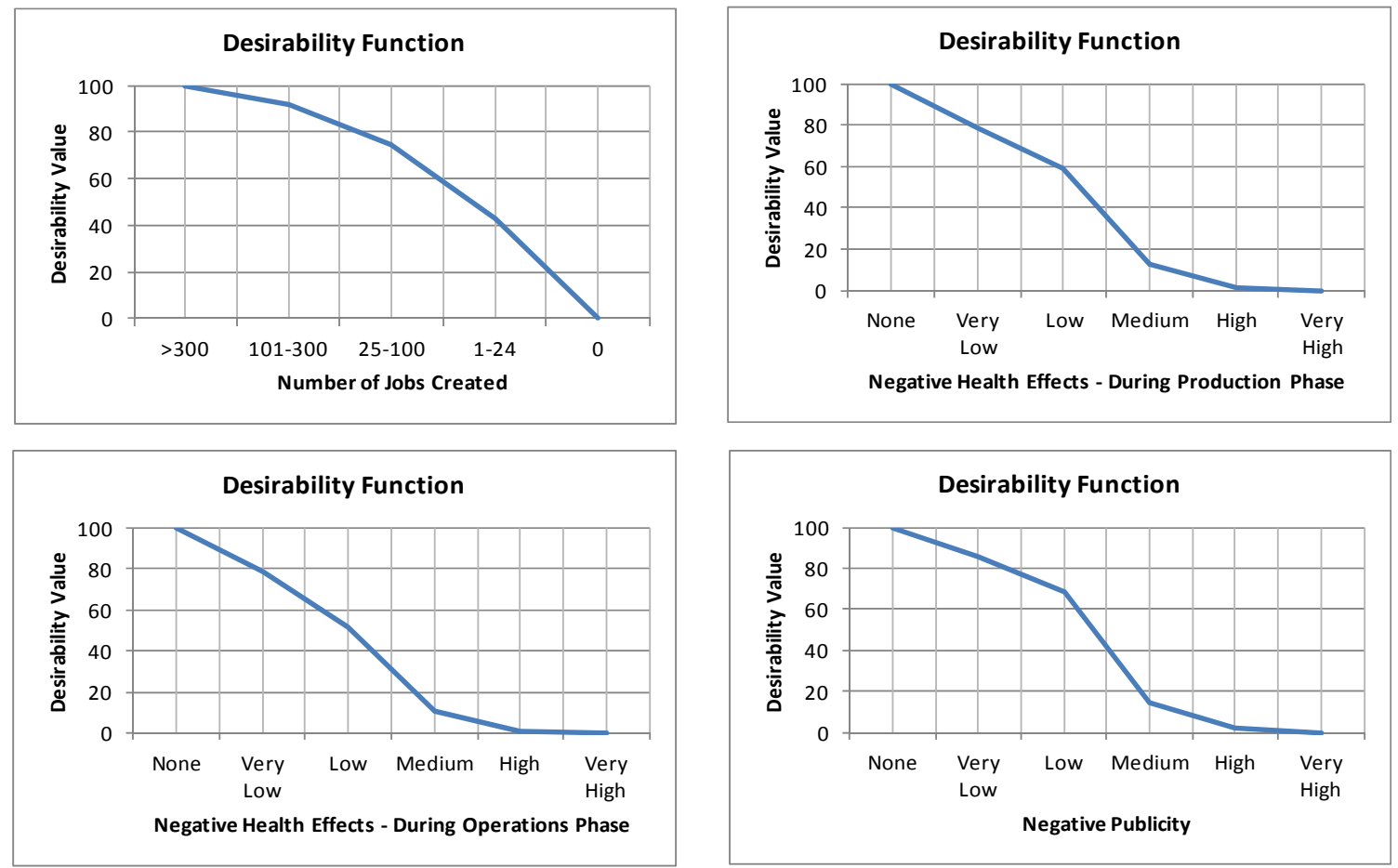

Figure 30: Desirability Functions for Social Criteria 


\section{TECHNICAL}
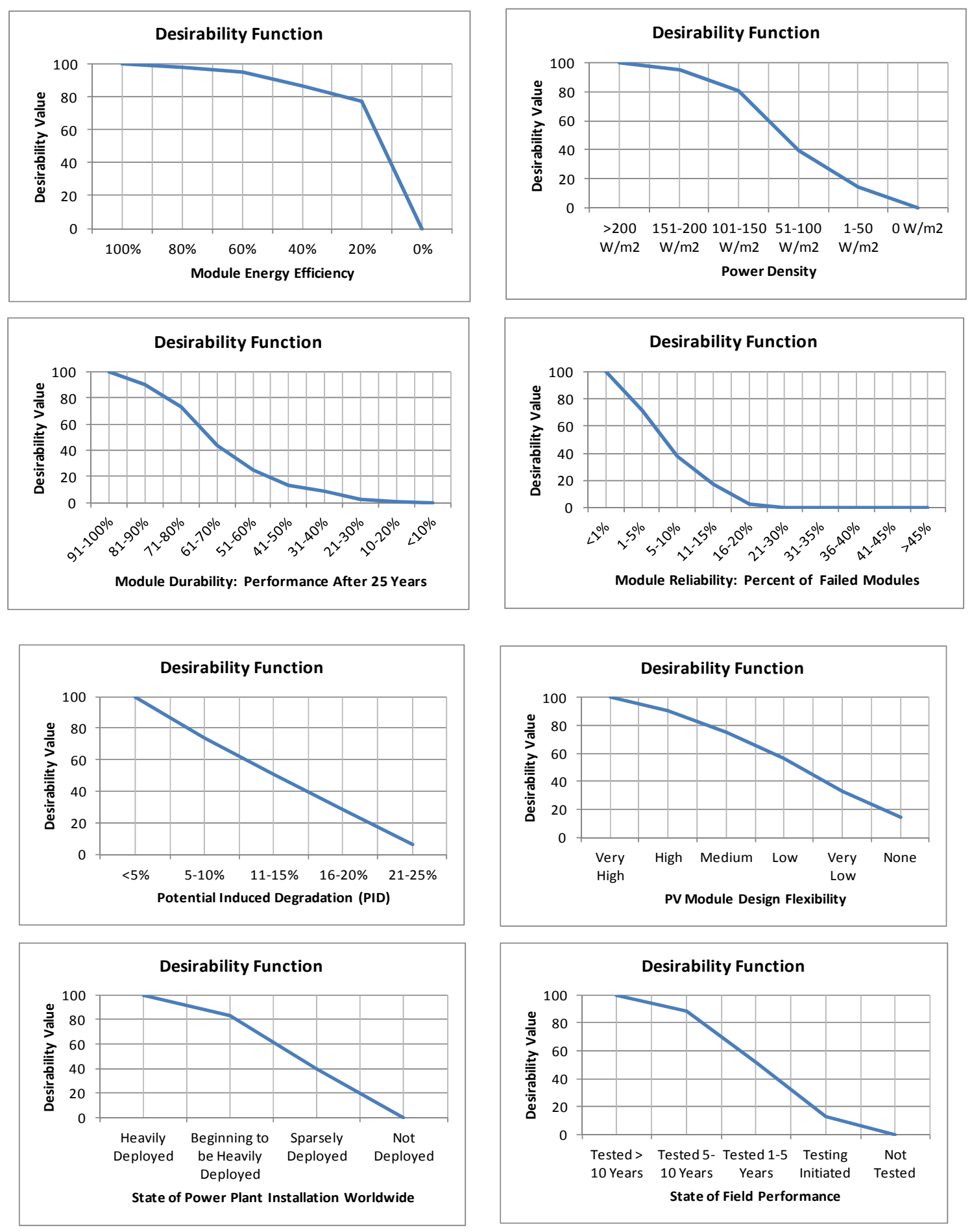

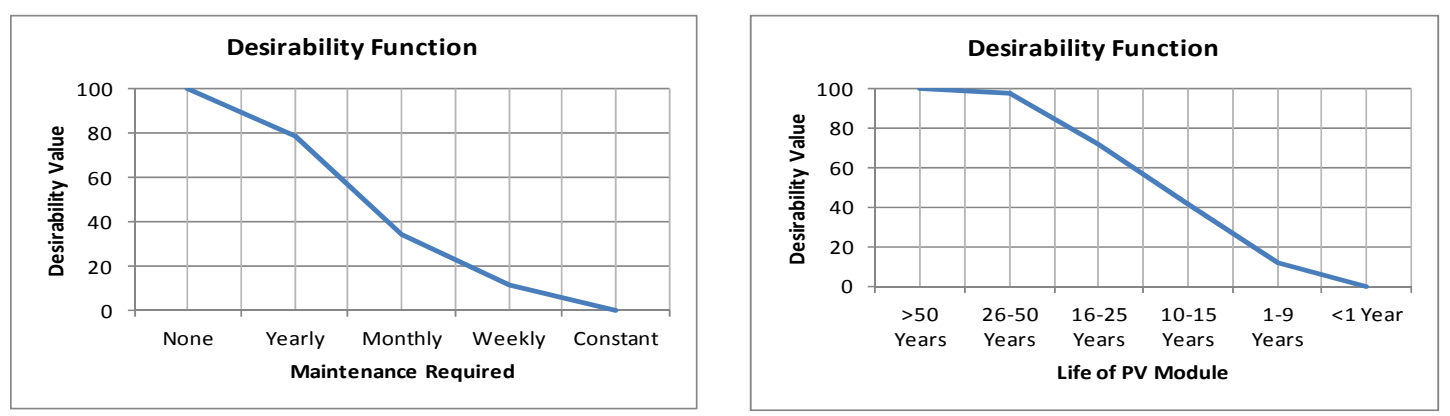

Figure 31: Desirability Functions for Technical Criteria 


\section{ECONOMIC}
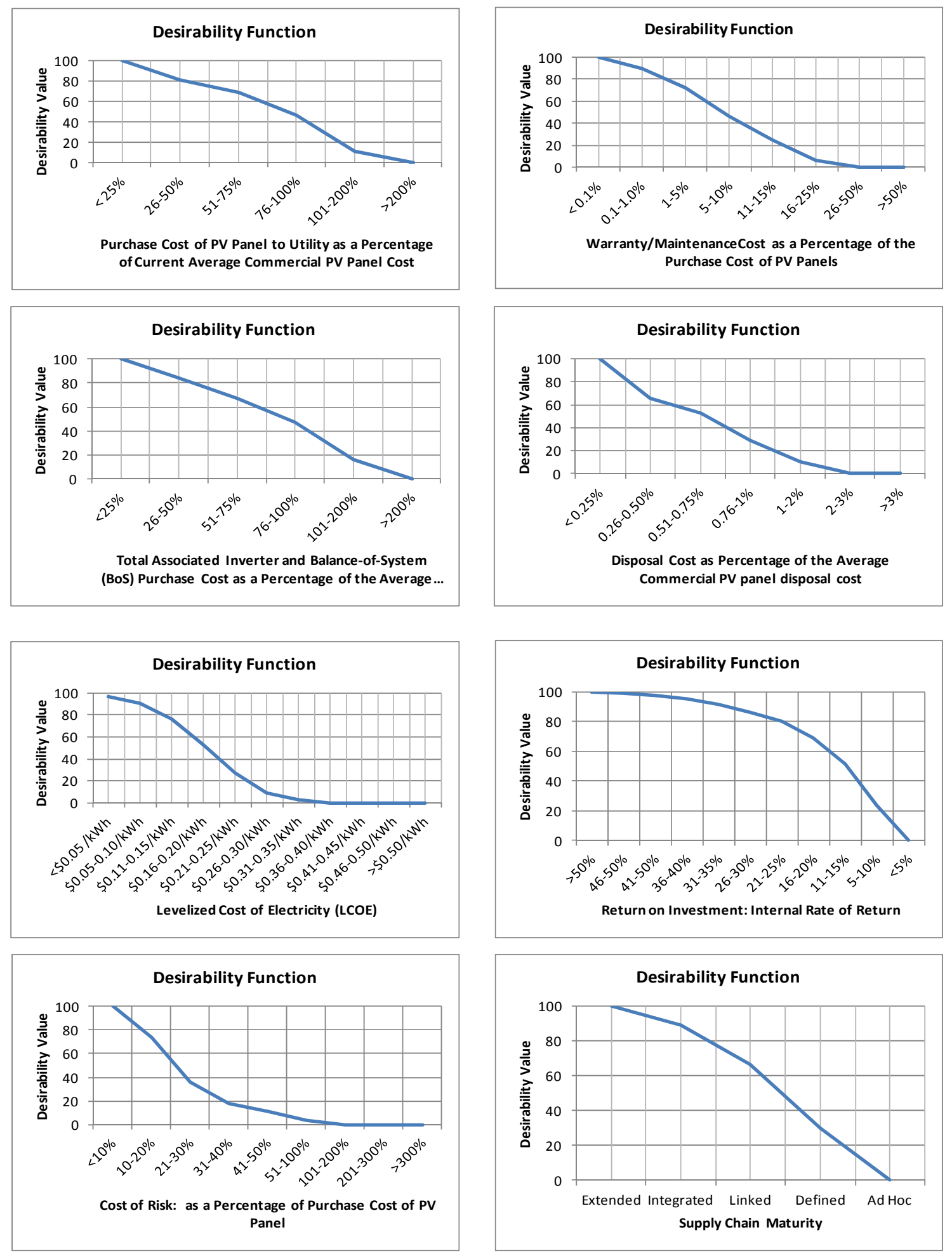

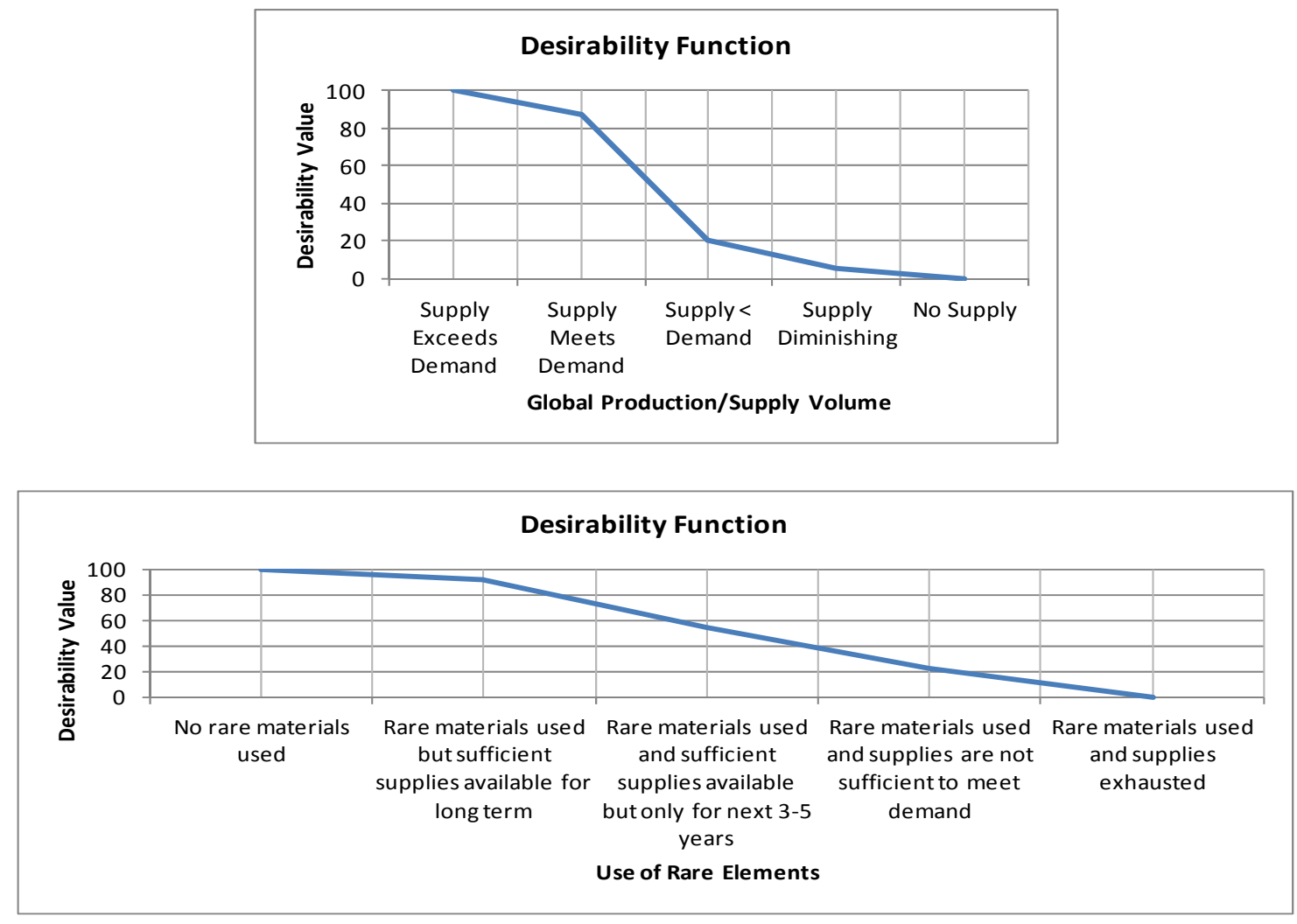

Figure 32: Desirability Functions for Economic Criteria

\section{ENVIRONMENTAL}
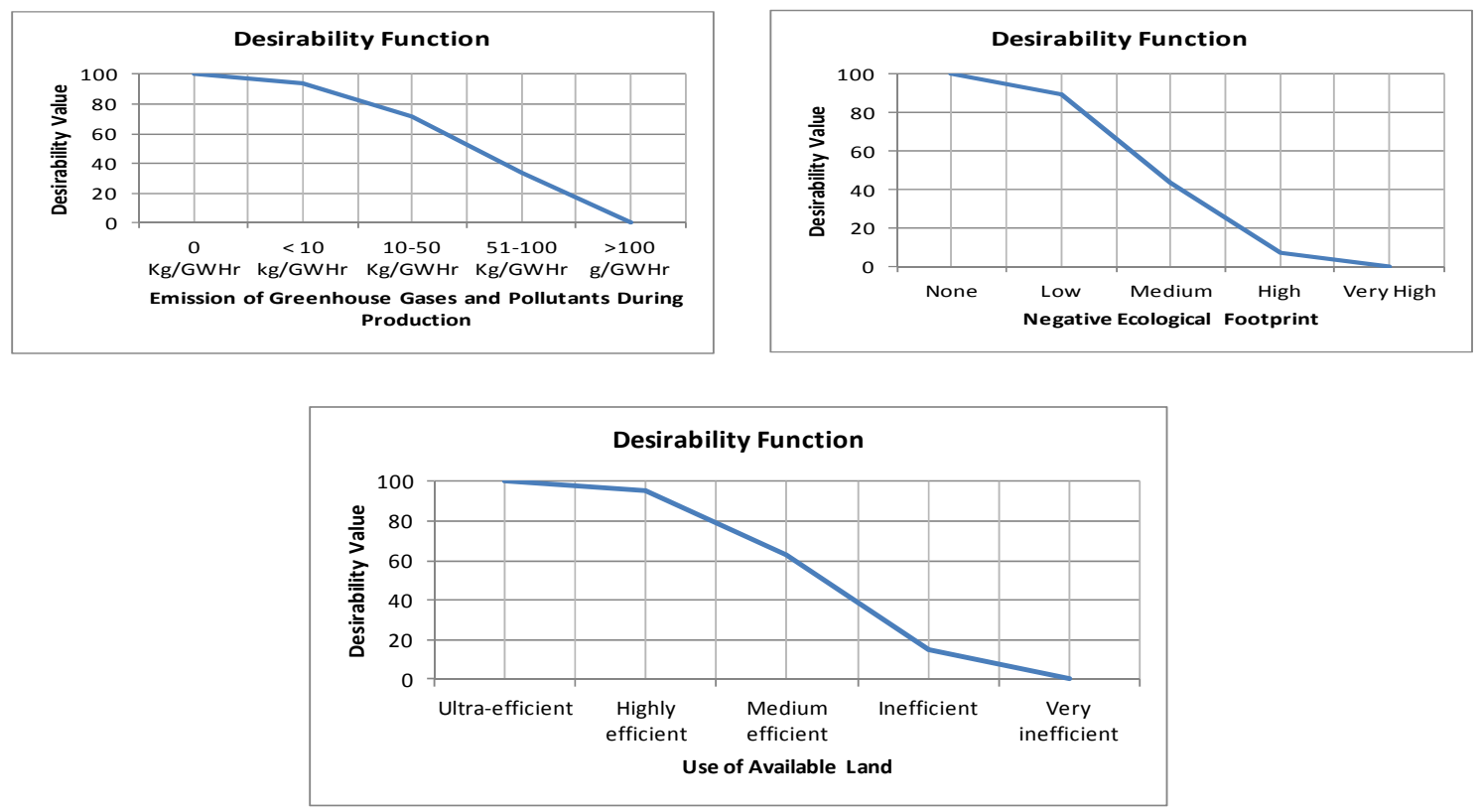

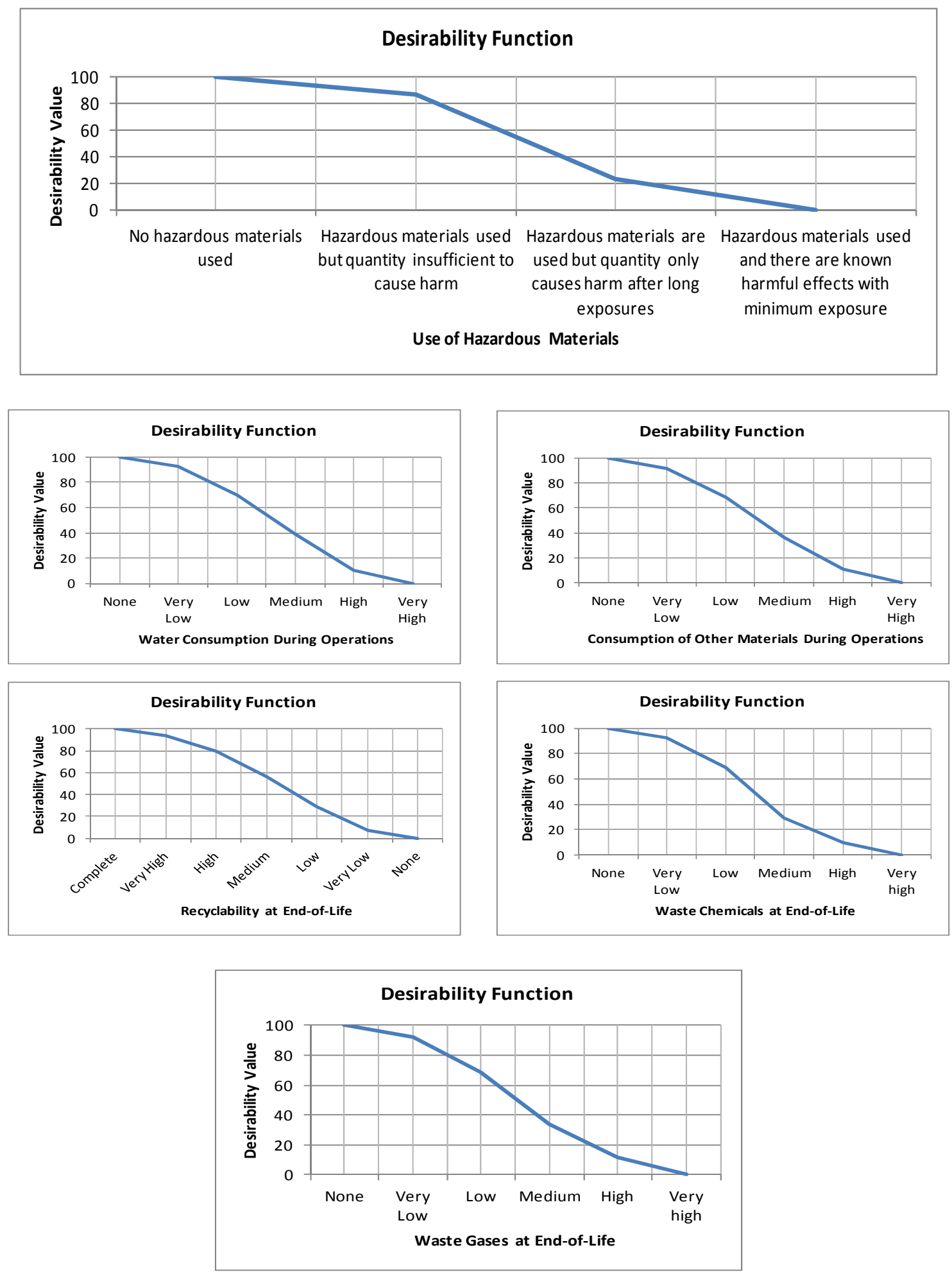

Figure 33: Desirability Functions for Environmental Criteria 


\section{POLITICAL}
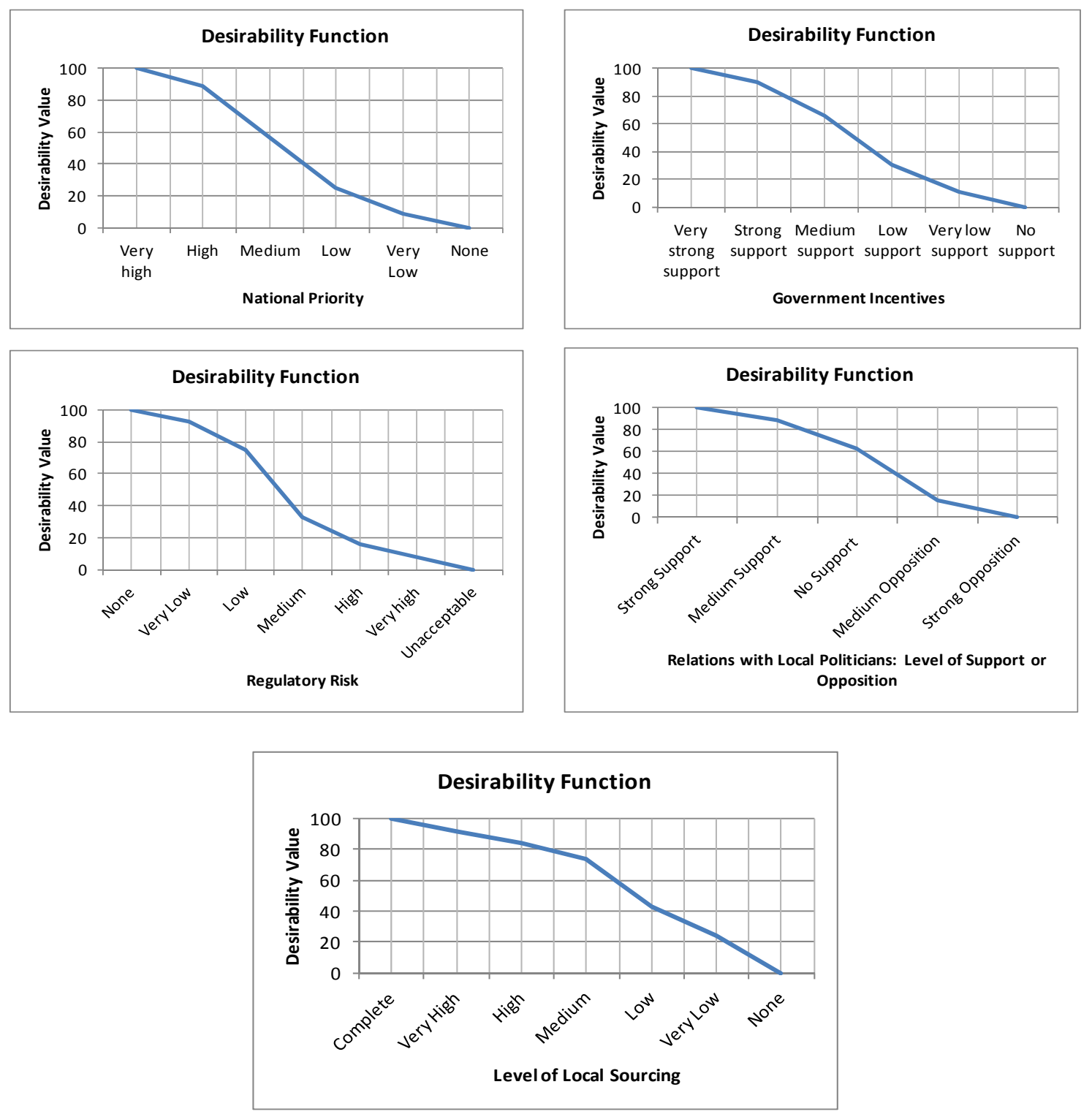


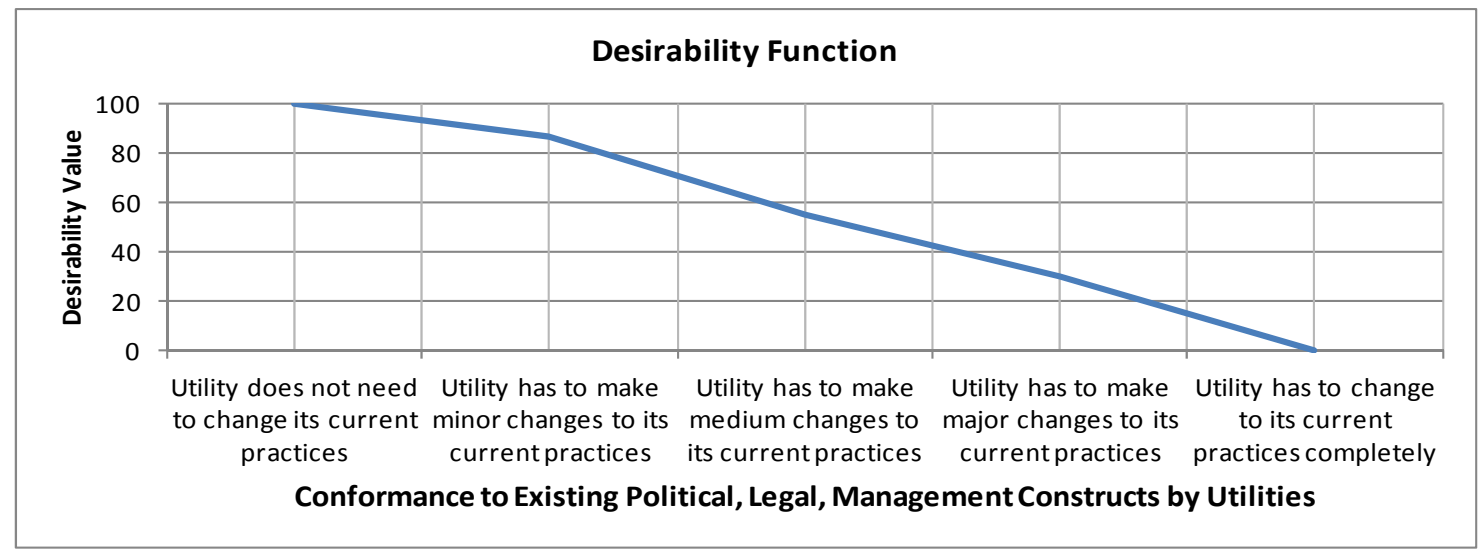

Figure 34: Desirability Functions for Political Criteria

\subsubsection{STEEP Desirability Values of Candidate PV Technologies}

A group meeting with three experts was the forum to decide the desirability values for the five candidate PV technologies. The values were based on a unanimous consensus. The results are shown in tables: Table 30, Table 31, Table 32, Table 33, and Table 34. In the social perspective, all five PV technologies had similar values except for the job creation criterion which strongly favored the silicone-based PV technologies c-Si and aSi. This is mainly because these were more prevalent, installations were more labor intensive, and training was readily available for these mature technologies.

Table 30: Desirability Values of Candidate PV Technologies: Social Criteria

\begin{tabular}{|c|c|c|c|c|}
\hline $\begin{array}{c}\text { Social } \\
\text { Perspective }\end{array}$ & 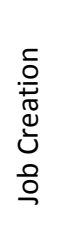 & 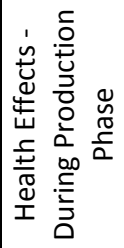 & 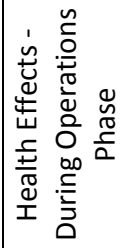 & 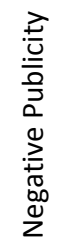 \\
\hline$c-S i$ & 75 & 95 & 100 & 90 \\
\hline $\mathrm{a}-\mathrm{Si}$ & 75 & 95 & 100 & 90 \\
\hline
\end{tabular}




\begin{tabular}{|c|c|c|c|c|}
\hline CIGS & 43 & 95 & 98 & 90 \\
\hline CdTe & 43 & 95 & 98 & 90 \\
\hline OPV & 43 & 95 & 98 & 90 \\
\hline
\end{tabular}

Table 31: Desirability Values of Candidate PV Technologies: Technical Criteria

\begin{tabular}{|c|c|c|c|c|c|c|c|c|c|c|}
\hline $\begin{array}{l}\text { Technical } \\
\text { Perspective }\end{array}$ & 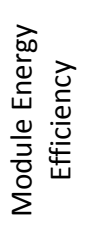 & 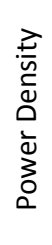 & 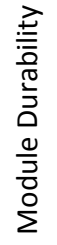 & 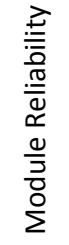 & 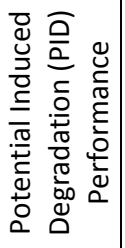 & 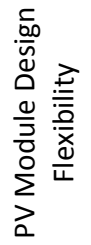 & 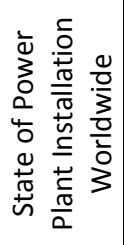 & 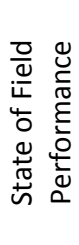 & 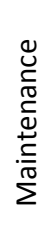 & 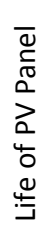 \\
\hline c-Si & 78 & 95 & 90 & 100 & 100 & 91 & 100 & 100 & 78 & 72 \\
\hline $\mathrm{a}-\mathrm{Si}$ & 66 & 95 & 90 & 100 & 100 & 91 & 100 & 100 & 78 & 72 \\
\hline CIGS & 43 & 81 & 25 & 100 & 100 & 100 & 83 & 100 & 78 & 42 \\
\hline CdTe & 43 & 81 & 25 & 100 & 100 & 100 & 83 & 100 & 78 & 42 \\
\hline OPV & 10 & 39 & 17 & 17 & 51 & 100 & 0 & 12 & 78 & 12 \\
\hline
\end{tabular}

Table 32: Desirability Values of Candidate PV Technologies: Economic Criteria

\begin{tabular}{|c|c|c|c|c|c|c|c|c|c|c|}
\hline $\begin{array}{l}\text { Economic } \\
\text { Perspective }\end{array}$ & 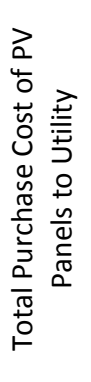 & 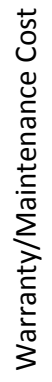 & 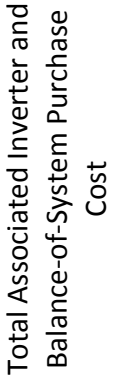 & 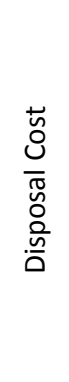 & 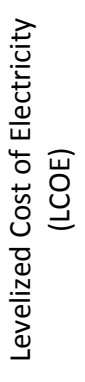 & 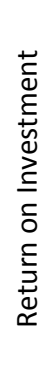 & 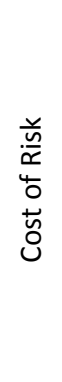 & 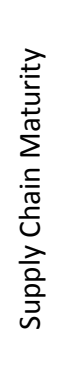 & 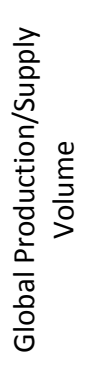 & 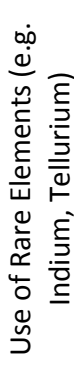 \\
\hline$c-S i$ & 46 & 90 & 48 & 65 & 76 & 51 & 100 & 100 & 100 & 100 \\
\hline a-Si & 46 & 90 & 48 & 65 & 76 & 51 & 74 & 100 & 100 & 100 \\
\hline CIGS & 46 & 90 & 48 & 65 & 76 & 51 & 74 & 66 & 100 & 91 \\
\hline CdTe & 46 & 90 & 48 & 65 & 76 & 51 & 74 & 66 & 100 & 100 \\
\hline OPV & 46 & 90 & 16 & 100 & 76 & 0 & 36 & 0 & 0 & 100 \\
\hline
\end{tabular}


Table 33: Desirability Values of Candidate PV Technologies: Environmental Criteria

\begin{tabular}{|c|c|c|c|c|c|c|c|c|c|}
\hline $\begin{array}{l}\text { Environmental } \\
\text { Perspective }\end{array}$ & 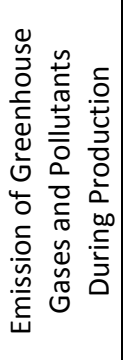 & 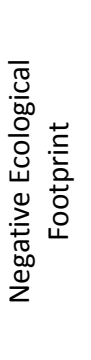 & 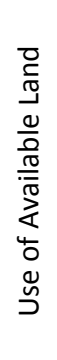 & 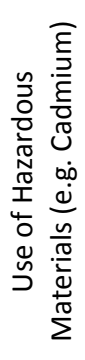 & 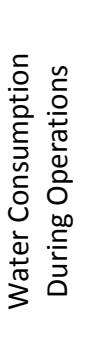 & 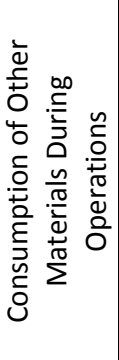 & 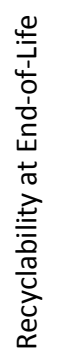 & 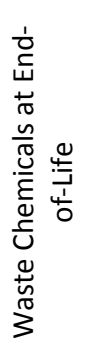 & 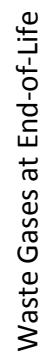 \\
\hline$c-S i$ & 71 & 89 & 95 & 86 & 93 & 91 & 80 & 93 & 93 \\
\hline $\mathrm{a}-\mathrm{Si}$ & 71 & 89 & 95 & 86 & 93 & 91 & 80 & 93 & 93 \\
\hline CIGS & 71 & 89 & 63 & 86 & 93 & 91 & 80 & 93 & 93 \\
\hline CdTe & 71 & 89 & 63 & 86 & 93 & 91 & 80 & 93 & 93 \\
\hline OPV & 94 & 89 & 63 & 100 & 93 & 91 & 94 & 93 & 93 \\
\hline
\end{tabular}

Table 34: Desirability Values of Candidate PV Technologies: Political Criteria

\begin{tabular}{|c|c|c|c|c|c|c|}
\hline $\begin{array}{c}\text { Political } \\
\text { Perspective }\end{array}$ & 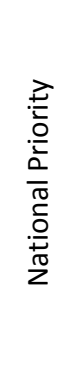 & 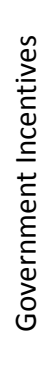 & 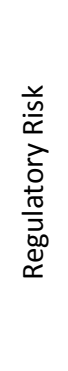 & 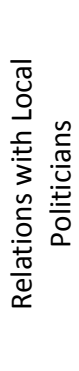 & 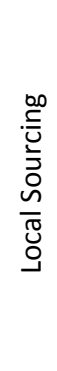 & 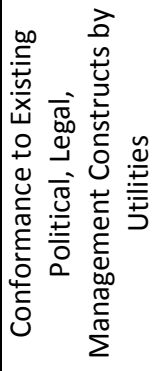 \\
\hline $\mathrm{c}-\mathrm{Si}$ & 100 & 90 & 100 & 100 & 100 & 86 \\
\hline $\mathrm{a}-\mathrm{Si}$ & 100 & 90 & 100 & 100 & 100 & 86 \\
\hline CIGS & 100 & 90 & 100 & 100 & 100 & 86 \\
\hline CdTe & 100 & 90 & 100 & 100 & 43 & 86 \\
\hline OPV & 100 & 90 & 100 & 100 & 24 & 86 \\
\hline
\end{tabular}

\subsubsection{Calculated Technology Values of Candidate PV Technologies}

The theoretical background for the technology value (TV) calculations is described in Section 4.6 and main formula for the nth technology is presented below.

$$
T V_{n}=\sum_{k=1}^{K} \sum_{j_{k}=1}^{J_{k}} p_{k} \cdot c_{j_{k}, k} \cdot V\left(t_{n, j_{k}, k}\right)
$$


The calculated values for the five candidate PV technologies $(n=1,2,3,4,5)$ are shown and compared in Table 35, Table 36, and Figure 35. The sub-totals are shown for each STEEP perspective followed by the cumulative technology value totals for the PV technology values. Hence, quantitatively, it is clear that the best or most highly ranked technology is c-Si with a Technology Value equal to 82 followed closely by a-Si with a Technology Value of 81 . These two form a cluster and may be considered as one group consisting of silicon PV technologies. The second group consists of the popular PV thin-films CIGS and CdTe with Technology Values of 75 and 74 respectively. Plastic or organic PV (OPV) belongs to a third group with a Technology Value of 61 . These three groups also represent three separate generations of PV technologies.

Table 35: Technology Values for Five Candidate Technologies: c-Si, a-Si, CIGS, CdTe, and OPV

\begin{tabular}{|c|c|c|c|c|c|c|}
\hline $\begin{array}{c}\text { PV } \\
\text { Technology }\end{array}$ & $\begin{array}{c}\text { Social } \\
\text { Perspective } \\
(\mathrm{S})\end{array}$ & $\begin{array}{c}\text { Technical } \\
\text { Perspective } \\
(\mathrm{T})\end{array}$ & $\begin{array}{c}\text { Economic } \\
\text { Perspective } \\
(\mathrm{E})\end{array}$ & $\begin{array}{c}\text { Environmental } \\
\text { Perspective (N) }\end{array}$ & $\begin{array}{c}\text { Political } \\
\text { Perspective } \\
(\mathrm{P})\end{array}$ & $\begin{array}{c}\text { Technology } \\
\text { Value (TV) } \\
(\mathrm{S}+\mathrm{T}+\mathrm{E}+\mathrm{N}+\mathrm{P})\end{array}$ \\
\hline $\mathrm{C}-\mathrm{Si}$ & 12 & 20 & 24 & 17 & 10 & 82 \\
\hline a-Si & 12 & 19 & 23 & 17 & 10 & 81 \\
\hline CIGS & 11 & 16 & 22 & 16 & 10 & 75 \\
\hline CdTe & 11 & 16 & 23 & 16 & 9 & 74 \\
\hline OPV & 11 & 7 & 16 & 18 & 9 & 60 \\
\hline
\end{tabular}

Table 36: Technology Value Comparison with Respect to the Best Technology

\begin{tabular}{|c|c|c|}
\hline $\begin{array}{c}\text { PV } \\
\text { Technology }\end{array}$ & $\begin{array}{c}\text { Technology } \\
\text { Value }\end{array}$ & $\begin{array}{c}\text { Comparison } \\
\text { to Best } \\
\text { Technology }\end{array}$ \\
\hline $\mathrm{c}-\mathrm{Si}$ & 82 & $100 \%$ \\
\hline $\mathrm{a}-\mathrm{Si}$ & 81 & $99 \%$ \\
\hline $\mathrm{CIGS}$ & 75 & $92 \%$ \\
\hline CdTe & 74 & $91 \%$ \\
\hline OPV & 60 & $73 \%$ \\
\hline
\end{tabular}




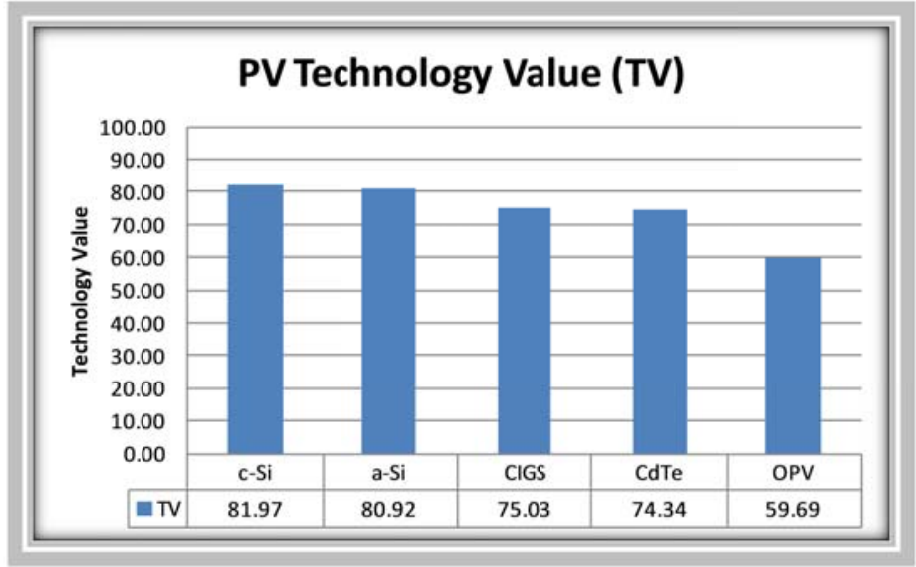

Figure 35: Technology Values for Five Candidate Technologies: c-Si, a-Si, CIGS, CdTe, and OPV

\subsubsection{Improvements Needed to Make OPV Top Ranked Technology}

OPV was the lowest ranked technology. Recommendations can be made to improve different performance characteristics of OPV to enable its ranking to improve. The following Table 37 shows that if the OPV technology characteristics can be changed from their current values to the listed improved values, then OPV become the top ranked candidate PV technology. Only the criteria list in this table need to be considered since OPV already has the same or better desirability values compared to cSi for the other criteria.

Table 37: Improvements Needed for OPV to be Top Ranked

\begin{tabular}{|c|c|c|c|}
\hline \multirow{2}{*}{\multicolumn{2}{|c|}{ Criterion }} & \multicolumn{2}{|c|}{ OPV Performance Metric Value* } \\
\hline & & \multirow{2}{*}{$\begin{array}{l}\text { Current } \\
1-24\end{array}$} & \multirow{2}{*}{ Improved } \\
\hline S1 & Job Creation & & \\
\hline $\mathrm{T} 1$ & Module Energy Efficiency & $3 \%$ & $20 \%$ \\
\hline $\mathrm{T} 2$ & Power Density & $51-100 \mathrm{~W} / \mathrm{m} 2$ & $151-200 \mathrm{~W} / \mathrm{m} 2$ \\
\hline
\end{tabular}




\begin{tabular}{|l|l|l|l|}
\hline T3 & Module Durability & $10-20 \%$ & $81-90 \%$ \\
\hline T4 & Module Reliability (Failure Rate) & $11-15 \%$ & $<1 \%$ \\
\hline T5 & $\begin{array}{l}\text { Potential Induced Degradation (PID) } \\
\text { Performance }\end{array}$ & $11-15 \%$ & $<5 \%$ \\
\hline T7 & State of Power Plant Installation Worldwide & Not Deployed & Heavily Deployed \\
\hline T8 & State of Field Performance & Testing Initiated & Tested $>10$ Years \\
\hline T10 & Life of PV Panel & $1-9$ Years & $16-25$ Years \\
\hline E1 & Total Purchase Cost of PV Panels to Utility & $76-100 \%$ & $26-50 \%$ \\
\hline E3 & $\begin{array}{l}\text { Total Associated Inverter and Balance-of- } \\
\text { System Purchase Cost }\end{array}$ & $101-200 \%$ & $76-100 \%$ \\
\hline E6 & Return on Investment & $<5 \%$ & $11-15 \%$ \\
\hline E7 & Cost of Risk & $21-30 \%$ & $<10 \%$ \\
\hline E8 & Supply Chain Maturity & Ad Hoc & Extended \\
\hline E9 & Global Production/Supply Volume & No Supply & $\begin{array}{l}\text { Supply Exceeds } \\
\text { Demand }\end{array}$ \\
\hline P5 & Local Sourcing & Very Low & Complete \\
\hline
\end{tabular}

\subsubsection{Result Validation and Analysis}

\subsubsection{Content, Construct, and Criterion-related Validity}

Research and data validation is described in Chapter 4 and this section summarizes the salient aspects of the data and results validation.

Content was validated at each step of modeling and developing the research instruments with the experts providing their feedback. For the HDM criteria selection and validation a two-thirds majority consensus process was used. 
Criterion-related validity was applied to the comparative judgment quantification using the expert inconsistency and disagreement among experts as the statistical measures. The inconsistency value represents the quality of relative rank or weight of the criterion [98], [99]. For $\mathrm{n}$ elements that are being compared in pairs there are $\mathrm{n}$ factorial ( $n$ !) orientations. If there is no inconsistency in the judgments expressed by an expert in providing pairwise comparisons for the elements, the relative values of the elements remain unchanged for all the orientations. Judgment inconsistency translates to different relative values in different orientations. The web-based pairwise comparison and inconsistency measure calculation software has been developed by our Engineering and Technology Management Department. This software was used as a research instrument and for calculating the inconsistency and disagreement measures.

The recommended value of inconsistency is typically between 0.0 and 0.10 . Occasionally, the inconsistency measure was more than 0.10 for an expert; for example it was 0.15 . The expert judgment was still included in the results because the criteria that were compared were typically not hard and quantitative but more soft and qualitative. For example, the experts were asked to compare the social criteria "Health Effects - During Production Phase", "Health Effects - During Operations Phase" "Negative Publicity" as pairwise comparisons. 
Disagreement measures between experts are also indicated in the results for each STEEP criterion. Expert disagreement is analyzed and described in Section 4.5. Only the results will be discussed here. The critical F-value is the value the statistic must exceed to reject the test. If a case of significance level of $5 \%$ (with $\alpha=0.05$ and a confidence level of $95 \%$ ) is considered then this indicates that there is only one chance in twenty that this event happened by coincidence and a 0.05 level of statistical significance is being implied. The lower the significance level, the stronger the evidence required. It is conventional to use a $5 \%$ level of significance for many applications. In this research, typically group judgment quantification is accepted when the null hypothesis is rejected at the 0.01 level. This corresponds to a confidence level of $99 \%$. Rejecting the null hypothesis implies that that there is agreement amongst the experts.

For the five perspectives fulfilling the mission of assessment of PV technologies for the electric utility worldview (EUVW), hypothesis is rejected at the 0.025 level. In the case of the technical, economic, environmental, and political criteria, the null hypothesis is rejected at the 0.01 level. For the social criteria, the null hypothesis is not rejected at the 0.01 level. No attempt to reconcile the disagreement between the experts and bring the confidence level of agreements up was made since the background of the experts varied greatly. Some of the experts were based in the United States and some were international. The international experts were European and Latin American. It can be expected that the relative ranking of the social criteria by the experts would vary based on the local cultural, political, and experiential considerations. This 
important aspect should be noted for future research and is discussed further in section 7.3.12.

Criterion-related validity is also needed to review and verify the impact of the results. This was accomplished by considering the case study for a northwest United Stated electric utility and assessing five PV technologies. This represented the electric utility worldview for the candidate PV technologies. This way, the research included a systematic approach to developing a multiple perspective decision model and then its application to a real-world case. Once the results were compiled they were then presented to the decision maker expert panel representing the electric utility to confirm that the results were in line with their expectations. This panel confirmed the results.

The research and results were also presented to an independent expert for validation. This expert had over forty years experience in research and technology management and had been intimately engaged in the research and commercialization of a variety of PV technologies.

In summary, all aspects were validated qualitatively through expert reviews. The experts also expressed a strong interest in utilizing this model for future technology evaluations. 


\subsubsection{Analysis of Results with Social Criteria and Expert Disagreements}

For the contributions of the criteria to the social perspective, the null hypothesis cannot be rejected at 0.01 level. No attempt to reconcile the disagreement between the experts and bring the confidence level of agreements up was made since the experts were United States based and international. It can be expected that the relative ranking of the social criteria by the experts would vary based on the local cultural, political, and experiential considerations. This important consideration should be noted for future research.

A cluster analysis can assist in analyzing which experts were similar in their judgment quantification of the social criteria. A hierarchical cluster analysis was performed using the Ward method [100]. Ward used an agglomerative hierarchical clustering procedure, where the criterion for choosing the pair of clusters to merge at each step is based on the optimal value of error sum of squares (referred to as an objective function in the analysis). The cluster analysis of the relative rankings of the social criteria for the 10 experts was performed using the R statistical software and the hclust() function in R. The results were plotted as a dendrogram with five clusters or groups of similar experts (Figure 36). The numbers represent the individual experts; for example, "1" and "7" form group 2 and represent "Ex1-S" and "Ex7-S". (Also refer to Table 25 for the social criteria results.) 


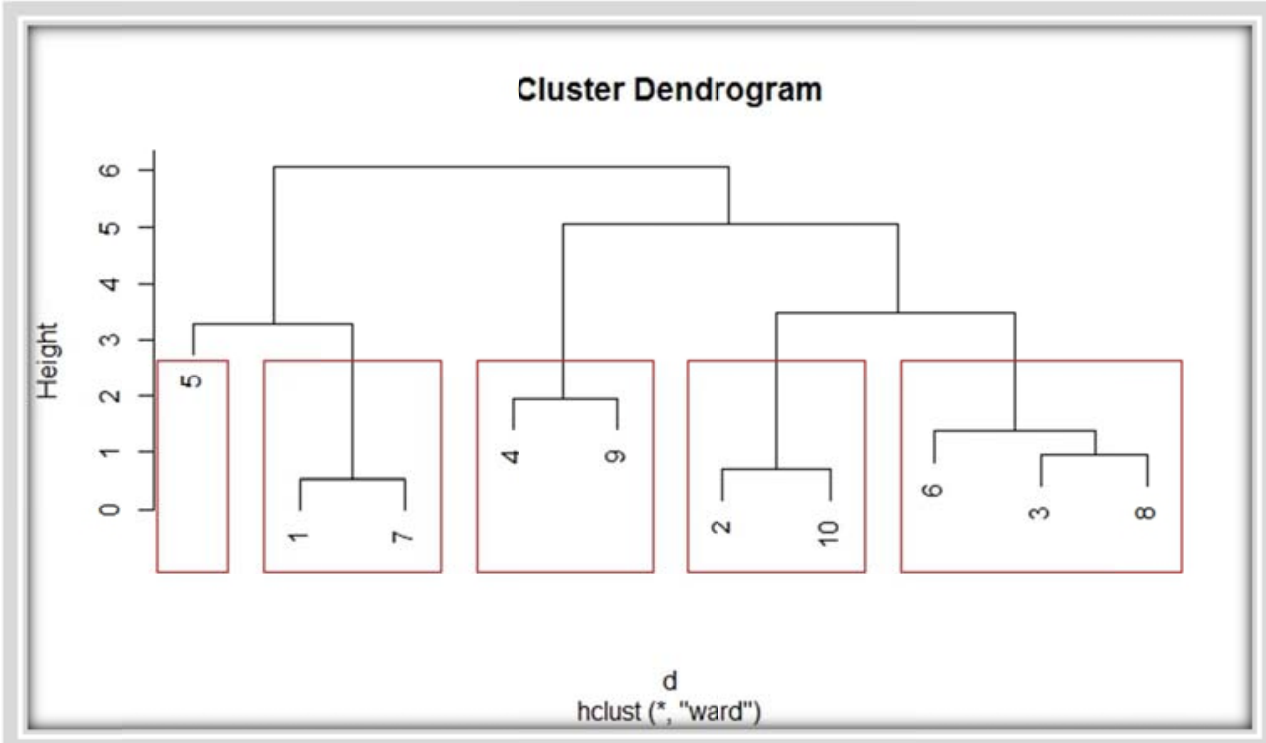

Figure 36: Cluster Analysis of Social Criteria Rankings by Experts

These four groups were considered independently-as four cases - to determine their affect on the final results with respect to the relative rankings of the five candidate technologies. For each case, this is analogous to each group's experts being the dominant opinion with all ten experts engaged. For example, in the case of group 2, the dominant opinion would be that of Ex1-S and Ex-7-S and the opinion of the other nine experts would not be as important. In this approach the arithmetic mean of the experts within each group was taken as the representative social criteria relative rank values. For example, the mean of the judgment quantifications of the two experts Ex1S and Ex7-S for group 2 were used. The social criteria values for each group are shown in Table 38. 
Table 38: Social Criteria Relative Values for Expert Groups 2 - 5

\begin{tabular}{|c|c|c|c|c|}
\hline Social Perspective (S) & 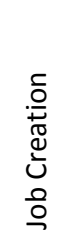 & 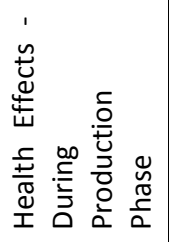 & 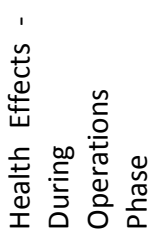 & 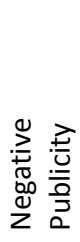 \\
\hline Group 2 (Ex1-S \& Ex7-S) & 0.49 & 0.18 & 0.18 & 0.17 \\
\hline Group 3 (Ex4-S \& Ex9-S) & 0.27 & 0.52 & 0.17 & 0.06 \\
\hline Group 4 (Ex2-S \& Ex10-S) & 0.19 & 0.33 & 0.36 & 0.13 \\
\hline Group 5 (Ex6-S, Ex3-S, \& Ex8-S) & 0.27 & 0.19 & 0.27 & 0.27 \\
\hline
\end{tabular}

For all four groups, the relative rankings of the five candidate technologies remain unchanged. The results of this analysis are shown in Table 39 and indicate that the relative rankings of the PV technologies are not affected by the disagreements of social experts.

Table 39: Recalculating PV Technology Values with Expert Groups 2 - 5 for Social Criteria

\begin{tabular}{|c|c|c|c|c|c|}
\hline $\begin{array}{c}\text { Technology } \\
\text { Values for } \\
\text { Groups 2 - 5 }\end{array}$ & $\begin{array}{c}\text { Group 2 } \\
\text { (Ex1-S \& Ex7-S) }\end{array}$ & $\begin{array}{c}\text { Group 3 } \\
\text { (Ex4-S \& Ex9-S) }\end{array}$ & $\begin{array}{c}\text { Group 4 } \\
\text { (Ex2-S \& Ex10-S) }\end{array}$ & $\begin{array}{c}\text { Group 5 } \\
\text { (Ex6-S, Ex3-S, \& } \\
\text { Ex8-S) }\end{array}$ & Rank \\
\hline C-Si & 82 & 82 & 83 & 82 & 1 \\
\hline a-Si & 81 & 81 & 82 & 81 & 2 \\
\hline CIGS & 74 & 76 & 76 & 76 & 3 \\
\hline CdTe & 73 & 75 & 61 & 60 & 4 \\
\hline OPV & 59 & 60 & & & 5 \\
\hline
\end{tabular}

\subsubsection{Sensitivity Analysis}

An effort was made to perform sensitivity analysis for "what-if scenarios" to determine the effects of varying the rank values of the STEEP perspectives and criteria. Since making changes to the perspective values would have the most impact, extreme variations in the perspective values could provide some insights into technology value 
changes. Five cases for sensitivity analysis were considered by assigning one perspective a value of 0.96 and the other perspectives value of 0.01 each. For example, considering the case of a dominant social perspective with a value of 0.96 and other STEEP perspectives at 0.01, the overall TVs changed but the rank order remain unchanged (Table 40). Similar effects were observed for the three cases of dominant technical, economic, and political perspectives as shown in Table 40. However, for the case of a dominant environmental perspective, the rank order of the candidate technologies is changed with OPV having the highest TV value. Hence, if there is a scenario where the only or overriding main consideration is environmental then OPV would become the winning technology.

Table 40: Sensitivity Analysis with a Dominant STEEP Perspective Dominant Social Perspective

\begin{tabular}{|c|c|c|c|c|c|}
\hline & $\begin{array}{c}\text { Social } \\
\text { Perspective }\end{array}$ & $\begin{array}{c}\text { Technical } \\
\text { Perspective }\end{array}$ & $\begin{array}{c}\text { Economic } \\
\text { Perspective }\end{array}$ & $\begin{array}{c}\text { Environmental } \\
\text { Perspective }\end{array}$ & $\begin{array}{c}\text { Political } \\
\text { Perspective }\end{array}$ \\
\hline $\begin{array}{l}\text { Relative } \\
\text { Ranking }\end{array}$ & $\mathbf{0 . 9 6}$ & 0.01 & 0.01 & 0.01 & 0.01 \\
\hline
\end{tabular}

\begin{tabular}{|c|c|c|c|c|c|c|c|}
\hline $\begin{array}{c}\text { PV } \\
\text { Technology }\end{array}$ & $\begin{array}{c}\text { Social } \\
\text { Perspective }\end{array}$ & $\begin{array}{c}\text { Technical } \\
\text { Perspective }\end{array}$ & $\begin{array}{l}\text { Economic } \\
\text { Perspective }\end{array}$ & $\begin{array}{l}\text { Environmental } \\
\text { Perspective }\end{array}$ & $\begin{array}{c}\text { Political } \\
\text { Perspective }\end{array}$ & $\begin{array}{l}\text { Technology } \\
\text { Value (S-TV) }\end{array}$ & $\begin{array}{l}\text { Best } \\
\text { Tech. }\end{array}$ \\
\hline$c-S i$ & 84.00 & 0.85 & 0.70 & 0.89 & 0.95 & 87.39 & $\checkmark$ \\
\hline$a-S i$ & 84.00 & 0.84 & 0.68 & 0.89 & 0.95 & 87.35 & \\
\hline CIGS & 73.50 & 0.70 & 0.66 & 0.85 & 0.95 & 76.66 & \\
\hline CdTe & 73.50 & 0.70 & 0.66 & 0.85 & 0.88 & 76.59 & \\
\hline OPV & 73.50 & 0.31 & 0.47 & 0.92 & 0.85 & 76.05 & \\
\hline
\end{tabular}

\section{Dominant Technical Perspective}

\begin{tabular}{|c|c|c|c|c|c|}
\hline & $\begin{array}{c}\text { Social } \\
\text { Perspective }\end{array}$ & $\begin{array}{c}\text { Technical } \\
\text { Perspective }\end{array}$ & $\begin{array}{c}\text { Economic } \\
\text { Perspective }\end{array}$ & $\begin{array}{c}\text { Environmental } \\
\text { Perspective }\end{array}$ & $\begin{array}{c}\text { Political } \\
\text { Perspective }\end{array}$ \\
\hline Relative & 0.01 & $\mathbf{0 . 9 6}$ & 0.01 & 0.01 & 0.01 \\
\hline
\end{tabular}




\begin{tabular}{|c|c|c|c|c|c|c|c|}
\hline Ranking & & & & & & & \\
\hline $\begin{array}{c}\text { PV } \\
\text { Technology }\end{array}$ & Social & Technical & Economic & Environmental & Political & $\begin{array}{l}\text { Technology } \\
\text { Value (T-TV) }\end{array}$ & $\begin{array}{l}\text { Best } \\
\text { Tech. }\end{array}$ \\
\hline C-Si & 0.88 & 81.79 & 0.70 & 0.89 & 0.95 & 85.20 & $\checkmark$ \\
\hline $\mathrm{a}-\mathrm{Si}$ & 0.88 & 80.34 & 0.68 & 0.89 & 0.95 & 83.73 & \\
\hline CIGS & 0.77 & 67.54 & 0.66 & 0.85 & 0.95 & 70.77 & \\
\hline CdTe & 0.77 & 67.54 & 0.66 & 0.85 & 0.88 & 70.70 & \\
\hline OPV & 0.77 & 29.35 & 0.47 & 0.92 & 0.85 & 32.36 & \\
\hline
\end{tabular}

\section{Dominant Economic Perspective}

\begin{tabular}{|c|c|c|c|c|c|}
\hline & $\begin{array}{c}\text { Social } \\
\text { Perspective }\end{array}$ & $\begin{array}{c}\text { Technical } \\
\text { Perspective }\end{array}$ & $\begin{array}{c}\text { Economic } \\
\text { Perspective }\end{array}$ & $\begin{array}{c}\text { Environmental } \\
\text { Perspective }\end{array}$ & $\begin{array}{c}\text { Political } \\
\text { Perspective }\end{array}$ \\
\hline $\begin{array}{l}\text { Relative } \\
\text { Ranking }\end{array}$ & 0.01 & 0.01 & $\mathbf{0 . 9 6}$ & 0.01 & 0.01 \\
\hline
\end{tabular}

\begin{tabular}{|c|c|c|c|c|c|c|c|}
\hline $\begin{array}{c}\text { PV } \\
\text { Technology }\end{array}$ & Social & Technical & Economic & Environmental & Political & $\begin{array}{c}\text { Technology } \\
\text { Value (E-TV) }\end{array}$ & $\begin{array}{c}\text { Best } \\
\text { Tech. }\end{array}$ \\
\hline c-Si & 0.88 & 0.85 & 67.04 & 0.89 & 0.95 & 70.61 & $\checkmark$ \\
\hline a-Si & 0.88 & 0.84 & 65.04 & 0.89 & 0.95 & 68.60 & \\
\hline CIGS & 0.77 & 0.70 & 63.45 & 0.85 & 0.95 & 66.72 & \\
\hline CdTe & 0.77 & 0.70 & 63.61 & 0.85 & 0.88 & 66.81 & \\
\hline OPV & 0.77 & 0.31 & 44.88 & 0.92 & 0.85 & 47.72 & \\
\hline
\end{tabular}

\section{Dominant Environmental Perspective}

\begin{tabular}{|c|c|c|c|c|c|}
\hline & $\begin{array}{c}\text { Social } \\
\text { Perspective }\end{array}$ & $\begin{array}{c}\text { Technical } \\
\text { Perspective }\end{array}$ & $\begin{array}{c}\text { Economic } \\
\text { Perspective }\end{array}$ & $\begin{array}{c}\text { Environmental } \\
\text { Perspective }\end{array}$ & $\begin{array}{c}\text { Political } \\
\text { Perspective }\end{array}$ \\
\hline $\begin{array}{l}\text { Relative } \\
\text { Ranking }\end{array}$ & 0.01 & 0.01 & 0.01 & $\mathbf{0 . 9 6}$ & 0.01 \\
\hline
\end{tabular}

\begin{tabular}{|c|c|c|c|c|c|c|c|}
\hline $\begin{array}{c}\text { PV } \\
\text { Technology }\end{array}$ & Social & Technical & Economic & Environmental & Political & $\begin{array}{c}\text { Technology } \\
\text { Value (En-TV) }\end{array}$ & $\begin{array}{c}\text { Best } \\
\text { Tech. }\end{array}$ \\
\hline c-Si & 0.88 & 0.85 & 0.70 & 85.24 & 0.95 & 88.62 & \\
\hline a-Si & 0.88 & 0.84 & 0.68 & 85.24 & 0.95 & 88.58 & \\
\hline CIGS & 0.77 & 0.70 & 0.66 & 81.56 & 0.95 & 84.64 & \\
\hline CdTe & 0.77 & 0.70 & 0.66 & 81.56 & 0.88 & 84.56 & \\
\hline OPV & 0.77 & 0.31 & 0.47 & 88.54 & 0.85 & 90.93 & $\checkmark$ \\
\hline
\end{tabular}


Dominant Political Perspective

\begin{tabular}{|c|c|c|c|c|c|}
\hline & $\begin{array}{c}\text { Social } \\
\text { Perspective }\end{array}$ & $\begin{array}{c}\text { Technical } \\
\text { Perspective }\end{array}$ & $\begin{array}{c}\text { Economic } \\
\text { Perspective }\end{array}$ & $\begin{array}{c}\text { Environmental } \\
\text { Perspective }\end{array}$ & $\begin{array}{c}\text { Political } \\
\text { Perspective }\end{array}$ \\
\hline $\begin{array}{l}\text { Relative } \\
\text { Ranking }\end{array}$ & 0.01 & 0.01 & 0.01 & 0.01 & $\mathbf{0 . 9 6}$ \\
\hline
\end{tabular}

\begin{tabular}{|c|c|c|c|c|c|c|c|}
\hline $\begin{array}{c}\text { PV } \\
\text { Technology }\end{array}$ & Social & Technical & Economic & Environmental & Political & $\begin{array}{c}\text { Technology } \\
\text { Value (P-TV) }\end{array}$ & $\begin{array}{c}\text { Best } \\
\text { Tech. }\end{array}$ \\
\hline c-Si & 0.88 & 0.85 & 0.70 & 0.89 & 91.33 & 94.65 & $\checkmark$ \\
\hline a-Si & 0.88 & 0.84 & 0.68 & 0.89 & 91.33 & 94.61 & \\
\hline CIGS & 0.77 & 0.70 & 0.66 & 0.85 & 91.33 & 94.31 & \\
\hline CdTe & 0.77 & 0.70 & 0.66 & 0.85 & 84.22 & 87.20 & \\
\hline OPV & 0.77 & 0.31 & 0.47 & 0.92 & 81.85 & 84.31 & \\
\hline
\end{tabular}




\section{RESEARCH ASSUMPTIONS AND LIMITATIONS}

\subsection{Research Assumptions}

This research is heavily dependent on a decision model based on the judgment of experts. Certain assumptions were made regarding the experts and modeling and every effort was made to comply with these assumptions. The assumptions included:

- The selected experts participating in the expert panels were assumed to be very knowledgeable in their respective areas. They would also be able to quantify their judgment values. For example, the social perspective experts were social scientists and had domain knowledge of renewable and solar energy. The typical experience level of the experts was 15-20 years in academia, research, or industry.

- It is natural to assume that the input from the experts would include their personal and experiential biases. To compensate for this every effort was made to form well-balanced expert panels from experts who have different experiences and positions. This can be verified by referring to the list of experts in Table 20.

- The results of this modeling process can change over time since it reflects the preferences and judgments of the experts at a certain point in time. The model is designed to allow for variations as situations and conditions change. This can be done by changing the relative ranking values of the perspectives and criteria and recalculating the resulting decision outcome for the candidate 
technologies. Special "what-if" cases of the changes are shown in Section 4.3.5 on sensitivity analysis.

The assumptions for the hierarchical decision modeling included:

- The hierarchical decision model is developed such that there is a unidirectional hierarchical relationship between the levels. This was tested before the judgment quantification process started.

- The decision model elements at the same level in the hierarchical modelperspectives and criteria-are assumed to be collectively exhaustive and preferentially independent. This was verified by the experts.

- The impact relationships occurring in the model are linear and additive. This is an inherent characteristic of HDM.

\subsection{Limitations}

This HDM proved to be a useful methodology for subjective ranking of the perspectives and criteria for PV technology assessment. However, it has some limitations, such as:

- This approach although useful to gain insight into ranking of perspectives and criteria is based on the worldview of the decision makers. The outcomes cannot directly be applied to a different set of decision makers with a different set of priorities. However, sensitivity analysis can help alleviate this limitation. 
- The relative priority among all STEEP perspectives and the relative contribution of the STEEP criteria are based on a point in time. The priorities, preferences, and judgments reflect that time. With time these priorities and preferences can change. Hence, if the decision makers perceive any changes that can affect the decision outcomes, then the priorities and relative contributions need to be re-evaluated. Again, as mentioned earlier this may done through sensitivity analysis.

- The HDM is fixed for the perspectives and criteria that are the model elements. Any changes-additions or deletions of model elements-require re-evaluating the relatives ranking of these elements implying a repeat of the entire expert judgment quantification process.

- Other approaches for PV technology assessment may be simpler such as using only the top STEEP perspectives or criteria that are considered important by the industry or targeted worldview. 


\section{CONCLUSIONS}

\subsection{Research Outcomes}

A robust HDM was developed for the assessment of PV technologies using STEEP perspectives. Expert judgment quantification was utilized to rank the criteria under each perspective. Experts also helped to construct desirability functions to map criterion performance metrics to desirability values. The model was then completed for a United Stated Northwest electric utility worldview to compare five candidate PV technologies: c-Si, a-Si, CIGS, CdTe, and OPV. In this scenario c-Si was the top ranked technology followed by a-Si as close second. OPV was the lowest ranked PV technology. Recommendations for the improvement of those criteria set that could enable OPV to become the top ranked technology were provided as an operationalization case study. Sensitivity analysis was also performed to determine PV technology ranking variations for five cases. In each case only one perspective was dominant. The rank order of the candidate technologies did not change under these cases except when the environmental perspective was dominant. In this case OPV became the top-ranked PV technology. The research results were validated throughout the research process. 


\subsection{Research Contributions}

\subsubsection{Contribution 1: Contribution to the Body of Knowledge}

The broad contribution of this research is described in Chapter 0 and in summary it is the development of a decision making model that will enable a comprehensive assessment of PV technologies to assist policy makers, technology suppliers, energy utilities, universities/research institutes/national labs to make better decisions on technology evaluation and commercialization. The research is demonstrated for the electric utility worldview. This is accomplished by a northwest United States power utility case study.

\subsubsection{Contribution 2: Gaps in Research Identified}

The literature review revealed gaps found in technology assessment considering the five STEEP perspectives. The gaps identified in the literature and the suggestions made by researchers have been addressed in this dissertation. Typically all five STEEP perspectives are not considered in one evaluation. Journal papers tend to be focused around 3 clusters of perspectives: (1) Technical and Economical (TE), (2) Social and Political (SP), and (3) Social, Environmental, and Political (SEP) 


\subsubsection{Contribution 3: Hierarchical Decision Model for Assessment of PV Technologies}

A comprehensive assessment of technologies that have broad societal implications should include social, technical, economic, environmental, and political (STEEP) perspectives and their decision inputs from salient stakeholders and constituencies. The perspectives are composed of criteria that compete against each other and may represent quantitative and qualitative measurements. This makes the decision process difficult to manage. A multicriteria decision model (MCDM) is valuable in providing technology assessment under such conditions. This research indicates that HDM is a robust MCDM model that can be applied to technology assessments with recommendations for areas of improvement. HDM utilizes expert judgments to provide relative rank values of the criteria by a pairwise comparison constant sum method which enables judgments, inconsistencies, and disagreements to be explicitly managed. The model framework was originally developed by Dr. Dundar Kocaoglu and has been proven effective in diverse applications. This research is focused on the use of HDM for assessment of PV technologies using the STEEP perspectives and makes no claims beyond that.

Current research involves only subsets of the STEEP perspectives utilized for technology ranking and assessment. There is also no known research in building a technology value function from the criteria and desirability functions for gap analysis 
and recommendations for action. This makes the analysis operational and actionable by the electric utilities, technology suppliers, or policy makers.

By assessing PV technologies using the HDM approach, this research also enables the following contributions:

- Expert judgments are explicit and quantified at different levels of granularity. This enables insights into expert judgments at deeper levels.

- Use of sensitivity analysis to determine changes in technology assessment based on variations in the relative priorities of the perspectives and criteria.

- Ability to use HDM for different worldviews based on the priorities at the STEEP perspectives level. The criteria rankings may be kept the same. Different worldviews may result in different decision outcomes.

- Ability to add new candidate technologies in the assessment process without any changes to HDM. This is a great benefit since PV technologies are constantly evolving and changing.

\subsection{Future Research}

This research focused on the assessment of PV technologies using the STEEP perspectives and hierarchical decision modeling. This approach could be extended in several areas for future research: 
- Reconsidering the initial 200+ criteria and factors, the decision model can be developed for other forms of renewable energy such as wind energy, hydroelectric energy, geothermal energy, and ocean energy, and biomass energy. This is in line with the research at RISE.

- Use of extensive sensitivity analysis for assessment of PV technologies to assist decisions makers over an extended period as priorities, situations, and technologies change.

- The disagreement level among experts was higher in the case of the social criteria. This is an opportunity for more in-depth multivariate statistical analysis such as factor and cluster analysis to better understand the causes of the disagreement. This would be an extension of the initial investigation presented in this dissertation.

- The model supports the addition of other candidate PV technologies or a new set of technologies altogether. As new technologies are commercialized they can be added for assessment. Also, different worldviews may require the assessment of a new set of technologies. For example, the policy makers' worldview may require the need to decide which emerging PV technologies to fund. Hence only new and emerging candidate technologies would be considered.

This research can extend in multiple directions in depth and breadth as exemplified by the above indicated areas. 


\section{REFERENCES}

[1] I. Dincer, "Environmental impacts of energy," Energy Policy, vol. 27, no. 14, pp. 845-854, Dec. 1999.

[2] R. K. Dixon, E. McGowan, G. Onysko, and R. M. Scheer, "US energy conservation and efficiency policies: Challenges and opportunities," Energy Policy, pp. 1-11, Feb. 2010.

[3] A. C. Marques, J. a. Fuinhas, and J. R. Pires Manso, "Motivations driving renewable energy in European countries: A panel data approach," Energy Policy, vol. 38, no. 11, pp. 6877-6885, Nov. 2010.

[4] N. J. Sheikh and T. U. Daim, "Renewable Energy Policies that Impact Climate Change - The Case for Photovoltaic Solar Technology," in Educational and Technological Approaches to Renewable Energy, W. L. Filho and J. Gottwald, Eds. Peter Lang, 2012, pp. 183-211.

[5] P. Meier and V. Mubayi, "Modelling energy-economic interactions in developing countries: A linear programming approach," European Journal of Operational Research, vol. 13, no. 1, pp. 41-59, May 1983.

[6] S. Pohekar and M. Ramachandran, "Application of multi-criteria decision making to sustainable energy planning-A review," Renewable and Sustainable Energy Reviews, vol. 8, no. 4, pp. 365-381, 2004.

[7] J. Samouilidis and C. Mitropoulos, "Energy-economy models: A survey," European Journal of Operational Research, vol. 11, no. 3, pp. 222-232, Nov. 1982.

[8] "Advanced Photovoltaic Technology," New Energy Strategies - Market Research Report, 2010.

[9] L. Kazmerski, "Best Research Cell Efficiencies Chart," National Renewable Energy Laboratory (NREL), 2010. [Online]. Available:

http://en.wikipedia.org/wiki/File:PVeff(rev100414).png.

[10] "Trends in Photovoltaic Technology," New Energy Strategies - Market Research Report, 2010. 
[11] H. A. Linstone, "The Multiple Perspective Concept with Applications to Technology Assessment and Other Decision Areas," Technological Forecasting and Social Change, vol. 20, no. 4, pp. 275-325, Dec. 1981.

[12] H. Linstone, Decision-Making For Technology Executives Using Multiple Perspectives to Improve Performance. Artech House, 1999.

[13] H. A. Linstone, "Multiple Perspectives Redux," Technological Forecasting and Social Change, vol. 77, no. 4, pp. 696-698, May 2010.

[14] H. A. Linstone, "Multiple Perspectives: Overcoming the Weaknesses of MS/OR," Interfaces, vol. 15, no. 4, pp. 77-85, Jul. 1985.

[15] N. Sheikh and D. F. Kocaoglu, "A Comprehensive Assessment of Solar Photovoltaic Technologies: Literature Review," Technology Management in the Energy Smart World (PICMET), 2011 Proceedings of PICMET '11, no. July 31 Aug 4, pp. 1-11, 2011.

[16] J. J. Conti, “Annual Energy Outlook 2010 With Projections to 2035," U.S. Energy Information Administartion, vol. DOE/EIA-03, no. April, 2010.

[17] “Energy Technology Roadmaps: Charting a low-carbon energy revolution,” 2009.

[18] EPIA, "Global market outlook for photovoltaics until 2014," European Photovoltaic Industry Association, 2010.

[19] C. Augustine, A. Byrne, I. H. Eric Gimon, Tomas Goerner, and D. Kammen, "Redefining What's Possible for Clean Energy by 2020," Gigaton Throwdown Initiative, no. June, 2009.

[20] "The Recovery Act: Transforming the American Economy through innovation," Office of the Vice President - US, pp. 1-50, 2010.

[21] L. Kazmerski, "Best Research Cell Efficiencies Chart," National Renewable Energy Laboratory (NREL), 2012. [Online]. Available: http://en.wikipedia.org/wiki/File:PVeff\%28rev120820\%29.jpg. [Accessed: 04Mar-2013].

[22] J. Chiavari, "IEA Accelerating Energy Technology Innovation Project: Summary Report - First Advisory Group Meeting 29-30 June 2010," International Energy Agency, 2010. 
[23] B. Azzopardi and J. Mutale, "Life cycle analysis for future photovoltaic systems using hybrid solar cells," Renewable and Sustainable Energy Reviews, vol. 14, pp. 1130-1134, 2009.

[24] G. W. Braun and D. E. Skinner, "Experience Scaling-Up Manufacturing of Emerging Photovoltaic Technologies," NREL Technical Monitor, no. January, 2007.

[25] F. Cavallaro, "A comparative assessment of thin-film photovoltaic production processes using the ELECTRE III method," Energy Policy, vol. 38, no. 1, pp. 463474, Jan. 2010.

[26] S. Bowden, C. Honsberg, and D. Schroder, "Moore 's Law of Photovoltaics," Future Photovoltaics, no. May, 2010.

[27] A. E. Curtright, M. G. Morgan, and D. W. Keith, "Expert assessments of future photovoltaic technologies," Environmental Science and Technology, vol. 42, no. 24, pp. 9031-9038, 2008.

[28] L. Schwartz, "Chinese Firms Developing Solar Power Plants for Less Than 1 Yuan per kWh?," RenewableEnergyWorld.com, 2010. [Online]. Available: http://www.renewableenergyworld.com/rea/news/article/2010/09/chinesefirms-developing-solar-power-plants-for-less-than-1-yuan-perkwh?cmpid=WNL-Wednesday-September22-2010. [Accessed: 01-Jan-2011].

[29] C. Brabec, "Organic photovoltaics: technology and market," Solar Energy Materials and Solar Cells, vol. 83, no. 2-3, pp. 273-292, Jun. 2004.

[30] M. A. Eltawil and Z. Zhao, "Grid-connected photovoltaic power systems: Technical and potential problems-A review," Renewable and Sustainable Energy Reviews, vol. 14, pp. 112-129, 2009.

[31] B. Marion, J. Adelstein, K. Boyle, H. Hayden, B. Hammond, T. Fletcher, B. Canada, D. Narang, D. Shugar, H. Wenger, A. Kimber, L. Mitchell, G. Rich, T. Townsend, and L. B. Vista, "Performance Parameters for Grid-Connected PV Systems," Renewable Energy, no. February, 2005.

[32] C.-J. Yang, "Reconsidering solar grid parity," Energy Policy, vol. 38, no. 7, pp. 3270-3273, Jul. 2010.

[33] T. Tsoutsos, "Environmental impacts from the solar energy technologies," Energy Policy, vol. 33, no. 3, pp. 289-296, Feb. 2005. 
[34] R. Chiabrando, E. Fabrizio, and G. Garnero, "The territorial and landscape impacts of photovoltaic systems: Definition of impacts and assessment of the glare risk," Renewable and Sustainable Energy Reviews, vol. 13, pp. 2441-2451, 2009.

[35] S. Awerbuch, "Investing in photovoltaics: risk, accounting and the value of new technology," Energy Policy, vol. 28, no. 14, pp. 1023-1035, Nov. 2000.

[36] B. Nelson, "Standards Can Take PV to Its Gold Medal Game," Future Photovoltaics, no. May, 2010.

[37] K. Degroat, J. Morabito, T. Peterson, and G. P. Smestad, "Systems Analysis and Recommendations for R\&D and Accelerated Deployment of Solar Energy," Sol Ideas Technology Development \& Solar Energy Materials and Solar Cells Journal, pp. 1-16, 2009.

[38] R. Haas, "Market deployment strategies for photovoltaics: an international review," Renewable and Sustainable Energy Reviews, vol. 7, pp. 271-315, 2003.

[39] T. Jackson and M. Oliver, "The viability of solar photovoltaics," Southern Economic Journal, vol. 28, no. 2000, pp. 983-988, 2000.

[40] E. A. Alsema and E. Nieuwlaar, "Energy viability of photovoltaic systems," Energy Policy, vol. 28, no. 14, pp. 999-1010, Nov. 2000.

[41] IEA, "Trends in Photovoltaic Applications: Survey report of selected IEA countries between 1992 and 2007," International Energy Agency - Photovoltiac Power Systems Programme, vol. IEA-PVPS, no. T1-17, 2008.

[42] J. Paidipati, L. Frantzis, H. Sawyer, A. Kurrasch, and R. Margolis, "Rooftop Photovoltaics Market Penetration Scenarios," NREL Technical Monitor, vol. NREL/SR-58, no. February, 2008.

[43] H. Ibrahim, A. Ilinca, and J. Perron, "Energy storage systems-Characteristics and comparisons," Renewable and Sustainable Energy, vol. 12, pp. 1221-1250, 2008.

[44] H. Linstone, Decision Making for Technological Executives: Using Multiple Perspectives to Improve Performance, vol. 71, no. 7. Boston, MA: Artech House, 1999.

[45] Mindtools.com, "PEST Analysis-Problem-Identifying 'Big Picture' Opportunities and Threats," Mindtools.com. [Online]. Available: 
http://www.mindtools.com/pages/article/newTMC_09.htm. [Accessed: 20-Mar2013].

[46] M. Elle, S. Dammann, J. Lentsch, and K. Hansen, "Learning from the social construction of environmental indicators: From the retrospective to the proactive use of SCOT in technology development," Building and Environment, vol. 45, no. 1, pp. 135-142, 2009.

[47] S. Jebaraj and S. Iniyan, "A review of energy models," Renewable and Sustainable Energy Reviews, vol. 10, pp. 281-311, 2006.

[48] F. A. Lootsma, J. Meisner, and F. Schellemans, "Multi-criteria decision analysis as an aid to the strategic planning of energy R\& D," European Journal of Operational Research, vol. 25, pp. 216-234, 1986.

[49] H. Polatidis and D. a. Haralambopoulos, "Decomposition Analysis and Design of Sustainable Renewable Energy Systems: A New Approach," Energy Sources, Part B: Economics, Planning, and Policy, vol. 2, no. 4, pp. 371-380, Oct. 2007.

[50] M. Behzadian, R. B. Kazemzadeh, A. Albadvi, and M. Aghdasi, "PROMETHEE: A comprehensive literature review on methodologies and applications," European Journal of Operational Research, vol. 200, no. 1, pp. 198-215, 2010.

[51] D. Diakoulaki, C. H. Antunes, and A. G. Martins, "MCDA and Energy Planning," in Multiple Criteria Decision Analysis: State of the Art Surveys, vol. Chapter 21, no. Springer Verlag, 2005, pp. 859-898.

[52] E. Loken, "Use of multicriteria decision analysis methods for energy planning problems," Renewable and Sustainable Energy Reviews, vol. 11, no. 7, pp. 15841595, Sep. 2007.

[53] M. Pirdashti, A. Ghadi, M. Mohammadi, and G. Shojatalab, "Multi-Criteria Decision-Making Selection Model with Application to Chemical Engineering Management Decisions," International Journal of Business, Economics, Finance and Management Sciences, vol. 1, no. 3, pp. 228-233, 2009.

[54] J.-J. Wang, Y.-Y. Jing, C.-F. Zhang, and J.-H. Zhao, "Review on multi-criteria decision analysis aid in sustainable energy," Renewable and Sustainable Energy Reviews, vol. 13, pp. 2263-2278, 2009.

[55] P. Zhou, B. Ang, and K. Poh, "Decision analysis in energy and environmental modeling: An update," Energy, vol. 31, no. 14, pp. 2604-2622, Nov. 2006. 
[56] R. Margolis and J. Zuboy, “Nontechnical Barriers to Solar Energy Use: Review of Recent Literature," National Renewable Energy Laboratory, vol. Technical , no. September, 2006.

[57] A. Menegaki, "Valuation for renewable energy: A comparative review," Renewable and Sustainable Energy Reviews, vol. 12, no. 9, pp. 2422-2437, Dec. 2008.

[58] H. Polatidis and D. Haralambopoulos, "Renewable energy systems: A societal and technological platform," Renewable Energy, vol. 32, no. 2, pp. 329-341, Feb. 2007.

[59] H. Scheer, "Solar energy's economic and social benefits," Solar Energy Materials and Solar Cells, vol. 38, no. 1, pp. 555-568, 1995.

[60] I. Linkov, F. K. Satterstrom, G. Kiker, T. P. Seager, T. Bridges, K. H. Gardner, S. H. Rogers, D. A. Belluck, and A. Meyer, "Multicriteria Decision Analysis: A Comprehensive Decision Approach for Management of Contaminated Sediments.," Risk analysis : an official publication of the Society for Risk Analysis, vol. 26, no. 1, pp. 61-78, Feb. 2006.

[61] J. Wallenius, J. S. Dyer, P. C. Fishburn, R. E. Steuer, S. Zionts, and K. Deb, "Multiple Criteria Decision Making, Multiattribute Utility Theory: Recent Accomplishments and What Lies Ahead," Management Science, vol. 54, no. 7, pp. 1336-1349, Jul. 2008.

[62] D. F. Kocaoglu, "Hierarchical Decision Modeling." .

[63] H. Polatidis, D. Haralambopoulos, G. Munda, and R. Vreeker, "Selecting an Appropriate Multi-Criteria Decision Analysis Technique for Renewable Energy Planning," Energy Sources, Part B: Economics, Planning, and Policy, vol. 1, no. 2, pp. 181-193, Jul. 2006.

[64] H. C. Doukas, B. M. Andreas, and J. E. Psarras, "Multi-criteria decision aid for the formulation of sustainable technological energy priorities using linguistic variables," European Journal of Operational Research, vol. 182, no. 2, pp. 844855, 2007.

[65] R. Madlener, K. Kowalski, and S. Stagl, "New ways for the integrated appraisal of national energy scenarios: The case of renewable energy use in Austria," Energy Policy, vol. 35, no. 12, pp. 6060-6074, Dec. 2007. 
[66] T. Saaty, F. Ma, and P. Blair, "Operational gaming for energy policy analysis," Energy Policy, vol. 5, no. 1, pp. 63-75, 1977.

[67] T. Gurbuz, Y. E. Albayrak, Y. C. Erensal, and M. Ozyol, “An Analytic Network Process Approach To The Planning And Managing Of The Energy Politics," Conference on Computers \& Industrial Engineering, 2009, pp. 1690-1693, 2009.

[68] L. M. Meade and A. Presley, "R \& D Project Selection Using the Analytic Network Process," IEEE Transactions on Engineering Management, vol. 49, no. 1, pp. 5966, 2002.

[69] Y.-C. Shen, G. T. R. Lin, K.-P. Li, and B. J. C. Yuan, “An assessment of exploiting renewable energy sources with concerns of policy and technology," Energy Policy, vol. 38, pp. 4604-4616, Aug. 2010.

[70] M. Hersh, "Sustainable decision making: the role of decision support systems," in IEE Colloquium on Decision Making and Problem Solving (Digest No: 1997/366), 1997, pp. 6/1-5.

[71] M. N. Sharif and V. Sundararajan, "A Quantitative Model for the Evaluation of Technological Alternatives," Technological Forecasting \& Social Change, vol. 24, no. 1, pp. 15-29, 1983.

[72] S. Mincer, "Amid Solyndra Scandal, Head of DOE Loan Program Resigns," AOL Energy, 2011. [Online]. Available: http://energy.aol.com/2011/10/06/amidsolyndra-scandal-head-of-doe-loan-program-resigns/. [Accessed: 12-Oct-2011].

[73] K. Korosec, "Why Solyndra failed and the DOE Loan Program is Next," 2011. [Online]. Available: http://www.smartplanet.com/blog/intelligent-energy/whysolyndra-failed-and-the-doe-loan-program-is-next/8396. [Accessed: 12-Oct2011].

[74] H. Chen, "Sensitivity Analysis for Hierarchical Decision Models," PhD Dissertation - Portland State University, 2007.

[75] M. A. Meyer and J. M. Booker, Eliciting and Analyzing Expert Judgment: A Practical Guide. Society for Industrial and Applied Mathematics, 2001.

[76] R. L. Keeney and D. von Winterfeldt, "Eliciting Probabilities from Experts in Complex Technical Problems," IEEE Transactions on Engineering Management, vol. 38, no. 3, pp. 191-201, 1991. 
[77] P. Slottje, A. B. Knol, and J. P. Van Der Sluijs, "Expert Elicitation: Methodological suggestions for its use in environmental health impact assessments," National Institute for Public Health and the Environment (RIVM Letter Report), 2008.

[78] L. Goldman, Social Impact Analysis: An Applied Anthropology Manual. New York, NY: Berg, 2000.

[79] D. D. Heckathorn, "Respondent-Driven Sampling: A New Approach to the Study of Hidden Populations," Social Problems, vol. 44, no. 2, pp. 174-199, 1997.

[80] D. D. Heckathorn, "Respondent-Driven Sampling II: Deriving Valid Population Estimates from Chain-Referral Samples of Hidden Populations," Social Problems, vol. 49, no. 1, pp. 11-34, 2002.

[81] J. J. Castillo, "Snowball Sampling," 2009. [Online]. Available:

http://www.experiment-resources.com/snowball-sampling.html.

[82] S. A. Morris and B. Van der Veer Martens, "Mapping Research Specialties," Annual Review of Information Science and Technology, vol. 42, pp. 213-295, 2008.

[83] P. Shah, “Expert Finding Using Social Networking," Master's Projects, no. 48, pp. 1-68, 2009.

[84] G. Demartini, "Finding Experts Using Wikipedia," 2nd International ExpertFinder Workshop (FEWS2007), pp. 33-41, 2007.

[85] C. Levitt, "How to Find and Research Experts on the Internet," 2012. [Online]. Available: http://www.lacba.org/showpage.cfm?pageid=1620.

[86] P. E. Shrout and J. L. Fleiss, "Intraclass correlations: uses in assessing rater reliability," Psychological bulletin, vol. 86, no. 2, pp. 420-8, Mar. 1979.

[87] D. J. Sheskin, Handbook of Parametric and Nonparametric Statistical Procedures. Chapman \& Hall/CRC Publisher, 2007.

[88] N. Gerdsri and D. F. Kocaoglu, "A Quantitative Model for the Strategic Evaluation of Emerging Technologies," Proceedings of the Portland International Conference on Management of Engineering and Technology, Portland (PICMET), Seoul, Korea, 2004.

[89] N. Sheikh, T. Daim, and D. F. Kocaoglu, "Use of Multiple Perspectives and Decision Modeling for PV Technology Assessment," Technology Management in 
the Energy Smart World (PICMET), 2011 Proceedings of PICMET '11, no. July 31 Aug. 4, pp. 1-21, 2011.

[90] N. Gerdsri and D. F. Kocaoglu, "An Analytical Approach to Building A Technology Development Envelope (TDE) for Roadmapping of Emerging Technologies: A Case Study of Emerging Electronic Cooling Technologies for Computer Servers," PICMET '03: Portland International Conference on Management of Engineering and Technology Technology Management for Reshaping the World, pp. 380389, 2003.

[91] NIST/SEMATECH, "e-Handbook of Statistical Methods," 2006. [Online]. Available: http://www.itl.nist.gov/div898/handbook. [Accessed: 26-Jan-2012].

[92] B. F. Baird, Managerial Decisions Under Uncertainty: An Introduction to the Analysis of Decision Making. John Wiley and Sons, 1989, pp. 317-351.

[93] R. Robins, "A Study of the Validity and Predictors of Standard Gamble and Time Trade-Off Visual Utilities in Patients with Retinal Disease," Queen's University, Kingston, Ontario, Canada, 2002.

[94] Mosby, "Standard Reference Gamble," Mosby's Medical Dictionary, 8th Edition, 2009. [Online]. Available: http://medicaldictionary.thefreedictionary.com/standard+reference+gamble. [Accessed: 26Jan-2012].

[95] N. L. Sproull, Handbook of research methods: a guide for practitioners and students in the social sciences, 2nd Editon. Metuchen, New Jersey: The Scarecrow Press, 2002.

[96] E. R. Babbie, The Practice of Social Research, 12th Editi. Belmont, California: Wadsworth, 2007.

[97] N. J. Sheikh, D. F. Kocaoglu, and L. Lutzenhiser, "Social and Political Impacts of Renewable Energy," Manuscript submitted for publication, pp. 1-23, 2013.

[98] P. Gerdsri, "A Systematic Approach to Developing National Technology Policy and Strategy for Emerging Technologies," Portland State University, 2009.

[99] D. F. Kocaoglu, "A Participative Approach to Program Evaluation," IEEE Transactions on Engineering Management, no. 3, pp. 112-118, 1983.

[100] J. H. Ward, "Hierarchical Grouping to Optimize an Objective Function," Journal of the American Statistical Association, vol. 58, no. 301, pp. 236-244, 1963. 


\section{APPENDIX A: INITIAL JUDGMENT QUANTIFICATION INSTRUMENT}

\section{Appendix A: Initial Judgment Quantification Instrument}

[Note: The judgment quantification instrument was a Microsoft Excel 2007 worksheet which was filled out by the participants according to the instructions.]

Solar Photovoltaic (PV) Technology Assessment Using Multiple Perspectives

Use of a Hierarchical Decision Model and Pairwise Comparisons to Obtain Relative Importance of Perspectives and Criteria for the Assessment of PV Technologies

Before starting, print and review the tabs/worksheets: (1) Questionnaire, (2) HDM Diagram, (3) STEEP Criteria \& Factors.

Name:

1

The mission of this study is to provide a comprehensive assessment of PV Technologies, using five perspectives (Social, Technical, Economic, Environmental, and Political).

To determine the relative importance of the five perspectives with respect to the mission, please compare the elements (perspectives) in each pair below. Allocate a total of 100 points to reflect how many times a perspective is important in comparison to the other. You only need to enter the value of the 1st element. [Do not enter "0".] The value of the other element will be calculated automatically. Given below are a few examples:

If the 1st element is 4 times as important as the 2 nd element, enter " 80 " points for the 1 st element. The 2 nd element will get 20 points.

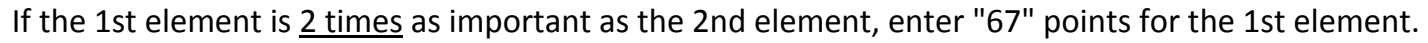
The 2 nd element will get 33 points.

If the 1 st element is the same in importance as the 2 nd element, enter " 50 " points for the 1 st element. The 2 nd element will also get 50 points.

If the 1 st element is $1 / 3$ as important as the 2 nd element, enter "25" points for the 1 st element. The 2nd element will get 75 points.

\begin{tabular}{|c|c|c|}
\hline Social Perspective & vs & Technical Perspective \\
\hline Social Perspective & vs & Economic Perspective \\
\hline Social Perspective & vs & Environmental Perspective \\
\hline Social Perspective & vs & Political Perspective \\
\hline Technical Perspective & vs & Economic Perspective \\
\hline Technical Perspective & vs & Environmental Perspective \\
\hline
\end{tabular}




\begin{tabular}{|c|c|c|}
\hline Technical Perspective & vs & Political Perspective \\
\hline Economic Perspective & vs & Environmental Perspective \\
\hline Economic Perspective & vs & Political Perspective \\
\hline Environmental Perspective & vs & Political Perspective \\
\hline
\end{tabular}

2a Considering only the Social Perspective to assess PV technologies, please compare the relative importance of a criteria in each pair with the other one. Examples of criteria include public perception, employment, health \& safety, local infrastructure development, etc. To further understand each criterion, refer to the worksheet "STEEP Criteria \& Factors". For example, Public Perception criterion is composed of factors such as aesthetics, impact of lifestyle, impact on property value, impact on tourism, etc.

\begin{tabular}{|c|c|c|}
\hline Public Perception & vs & Employment \\
\hline Public Perception & vs & Health \& Safety \\
\hline Public Perception & vs & $\begin{array}{l}\text { Local Infrastructure } \\
\text { Development }\end{array}$ \\
\hline Employment & vs & Health \& Safety \\
\hline Employment & vs & $\begin{array}{l}\text { Local Infrastructure } \\
\text { Development }\end{array}$ \\
\hline Health \& Safety & vs & $\begin{array}{l}\text { Local Infrastructure } \\
\text { Development }\end{array}$ \\
\hline
\end{tabular}


$2 \mathrm{~b}$ Considering only the Technical Perspective to assess PV technologies, please compare the following criterion. Examples of criteria include: efficiency, technology maturity, production/operations, etc. Also refer to the worksheet "STEEP Criteria \& Factors" for the composition of each criterion.

\begin{tabular}{|c|c|c|}
\hline Efficiency & vs & Technology Maturity \\
\hline Efficiency & vs & Production/Operations \\
\hline Efficiency & vs & $\begin{array}{l}\text { Resources/Materials } \\
\text { Required }\end{array}$ \\
\hline Efficiency & vs & Deployment \\
\hline Efficiency & vs & Maintenance/Warranty \\
\hline Efficiency & vs & $\begin{array}{l}\text { Codes/Standards - } \\
\text { Compliance }\end{array}$ \\
\hline Efficiency & vs & Technology Roadmap \\
\hline Technology Maturity & vs & Production/Operations \\
\hline Technology Maturity & vs & $\begin{array}{l}\text { Resources/Materials } \\
\text { Required }\end{array}$ \\
\hline Technology Maturity & vs & Deployment \\
\hline Technology Maturity & vs & Maintenance/Warranty \\
\hline Technology Maturity & vs & $\begin{array}{l}\text { Codes/Standards - } \\
\text { Compliance }\end{array}$ \\
\hline Technology Maturity & vs & Technology Roadmap \\
\hline Production/Operations & vs & $\begin{array}{l}\text { Resources/Materials } \\
\text { Required }\end{array}$ \\
\hline Production/Operations & vs & Deployment \\
\hline Production/Operations & vs & Maintenance/Warranty \\
\hline Production/Operations & vs & $\begin{array}{l}\text { Codes/Standards - } \\
\text { Compliance }\end{array}$ \\
\hline Production/Operations & vs & Technology Roadmap \\
\hline Resources/Materials & vs & Deployment \\
\hline
\end{tabular}




\begin{tabular}{|c|c|c|}
\hline Required & & \\
\hline $\begin{array}{l}\text { Resources/Materials } \\
\text { Required }\end{array}$ & vs & Maintenance/Warranty \\
\hline $\begin{array}{l}\text { Resources/Materials } \\
\text { Required }\end{array}$ & vs & $\begin{array}{l}\text { Codes/Standards - } \\
\text { Compliance }\end{array}$ \\
\hline $\begin{array}{l}\text { Resources/Materials } \\
\text { Required }\end{array}$ & vs & Technology Roadmap \\
\hline Deployment & vs & Maintenance/Warranty \\
\hline Deployment & vs & $\begin{array}{l}\text { Codes/Standards - } \\
\text { Compliance }\end{array}$ \\
\hline Deployment & vs & Technology Roadmap \\
\hline Maintenance/Warranty & VS & $\begin{array}{l}\text { Codes/Standards - } \\
\text { Compliance }\end{array}$ \\
\hline Maintenance/Warranty & vs & Technology Roadmap \\
\hline $\begin{array}{l}\text { Codes/Standards - } \\
\text { Compliance }\end{array}$ & vs & Technology Roadmap \\
\hline
\end{tabular}

2c Considering only the Economic Perspective to assess PV technologies, please compare the following criteria. Examples, include product costs, levelized cost of energy, financial analysis, etc.

\begin{tabular}{|l|l|l|l|}
\hline Product Costs & vs & $\begin{array}{l}\text { LCOE (Levelized Cost of Energy) } \\
\text { - Electricity Generation Costs }\end{array}$ \\
\hline
\end{tabular}

\begin{tabular}{|l|l|l|l|l|}
\hline Product Costs & & vs & & Financial Analysis \\
\hline
\end{tabular}

\begin{tabular}{|c|c|c|}
\hline Product Costs & vs & Cost Mitigation \\
\hline Product Costs & vs & Market Adoption \\
\hline Product Costs & vs & $\begin{array}{l}\text { Positive Impact on Local } \\
\text { Economy }\end{array}$ \\
\hline
\end{tabular}

\begin{tabular}{|l|l|l|l|l|}
\hline $\begin{array}{l}\text { LCOE (Levelized Cost of } \\
\text { Energy) - Electricity } \\
\text { Generation Costs }\end{array}$ & & vs & & Financial Analysis \\
\hline
\end{tabular}




\begin{tabular}{|l|l|l|l|l|}
\hline $\begin{array}{l}\text { LCOE (Levelized Cost of } \\
\text { Energy) - Electricity } \\
\text { Generation Costs }\end{array}$ & vs & & Cost Mitigation \\
\hline
\end{tabular}

\begin{tabular}{|l|l|l|l|l|}
\hline $\begin{array}{l}\text { LCOE (Levelized Cost of } \\
\text { Energy) - Electricity } \\
\text { Generation Costs }\end{array}$ & vs & & Market Adoption \\
\hline
\end{tabular}

\begin{tabular}{|l|l|l|l|}
\hline $\begin{array}{l}\text { LCOE (Levelized Cost of } \\
\text { Energy) - Electricity } \\
\text { Generation Costs }\end{array}$ & vs & & $\begin{array}{l}\text { Positive Impact on Local } \\
\text { Economy }\end{array}$ \\
\hline
\end{tabular}

\begin{tabular}{|l|l|l|l|l|}
\hline Financial Analysis & & vs & & Cost Mitigation \\
\hline
\end{tabular}

\begin{tabular}{|l|l|l|l|l|}
\hline Financial Analysis & & vs & & Market Adoption \\
\hline
\end{tabular}

\begin{tabular}{|l|l|l|l|l|}
\hline Financial Analysis & & vs & & $\begin{array}{l}\text { Positive Impact on Local } \\
\text { Economy }\end{array}$ \\
\hline
\end{tabular}

\begin{tabular}{|c|c|c|}
\hline Cost Mitigation & vs & Market Adoption \\
\hline Cost Mitigation & vs & $\begin{array}{l}\text { Positive Impact on Local } \\
\text { Economy }\end{array}$ \\
\hline
\end{tabular}

\begin{tabular}{|l|l|l|l|l|}
\hline Market Adoption & & vs & & $\begin{array}{l}\text { Positive Impact on Local } \\
\text { Economy }\end{array}$ \\
\hline
\end{tabular}


2d Considering only the Environmental Perspective to assess PV technologies, please compare the following criteria. (Examples include pollution, positive impact, consumption of resources, etc.)

\begin{tabular}{|c|c|c|}
\hline Pollution/Negative Impact & vs & $\begin{array}{l}\text { Environmental } \\
\text { Benefits/Positive Impact }\end{array}$ \\
\hline Pollution/Negative Impact & vs & End-of-Life/Disposal \\
\hline Pollution/Negative Impact & vs & Consumption of Resources \\
\hline $\begin{array}{l}\text { Environmental } \\
\text { Benefits/Positive Impact }\end{array}$ & vs & End-of-Life/Disposal \\
\hline $\begin{array}{l}\text { Environmental } \\
\text { Benefits/Positive Impact }\end{array}$ & vs & Consumption of Resources \\
\hline End-of-Life/Disposal & vs & Consumption of Resources \\
\hline
\end{tabular}

2e Considering only the Political Perspective to assess PV technologies, please compare the following criteria. (Examples of criteria include: policies, regulation of power markets, public/government R\&D framework, etc.)

\begin{tabular}{|l|l|l|l|l|}
\hline Policies & vs & & $\begin{array}{l}\text { Regulation/Deregulation of } \\
\text { Power Markets }\end{array}$ \\
\hline Policies & & vs & $\begin{array}{l}\text { Public/Government R\&D } \\
\text { Framework }\end{array}$ \\
\hline
\end{tabular}

\begin{tabular}{|l|l|l|l|l|}
\hline Policies & & vs & & Codes/Standards - Compliance \\
\hline
\end{tabular}

\begin{tabular}{|l|l|l|l|l|}
\hline Policies & & vs & & Perception/Position of Utilities \\
\hline
\end{tabular}

\begin{tabular}{|l|l|l|l|l|}
\hline Policies & & vs & & Security \\
\hline
\end{tabular}

\begin{tabular}{|l|l|l|l|}
\hline $\begin{array}{l}\text { Regulation/Deregulation of } \\
\text { Power Markets }\end{array}$ & vs & & $\begin{array}{l}\text { Public/Government R\&D } \\
\text { Framework }\end{array}$ \\
\hline
\end{tabular}

\begin{tabular}{|l|l|l|l|l|}
\hline $\begin{array}{l}\text { Regulation/Deregulation of } \\
\text { Power Markets }\end{array}$ & vs & & Codes/Standards - Compliance \\
\hline
\end{tabular}

\begin{tabular}{|l|l|l|l|}
\hline $\begin{array}{l}\text { Regulation/Deregulation of } \\
\text { Power Markets }\end{array}$ & vs & & Perception/Position of Utilities \\
\hline
\end{tabular}




\begin{tabular}{|l|l|l|l|l|}
\hline $\begin{array}{l}\text { Regulation/Deregulation of } \\
\text { Power Markets }\end{array}$ & vs & & Security \\
\hline
\end{tabular}

\begin{tabular}{|l|l|l|l|l|}
\hline $\begin{array}{l}\text { Public/Government R\&D } \\
\text { Framework }\end{array}$ & vs & & Codes/Standards - Compliance \\
\hline
\end{tabular}

\begin{tabular}{|l|l|l|l|l|}
\hline $\begin{array}{l}\text { Public/Government R\&D } \\
\text { Framework }\end{array}$ & vs & & Perception/Position of Utilities \\
\hline
\end{tabular}

\begin{tabular}{|l|l|l|l|l|}
\hline $\begin{array}{l}\text { Public/Government R\&D } \\
\text { Framework }\end{array}$ & vs & & Security \\
\hline
\end{tabular}

\begin{tabular}{|c|c|c|}
\hline Codes/Standards - Compliance & vs & Perception/Position of Utilities \\
\hline
\end{tabular}

\begin{tabular}{|l}
\begin{tabular}{|l|l|l|l|l|}
\hline Codes/Standards - Compliance & & vs & & \multicolumn{1}{|l|}{ Security } \\
\hline Perception/Position of Utilities & & vs & & Security \\
\hline
\end{tabular}
\end{tabular}




\section{APPENDIX B: INITIAL MULTIPLE CRITERIA AND FACTORS FOR}

\section{STEEP PERSPECTIVES}

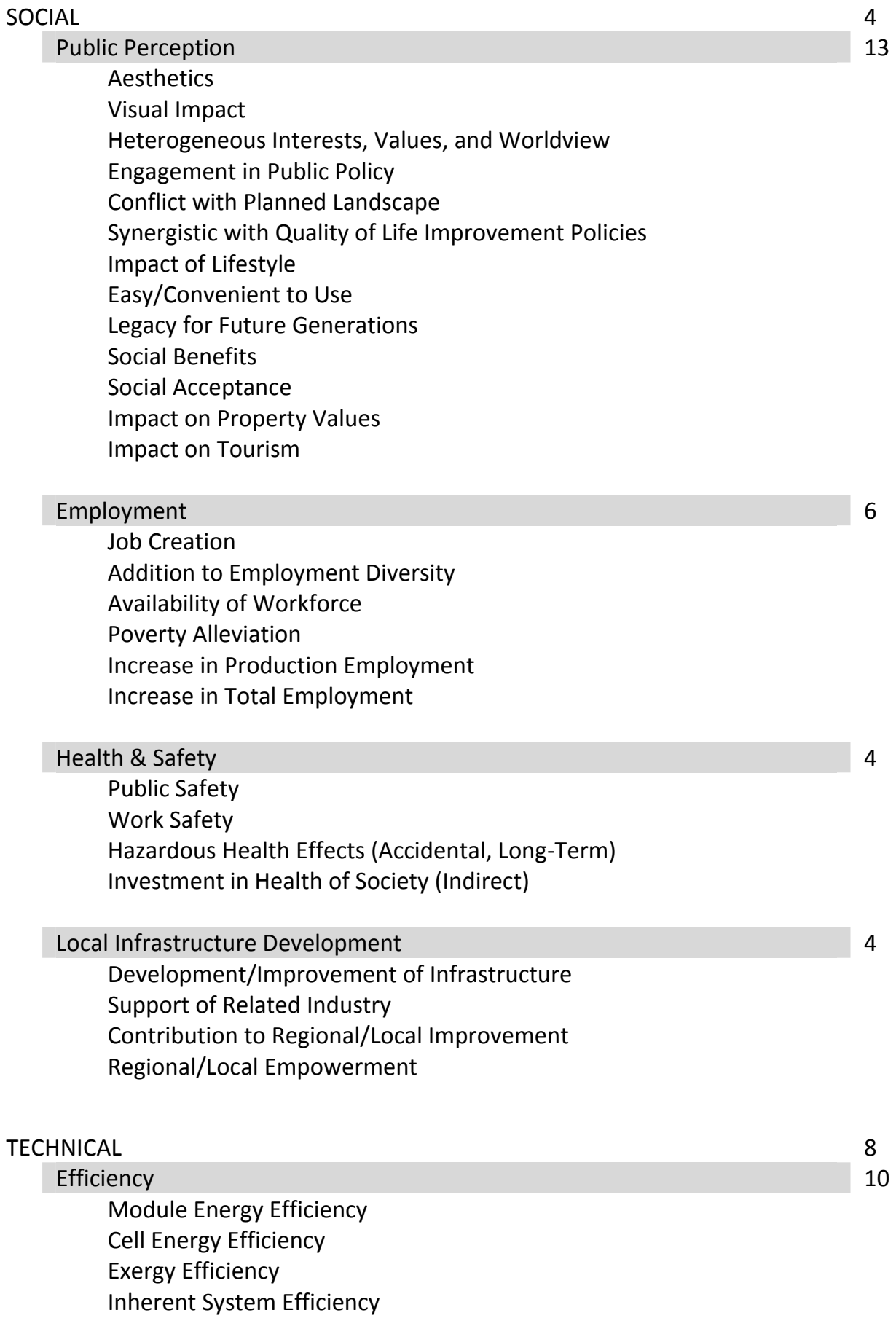


Thermal Efficiency

Heating Value

PV System Yield

Reference Yield

Performance Ratio

Energy Density

Technology Maturity

Density/Maturity of Patents \& Publications

Identify Positive Trends

Ability to Bridge Technology Gaps

Flexibility/Scalability

Modularity

Obsolescence Resistant

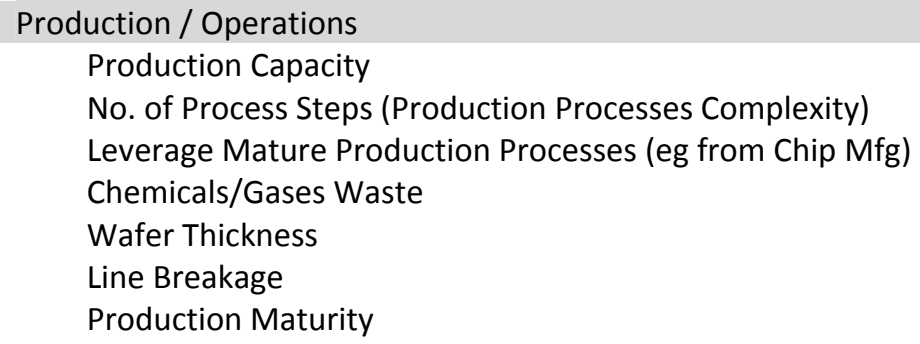

Avoid Hazardous Materials (eg Cadmium)

Resource Availability/Access

Chemicals, Gases, Etc.

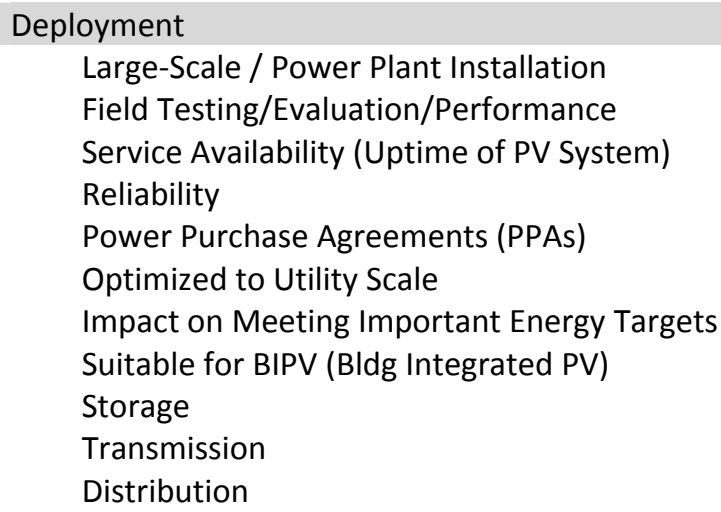

Low Maintenance

Long Lifetime (20+ years)

Annual Degradation Warranty

Management of Environmental Factors (Dust, Debris, etc.) 
National/International Standards

Building/Environmental Safety Standards

Technology Roadmap (2010-2030)

PV Technology (Cell/Module)

PV Technology Patents/Publications Maturity \& Trends

Inverter and BOS (Balance-of-System)

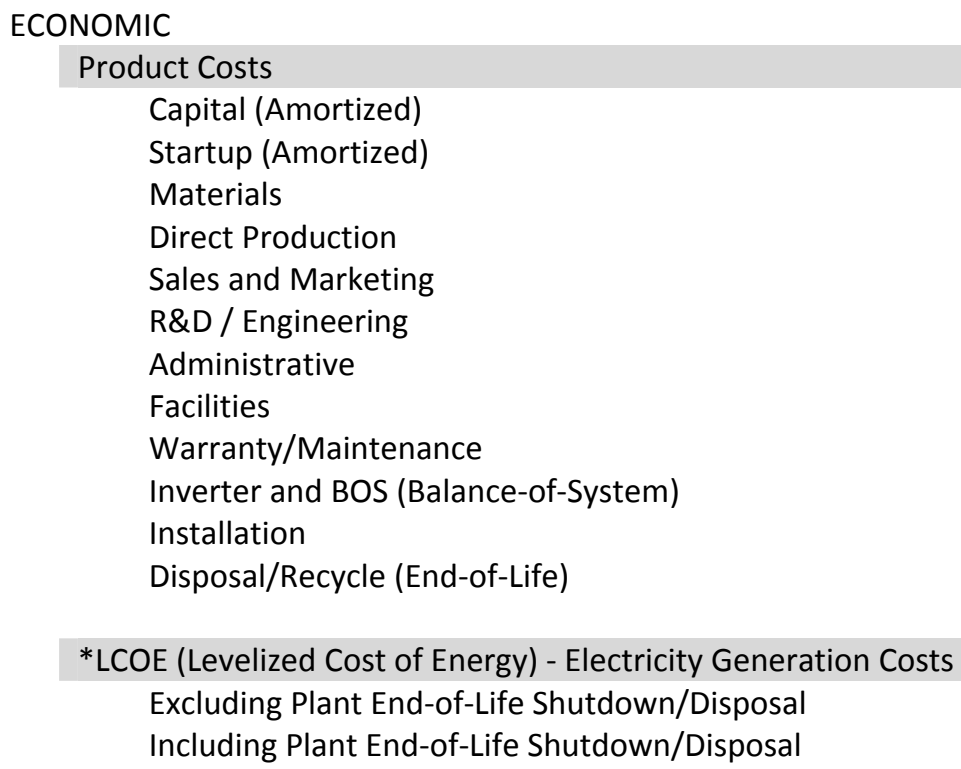

Capital (Amortized)

Startup (Amortized)

Materials

Direct Production

Sales and Marketing

$R \& D$ / Engineering

Administrative

Facilities

Warranty/Maintenance

Inverter and BOS (Balance-of-System)

Installation

Disposal/Recycle (End-of-Life)

* LCOE (Levelized Cost of Energy) - Electricity Generation Costs

Excluding Plant End-of-Life Shutdown/Disposal

Including Plant End-of-Life Shutdown/Disposal

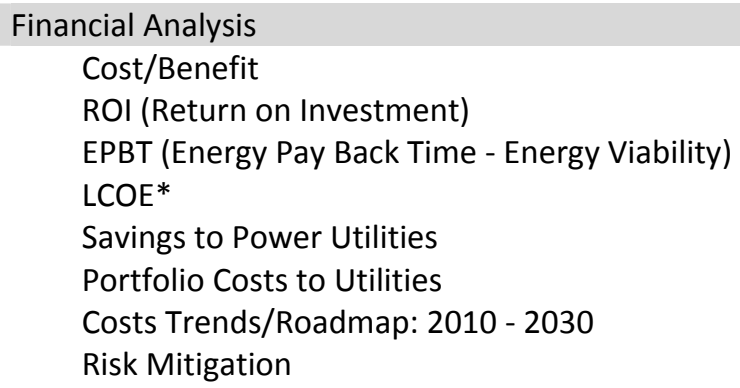

Independent of Economies of Scale

Energy Supply Chain Advantage (eg against fuels)

Reduction of Administrative Costs (eg against imports)

Reduction in Subsidies (of fuels)

Reduction in Military Costs (for energy)

Better Use of Hard Currency (for Developing Countries)

Market Adoption

Market Maturity

Product/Technology Maturity

Supply Chain Maturity

United States Code Compliance 
Economic Multiplier Effect (through use of product)

Customer Willingness to Pay

Positive Impact on Local Economy

Higher Wage Jobs

Creation/Expansion of Economic Clusters

Job Creation

Creating Insourcing Trend (Versus Outsourcing)

ENVIRONMENTAL

Pollution/Negative Impact

GHG (Green House Gases -Affecting Climate Change)

Particles (Smoke, Dust, etc.)

Vapor

Visual / Glare

Water

Noise

Solid Waste

Water Resources

Stratospheric Ozone

Soil

Natural Habitat

Water Temperature Change

Wind Pattern Change

Forest and Ecosystem

Ecological Footprint (Crops, Woods, etc.)

During Production Phase

During Deployment Phase

Accidental Release of Chemicals

Environmental Benefits/Positive Impact

8

Better Land Utilization

Climate Change Mitigation

Environment Sustainability

Low Land Requirement

Energy Conservation Improvement

Better Consumption of Natural Resources

Reduced Fossil Fuel Imports/Dependence

Better Use of Rooftops

End-of-Life/Disposal

Biodegradability

Easy Recyclability

Leverage Mature Production Processes (e.g. from Chip Mfg)

Chemicals/Gases Waste

Consumption of Resources

Land

Water

Materials 
Security

Support for Renewable Energy / Energy Efficiency

National Energy Independence

Financing Options / Government Backing

Local Sourcing

5-10 year Plans for Renewable Energy / Energy Efficiency

Workforce Training

Integration/Replacement of Existing Power Plants

Regulation/Deregulation of Power Markets

9

RPS (Renewable Portfolio Standard)

FIT (Feed-In Tariffs)

Net-Metering

Incentives

Energy Price Controls / Rate Structure

Subsidies (Tax Credits, Tax Exemptions, etc.)

Carbon Tax

Cap and Trade

Centralized/Decentralized Power

Public/Government R\&D Framework

Government Labs R\&D

Technology Transfer

Strategic Technology Plan/Roadmap

Codes/Standards - Compliance

United States Code

National/International Standards

Building/Environmental Safety Standards

Perception/Position of Utilities

Conformance to Existing Political, Legal, Management Constructs

Dirty Fuels Lobbies

Security

Energy Supply Stability

Energy Price Stability 


\section{APPENDIX C: STEEP DECISION MODEL CRITERIA VALIDATION}

\section{INSTRUMENT}

(This instrument is exported from online Qualtrics format to Microsoft Word format for inclusion here.)

\section{STEEP Decision Model Criteria Validation}

Q1 STEEP Decision Model Criteria Validation

The objective of this instrument is to finalize the list of criteria that should be used for each of the five social, technical, economic, and political (STEEP) perspectives to evaluate photovoltaic technologies from the viewpoint of electric utilities. Please indicate below by clicking "Yes" or "No" for each criterion, whether or not it should be included. Also please add additional criteria you consider important or your comments.

Q2 Please select your area of expertise. Multiple perspectives may be selected.

口 Social Perspective (1)

Technical Perspective (2)

- Economic Perspective (3)

- Environmental Perspective (4)

口 Political Perspective (5)

Answer If Social Perspective Is Selected

Q3 Social Perspective: Criteria

Job Creation Job creation is a top priority for many communities. Certain PV technologies may be produced locally within the utility's service area. Jobs are created for production, installation, and operations. (1)

Health Effects - During Production Phase Long-term negative health effects. (2) Health Effects - During Operations Phase Long-term negative health effects. (3) Additional Criteria or Comments (4)

Answer If Technical Perspective Is Selected

Q4 Technical Perspective: Criteria

Module Energy Efficiency PV Module or Panel Efficiency (\%) - percentage of light energy that hits the module and gets converted into electricity. A $1 \mathrm{~m} \times 1.5 \mathrm{~m}$ module or panel made of $20 \%$ efficient cells would receive $1.5 \mathrm{~kW}$ of energy from the sun and convert it to a 300 watt output. (1)

Power Density The energy density of a solar module is the efficiency described in terms of peak power output per unit of surface area in W/ft2 or W/m2. Highefficiency PV panels have energy densities greater than $13 \mathrm{~W} / \mathrm{ft} 2$ or $140 \mathrm{~W} / \mathrm{m} 2$. (2) Module Durability Durability can be defined as avoidance of loss of desirable properties resulting in declining performance and shortened service lifetime. PV durability is environmental durability and is a measure of the retention of original condition and function of a material after exposure to weather conditions. A PV module is considered to be durable if it maintains at least $80 \%$ of its original performance after 25 years. (3) Module Reliability Module reliability is the module's performance of its intended function during its lifetime. Reliability measure relates to absolute failures. (4)

Yes (1) No (2)

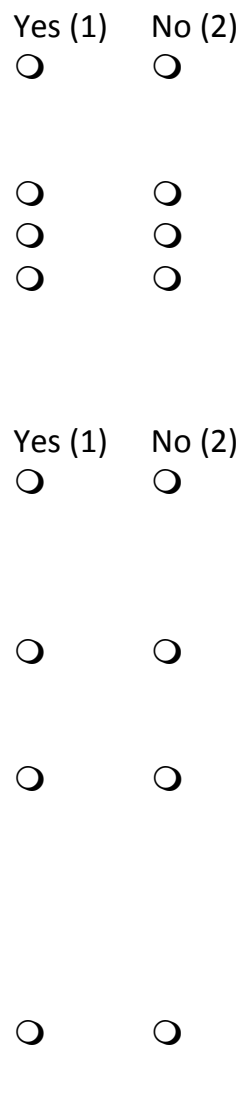


Global Production/Supply Volume Global production volume can affect price, supply, and timely replacement of PV panels and systems. (5)

Use of Rare Elements (e.g. Indium, Tellurium) Using rare element materials may be an issue due to their scarcity and restrictive access. (6) Use of Hazardous Materials (e.g. Cadmium) Using hazardous materials may be an issue if there is accidental leakage or contact with humans or animals. (7) State of Power Plant Installation Worldwide Is this PV technology deployed by electric utilities anywhere in the world? (8)

State of Field Performance How long has this PV technology been field tested? (9) Maintenance Required The level of maintenance required to ensure that PV module is in proper working condition. (10)

Life of PV Panel This represents the duration of useful life of the PV module. (11) Additional Criteria or Comments (12)

Answer If Economic Perspective Is Selected Q5 Economic Perspective: Criteria

Total Purchase Cost of PV Panels to Utility In volume purchase the current price of crystalline silicon-based PV panels is about \$1 - 2/W (2012). (1) Warranty/Maintenance Cost Warranty may vary from 10 to 25 years with varying performance levels. To maintain the systems at peak performance level the utility needs in-house or contracted maintenance. (2)

Total Associated Inverter and Balance-of-System Purchase Cost The Balance-ofSystem (BOS) includes everything beyond the PV module for a solar system such as the inverter(s) (or micro-inverters), the electrical system, and the structural system for mounting. In volume purchase the current price of crystalline silicon-based PV BOS is about $\$ 1.5$ - 3/W (2012). (3)

Disposal Cost This is the disposal cost at end of life of a PV panel. A typical siliconbased PV panel cost of disposal is estimated to be about $\$ 0.60$ for a $200 \mathrm{~W}$ panel. (4) Levelized Cost of Electricity (LCOE) The levelized cost of electricity (LCOE) is considered the most important metric for renewable energy utility systems. It is also referred to as "levelized cost of energy." LCOE is the price at which electricity must be generated from an energy source to break even over the utility system lifetime. It typically includes all the lifetime investment costs, capitals costs, operations costs, and disposal costs. A scalable PV design capable of achieving LCOE under $\$ 0.10 / \mathrm{kWh}$ unsubsidized becomes cheaper than retail electricity in many U.S. markets. Currently LCOE varies greatly and may range from $\$ 0.15 / \mathrm{kWh}$ to higher values. (5)

Return on Investment Lifetime return on investment based on internal rate of return (IRR). (6)

Risk Assessment This is the cost of risk in using PV system as electric utility. Risk may

Yes (1) No (2)

$\mathrm{O}$

$\mathrm{O}$ include cost of downtime/maintenance and the cleanup of negative environmental impact during operations such as leakage of hazardous materials. (7)

Supply Chain Maturity Distribution and Supply Chain is important for the buyer of PV panels and associated balance of systems. The maturity levels of the supply chain may vary from "ad hoc" where practices are unstructured to "extended" where multiple firms compete for business. The following defines the supply chain levels:

Extended - Firms at the extended level have multiple supply chains competing for the business and working together with a customer focus. This is the highest level of supply chain maturity.

Integrated - At this level supply chain management systems are integrated and well 
defined. Production planning and forecasting are established. Established firms are typically at this level.

Linked - The linked level sets the supply chain on a strategic path by enabling stronger relationships between partners and defined structures and roles.

Defined - At this level firms are developing supply chain supply chain relationships and have management processes. Supply chain performance, management costs, and customer satisfaction is improving. However, lack of integration makes cooperation between supply chain members difficult.

Ad Hoc - The ad hoc level or stage is usually associated with start-ups with unstructured management practices and no measurement processes established.

This typically results in unpredictable supply chain performance, higher management costs, and low customer satisfaction. This is the lowest level of supply chain

maturity. (8)

Additional Criteria or Comments (9)

Answer If Environmental Perspective Is Selected

Q6 Environmental Perspective: Criteria

Emission of Greenhouse Gases During Production Governments are encouraging sustainability and are restricting greenhouse gas (GHG) emissions such CO2, NOx, and SOx. In the future utilities may consider this as a factor for evaluation of PV technologies. (1)

Negative Ecological Footprint How much of a negative impact does the deployment of a PV technology have on the underlying and surrounding crops, woods, etc.? (2) Use of Available Land In many parts of the world land is a scarce resource and better utilization by a PV technology is a consideration. (3)

Recyclability at End-of-Life Disposal of PV systems at the end-of-life are more attractive if the component materials can be easily recycled. (4)

Waste Chemicals at End-of-Life Waste chemicals may be released by the disposal of PV systems and hence these must be disposed of according to governing

regulations. This would incur higher costs. (5)

Waste Gases at End-of-Life Waste gases may be released by the disposal of PV systems and hence these must be disposed of according to governing regulations. This would incur higher costs. (6)

Water Consumption During Operations Water consumption may be required for cooling or cleaning of PV technologies during operations. (7)

Consumption of Other Materials During Operations Other materials may be

consumed during operations. (8)

Additional Criteria or Comments (9)

Answer If Political Perspective Is Selected

Q7 Political Perspective: Criteria

Government Backing Government support through financing, incentives, preferences, and general backing can affect the selection of a PV technology. (1) Local Sourcing Certain countries (e.g. Canada) require partial local sourcing of renewable energy equipment for feed-in tariffs to be applicable. (2)

Conformance to Existing Political, Legal, Management Constructs by Utilities Utilities are accustomed to established business or regulatory practices and change is difficult. (3)

Additional Criteria or Comments (4)

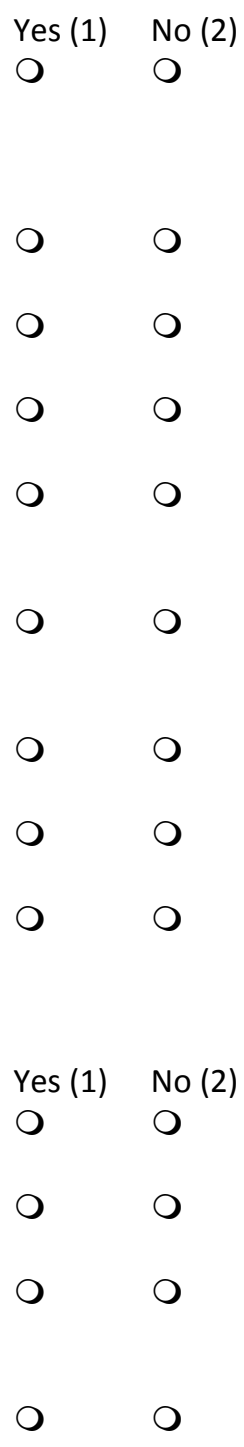




\section{APPENDIX D: STEEP DESIRABILITY FUNCTIONS INSTRUMENT}

The results for arithmetic mean of the criteria desirability values for measurement scales have been added to the instrument.

\begin{tabular}{|c|c|c|c|c|c|c|}
\hline & \multirow{2}{*}{$\begin{array}{l}\text { Perspective } \\
\text { SOCIAL (4) }\end{array}$} & Criteria & \multirow[t]{2}{*}{ Description } & \multicolumn{3}{|c|}{ Measurement Scale (High to Low Desirability) } \\
\hline & & & & \\
\hline \multirow[t]{7}{*}{1.} & & \multirow[t]{7}{*}{ S1: Job Creation } & \multirow{7}{*}{$\begin{array}{l}\text { Job creation is a top priority for many } \\
\text { communities. Certain PV technologies may } \\
\text { be produced locally within the utility's } \\
\text { service area. Jobs are created for } \\
\text { production, installation, and operations. }\end{array}$} & \multicolumn{3}{|c|}{ No. of jobs created in the community by this technology } \\
\hline & & & & $\begin{array}{l}\text { Desirab. } \\
\text { Value }\end{array}$ & $\begin{array}{l}\text { Criterion } \\
\text { Measure }\end{array}$ & $\begin{array}{l}\text { Criterion Measure Description } \\
\text { (if Needed) }\end{array}$ \\
\hline & & & & 100 & $>300$ & Greater than 300 jobs created. \\
\hline & & & & 92 & $101-300$ & $100-300$ jobs created. \\
\hline & & & & 75 & $25-100$ & $25-100$ jobs created. \\
\hline & & & & 43 & $1-24$ & $1-24$ jobs created. \\
\hline & & & & 0 & 0 & No jobs created. \\
\hline \multirow[t]{8}{*}{2.} & & \multirow{8}{*}{$\begin{array}{l}\text { S2: Health } \\
\text { Effects - During } \\
\text { Production } \\
\text { Phase }\end{array}$} & \multirow[t]{8}{*}{ Negative health effects. } & & & \\
\hline & & & & $\begin{array}{l}\text { Desirab. } \\
\text { Value }\end{array}$ & $\begin{array}{l}\text { Criterion } \\
\text { Measure }\end{array}$ & $\begin{array}{l}\text { Criterion Measure Description } \\
\text { (if Needed) }\end{array}$ \\
\hline & & & & 100 & None & No negative health effects. \\
\hline & & & & 79 & Very low & $\begin{array}{l}\text { Could cause no disability but } \\
\text { minor inconvenience. }\end{array}$ \\
\hline & & & & 59 & Low & $\begin{array}{l}\text { Could cause minor temporary } \\
\text { disability. }\end{array}$ \\
\hline & & & & 13 & Medium & $\begin{array}{l}\text { Could cause significant but } \\
\text { temporary disability. }\end{array}$ \\
\hline & & & & 1 & High & $\begin{array}{l}\text { Could cause permanent disability } \\
\text { but fatality not likely. }\end{array}$ \\
\hline & & & & 0 & Very high & Could cause fatality. \\
\hline
\end{tabular}




\begin{tabular}{|c|c|c|c|c|c|}
\hline & \multirow{8}{*}{$\begin{array}{l}\text { S3: Health } \\
\text { Effects - During } \\
\text { Operations } \\
\text { Phase }\end{array}$} & \multirow{8}{*}{ Negative health effects. } & & & \\
\hline \multirow[t]{7}{*}{3.} & & & $\begin{array}{l}\text { Desirab. } \\
\text { Value }\end{array}$ & $\begin{array}{l}\text { Criterion } \\
\text { Measure }\end{array}$ & $\begin{array}{l}\text { Criterion Measure Description } \\
\text { (if Needed) }\end{array}$ \\
\hline & & & 100 & None & No negative health effects. \\
\hline & & & 79 & Very low & $\begin{array}{l}\text { Could cause no disability but } \\
\text { minor inconvenience. }\end{array}$ \\
\hline & & & 52 & Low & $\begin{array}{l}\text { Could cause minor temporary } \\
\text { disability. }\end{array}$ \\
\hline & & & 11 & Medium & $\begin{array}{l}\text { Could cause significant but } \\
\text { temporary disability. }\end{array}$ \\
\hline & & & 1 & High & $\begin{array}{l}\text { Could cause permanent disability } \\
\text { but fatality not likely. }\end{array}$ \\
\hline & & & 0 & Very high & Could cause fatality. \\
\hline \multirow[t]{6}{*}{4.} & \multirow{6}{*}{$\begin{array}{l}\text { S4: Negative } \\
\text { Publicity }\end{array}$} & \multirow{6}{*}{$\begin{array}{l}\text { Bad publicity associated with the specific } \\
\text { PV technology. }\end{array}$} & & & \\
\hline & & & $\begin{array}{l}\text { Desirab. } \\
\text { Value }\end{array}$ & $\begin{array}{l}\text { Criterion } \\
\text { Measure }\end{array}$ & $\begin{array}{l}\text { Criterion Measure Description } \\
\text { (if Needed) }\end{array}$ \\
\hline & & & 100 & None & No negative publicity at all. \\
\hline & & & 86 & Very low & $\begin{array}{l}\text { Nominal negative publicity that } \\
\text { does not impact technology } \\
\text { deployment but caution should } \\
\text { be exercised in case this has the } \\
\text { potential to escalate to low } \\
\text { negative publicity. }\end{array}$ \\
\hline & & & 68 & Low & $\begin{array}{l}\text { Low negative publicity that may } \\
\text { have some impact on technology } \\
\text { deployment. This may be } \\
\text { through the news, social media, } \\
\text { or interest groups. }\end{array}$ \\
\hline & & & 15 & Medium & $\begin{array}{l}\text { Medium level of negative } \\
\text { publicity that can have on impact } \\
\text { on technology deployment and } \\
\text { corrective actions are necessary. } \\
\text { This may be through the news, } \\
\text { social media, interest groups, }\end{array}$ \\
\hline
\end{tabular}




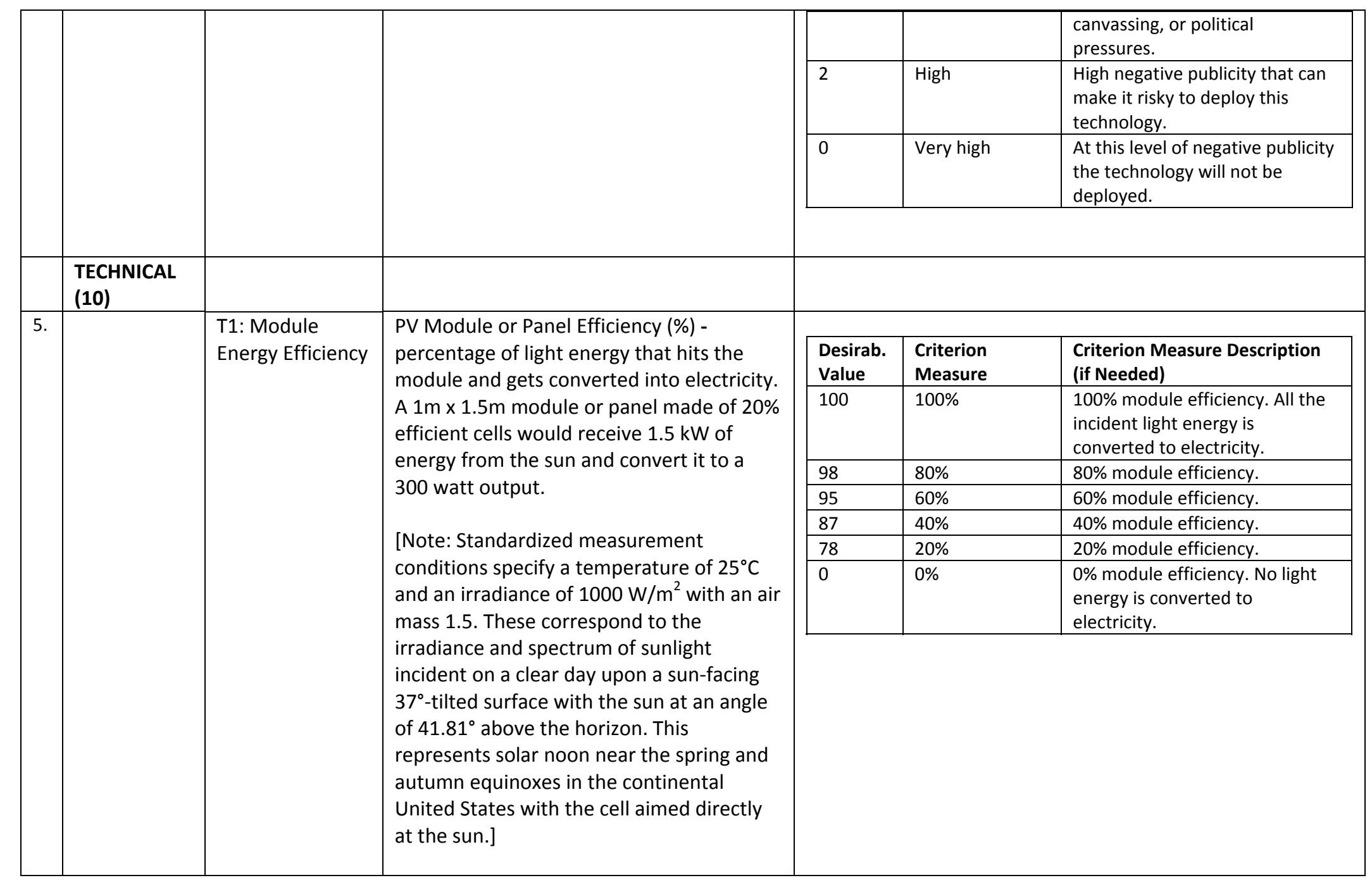




\begin{tabular}{|c|c|c|c|c|c|}
\hline \multirow[t]{7}{*}{6.} & \multirow[t]{7}{*}{$\begin{array}{l}\text { T2: Power } \\
\text { Density }\end{array}$} & \multirow{7}{*}{$\begin{array}{l}\text { The power density of a PV module or panel } \\
\text { is the efficiency described in terms of peak } \\
\text { power output per unit of surface area in } \\
\mathrm{W} / \mathrm{ft}^{2} \text { or } \mathrm{W} / \mathrm{m}^{2} \text {. High-efficiency PV panels } \\
\text { have energy densities greater than } 13 \\
\mathrm{~W} / \mathrm{ft}^{2} \text { or } 140 \mathrm{~W} / \mathrm{m}^{2} \text {. }\end{array}$} & $\begin{array}{l}\text { Desirab. } \\
\text { Value }\end{array}$ & $\begin{array}{l}\text { Criterion } \\
\text { Measure }\end{array}$ & $\begin{array}{l}\text { Criterion Measure Description } \\
\text { (if Needed) }\end{array}$ \\
\hline & & & 100 & $>200 \mathrm{~W} / \mathrm{m}^{2}$ & \\
\hline & & & 95 & $151-200 \mathrm{~W} / \mathrm{m}^{2}$ & \\
\hline & & & 81 & $101-150 \mathrm{~W} / \mathrm{m}^{2}$ & \\
\hline & & & 39 & $51-100 \mathrm{~W} / \mathrm{m}^{2}$ & \\
\hline & & & 15 & $1-50 \mathrm{~W} / \mathrm{m}^{2}$ & \\
\hline & & & 0 & 0 & \\
\hline \multirow[t]{11}{*}{7.} & \multirow[t]{11}{*}{$\begin{array}{l}\text { T3: Module } \\
\text { Durability }\end{array}$} & \multirow{11}{*}{$\begin{array}{l}\text { Durability can be defined as avoidance of } \\
\text { loss of desirable properties resulting in } \\
\text { declining performance and shortened } \\
\text { service lifetime. PV durability is } \\
\text { environmental durability and is a measure } \\
\text { of the retention of original condition and } \\
\text { function of a material after exposure to } \\
\text { weather conditions. A PV module is } \\
\text { considered to be durable if it maintains at } \\
\text { least } 80 \% \text { of its original performance after } \\
25 \text { years. }\end{array}$} & \multicolumn{3}{|c|}{$\begin{array}{l}\text { After } 25 \text { years maintains the following performance levels (as } \\
\text { compared to the original performance level) }\end{array}$} \\
\hline & & & $\begin{array}{l}\text { Desirab. } \\
\text { Value }\end{array}$ & $\begin{array}{l}\text { Criterion } \\
\text { Measure }\end{array}$ & $\begin{array}{l}\text { Criterion Measure Description } \\
\text { (if Needed) }\end{array}$ \\
\hline & & & 100 & $91-100 \%$ & \\
\hline & & & 90 & $81-90 \%$ & \\
\hline & & & 73 & $71-80 \%$ & \\
\hline & & & $\frac{44}{25}$ & $61-70 \%$ & \\
\hline & & & 13 & $41-50 \%$ & \\
\hline & & & 8 & $31-40 \%$ & \\
\hline & & & 2 & $21-30 \%$ & \\
\hline & & & 1 & $10-20 \%$ & \\
\hline & & & 0 & $<10 \%$ & \\
\hline \multirow[t]{5}{*}{8.} & \multirow{5}{*}{$\begin{array}{l}\text { T4: Module } \\
\text { Reliability }\end{array}$} & \multirow{5}{*}{$\begin{array}{l}\text { Module reliability is the module's } \\
\text { performance of its intended function } \\
\text { during its lifetime. Reliability measure } \\
\text { relates to absolute failures. }\end{array}$} & \multicolumn{3}{|c|}{ Percent of the modules that fail during their lifetime } \\
\hline & & & $\begin{array}{l}\text { Desirab. } \\
\text { Value }\end{array}$ & $\begin{array}{l}\text { Criterion } \\
\text { Measure }\end{array}$ & $\begin{array}{l}\text { Criterion Measure Description } \\
\text { (if Needed) }\end{array}$ \\
\hline & & & 100 & $<1 \%$ & \\
\hline & & & 72 & $1-5 \%$ & \\
\hline & & & 38 & $6-10 \%$ & \\
\hline
\end{tabular}




\begin{tabular}{|c|c|c|c|c|c|}
\hline & & & 17 & $11-15 \%$ & \\
\hline & & & 2 & $16-20 \%$ & \\
\hline & & & 0 & $21-25 \%$ & \\
\hline & & & 0 & $26-30 \%$ & \\
\hline & & & 0 & $31-35 \%$ & \\
\hline & & & 0 & $36-40 \%$ & \\
\hline & & & 0 & $41-45 \%$ & \\
\hline & & & 0 & $>45 \%$ & \\
\hline \multirow[t]{8}{*}{9.} & \multirow{8}{*}{$\begin{array}{l}\text { T5: Potential } \\
\text { Induced } \\
\text { Degradation } \\
\text { (PID) } \\
\text { Performance }\end{array}$} & \multirow{8}{*}{$\begin{array}{l}\text { PID has become a major concern in the } \\
\text { solar industry as it can significantly reduce } \\
\text { the power output of a PV system. Inherent } \\
\text { differences in voltage between the module } \\
\text { framework and solar cells as well as } \\
\text { environmental conditions such as } \\
\text { increased humidity and higher } \\
\text { temperatures can lead to degradation over } \\
\text { the life cycle of the module. This reduces } \\
\text { the yield of a PV system. } \\
\text { [During the tests performed by TUV } \\
\text { Rheinland and PV Lab, a negative voltage } \\
\text { of } 1,000 \text { Volts is applied to the modules at } \\
\text { an ambient room temperature ( } 25 \text { degrees } \\
\text { Celsius) and humidity over a period of } 7 \\
\text { days (168 hours). The module front is } \\
\text { covered with aluminum foil or a constant } \\
\text { water film to minimize the resistivity with } \\
\text { the grounded frame. According to both } \\
\text { laboratories, if a module's performance } \\
\text { declines by less than five percent under } \\
\text { test conditions it is deemed to have passed } \\
\text { the test.] }\end{array}$} & \multicolumn{3}{|c|}{$\begin{array}{l}\text { Effect of PID testing on performance levels (as compared to the } \\
\text { original performance level) }\end{array}$} \\
\hline & & & $\begin{array}{l}\text { Desirab. } \\
\text { Value }\end{array}$ & $\begin{array}{l}\text { Criterion } \\
\text { Measure }\end{array}$ & $\begin{array}{l}\text { Criterion Measure Description } \\
\text { (if Needed) }\end{array}$ \\
\hline & & & 100 & $<5 \%$ & \\
\hline & & & 74 & $5-10 \%$ & \\
\hline & & & 51 & $11-15 \%$ & \\
\hline & & & 28 & $16-20 \%$ & \\
\hline & & & 6 & $21-25 \%$ & \\
\hline & & & & & \\
\hline
\end{tabular}




\begin{tabular}{|c|c|c|c|c|c|}
\hline \multirow[t]{7}{*}{10.} & \multirow[t]{7}{*}{$\begin{array}{l}\text { T6: PV Module } \\
\text { Design Flexibility }\end{array}$} & \multirow[t]{7}{*}{$\begin{array}{l}\text { PV module or panel geometries and other } \\
\text { design considerations may be important } \\
\text { for location-based deployments. }\end{array}$} & $\begin{array}{l}\text { Desirab. } \\
\text { Value }\end{array}$ & $\begin{array}{l}\text { Criterion } \\
\text { Measure }\end{array}$ & $\begin{array}{l}\begin{array}{l}\text { Criterion Measure Description } \\
\text { (if Needed) }\end{array} \\
\end{array}$ \\
\hline & & & 100 & Very high & $\begin{array}{l}\text { This PV module can be } \\
\text { configured to fit any building or } \\
\text { landscape contour or location } \\
\text { requirements. }\end{array}$ \\
\hline & & & 91 & High & $\begin{array}{l}\text { PV module can be configured to } \\
\text { fit } 80 \% \text { of building or landscape } \\
\text { contour or location } \\
\text { requirements. }\end{array}$ \\
\hline & & & 75 & Medium & $\begin{array}{l}\text { PV module can be configured to } \\
\text { fit } 60 \% \text { of the building or } \\
\text { landscape contour or location } \\
\text { requirements. }\end{array}$ \\
\hline & & & 56 & Low & $\begin{array}{l}\text { PV module can be configured to } \\
\text { fit } 40 \% \text { of the building or } \\
\text { landscape contour or location } \\
\text { requirements. }\end{array}$ \\
\hline & & & 33 & Very low & $\begin{array}{l}\text { PV module can be configured to } \\
\text { fit } 20 \% \text { of the building or } \\
\text { landscape contour or location } \\
\text { requirements. }\end{array}$ \\
\hline & & & 15 & None & $\begin{array}{l}\text { PV module cannot be configured } \\
\text { to fit any building or landscape } \\
\text { contour or location } \\
\text { requirements. }\end{array}$ \\
\hline \multirow[t]{4}{*}{11.} & \multirow{4}{*}{$\begin{array}{l}\text { T7: State of } \\
\text { Power Plant } \\
\text { Installation } \\
\text { Worldwide }\end{array}$} & \multirow{4}{*}{$\begin{array}{l}\text { Is this PV technology deployed by electric } \\
\text { utilities anywhere in the world? Electric } \\
\text { utilities prefer to use technologies that } \\
\text { have been proven in similar applications. }\end{array}$} & & & \\
\hline & & & $\begin{array}{l}\text { Desirab. } \\
\text { Value }\end{array}$ & $\begin{array}{l}\text { Criterion } \\
\text { Measure }\end{array}$ & $\begin{array}{l}\text { Criterion Measure Description } \\
\text { (if Needed) }\end{array}$ \\
\hline & & & 100 & $\begin{array}{l}\text { Heavily } \\
\text { deployed }\end{array}$ & $\begin{array}{l}\text { PV technology is commonly } \\
\text { deployed by electric utilities } \\
\text { worldwide. }\end{array}$ \\
\hline & & & 83 & Beginning to be & PV technology is gaining \\
\hline
\end{tabular}




\begin{tabular}{|c|c|c|c|c|c|}
\hline & & & & $\begin{array}{l}\text { heavily } \\
\text { deployed }\end{array}$ & $\begin{array}{l}\text { popularity and is beginning to be } \\
\text { heavily deployed by electric } \\
\text { utilities worldwide. }\end{array}$ \\
\hline & & & 40 & $\begin{array}{l}\text { Sparsely } \\
\text { deployed }\end{array}$ & $\begin{array}{l}\text { PV technology is not common } \\
\text { and is sparsely deployed by } \\
\text { electric utilities worldwide. }\end{array}$ \\
\hline & & & 0 & Not deployed & $\begin{array}{l}\text { PV technology is not deployed at } \\
\text { all by electric utilities worldwide. }\end{array}$ \\
\hline \multirow[t]{7}{*}{12.} & \multirow{7}{*}{$\begin{array}{l}\text { T8: State of Field } \\
\text { Performance }\end{array}$} & \multirow{7}{*}{$\begin{array}{l}\text { How long has this PV technology been field } \\
\text { tested? }\end{array}$} & & & \\
\hline & & & $\begin{array}{l}\text { Desirab. } \\
\text { Value }\end{array}$ & $\begin{array}{l}\text { Criterion } \\
\text { Measure }\end{array}$ & $\begin{array}{l}\text { Criterion Measure Description } \\
\text { (if Needed) }\end{array}$ \\
\hline & & & 100 & $\begin{array}{l}\text { Tested for more } \\
\text { than } 10 \text { years }\end{array}$ & $\begin{array}{l}\text { PV technology has been } \\
\text { deployed and field tested for } \\
\text { more than } 10 \text { years. }\end{array}$ \\
\hline & & & 88 & $\begin{array}{l}\text { Tested between } \\
5-10 \text { years }\end{array}$ & $\begin{array}{l}\text { PV technology has been } \\
\text { deployed and field tested } \\
\text { between } 5 \text { and } 10 \text { years. }\end{array}$ \\
\hline & & & 52 & $\begin{array}{l}\text { Tested between } \\
1-5 \text { years }\end{array}$ & $\begin{array}{l}\text { PV technology has been } \\
\text { deployed and field tested } \\
\text { between } 1 \text { and } 5 \text { years. }\end{array}$ \\
\hline & & & 12 & Testing initiated & $\begin{array}{l}\text { PV technology has not been } \\
\text { deployed and field testing has } \\
\text { just started. }\end{array}$ \\
\hline & & & 0 & Not tested & $\begin{array}{l}\text { No field testing has been done } \\
\text { on this PV technology. }\end{array}$ \\
\hline \multirow[t]{4}{*}{13.} & \multirow{4}{*}{$\begin{array}{l}\text { T9: Maintenance } \\
\text { Required }\end{array}$} & \multirow{4}{*}{$\begin{array}{l}\text { The level of maintenance required to } \\
\text { ensure that } \mathrm{PV} \text { module is in proper } \\
\text { working condition. }\end{array}$} & & & \\
\hline & & & $\begin{array}{l}\text { Desirab. } \\
\text { Value }\end{array}$ & $\begin{array}{l}\text { Criterion } \\
\text { Measure }\end{array}$ & $\begin{array}{l}\text { Criterion Measure Description } \\
\text { (if Needed) }\end{array}$ \\
\hline & & & 100 & $\begin{array}{l}\text { No Maintenance } \\
\text { needed }\end{array}$ & $\begin{array}{l}\text { No maintenance is required to } \\
\text { ensure that the PV module is in } \\
\text { proper working condition. }\end{array}$ \\
\hline & & & 78 & $\begin{array}{l}\text { Yearly } \\
\text { Maintenance }\end{array}$ & $\begin{array}{l}\text { Yearly maintenance is required } \\
\text { to ensure that the PV module is }\end{array}$ \\
\hline
\end{tabular}




\begin{tabular}{|c|c|c|c|c|c|c|}
\hline & & & & & needed & in proper working condition. \\
\hline & & & & 35 & $\begin{array}{l}\text { Monthly } \\
\text { Maintenance } \\
\text { needed }\end{array}$ & $\begin{array}{l}\text { Monthly maintenance is } \\
\text { required to ensure that the PV } \\
\text { module is in proper working } \\
\text { condition. }\end{array}$ \\
\hline & & & & 12 & $\begin{array}{l}\text { Weekly } \\
\text { Maintenance } \\
\text { needed }\end{array}$ & $\begin{array}{l}\text { Weekly maintenance is required } \\
\text { to ensure that the PV module is } \\
\text { in proper working condition. }\end{array}$ \\
\hline & & & & 0 & $\begin{array}{l}\text { Constant } \\
\text { Maintenance } \\
\text { needed }\end{array}$ & $\begin{array}{l}\text { Constant maintenance is } \\
\text { required to ensure that the PV } \\
\text { module is in proper working } \\
\text { condition. }\end{array}$ \\
\hline \multirow[t]{9}{*}{14.} & & \multirow{8}{*}{$\begin{array}{l}\text { T10: Life of PV } \\
\text { Panel }\end{array}$} & \multirow{8}{*}{$\begin{array}{l}\text { This represents the duration of useful life } \\
\text { of the } P V \text { module. }\end{array}$} & & & \\
\hline & & & & $\begin{array}{l}\text { Desirab. } \\
\text { Value }\end{array}$ & $\begin{array}{l}\text { Criterion } \\
\text { Measure }\end{array}$ & $\begin{array}{l}\text { Criterion Measure Description } \\
\text { (if Needed) }\end{array}$ \\
\hline & & & & 100 & $>50$ years & \\
\hline & & & & 98 & $26-50$ years & \\
\hline & & & & 72 & $16-25$ years & \\
\hline & & & & 42 & $10-15$ years & \\
\hline & & & & 12 & $1-9$ years & \\
\hline & & & & 0 & $<1$ year & \\
\hline & $\begin{array}{l}\text { ECONOMIC } \\
\text { (10) }\end{array}$ & & & & & \\
\hline \multirow[t]{7}{*}{15.} & & \multirow{7}{*}{$\begin{array}{l}\text { E1: Total } \\
\text { Purchase Cost of } \\
\text { PV Panels to } \\
\text { Utility }\end{array}$} & \multirow{7}{*}{$\begin{array}{l}\text { In volume purchase the current price of } \\
\text { crystalline silicon-based PV panels is about } \\
\$ 1-2 / W(2012) \text {. }\end{array}$} & \multicolumn{3}{|c|}{ Compared to the current average commercial PV panel cost } \\
\hline & & & & $\begin{array}{l}\text { Desirab. } \\
\text { Value }\end{array}$ & $\begin{array}{l}\text { Criterion } \\
\text { Measure }\end{array}$ & $\begin{array}{l}\text { Criterion Measure Description } \\
\text { (if Needed) }\end{array}$ \\
\hline & & & & 100 & $<25 \%$ & \\
\hline & & & & 81 & $26-50 \%$ & \\
\hline & & & & 69 & $51-75 \%$ & \\
\hline & & & & 46 & $76-100 \%$ & \\
\hline & & & & 11 & $101-200 \%$ & \\
\hline
\end{tabular}




\begin{tabular}{|c|c|c|c|c|c|}
\hline & & & 0 & $>200 \%$ & \\
\hline \multirow[t]{10}{*}{16.} & \multirow{10}{*}{$\begin{array}{l}\text { E2: Warranty/ } \\
\text { Maintenance } \\
\text { Cost }\end{array}$} & \multirow{10}{*}{$\begin{array}{l}\text { Warranty may vary from } 10 \text { to } 25 \text { years } \\
\text { with varying performance levels. To } \\
\text { maintain the systems at peak performance } \\
\text { level the utility needs in-house or } \\
\text { contracted maintenance. }\end{array}$} & \multicolumn{3}{|c|}{$\begin{array}{l}\text { Warranty/Maintenance as percent of the volume purchase cost of } \\
\text { the PV panels }\end{array}$} \\
\hline & & & $\begin{array}{l}\text { Desirab. } \\
\text { Value }\end{array}$ & $\begin{array}{l}\text { Criterion } \\
\text { Measure }\end{array}$ & $\begin{array}{l}\text { Criterion Measure Description } \\
\text { (if Needed) }\end{array}$ \\
\hline & & & 100 & $<0.1 \%$ & \\
\hline & & & 90 & $0.1-1 \%$ & \\
\hline & & & 73 & $1-5 \%$ & \\
\hline & & & 46 & $5-10 \%$ & \\
\hline & & & 25 & $10-15 \%$ & \\
\hline & & & 6 & $15-25 \%$ & \\
\hline & & & 0 & $25-50 \%$ & \\
\hline & & & 0 & $>50 \%$ & \\
\hline \multirow[t]{8}{*}{17.} & \multirow{8}{*}{$\begin{array}{l}\text { E3: Total } \\
\text { Associated } \\
\text { Inverter and } \\
\text { Balance-of- } \\
\text { System Purchase } \\
\text { Cost }\end{array}$} & \multirow{8}{*}{$\begin{array}{l}\text { The Balance-of-System (BOS) includes } \\
\text { everything beyond the PV module for a } \\
\text { solar system such as the inverter(s) (or } \\
\text { micro-inverters), the electrical system, and } \\
\text { the structural system for mounting. In } \\
\text { volume purchase the current price of } \\
\text { crystalline silicon-based PV BOS is about } \\
\$ 1.5-3 / W(2012) \text {. }\end{array}$} & \multicolumn{3}{|c|}{ Compared to the current average commercial PV panel BOS cost } \\
\hline & & & $\begin{array}{l}\text { Desirab. } \\
\text { Value }\end{array}$ & $\begin{array}{l}\text { Criterion } \\
\text { Measure }\end{array}$ & $\begin{array}{l}\text { Criterion Measure Description } \\
\text { (if Needed) }\end{array}$ \\
\hline & & & 100 & $<25 \%$ & \\
\hline & & & 84 & $26-50 \%$ & \\
\hline & & & 68 & $51-75 \%$ & \\
\hline & & & 48 & $76-100 \%$ & \\
\hline & & & 16 & $101-200 \%$ & \\
\hline & & & 0 & $>200 \%$ & \\
\hline \multirow[t]{3}{*}{18.} & \multirow[t]{3}{*}{ E4: Disposal Cost } & \multirow{3}{*}{$\begin{array}{l}\text { This is the disposal cost at end of life of a } \\
\text { PV panel. A typical silicon-based PV panel } \\
\text { cost of disposal is estimated to be about } \\
\$ 0.60 \text { for a } 200 W \text { panel. }\end{array}$} & \multicolumn{3}{|c|}{$\begin{array}{l}\text { Compared to the current average commercial PV panel disposal } \\
\text { cost }\end{array}$} \\
\hline & & & $\begin{array}{l}\text { Desirab. } \\
\text { Value }\end{array}$ & $\begin{array}{l}\text { Criterion } \\
\text { Measure }\end{array}$ & $\begin{array}{l}\text { Criterion Measure Description } \\
\text { (if Needed) }\end{array}$ \\
\hline & & & 100 & $<0.25 \%$ & \\
\hline
\end{tabular}




\begin{tabular}{|c|c|c|c|c|c|}
\hline & & & 65 & $0.26-0.50 \%$ & \\
\hline & & & 53 & $0.51-0.75 \%$ & \\
\hline & & & 29 & $0.76-1 \%$ & \\
\hline & & & 10 & $1-2 \%$ & \\
\hline & & & 0 & $2-3 \%$ & \\
\hline & & & 0 & $>3 \%$ & \\
\hline 19. & E5: Levelized & The levelized cost of electricity (LCOE) is & & & \\
\hline & $\begin{array}{l}\text { Cost of } \\
\text { Electricity (LCOE) }\end{array}$ & $\begin{array}{l}\text { considered the most important metric for } \\
\text { renewable energy utility systems. It is also }\end{array}$ & $\begin{array}{l}\text { Desirab. } \\
\text { Value }\end{array}$ & $\begin{array}{l}\text { Criterion } \\
\text { Measure }\end{array}$ & $\begin{array}{l}\text { Criterion Measure Description } \\
\text { (if Needed) }\end{array}$ \\
\hline & & referred to as "levelized cost of energy." & 96 & $<\$ 0.05 / \mathrm{kWh}$ & \\
\hline & & LCOE is the price at which electricity must & 91 & $\begin{array}{l}\$ 0.05- \\
0.10 / \mathrm{kWh}\end{array}$ & \\
\hline & & break even over the utility system lifetime. & 76 & $\begin{array}{l}\$ 0.11- \\
0.15 / \mathrm{kWh}\end{array}$ & \\
\hline & & $\begin{array}{l}\text { It typically Includes all the lifetıme } \\
\text { investment costs, capitals costs, operations }\end{array}$ & 53 & $\begin{array}{l}\$ 0.16- \\
0.20 / \mathrm{kWh}\end{array}$ & \\
\hline & & & 28 & $\begin{array}{l}\$ 0.21- \\
0.25 / \mathrm{kWh}\end{array}$ & \\
\hline & & $\begin{array}{l}\$ 0.10 / \mathrm{kWh} \text { unsubsidized becomes cheaper } \\
\text { than retail electricity in many U.S. markets. }\end{array}$ & 9 & $\begin{array}{l}\$ 0.26- \\
0.30 / \mathrm{kWh}\end{array}$ & \\
\hline & & $\begin{array}{l}\text { Currently LCOE varies greatly and may } \\
\text { range from } \$ 0.15 / \mathrm{kWh} \text { to higher values. }\end{array}$ & 3 & $\begin{array}{l}\$ 0.31- \\
0.35 / \mathrm{kWh}\end{array}$ & \\
\hline & & & 0 & $\begin{array}{l}\$ 0.36- \\
0.40 / \mathrm{kWh}\end{array}$ & \\
\hline & & & 0 & $\begin{array}{l}\$ 0.41- \\
0.45 / \mathrm{kWh}\end{array}$ & \\
\hline & & & 0 & $\begin{array}{l}\$ 0.46- \\
0.50 / \mathrm{kWh}\end{array}$ & \\
\hline & & & 0 & $>\$ 0.50 / \mathrm{kWh}$ & \\
\hline
\end{tabular}




\begin{tabular}{|c|c|c|c|c|c|}
\hline \multirow[t]{13}{*}{20.} & \multirow{13}{*}{$\begin{array}{l}\text { E6: Return on } \\
\text { Investment }\end{array}$} & \multirow{13}{*}{$\begin{array}{l}\text { Lifetime return on investment based on } \\
\text { internal rate of return (IRR). }\end{array}$} & \multicolumn{3}{|c|}{ Internal rate of return (IRR) } \\
\hline & & & $\begin{array}{l}\text { Desirab. } \\
\text { Value }\end{array}$ & $\begin{array}{l}\text { Criterion } \\
\text { Measure }\end{array}$ & $\begin{array}{l}\text { Criterion Measure Description } \\
\text { (if Needed) }\end{array}$ \\
\hline & & & 100 & $>50 \%$ & \\
\hline & & & 99 & $46-50 \%$ & \\
\hline & & & 98 & $41-45 \%$ & \\
\hline & & & 95 & $36-40 \%$ & \\
\hline & & & 91 & $31-35 \%$ & \\
\hline & & & 86 & $26-30 \%$ & \\
\hline & & & 80 & $21-25 \%$ & \\
\hline & & & 69 & $16-20 \%$ & \\
\hline & & & 51 & $11-15 \%$ & \\
\hline & & & 24 & $5-10 \%$ & \\
\hline & & & 0 & $<5 \%$ & \\
\hline \multirow[t]{11}{*}{21.} & \multirow[t]{11}{*}{ E7: Cost of Risk } & \multirow{11}{*}{$\begin{array}{l}\text { The cost of risk in using PV system as } \\
\text { electric utility. Risk may include cost of } \\
\text { downtime/maintenance and the cleanup } \\
\text { of negative environmental impact during } \\
\text { operations such as leakage of hazardous } \\
\text { materials. }\end{array}$} & \multicolumn{3}{|c|}{ Percent of the volume purchase cost of the PV panels } \\
\hline & & & $\begin{array}{l}\text { Desirab. } \\
\text { Value }\end{array}$ & $\begin{array}{l}\text { Criterion } \\
\text { Measure }\end{array}$ & $\begin{array}{l}\text { Criterion Measure Description } \\
\text { (if Needed) }\end{array}$ \\
\hline & & & 100 & $<10 \%$ & \\
\hline & & & 74 & $10-20 \%$ & \\
\hline & & & 36 & $21-30 \%$ & \\
\hline & & & 18 & $31-40 \%$ & \\
\hline & & & 11 & $41-50 \%$ & \\
\hline & & & 4 & $51-100 \%$ & \\
\hline & & & 0 & $101-200 \%$ & \\
\hline & & & 0 & $201-300 \%$ & \\
\hline & & & 0 & $>300 \%$ & \\
\hline
\end{tabular}




\begin{tabular}{|c|c|c|c|c|c|}
\hline \multirow[t]{7}{*}{22.} & \multirow{7}{*}{$\begin{array}{l}\text { E8: Supply Chain } \\
\text { Maturity }\end{array}$} & \multirow{7}{*}{$\begin{array}{l}\text { Distribution and Supply Chain is important } \\
\text { for the buyer of PV panels and associated } \\
\text { balance of systems. The maturity levels of } \\
\text { the supply chain may vary from "ad hoc" } \\
\text { where practices are unstructured to } \\
\text { "extended" where multiple firms compete } \\
\text { for business. } \\
\text { The following defines the supply chain } \\
\text { levels: } \\
\text { - Extended - Firms at the extended level } \\
\text { have multiple supply chains competing } \\
\text { for the business and working together } \\
\text { with a customer focus. This is the } \\
\text { highest level of supply chain maturity. } \\
\text { - Integrated - At this level supply chain } \\
\text { management systems are integrated } \\
\text { and well defined. Production planning } \\
\text { and forecasting are established. } \\
\text { Established firms are typically at this } \\
\text { level. } \\
\text { Linked - The linked level sets the } \\
\text { supply chain on a strategic path by } \\
\text { enabling stronger relationships } \\
\text { between partners and defined } \\
\text { structures and roles. } \\
\text { Defined - At this level firms are } \\
\text { developing supply chain supply chain } \\
\text { relationships and have management } \\
\text { processes. Supply chain performance, } \\
\text { management costs, and customer } \\
\text { satisfaction is improving. However, lack } \\
\text { of integration makes cooperation }\end{array}$} & \multicolumn{3}{|c|}{ Supply chain maturity levels } \\
\hline & & & $\begin{array}{l}\text { Desirab. } \\
\text { Value }\end{array}$ & $\begin{array}{l}\text { Criterion } \\
\text { Measure }\end{array}$ & $\begin{array}{l}\text { Criterion Measure Description } \\
\text { (if Needed) }\end{array}$ \\
\hline & & & 100 & Extended & $\begin{array}{l}\text { Firms at the extended level have } \\
\text { multiple supply chains } \\
\text { competing for the business and } \\
\text { working together with a } \\
\text { customer focus. This is the } \\
\text { highest level of supply chain } \\
\text { maturity. }\end{array}$ \\
\hline & & & 89 & Integrated & $\begin{array}{l}\text { At this level supply chain } \\
\text { management systems are } \\
\text { integrated and well defined. } \\
\text { Production planning and } \\
\text { forecasting are established. } \\
\text { Established firms are typically at } \\
\text { this level. }\end{array}$ \\
\hline & & & 66 & Linked & $\begin{array}{l}\text { The linked level sets the supply } \\
\text { chain on a strategic path by } \\
\text { enabling stronger relationships } \\
\text { between partners and defined } \\
\text { structures and roles. }\end{array}$ \\
\hline & & & 30 & Defined & $\begin{array}{l}\text { At this level firms are developing } \\
\text { supply chain supply chain } \\
\text { relationships and have } \\
\text { management processes. Supply } \\
\text { chain performance, } \\
\text { management costs, and } \\
\text { customer satisfaction is } \\
\text { improving. However, lack of } \\
\text { integration makes cooperation } \\
\text { between supply chain members } \\
\text { difficult. }\end{array}$ \\
\hline & & & 0 & Ad Hoc & $\begin{array}{l}\text { The ad hoc level or stage is } \\
\text { usually associated with start-ups }\end{array}$ \\
\hline
\end{tabular}




\begin{tabular}{|c|c|c|c|c|c|}
\hline & & $\begin{array}{l}\text { between supply chain members } \\
\text { difficult. } \\
\text { - Ad Hoc - The ad hoc level or stage is } \\
\text { usually associated with start-ups with } \\
\text { unstructured management practices } \\
\text { and no measurement processes } \\
\text { established. This typically results in } \\
\text { unpredictable supply chain }\end{array}$ & & & $\begin{array}{l}\text { with unstructured management } \\
\text { practices and no measurement } \\
\text { processes established. This } \\
\text { typically results in unpredictable } \\
\text { supply chain performance, } \\
\text { higher management costs, and } \\
\text { low customer satisfaction. This is } \\
\text { the lowest level of supply chain } \\
\text { maturity. }\end{array}$ \\
\hline & & $\begin{array}{l}\text { costs, and low customer satisfaction. } \\
\text { This is the lowest level of supply chain } \\
\text { maturity. }\end{array}$ & & & \\
\hline \multirow[t]{7}{*}{23.} & \multirow{7}{*}{$\begin{array}{l}\text { E9: Global } \\
\text { Production/ } \\
\text { Supply Volume }\end{array}$} & \multirow{7}{*}{$\begin{array}{l}\text { Global production volume can affect price, } \\
\text { supply, and timely replacement of PV } \\
\text { panels and systems. }\end{array}$} & & & \\
\hline & & & $\begin{array}{l}\text { Desirab. } \\
\text { Value }\end{array}$ & $\begin{array}{l}\text { Criterion } \\
\text { Measure }\end{array}$ & $\begin{array}{l}\text { Criterion Measure Description } \\
\text { (if Needed) }\end{array}$ \\
\hline & & & 100 & $\begin{array}{l}\text { Supply exceeds } \\
\text { demand }\end{array}$ & \\
\hline & & & 88 & $\begin{array}{l}\text { Supply meets } \\
\text { demand }\end{array}$ & \\
\hline & & & 20 & $\begin{array}{l}\text { Supply is less } \\
\text { than demand }\end{array}$ & \\
\hline & & & 5 & $\begin{array}{l}\text { Supply is } \\
\text { diminishing }\end{array}$ & \\
\hline & & & 0 & $\begin{array}{l}\text { There is no } \\
\text { supply }\end{array}$ & \\
\hline \multirow[t]{4}{*}{24.} & \multirow{4}{*}{$\begin{array}{l}\text { E10: Use of Rare } \\
\text { Elements (e.g. } \\
\text { Indium, } \\
\text { Tellurium) }\end{array}$} & \multirow{4}{*}{$\begin{array}{l}\text { Using rare element materials may be an } \\
\text { issue due to their scarcity and restrictive } \\
\text { access. }\end{array}$} & & & \\
\hline & & & $\begin{array}{l}\text { Desirab. } \\
\text { Value }\end{array}$ & $\begin{array}{l}\text { Criterion } \\
\text { Measure }\end{array}$ & $\begin{array}{l}\text { Criterion Measure Description } \\
\text { (if Needed) }\end{array}$ \\
\hline & & & 100 & $\begin{array}{l}\text { No rare } \\
\text { materials are } \\
\text { used }\end{array}$ & \\
\hline & & & 91 & Rare materials & \\
\hline
\end{tabular}




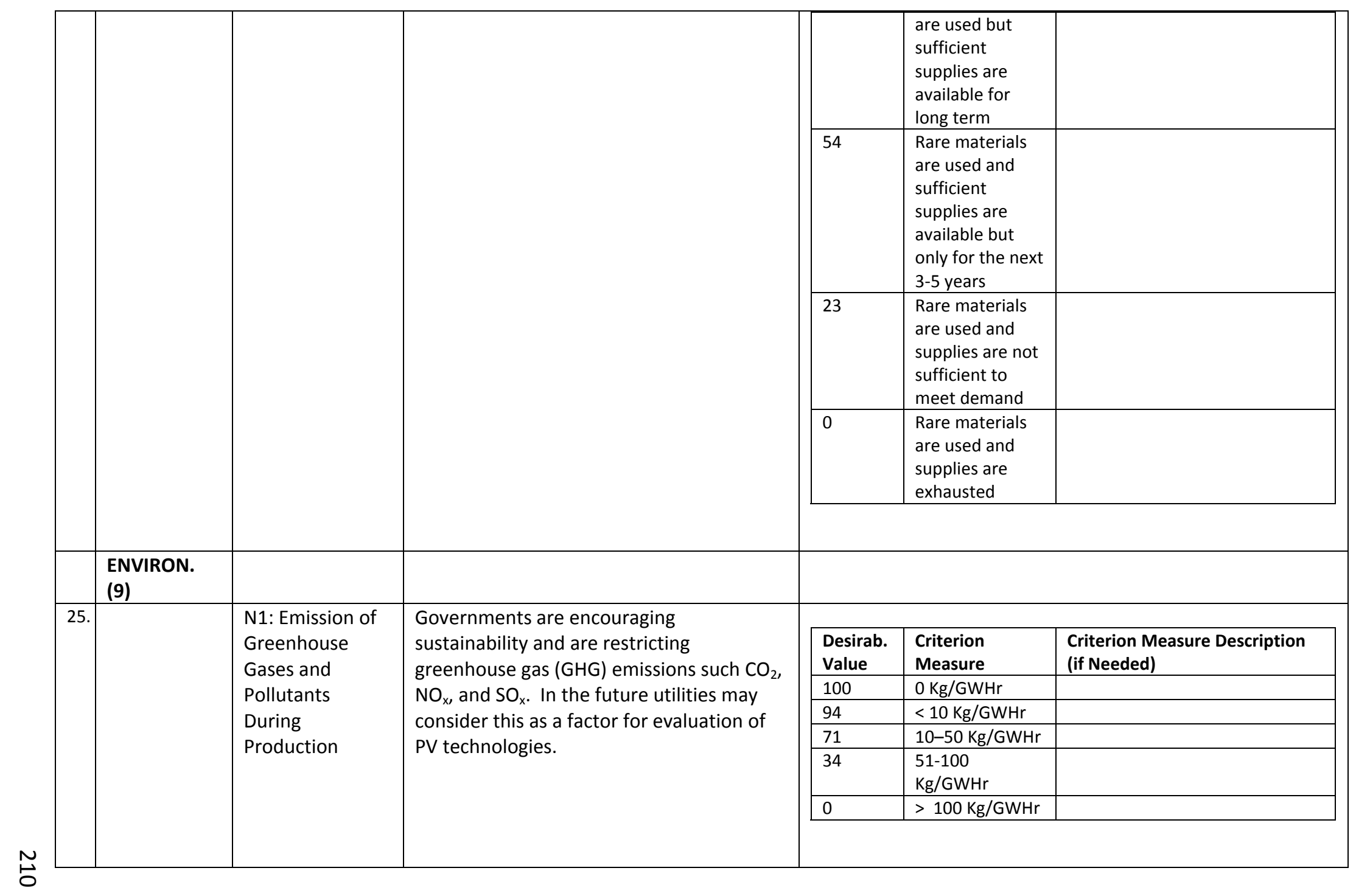




\begin{tabular}{|c|c|c|c|c|c|}
\hline \multirow[t]{6}{*}{26.} & \multirow[t]{6}{*}{$\begin{array}{l}\text { N2: Negative } \\
\text { Ecological } \\
\text { Footprint }\end{array}$} & \multirow{6}{*}{$\begin{array}{l}\text { How much of a negative impact does the } \\
\text { deployment of a PV technology have on } \\
\text { the underlying and surrounding crops, } \\
\text { woods, etc.? }\end{array}$} & $\begin{array}{l}\text { Desirab. } \\
\text { Value }\end{array}$ & $\begin{array}{l}\text { Criterion } \\
\text { Measure }\end{array}$ & $\begin{array}{l}\text { Criterion Measure Description } \\
\text { (if Needed) }\end{array}$ \\
\hline & & & 100 & None & $\begin{array}{l}\text { The PV technology has no } \\
\text { negative impact on the } \\
\text { underlying and surrounding } \\
\text { crops, woods, water, etc. }\end{array}$ \\
\hline & & & 89 & Low & $\begin{array}{l}\text { The PV technology has a } \\
\text { negative impact on the } \\
\text { underlying and surrounding } \\
\text { crops, woods, water, etc., but } \\
\text { corrective measures and } \\
\text { workarounds can eliminate the } \\
\text { effect. }\end{array}$ \\
\hline & & & 44 & Medium & $\begin{array}{l}\text { The PV technology has a } \\
\text { negative impact on the } \\
\text { underlying and surrounding } \\
\text { crops, woods, water, etc., but } \\
\text { corrective measures and } \\
\text { workarounds can reduce the } \\
\text { effect to acceptable levels during } \\
\text { deployment. }\end{array}$ \\
\hline & & & 8 & High & $\begin{array}{l}\text { The PV technology has a } \\
\text { negative impact on the } \\
\text { underlying and surrounding } \\
\text { crops, woods, water, etc., but } \\
\text { even corrective measures and } \\
\text { workarounds may take multiple } \\
\text { years after deployment to } \\
\text { alleviate the effect to acceptable } \\
\text { levels. }\end{array}$ \\
\hline & & & 0 & Very high & $\begin{array}{l}\text { The PV technology has } \\
\text { unacceptable negative impact on } \\
\text { the underlying and surrounding } \\
\text { crops, woods, water, etc. and no } \\
\text { corrective measure can alleviate } \\
\text { the effect. }\end{array}$ \\
\hline
\end{tabular}




\begin{tabular}{|c|c|c|c|c|c|}
\hline \multirow[t]{7}{*}{27.} & \multirow{7}{*}{$\begin{array}{l}\text { N3: Use of } \\
\text { Available Land }\end{array}$} & \multirow{7}{*}{$\begin{array}{l}\text { In many parts of the world land is a scarce } \\
\text { resource and better utilization by a PV } \\
\text { technology is a consideration. A } \\
\text { combination of PV module power density } \\
\text { and adherence to buildings or landscape } \\
\text { geometries need to be considered for } \\
\text { efficient use of available terrain. } \\
\text { For example a thin-film PV technology with } \\
\text { power density of } 100 \mathrm{~W} / \mathrm{m}^{2} \text { is only half as } \\
\text { efficient in land use as a crystalline silicone } \\
\text { (c-Si) PV technology with } 200 \mathrm{~W} / \mathrm{m}^{2} \text {. This is } \\
\text { because twice the area is needed for the } \\
\text { thin-film PV. }\end{array}$} & & & \\
\hline & & & $\begin{array}{l}\text { Desirab. } \\
\text { Value }\end{array}$ & $\begin{array}{l}\text { Criterion } \\
\text { Measure }\end{array}$ & $\begin{array}{l}\text { Criterion Measure Description } \\
\text { (if Needed) }\end{array}$ \\
\hline & & & 100 & Ultra-efficient & $\begin{array}{l}\text { All the available land can be } \\
\text { used by this PV technology at } \\
\text { the equivalent best commercial } \\
\text { PV power density. }\end{array}$ \\
\hline & & & 95 & Highly efficient & $\begin{array}{l}80 \% \text { of the available land can be } \\
\text { used by this PV technology at } \\
\text { the equivalent best power } \\
\text { density. }\end{array}$ \\
\hline & & & 63 & $\begin{array}{l}\text { Medium } \\
\text { efficient }\end{array}$ & $\begin{array}{l}60 \% \text { of the available land can be } \\
\text { used by this PV technology at } \\
\text { the equivalent best power } \\
\text { density. }\end{array}$ \\
\hline & & & 15 & Inefficient & $\begin{array}{l}40 \% \text { of the available land can be } \\
\text { used by this PV technology at } \\
\text { the equivalent best power } \\
\text { density. }\end{array}$ \\
\hline & & & 0 & Very Inefficient & $\begin{array}{l}20 \% \text { of the available land can be } \\
\text { used by this PV technology at } \\
\text { the equivalent best power } \\
\text { density. }\end{array}$ \\
\hline \multirow[t]{4}{*}{28.} & \multirow{4}{*}{$\begin{array}{l}\text { N4: Use of } \\
\text { Hazardous } \\
\text { Materials (e.g. } \\
\text { Cadmium) }\end{array}$} & \multirow{4}{*}{$\begin{array}{l}\text { Using hazardous materials may be an issue } \\
\text { if there is accidental leakage or contact } \\
\text { with humans or animals. }\end{array}$} & & & \\
\hline & & & $\begin{array}{l}\text { Desirab. } \\
\text { Value }\end{array}$ & $\begin{array}{l}\text { Criterion } \\
\text { Measure }\end{array}$ & $\begin{array}{l}\text { Criterion Measure Description } \\
\text { (if Needed) }\end{array}$ \\
\hline & & & 100 & $\begin{array}{l}\text { No hazardous } \\
\text { materials are } \\
\text { used }\end{array}$ & \\
\hline & & & 86 & $\begin{array}{l}\text { Hazardous } \\
\text { materials are } \\
\text { used but } \\
\text { quantity is }\end{array}$ & \\
\hline
\end{tabular}




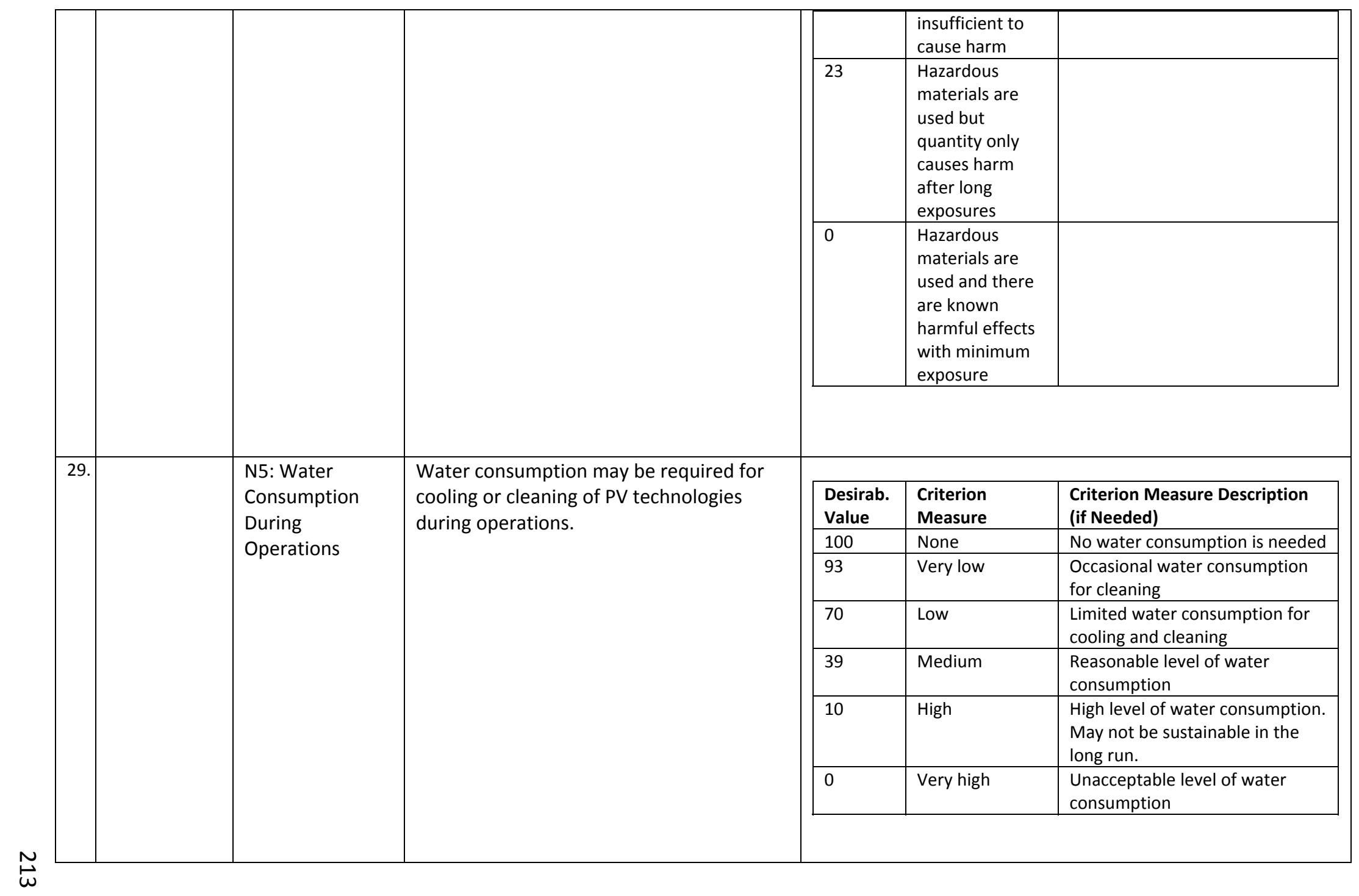




\begin{tabular}{|c|c|c|c|c|c|}
\hline \multirow[t]{7}{*}{30.} & \multirow{8}{*}{$\begin{array}{l}\text { N6: } \\
\text { Consumption of } \\
\text { Other Materials } \\
\text { During } \\
\text { Operations }\end{array}$} & \multirow{8}{*}{$\begin{array}{l}\text { Materials in addition to water such as } \\
\text { panel cleaning solvents, protective panel } \\
\text { coatings, and herbicides may be consumed } \\
\text { during operations. }\end{array}$} & $\begin{array}{l}\text { Desirab. } \\
\text { Value }\end{array}$ & $\begin{array}{l}\text { Criterion } \\
\text { Measure }\end{array}$ & $\begin{array}{l}\text { Criterion Measure Description } \\
\text { (if Needed) }\end{array}$ \\
\hline & & & 100 & None & $\begin{array}{l}\text { No additional materials-such as } \\
\text { panel cleaning solvents, } \\
\text { protective panel coatings, and } \\
\text { herbicides - are consumed } \\
\text { during operations. }\end{array}$ \\
\hline & & & 91 & Very low & $\begin{array}{l}\text { Occasionally additional } \\
\text { materials - such as panel } \\
\text { cleaning solvents, protective } \\
\text { panel coatings, and herbicides- } \\
\text { are consumed during operations. }\end{array}$ \\
\hline & & & 69 & Low & $\begin{array}{l}\text { Limited amounts of materials- } \\
\text { such as panel cleaning solvents, } \\
\text { protective panel coatings, and } \\
\text { herbicides -are consumed } \\
\text { during operations. }\end{array}$ \\
\hline & & & 36 & Medium & $\begin{array}{l}\text { Reasonable amounts of } \\
\text { materials - such as panel } \\
\text { cleaning solvents, protective } \\
\text { panel coatings, and herbicides- } \\
\text { are consumed during operations. }\end{array}$ \\
\hline & & & 11 & High & $\begin{array}{l}\text { High amounts of materials-such } \\
\text { as panel cleaning solvents, } \\
\text { protective panel coatings, and } \\
\text { herbicides -are consumed } \\
\text { during operations. May not be } \\
\text { sustainable in the long run. }\end{array}$ \\
\hline & & & 0 & Very high & $\begin{array}{l}\text { Unacceptable amounts of } \\
\text { additional materials - such as } \\
\text { panel cleaning solvents, } \\
\text { protective panel coatings, and } \\
\text { herbicides - are consumed } \\
\text { during operations. }\end{array}$ \\
\hline & & & & & \\
\hline
\end{tabular}




\begin{tabular}{|c|c|c|c|c|c|}
\hline \multirow[t]{9}{*}{31.} & \multirow{9}{*}{$\begin{array}{l}\text { N7: Recyclability } \\
\text { at End-of-Life }\end{array}$} & \multirow{9}{*}{$\begin{array}{l}\text { Disposal of PV systems at the end-of-life } \\
\text { are more attractive if the component } \\
\text { materials can be easily recycled. }\end{array}$} & \multicolumn{3}{|c|}{ Level of recyclability } \\
\hline & & & $\begin{array}{l}\text { Desirab. } \\
\text { Value }\end{array}$ & $\begin{array}{l}\text { Criterion } \\
\text { Measure } \\
\end{array}$ & $\begin{array}{l}\text { Criterion Measure Description } \\
\text { (if Needed) }\end{array}$ \\
\hline & & & 100 & Complete & $\begin{array}{l}\text { All the components of this PV } \\
\text { module can be recycled. }\end{array}$ \\
\hline & & & 94 & Very high & $\begin{array}{l}80 \% \text { of the components of this } \\
\text { PV module can be recycled. }\end{array}$ \\
\hline & & & 80 & High & $\begin{array}{l}60 \% \text { of the components of this } \\
\text { PV module can be recycled. }\end{array}$ \\
\hline & & & 56 & Medium & $\begin{array}{l}40 \% \text { of the components of this } \\
\text { PV module can be recycled. }\end{array}$ \\
\hline & & & 29 & Low & $\begin{array}{l}20 \% \text { of the components of this } \\
\text { PV module can be recycled. }\end{array}$ \\
\hline & & & 8 & Very low & $\begin{array}{l}10 \% \text { of the components of this } \\
\text { PV module can be recycled. }\end{array}$ \\
\hline & & & 0 & None & $\begin{array}{l}\text { None of components of this PV } \\
\text { module can be recycled. }\end{array}$ \\
\hline \multirow[t]{6}{*}{32.} & \multirow{6}{*}{$\begin{array}{l}\text { N8: Waste } \\
\text { Chemicals at } \\
\text { End-of-Life }\end{array}$} & \multirow[t]{6}{*}{$\begin{array}{l}\text { Waste chemicals may be released by the } \\
\text { disposal of PV systems. }\end{array}$} & \multicolumn{3}{|c|}{ Amount of waste chemicals } \\
\hline & & & $\begin{array}{l}\text { Desirab. } \\
\text { Value }\end{array}$ & $\begin{array}{l}\text { Criterion } \\
\text { Measure }\end{array}$ & $\begin{array}{l}\text { Criterion Measure Description } \\
\text { (if Needed) }\end{array}$ \\
\hline & & & 100 & None & $\begin{array}{l}\text { No waste chemicals are released } \\
\text { by the disposal of this PV } \\
\text { system. }\end{array}$ \\
\hline & & & 93 & Very Low & $\begin{array}{l}\text { Negligible amounts of waste } \\
\text { chemicals are released by the } \\
\text { disposal of this PV system. }\end{array}$ \\
\hline & & & 69 & Low & $\begin{array}{l}\text { Low amounts of waste chemicals } \\
\text { are released by the disposal of } \\
\text { this PV system and require } \\
\text { nominal storage and disposal. }\end{array}$ \\
\hline & & & 29 & Medium & $\begin{array}{l}\text { The waste chemicals released by } \\
\text { the disposal of this PV system } \\
\text { require special storage and }\end{array}$ \\
\hline
\end{tabular}




\begin{tabular}{|c|c|c|c|c|c|}
\hline & & & & & disposal. \\
\hline & & & 10 & High & $\begin{array}{l}\text { High amounts of waste } \\
\text { chemicals are released by the } \\
\text { disposal of this PV system. } \\
\text { Storage and disposal may } \\
\text { become unfeasible. }\end{array}$ \\
\hline & & & 0 & Very high & $\begin{array}{l}\text { Unacceptable amounts of waste } \\
\text { chemicals are released by the } \\
\text { disposal of PV systems. }\end{array}$ \\
\hline \multirow[t]{8}{*}{33.} & \multirow{8}{*}{$\begin{array}{l}\text { N9: Waste Gases } \\
\text { at End-of-Life }\end{array}$} & \multirow{8}{*}{$\begin{array}{l}\text { Waste gases may be released by the } \\
\text { disposal of PV systems. }\end{array}$} & \multicolumn{3}{|c|}{ Amount of waste gases } \\
\hline & & & \begin{tabular}{|l|} 
Desirab. \\
Value \\
\end{tabular} & $\begin{array}{l}\text { Criterion } \\
\text { Measure }\end{array}$ & $\begin{array}{l}\text { Criterion Measure Description } \\
\text { (if Needed) }\end{array}$ \\
\hline & & & 100 & None & $\begin{array}{l}\text { No waste gases are released by } \\
\text { the disposal of this PV system. }\end{array}$ \\
\hline & & & 93 & Very Low & $\begin{array}{l}\text { Negligible amounts of waste } \\
\text { gases are released by the } \\
\text { disposal of this PV system. }\end{array}$ \\
\hline & & & 69 & Low & $\begin{array}{l}\text { Low amounts of waste gases are } \\
\text { released by the disposal of this } \\
\text { PV system and require nominal } \\
\text { storage and disposal. }\end{array}$ \\
\hline & & & 34 & Medium & $\begin{array}{l}\text { The waste gases released by the } \\
\text { disposal of this PV system } \\
\text { require special storage and } \\
\text { disposal. }\end{array}$ \\
\hline & & & 11 & High & $\begin{array}{l}\text { High amounts of waste gases are } \\
\text { released by the disposal of this } \\
\text { PV system. Storage and disposal } \\
\text { may become unfeasible. }\end{array}$ \\
\hline & & & 0 & Very high & $\begin{array}{l}\text { Unacceptable amounts of waste } \\
\text { gases are released by the } \\
\text { disposal of PV systems. }\end{array}$ \\
\hline
\end{tabular}




\begin{tabular}{|c|c|c|c|c|c|c|}
\hline & & & & & & \\
\hline & $\begin{array}{l}\text { POLITICAL } \\
\text { (6) }\end{array}$ & & & & & \\
\hline \multirow[t]{8}{*}{34.} & \multirow{8}{*}{ (6) } & \multirow{8}{*}{$\begin{array}{l}\text { P1: National } \\
\text { Priority }\end{array}$} & \multirow{8}{*}{$\begin{array}{l}\text { National importance of the PV technology } \\
\text { under consideration }\end{array}$} & \multirow{3}{*}{$\begin{array}{l}\begin{array}{l}\text { Desirab. } \\
\text { Value }\end{array} \\
100\end{array}$} & & \\
\hline & & & & & $\begin{array}{l}\text { Criterion } \\
\text { Measure }\end{array}$ & $\begin{array}{l}\text { Criterion Measure Description } \\
\text { (if Needed) }\end{array}$ \\
\hline & & & & & $\begin{array}{l}\text { Very high } \\
\text { priority }\end{array}$ & $\begin{array}{l}\text { This PV technology has been } \\
\text { placed on a top national priority } \\
\text { and fully supported with } \\
\text { government funds for R\&D and } \\
\text { deployment. }\end{array}$ \\
\hline & & & & 89 & High priority & $\begin{array}{l}\text { This PV technology has been } \\
\text { placed on a national priority and } \\
\text { programs are in place to support } \\
\text { its deployment. }\end{array}$ \\
\hline & & & & 56 & Medium priority & $\begin{array}{l}\text { This PV technology has been } \\
\text { placed on a national priority } \\
\text { along with competing PV } \\
\text { technologies. }\end{array}$ \\
\hline & & & & 25 & Low priority & $\begin{array}{l}\text { The government has indicated } \\
\text { an interest in this PV technology } \\
\text { but has not placed it on any } \\
\text { priority. }\end{array}$ \\
\hline & & & & 9 & Very low priority & $\begin{array}{l}\text { The government may evaluate } \\
\text { the importance of this PV } \\
\text { technology in the future. }\end{array}$ \\
\hline & & & & 0 & No priority & $\begin{array}{l}\text { The government is not aware of } \\
\text { this technology and is neutral } \\
\text { about the support for it. }\end{array}$ \\
\hline
\end{tabular}




\begin{tabular}{|c|c|c|c|c|c|}
\hline \multirow[t]{6}{*}{35.} & \multirow[t]{6}{*}{$\begin{array}{l}\text { P2: Government } \\
\text { Incentives }\end{array}$} & \multirow[t]{6}{*}{$\begin{array}{l}\text { Government support through financing, } \\
\text { tariffs, and other incentives and } \\
\text { preferences can affect the selection of a PV } \\
\text { technology. }\end{array}$} & $\begin{array}{l}\text { Desirab. } \\
\text { Value }\end{array}$ & $\begin{array}{l}\text { Criterion } \\
\text { Measure }\end{array}$ & $\begin{array}{l}\text { Criterion Measure Description } \\
\text { (if Needed) }\end{array}$ \\
\hline & & & 100 & $\begin{array}{l}\text { Very strong } \\
\text { support }\end{array}$ & $\begin{array}{l}\text { The government provides very } \\
\text { strong financing, incentives, and } \\
\text { tariffs in support of this PV } \\
\text { technology. }\end{array}$ \\
\hline & & & 90 & Strong support & $\begin{array}{l}\text { The government provides strong } \\
\text { financing, incentives, and tariffs } \\
\text { in support of this PV technology. }\end{array}$ \\
\hline & & & 66 & $\begin{array}{l}\text { Medium } \\
\text { support }\end{array}$ & $\begin{array}{l}\text { The government provides } \\
\text { financing, incentives, and tariffs } \\
\text { for this PV technology, but has } \\
\text { restrictions. }\end{array}$ \\
\hline & & & 30 & Low support & $\begin{array}{l}\text { The government provides } \\
\text { nominal financing, incentives, } \\
\text { and tariffs for this PV } \\
\text { technology. }\end{array}$ \\
\hline & & & 0 & No support & $\begin{array}{l}\text { The government provides no } \\
\text { financing, incentives, or tariffs } \\
\text { for the PV technology. }\end{array}$ \\
\hline \multirow[t]{4}{*}{36.} & \multirow{4}{*}{$\begin{array}{l}\text { P3: Regulatory } \\
\text { Risk }\end{array}$} & \multirow{4}{*}{$\begin{array}{l}\text { Regulatory hurdles or risks associated with } \\
\text { permitting requirements. }\end{array}$} & \multicolumn{3}{|c|}{ Level of regulatory risk } \\
\hline & & & $\begin{array}{l}\text { Desirab. } \\
\text { Value }\end{array}$ & $\begin{array}{l}\text { Criterion } \\
\text { Measure }\end{array}$ & $\begin{array}{l}\text { Criterion Measure Description } \\
\text { (if Needed) }\end{array}$ \\
\hline & & & 100 & None & $\begin{array}{l}\text { There is no regulatory risk to } \\
\text { deploy this PV technology. }\end{array}$ \\
\hline & & & 93 & Low & $\begin{array}{l}\text { The regulatory hurdles to deploy } \\
\text { this PV technology are low and }\end{array}$ \\
\hline
\end{tabular}




\begin{tabular}{|c|c|c|c|c|c|}
\hline & & & & & $\begin{array}{l}\text { with little effort can be } \\
\text { overcome. }\end{array}$ \\
\hline & & & 33 & Medium & $\begin{array}{l}\text { The regulatory hurdles may } \\
\text { cause extra work and expenses } \\
\text { to deploy this PV technology, but } \\
\text { they can be overcome in the } \\
\text { long run. }\end{array}$ \\
\hline & & & 16 & High & $\begin{array}{l}\text { The regulatory hurdles are high } \\
\text { and may make the deployment } \\
\text { of this } \mathrm{PV} \text { technology unfeasible } \\
\text { in the long run. }\end{array}$ \\
\hline & & & 0 & Unacceptable & $\begin{array}{l}\text { Regulations make it } \\
\text { unacceptable to deploy the PV } \\
\text { technology. }\end{array}$ \\
\hline 37. & P4: Relations & Support or opposition by local politicians. & & & \\
\hline & $\begin{array}{l}\text { with Local } \\
\text { Politicians }\end{array}$ & & $\begin{array}{l}\text { Desirab. } \\
\text { Value }\end{array}$ & $\begin{array}{l}\text { Criterion } \\
\text { Measure }\end{array}$ & $\begin{array}{l}\text { Criterion Measure Description } \\
\text { (if Needed) }\end{array}$ \\
\hline & & & 100 & Strong support & $\begin{array}{l}\text { Local politicians support the } \\
\text { deployment of this PV } \\
\text { technology unconditionally. }\end{array}$ \\
\hline & & & 89 & $\begin{array}{l}\text { Medium } \\
\text { support }\end{array}$ & $\begin{array}{l}\text { Local politicians have shown } \\
\text { some support but have also } \\
\text { expressed some concerns about } \\
\text { the deployment of this PV } \\
\text { technology. }\end{array}$ \\
\hline & & & 63 & No support & $\begin{array}{l}\text { Local politicians do not support } \\
\text { the deployment of this PV } \\
\text { technology. }\end{array}$ \\
\hline & & & 16 & $\begin{array}{l}\text { Medium } \\
\text { opposition }\end{array}$ & $\begin{array}{l}\text { Local politicians have expressed } \\
\text { some opposition to the } \\
\text { deployment of this PV } \\
\text { technology. }\end{array}$ \\
\hline & & & 0 & $\begin{array}{l}\text { Strong } \\
\text { opposition }\end{array}$ & $\begin{array}{l}\text { Local politicians oppose the } \\
\text { deployment of this PV } \\
\text { technology. }\end{array}$ \\
\hline
\end{tabular}




\begin{tabular}{|c|c|c|c|c|c|}
\hline \multirow[t]{9}{*}{38.} & \multirow{9}{*}{$\begin{array}{l}\text { P5: Local } \\
\text { Sourcing }\end{array}$} & \multirow{9}{*}{$\begin{array}{l}\text { If the PV technology uses local sourcing it } \\
\text { could increase the local or regional } \\
\text { support. For example, Canada requires } \\
\text { partial local sourcing of renewable energy } \\
\text { equipment for feed-in tariffs to be } \\
\text { applicable. }\end{array}$} & \multicolumn{3}{|c|}{ Level of local sourcing } \\
\hline & & & $\begin{array}{l}\text { Desirab. } \\
\text { Value }\end{array}$ & $\begin{array}{l}\text { Criterion } \\
\text { Measure }\end{array}$ & $\begin{array}{l}\text { Criterion Measure Description } \\
\text { (if Needed) }\end{array}$ \\
\hline & & & 100 & Complete & $\begin{array}{l}\text { All the components of this PV } \\
\text { module are sourced locally. }\end{array}$ \\
\hline & & & 91 & Very high & $\begin{array}{l}80 \% \text { of the components of this } \\
\text { PV module are sourced locally. }\end{array}$ \\
\hline & & & 84 & High & $\begin{array}{l}60 \% \text { of the components of this } \\
\text { PV module are sourced locally. }\end{array}$ \\
\hline & & & 74 & Medium & $\begin{array}{l}40 \% \text { of the components of this } \\
\text { PV module are sourced locally. }\end{array}$ \\
\hline & & & 43 & Low & $\begin{array}{l}20 \% \text { of the components of this } \\
\text { PV module are sourced locally. }\end{array}$ \\
\hline & & & 24 & Very low & $\begin{array}{l}10 \% \text { of the components of this } \\
\text { PV module are sourced locally. }\end{array}$ \\
\hline & & & 0 & None & $\begin{array}{l}\text { None of the components of this } \\
\text { PV module are sourced locally. }\end{array}$ \\
\hline \multirow[t]{5}{*}{39.} & \multirow{5}{*}{$\begin{array}{l}\text { P6: Conformance } \\
\text { to Existing } \\
\text { Political, Legal, } \\
\text { Management } \\
\text { Constructs by } \\
\text { Utilities }\end{array}$} & \multirow{5}{*}{$\begin{array}{l}\text { Utilities are accustomed to established } \\
\text { business or regulatory practices and } \\
\text { change is difficult. }\end{array}$} & \multicolumn{3}{|c|}{ Conformance to regulations familiar to the Utility } \\
\hline & & & $\begin{array}{l}\text { Desirab. } \\
\text { Value }\end{array}$ & $\begin{array}{l}\text { Criterion } \\
\text { Measure }\end{array}$ & $\begin{array}{l}\text { Criterion Measure Description } \\
\text { (if Needed) }\end{array}$ \\
\hline & & & 100 & $\begin{array}{l}\text { Utility does not } \\
\text { need to change } \\
\text { its current } \\
\text { practices }\end{array}$ & \\
\hline & & & 86 & $\begin{array}{l}\text { Utility has to } \\
\text { make minor } \\
\text { changes to its } \\
\text { current } \\
\text { practices }\end{array}$ & \\
\hline & & & 30 & $\begin{array}{l}\text { Utility has to } \\
\text { make major }\end{array}$ & \\
\hline
\end{tabular}




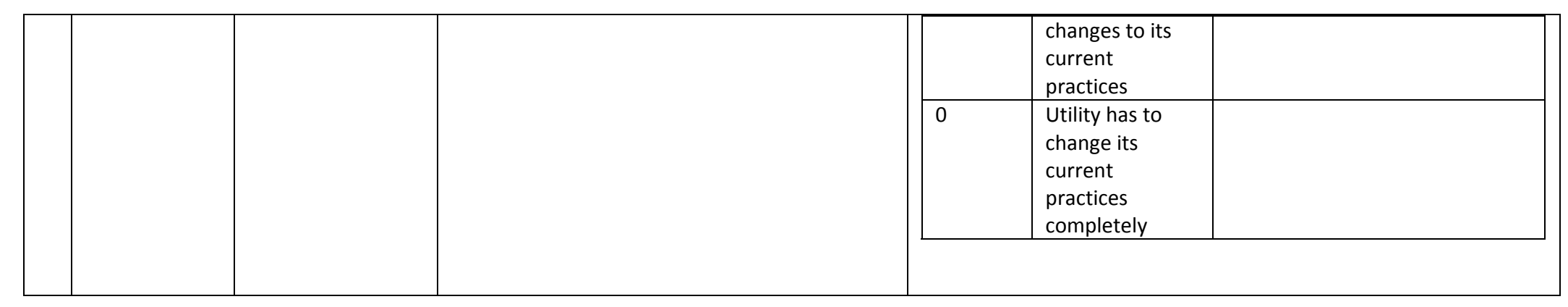

